\author{
UNIVERSIDADE DE SÃO PAULO \\ FACULDADE DE FILOSOFIA, LETRAS E CIÊNCIAS HUMANAS \\ DEPARTAMENTO DE HISTÓRIA \\ PROGRAMA DE PÓS-GRADUAÇÃO EM HISTÓRIA SOCIAL
}

\title{
Artífices do Próspero Mundo Novo: colonos, migrantes e imigrantes em São Paulo e no Pará (1868-1889)
}

Jonas Marçal de Queiroz

Orientador: Prof ${ }^{a} \operatorname{Dr}^{a}$ Mary Del Priore

São Paulo, 2005 


\author{
UNIVERSIDADE DE SÃO PAULO \\ FACULDADE DE FILOSOFIA, LETRAS E CIÊNCIAS HUMANAS \\ DEPARTAMENTO DE HISTÓRIA \\ PROGRAMA DE PÓS-GRADUAÇÃO EM HISTÓRIA SOCIAL
}

\title{
Artífices do Próspero Mundo Novo: colonos, migrantes e imigrantes em São Paulo e no Pará (1868-1889)
}

Jonas Marçal de Queiroz

Tese apresentada ao Programa de Pós-Graduação em História Social, do Departamento de História da Faculdade de Filosofia, Letras e Ciências Humanas da Universidade de São Paulo, para obtenção do título de Doutor em História.

Orientador: Prof ${ }^{a} \mathrm{Dr}^{\mathrm{a}}$ Mary Del Priore

São Paulo, 2005 


\section{AGRADECIMENTOS}

Esta tese começou a ser concebida quando ainda estávamos cursando o mestrado na Universidade Estadual de Campinas. Ao compulsarmos fontes produzidas no século XIX, chamou-nos a atenção as imagens produzidas acerca dos trabalhadores e, em particular, dos imigrantes europeus. Dadas as poucas - e em geral fracassadas experiências dos fazendeiros paulistas com trabalhadores imigrantes, surpreenderamnos a projeção de imagens - em geral positivas - sobre o trabalhador que - na concepção de muitos - deveria substituir o escravo nas lavouras. Em 1997, surgiu-nos a oportunidade de trabalhar como professor visitante na Universidade Federal do Pará. Imediatamente veio-nos a idéia de conhecer melhor a chamada "transumância amazônica”, expressão utilizada por Celso Furtado para se referir ao movimento migratório de nordestinos em direção à Amazônia. Iniciamos, assim, um estudo comparado entre processos históricos ocorridos nas duas regiões, o qual, anos mais tarde, transformamos no projeto de doutorado.

A recepção que tivemos na Universidade Federal do Pará não poderia ter sido melhor. Além do acolhimento dos professores e alunos do curso de História, contamos com o apoio inestimável da Pró-Reitoria de Pesquisa e Pós-Graduação, que nos possibilitou contar com a ajuda de estudantes de Iniciação Científica. Abisague de Araújo Dias, Helder Lameira de Lima e Sulamita Gabriele R. do Carmo prestaram grande ajuda na coleta da documentação. Os funcionários do CENTUR, Arquivo Público do Pará, Arquivo da Comissão Demarcadora de Limites e da Biblioteca do Instituto Emílio Goeldi e da Biblioteca Central da Universidade Federal do Pará sempre souberam, como poucos, aliar profissionalismo, atenção e solicitude. Nas salas de aulas de Belém, Castanhal, Breves, Soure, Altamira e Marabá pudemos conhecer um pouco da difícil realidade da Amazônia, mas também da luta de seu povo e da confiança na História como uma possibilidade de conhecimento da realidade, passo importante para sua transformação.

Ainda na Universidade Federal do Pará, fizemos parte de um grupo de pesquisadores que nos ampliou as oportunidades de convívio e de troca de experiência profissional. Juntamente com Cláudia Füller, Nírvea Ravena, Flávio dos Santos Gomes, Mauro Cezar Coelho e Rosa Elisabeth Acevedo Marin realizamos eventos, pesquisas e 
publicações, sempre com o apoio da própria Universidade e do Conselho Nacional de Pesquisas - CNPq. O Projeto Integrado "Trabalhadores e Sociedades Agrárias no GrãoPará: rupturas nos séculos XVIII e XIX" nos trouxe não apenas crescimento intelectual e profissional, mas principalmente amizades sólidas, que combinam respeito, amizade e solidariedade. Flávio dos Santos Gomes e Mauro Cezar Coelho, especialmente, têm sido interlocutores e colaboradores em novas iniciativas de pesquisa e publicações.

A estadia na Amazônia, que inicialmente estava prevista para durar dois anos, estendeu-se por mais alguns. Em 1998 passamos a trabalhar na Universidade Federal do Amapá, o que nos permitiu dar continuidade ao trabalho que vínhamos desenvolvendo. O apoio e incentivo dos professores do curso de História e de outros cursos, com os quais convivemos, foi mais uma vez fundamental. Sidney da Silva Lobato e Tatiana Pantoja Oliveira, bolsistas de Iniciação Científica do $\mathrm{CNPq}$, nos prestaram grande auxílio na análise da documentação. A convivência com os alunos, tanto da graduação em História como do Curso de Especialização em História e Historiografia da Amazônia nos proporcinou acréscimos importantes em nossa formação e na pesquisa que vínhamos desenvolvendo. A Pró-Reitoria de Pesquisa da Universidade Federal do Amapá e a CAPES também nos deram apoio inestimável, fornecendo, em 2002, uma bolsa PICDT para a realização do doutorado.

A transformação da pesquisa inicial em projeto de doutorado se tornou possível quando Mary Del Piore concordou em nos orientar. Convidada a participar do Curso de Especialização que ali coordenávamos, Mary nos brindou com seu profissionalismo, gentilezas e conhecimentos. A partir de então, suas críticas sempre procedentes e motivadoras, suas palavras de incentivo nos momentos de dificuldades, seu apoio e confiança se tornaram imprescindíveis.

Em maio de 2002, uma nova mudança, desta vez para a Universidade Federal de Viçosa. Antes disso, passamos alguns meses entre Campinas e São Paulo, realizando pesquisas e cursando disciplina do Programa de Doutorado da USP. As aulas do professor Elias Thomé Saliba nos ajudaram a definir melhor o tema e a tese. Em Campinas, a amizade e a ajuda, mais uma vez, do Artur, Jeferson, Marcos, Pedro, Ivone e Cláudio foram fundamentais.

Durante o Exame de Qualificação, contamos com críticas e sugestões valiosas dos professores Flávio dos Santos Gomes e Henrique Soares Carneiro, as quais 
procuramos seguir dentro de nossas limitações. Os funcionários da Secretaria de História e da Secretaria Geral de Pós-Graduação, sempre com muita gentileza, prestaram grande ajuda providenciando papéis e informações. Ao Programa de PósGraduação em História Social devemos a oportunidade de realizar mais este acréscimo em nossa formação.

Em Viçosa, a Pró-Reitoria de Pesquisa e Pós-Graduação, em conjunto com o CNPq e a FAPEMIG, também contribuíram muito com as sempre providenciais bolsas de Iniciação Científica concedidas a Ana Paula Ribeiro Freitas, Ícaro Trindade Carvalho, Giovane José da Silva e Walkíria M. de Freitas Martin. Também tive o apoio de Priscila Vieira Matos e de Fernanda Abreu Nagem, todos estudantes do curso de História, que dividiram conosco a realização deste trabalho. A eles e aos demais estudantes da UFV um muito obrigado.

A adaptação em Viçosa não teria sido possível sem o apoio fraterno do Daniel e da Patrícia, sem o sorriso da Natália, que chegou recentemente. O Jarbas e a Vilma, meus outros irmãos, meus pais, Otaviano e Dazia, mesmo distantes, não pouparam incentivos. Na UFV, a France Coelho e o Paulo Toma deram estímulo e apoio nas questões acadêmicas. A Izabel, Fábio e Vânia, Mauro e Wilma, Flávio e Regina foram amigos e amigas em todas as horas. Um muitíssimo obrigado a todos!

A passagem pela Amazônia nos trouxe muito mais do que este trabalho, acréscimos profissionais e novas amizades. Desde Belém, Karla tem sido esposa, companheira inseparável em todas as horas e em todos os lugares, enfim, um verdadeiro Norte! 


\section{RESUMO}

Nosso objeto de estudo é o processo de reorganização do mercado de trabalho, durante as últimas décadas da escravidão, em São Paulo e no Pará. Através da análise dos relatórios dos presidentes de província e de artigos publicados em jornais, principalmente, procuramos interpretar a formulação de representações acerca do trabalhador imigrante. Argumentamos que estas imagens não dizem respeito apenas a seus referentes imediatos, ou seja, os trabalhadores estrangeiros, que os grupos dominantes desejavam como substitutos para os escravos, mas também aos próprios trabalhadores aqui existentes, cativos ou não. Através de um jogo de imagens, invertendo qualidades e defeitos que atribuíam à força de trabalho existente no país, jornalistas e administradores de província não estavam aludindo a um trabalhador real, mas construindo representações que guardavam relações com as dificuldades que os proprietários rurais enfrentavam para conseguir uma força de trabalho numerosa, disciplina e dependente. Em termos historiográficos, corroboramos uma tendência verificada nas produções mais recentes, que concebem a existência de um pacto político entre as elites dirigentes do Governo Imperial e as elites regionais, e não uma subordinação destas por aquelas. A comparação entre semelhanças e especificidades das duas províncias pesquisadas evidenciou que os grupos envolvidos na produção agroexportadora procuravam conseguir a adesão de setores mais amplos ao seu projeto político. Ao investirem na idéia da properidade futura da nação, condicionando-a ao desenvolvimento da agricultura de exportação, tentavam evitar que propostas alternativas de desenvolvimento fossem gestadas, prejudicando seus interesses. 


\section{ABSTRACT}

Our object of study is the process of rearrangement of the work market, during the last decades of the slavery, in São Paulo and Pará provinces. Through the analysis of two kinds of sources, like Presidents of Provinces' reports to the assembly and several articles published in local periodicals - in São Paulo and Pará - we studied the construction of representations concerning immigrant worker. We argue that these images were not only related to the foreign workers, which were wanted by dominant groups of society as substitute for the slave-workers. In according to our analysis, those representations were also related to Brazilians workers, captives or not. Through a game of images, inverting qualities and defects that they attributed to the work force existed in the country, journalists and administrators of provinces made up the image of an ideal worker that kept relations with the difficulties that the agricultural proprietors faced to obtain a numerous force of work, disciplined and dependent. In History terms we corroborate a trend verified in the recent productions which conceive the existence of a politician pact between the elite controllers of the Imperial Government and the local elites, and not a subordination of these for those. The comparison between similarities and specificities of the two provinces evidenced that the groups involved in the agroexporter production looked for to obtain the adhesion of great sectors to its politics projects. Those groups invested in the idea of the prosper future of the nation, conditioning that idea to the development to the exportation of agriculture products to prevent that other alternatives proposals to the development of the country gained force, harming its interests. 


\section{ÍNDICE}

$\begin{array}{ll}\text { Introdução } & 10\end{array}$

Capítulo I - Males do Presente e Esperança do Futuro 39

1.1 Amazônia: inferno e paraíso $\quad 39$

$\begin{array}{ll}\text { 1.2 Café: o fiel da balança } & 57\end{array}$

$\begin{array}{ll}1.3 \text { O preço da prosperidade } & 79\end{array}$

Capítulo II - Soluções Improváveis $\quad 83$

2.1 A escravidão dissimulada $r$

2.2 O índio: "civilização" e extermínio 101

$\begin{array}{ll}2.3 \text { Trabalho e progresso } & 124\end{array}$

Capítulo III - Perdidos no "Deserto" $\quad 129$

3.1 A salvação da lavoura 131

3.2 Insatisfeitos 142

$\begin{array}{ll}3.3 \text { De onde virá a solução? } & 149\end{array}$

$\begin{array}{ll}3.4 \text { Conflitos regionais } & 165\end{array}$

$\begin{array}{ll}3.5 \mathrm{O} \text { duro choque da realidade } & 170\end{array}$

Capítulo IV - Estranhos no Novo Mundo 173

$\begin{array}{lr}\text { 4.1 A difícil convivência } & 173\end{array}$

4.2 A opção conservadora $\quad 179$

$\begin{array}{ll}4.3 \text { A outra face da moeda } & 192\end{array}$

4.4 Unindo esforços 205

4.5 Críticas à colonização oficial 215

$\begin{array}{ll}\text { 4.6 De imigrante a trabalhador } & 220\end{array}$

$\begin{array}{ll}\text { Conclusão } & 222\end{array}$

$\begin{array}{ll}\text { Fontes } & 229\end{array}$

$\begin{array}{ll}\text { Bibliografia citada } & 242\end{array}$ 
"Nossos incessantes e supremos esforços devem convergir para o desenvolvimento da colonização e imigração: só elas salvarão a agricultura, desviando a tempestade, que está iminente" (Sebastião José Pereira Relatório à Assembléia. Legislativa. Provincial de S. Paulo)

Oh! Que milagre! Que soberbas criaturas aqui vieram! Como os homens são belos! Admirável mundo novo que tem tais habitantes! (W. Shakespeare - $A$ Tempestade)

"Oh! Infeliz Invasor! Fadejas desenraizado, descontente, praguejando, mas fertilizas... Por ti sou denegrida; que importa! Impassível, porém, aguardo as gerações, que hão de seguir, cantando, o carro de meu triunfo!" (Alberto Rangel - Inferno Verde) 


\section{INTRODUÇÃO}

A historiografia brasileira relativa às últimas décadas da escravidão conferiu destaque para as relações entre abolicionismo e imigrantismo. Para alguns autores, o imigrantismo foi causa do abolicionismo, enquanto outros argumentaram o contrário, ou seja, que o abolicionismo estimulou o imigrantismo. Há também aqueles que afirmaram terem sido ambos, abolicionismo e imigrantismo, etapas de um processo mais amplo de liquidação das heranças coloniais e de adequação do país ao modo capitalista de produção. Nos últimos anos, porém, surgiu uma nova interpretação, qual seja a de que ambos - abolicionismo e imigrantismo - resultaram das pressões exercidas pelos escravos sobre fazendeiros e políticos.

De acordo com Emília Viotti da Costa, por exemplo, a partir de meados do século XIX, a interrupção do tráfico transatlântico de escravos e a falta de fontes alternativas de suprimento de braços no próprio país fizeram com que cafeicultores paulistas começassem a importar imigrantes europeus, abrindo caminho para a substituição do trabalho escravo pelo trabalho livre. ${ }^{1}$ Ao mesmo tempo, melhorias no sistema de transporte e no processo de beneficiamento do café aumentavam a capacidade produtiva das lavouras, o que, por um lado, requeria trabalhadores mais especializados e, por outro, permitia um uso mais eficiente dos mesmos. Nessas condições, o trabalhador livre se revelaria tão ou mais adequado do que o escravo, mas desde que fosse possível consegui-lo regularmente e a baixo custo. Outro fator que reforçava a tendência à substituição do escravo pelo trabalhador livre era a dinamização da economia, com a crescente circulação do capital e a ampliação do mercado interno, pois, diante das novas oportunidades de investimentos, os fazendeiros não desejavam mais imobilizar capitais com a aquisição de uma mão-de-obra, cujos preços estavam cada vez mais altos. $^{2}$

\footnotetext{
${ }^{1}$ COSTA, Emília Viotti da. Da Senzala à Colônia. 3a . ed. São Paulo: Brasiliense, 1989. p. 111. Publicado pela primeira vez em 1966, o livro foi reeditado várias vezes sem que a autora fizesse alterações no texto. No prefácio da segunda edição (1982), em que fez um balanço da produção surgida após a primeira edição, ela afirmou que considerava o esquema geral da interpretação ainda válido.

${ }^{2}$ Ibidem. p. 181-212.
} 
Porém, apenas os proprietários que abriam fazendas nas áreas pioneiras e que não dispunham de grandes plantéis de escravos teriam se interessado pela imigração européia. Aqueles das áreas mais antigas, principalmente do Vale do Paraíba, onerados por dívidas e às voltas com a queda de produtividade de suas lavouras, continuavam apegados aos métodos rotineiros e, portanto, ao trabalho escravo. ${ }^{3}$ Além das transformações econômicas, o descontentamento de grupos sociais emergentes em relação ao monopólio do poder pelas oligarquias tradicionais, assim como conflitos internos a elas, contribuíram para que propostas reformistas ganhassem a adesão de setores mais amplos, principalmente nas áreas urbanas. Entre estes grupos estavam os que desejavam promover a imigração européia e os que não dependiam da mão-de-obra escrava, que, por esse motivo, instigavam o protesto dos escravizados, transformando a abolição numa questão política. ${ }^{4}$

Da mesma forma, Paula Beiguelman concluiu que desde meados do século XIX a economia já dava sinais de que estava propensa a criar padrões novos de riqueza e a diferenciar-se internamente no sentido da incorporação de um trabalhadorconsumidor. Além de utilizar o braço escravo apenas para as funções essenciais da lavoura e estimular a incipiente urbanização, alguns fazendeiros empregavam excedentes de capital na valorização da terra e criavam colônias de imigrantes voltadas, também, para a agricultura de alimentação. ${ }^{5}$

Entretanto, diferentemente da regionalização adotada por Emília Viotti da Costa, Paula Beiguelman concluiu que apenas os fazendeiros do extremo Oeste paulista desejavam dificultar a entrada de mais escravos na Província e favorecer a imigração européia, enfrentando a resistência dos proprietários do Oeste antigo, que ainda se abasteciam de escravos, e dos legisladores do Norte e Nordeste, regiões exportadoras potenciais dessa mão-de-obra. Diante desta situação, os representantes do Oeste novo se aliaram aos do Vale do Paraíba, na Assembléia Provincial de São Paulo, para fechar o

\footnotetext{
${ }^{3}$ Ibidem. p. 235-244.

${ }^{4}$ Ibidem. p. 450-457.

${ }^{5}$ BEIGUELMAN, Paula. A Formação do Povo no Complexo Cafeeiro. Aspectos políticos. 2a . ed. São Paulo: Pioneira, 1977. A primeira edição do livro é de 1968, que foi revista e ampliada para a segunda edição.
} 
mercado regional de escravos e, assim, fazer com que projetos voltados para a imigração subvencionada fossem aprovados. ${ }^{6}$

Além de Emília Viotti da Costa e Paula Beiguelman, inclusive antes delas, vários autores que consideraram o imigrantismo como causa do abolicionismo estabeleceram diferenciações regionais entre os proprietários rurais de São Paulo, incluindo, muitas vezes, nessas caracterizações os do Norte e Nordeste. Em 1960, por exemplo, Fernando Henrique Cardoso afirmou que o fato de a produção cafeeira do Oeste Paulista ter ganhado impulso no período posterior ao fim do tráfico negreiro quando o preço do escravo tornou-se excessivamente alto - fez com que o fazendeiro daquela região passasse a importar mão-de-obra livre, tornando-se, até, abolicionista. Em vez de comprar escravos, alugava a força de trabalho de homens livres, sem necessitar do uso da violência - como haviam feito seus antecessores capitalistas europeus - para libertar os trabalhadores dos meios de produção que possuíam, pois já os importava juridicamente livres da posse de meios e instrumentos de trabalho. ${ }^{7}$

Outros autores, porém, ainda que adotassem, em linhas gerais, estas interpretações, não estabeleceram, claramente, relações de causa e efeito entre imigrantismo e abolicionismo, nem consideraram a passagem da escravidão ao trabalho livre um processo direto. É o caso de José de Souza Martins, ${ }^{8}$ para quem o futuro inevitável da escravidão e as condições peculiares de participação da força de trabalho na agricultura de exportação levaram à formulação da política imigrantista. Em trabalho posterior, o autor enfatizou que a mentalidade dos fazendeiros tinha raízes sociais definidas, expressando a forma de capital que estava na base do seu empreendimento, e

\footnotetext{
${ }^{6}$ Ibidem. p. 34-35. Na diferenciação regional estabelecida pela autora, o extremo Oeste paulista seria a região de Ribeirão Preto e o Oeste antigo, a de Campinas. Isto por volta da década de 1870. A maioria dos autores que estabeleceram uma regionalização das áreas cafeeiras no século XIX, referiram-se apenas ao Oeste Paulista e Vale do Paraíba. Paula Beiguelman afirmou que atribuir aos fazendeiros do Vale do Paraíba o epíteto de "emperrados" é repetir a ideologia dos fazendeiros do Oeste Paulista. O que deve ser levado em conta, segundo ela, são as condições estruturais que impeliram a lavoura da área mais nova a se diferenciar.

7 CARDOSO, Fernando Henrique. Condições sociais da industrialização de São Paulo. Revista Brasiliense, São Paulo, 28: 31-46, mar./abr. 1960. p. 35. Apesar de algumas diferenças de interpretação, autores como Octavio Ianni e Florestan Fernandes também consideraram a propensão dos fazendeiros do Oeste paulista a adotar o trabalhado livre como um fator decisivo no encaminhamento político da abolição da escravatura. Há um balanço dessa produção em EISENBERG, Peter. A mentalidade dos fazendeiros no Congresso Agrícola de 1878. In: LAPA, José Roberto do Amaral (org.). Modos de Produção e Realidade Brasileira. Petrópolis: Vozes, 1980. p. 167-194.

${ }^{8} \mathrm{O}$ autor citou um trecho do livro de Emília Viotti da Costa, no qual esta autora afirma apenas que a emancipação da escravatura e a imigração estavam intimamente relacionadas. MARTINS, José de Souza. A Imigração e a Crise do Brasil Agrário. São Paulo: Pioneira, 1973. p. 50.
} 
que, portanto, a incorporação do trabalho livre não alterou profundamente o vínculo entre empregadores e trabalhadores. ${ }^{9} \mathrm{O}$ que transparece nesta conclusão é que não havia, da parte dos cafeicultores, uma propensão a empregar o trabalho livre como forma de racionalizar a produção e, desta forma, maximizar lucros.

Não obstante as especificidades das análises, os autores consideraram que as pressões britânicas contra o tráfico negreiro, que culminaram com a sua extinção definitiva, por volta de 1850, desempenharam o papel de fator desencadeador do processo de substituição do escravo pelo imigrante europeu em São Paulo. Isto porque o receio da escassez de braços teria estimulado a procura de fontes alternativas de suprimento de mão-de-obra, sobretudo fontes estáveis, de baixo custo e que garantissem a continuidade da produção e dos lucros por ela proporcionados, mesmo que para isso as condições de trabalho suportadas pelos cativos tivessem de ser modificadas. As pressões sobre o comércio escravista e o trabalho compulsório eram frutos do processo de acumulação capitalista na Europa, para o qual tanto o tráfico negreiro como a plantation contribuíam, desde o período colonial. ${ }^{10}$ Nessa perspectiva, a substituição do trabalho escravo pelo trabalho livre representou uma etapa importante na liquidação do sistema colonial do país, provocando - e ao mesmo tempo sendo o resultado de - uma ampla revisão dos estilos de vida e dos valores da sociedade brasileira. ${ }^{11}$

A partir do final da década de 1960, começaram a surgir novas interpretações, principalmente nos estudos relativos ao período colonial, mas que influenciaram as análises voltadas para a etapa posterior à emancipação política. Jacob Gorender e Ciro Flamarion S. Cardoso, ${ }^{12}$ por exemplo, criticaram a excessiva ênfase da historiografia produzida até então nas relações de comercialização e, conseqüentemente, nos vínculos

\footnotetext{
${ }^{9}$ Para o autor, a escravidão não era apenas uma instituição, mas "uma relação real fundada em condições históricas definidas". A transição do trabalho escravo para o trabalho livre não teria sido o advento de uma classe de trabalhadores assalariados, mas a definição e universalização da propriedade capitalista da terra, o cativeiro da terra, como forma de assegurar a sujeição do trabalho. Tratar-se-ia da instauração de uma nova modalidade de relações não-capitalistas de produção, o sucedâneo da acumulação primitiva de capitais. MARTINS, José de Souza. O Cativeiro da Terra. $4^{\text {a }}$ ed. São Paulo: Hucitec, 1990. p. 61.

${ }_{10}$ É muito clara a influência nas interpretações citadas até aqui da noção de "sentido da colonização" de Caio Prado Júnior, a qual foi ampliada por Fernando Novais, em seu estudo clássico. Outra influência marcante é Eric Williams, cujo livro foi publicado poucos anos depois do de Caio Prado Junior. Ver: PRADO JUNIOR, Caio. Formação do Brasil Contemporâneo. Colônia. $21^{\mathrm{a}}$ ed. São Paulo: Brasiliense, 1989; WILLIAMS, Eric. Capitalismo e Escravidão. Trad. Carlos Nayfeld. Rio de Janeiro: Americana, 1975; NOVAIS, Fernando A. Portugal e Brasil na Crise do Antigo Sistema Colonial (1777-1808). $6^{\mathrm{a}}$. ed. São Paulo: Hucitec, 1995.

${ }^{11}$ COSTA, Emília Viotti da. Op. cit. p. 466.

12 GORENDER, Jacob. O Escravismo Colonial. $3^{\mathrm{a}}$. ed., São Paulo, Ática, 1980; CARDOSO, Ciro Flamarion S. Agricultura, Escravidão e Capitalismo. Petrópolis: Vozes, 1979.
} 
entre a exploração colonial e o processo de acumulação primitiva de capitais. Maria Odila Silva Dias argumentou que a emancipação política do Brasil resultou do enraizamento de interesses portugueses e, principalmente, do processo de interiorização da metrópole na região Centro-Sul da Colônia. ${ }^{13}$ Seguindo estas tendências, Antônio Barros de Castro propôs uma inversão das perspectivas analíticas adotadas e o estudo da conformação interior da sociedade brasileira. ${ }^{14}$

Outros estudiosos, alguns dos quais já vinham realizando pesquisas nesta direção, ampliaram o foco de análise, ${ }^{15}$ anteriormente muito centrado nas relações entre Metrópole e Colônia. Procurou-se, a partir de então, caracterizar e compreender também as dinâmicas internas e as experiências dos atores históricos, em detrimento das estruturas e dos conceitos explicativos, mas sem negar suas relações como o mundo externo. Nesse sentido, vários trabalhos foram publicados sobre a produção agrícola de subsistência e de abastecimento, ${ }^{16}$ as formas de sociabilidade, a miscigenação étnica e cultural, a mentalidade e o imaginário colonial. ${ }^{17}$ A contribuição dos brasilianistas

${ }^{13}$ DIAS, Maria Odila Silva. A interiorização da Metrópole (1808-1853). In: MOTA, Carlos Guilherme (org.). 1822: Dimensões. 2a. ed; São Paulo: Perspectiva, 1986. p. 165.

${ }^{14}$ CASTRO, Antônio Barros de. A Economia Política, o Capitalismo e a Escravidão. In: LAPA, José Roberto do Amaral (org.). Modos de Produção e Realidade Brasileira. Op. cit. p. 67-108.

${ }^{15}$ Veja-se, principalmente, o acirrado debate sobre a questão do mercado interno colonial, que teve vários desdobramentos. Entre os críticos das análises centradas na noção de sentido da colonização, destacamse, além de Ciro Flamarion Cardoso e Jacob Gorender, autores que procuraram enfatizar a importância das relações intra-coloniais e inter-coloniais, como: LAPA, José Roberto do Amaral. A Bahia e a Carreira da Índia. São Paulo: Companhia Editora Nacional, 1968; FRAGOSO, João Luís Ribeiro. Homens de Grossa Aventura. Acumulação e hierarquia na praça mercantil do Rio de Janeiro (1790-1830). $2^{\mathrm{a}}$ ed. Rio de Janeiro: Civilização Brasileira, 1998. ALENCASTRO, Luís Felipe. O Trato dos Viventes. Formação do Brasil no Atlântico Sul. $2^{\mathrm{a}}$ reimp. São Paulo: Companhia das Letras, 2000; FRAGOSO, João; FLORENTINO, Manolo. O Arcaísmo como Projeto. Mercado atlântico, sociedade agrária e elite mercantil em uma economia colonial tardia. Rio de Janeiro, c. 1790 - c. 1840. $4^{\text {a }}$ ed., Rio de Janeiro: Civilização Brasileira. 2001.

${ }^{16}$ Há um balanço dessa produção em: LINHARES, Maria Yedda; SILVA, Francisco Carlos Teixeira da. História da Agricultura Brasileira. Combates e Controvérsias. São Paulo: Brasiliense, 1981. Quanto às análises sobre a agricultura de subsistência e abastecimento, inclusive nos seus desdobramentos políticos, ver: LINHARES, Maria Yedda. História do abastecimento; uma problemática em questão (1530-1918). Brasília: Binagri, 1979. LENHARO, Alcir. As tropas da Moderação. São Paulo: Símbolo, 1979.

${ }^{17}$ São exemplos desta tendência, que se tornou particularmente volumosa nas décadas de 1980 e 1990, os seguintes trabalhos: SOUZA, Laura de Mello e. O Diabo e a Terra de Santa Cruz. Feitiçaria e Religiosidade Popular no Brasil Colonial. São Paulo: Companhia das Letras, 1986. CARNEIRO, Maria Luiz Tucci. Preconceito Racial em Portugal e Brasil Colônia. Os cristãos-novos e o mito da pureza de sangue. $3^{\mathrm{a}}$ ed. São Paulo: Perspectiva, 2005; SOARES, Mariza de Carvalho. Devotos da Cor. Identidade étnica, religiosidade e escravidão no Rio de Janeiro, século XVIII. Rio de Janeiro: Civilização Brasileira, 2000; DEL PRIORE, Mary. Festas e Utopias no Brasil Colonial. São Paulo: Brasiliense, 1994; GOMES, Plínio Freire. Um Herege Vai ao Paraíso. Cosmologia de um ex-colono condenado pela Inquisição (1680-1744). São Paulo: Companhia das Letras, 1997; ABREU, Martha. O Império do Divino. Festas Religiosas e Cultura Popular no Rio de Janeiro, 1830-1900. Rio de Janeiro: Nova Fronteira; São Paulo: Fapesp, 1999. 
também se fazia notar, sobretudo através da utilização de novas fontes documentais, métodos de análises sofisticados e estudos comparativos inovadores entre os sistemas escravistas das Américas. ${ }^{18}$

Entre as interpretações que começaram a ser revistas estavam as que consideravam a presença do escravo um obstáculo à utilização do trabalho livre e ao avanço do processo de racionalização capitalista das unidades produtoras, tendo esta última recebido crítica contundente de Robert Slenes. ${ }^{19}$ Baseando-se, em parte, nos trabalhos deste autor e de Robert Conrad, Jacob Gorender afirmou que os fazendeiros do Oeste Paulista continuaram investindo em escravos até às vésperas da abolição final e só optaram pelo imigrante devido à pressão exercida pelos abolicionistas e pelos escravos. $^{20}$ Assim, para este autor, coube ao abolicionismo desempenhar o papel de "fator dinâmico primordial", tanto na extinção do escravismo como na implementação da política imigratória.

A chamada transição do trabalho escravo para o trabalho livre - expressão que alguns pesquisadores procuraram evitar por entenderem que ela sugeriria a não coexistência entre as duas formas de trabalho - revelava-se, a cada nova pesquisa, um processo lento, gradual e complexo, permeado de contradições, independentemente da região estudada. Com isto, tornou-se cada vez mais difícil o estabelecimento de relações, até certo ponto simplificadoras, de causa e efeito. ${ }^{21}$ Além disso, influenciados

\footnotetext{
${ }^{18}$ Ver, por exemplo: CONRAD, Robert. Os últimos anos da escravatura no Brasil. 1850-1888. Trad. Fernando de Castro Ferro. 2a . ed., Rio de Janeiro: Civilização Brasileira, 1978; EISENBERG, Peter. $O p$. cit.; HALL, Michael M. The origins of mass immigration in Brazil. 1871-1914. Tese de Ph. D., Columbia University, 1969; DEAN, Warren. Rio Claro: um sistema brasileiro de grande lavoura. 1820-1920. Rio de Janeiro: Paz e Terra, 1977; SLENES, Robert. The demography and economics of Brazilian Slavery, 1850-1888. Tese de Ph. D. Standford University, 1976; HOLLOWAY, Thomas H. Imigrantes para $o$ Café. Café e sociedade em São Paulo, 1886-1934. Trad. Eglê Malheiros. Rio de Janeiro: Paz e Terra, 1984; KLEIN, Herbert S. A Escravidão Africana. América Latina e Caribe. Trad. José Eduardo de Mendonça. São Paulo: Brasiliense, 1987; SCHWARTZ, Stuart. Segredos Internos. Engenhos e escravos na sociedade colonial. São Paulo: Companhia das Letras, 1988.

${ }^{19}$ SLENES, Robert W. Grandeza ou Decadência? O mercado de escravos e a economia cafeeira da Província do Rio de Janeiro, 1850-1888. In: COSTA, Iraci del Nero da (org.): Brasil: História Econômica e Demográfica. São Paulo: Instituto de Pesquisas Econômicas (IPE), 1986, p.103-155.

${ }^{20}$ GORENDER, Jacob. Op. cit. 557-572.

${ }^{21}$ Em resposta à crítica de Jacob Gorender Emília Viotti da Costa afirmou que as duas teses imigrantismo como causa do abolicionismo e abolicionismo como causa do imigrantismo - não são necessariamente contraditórias como parecem à primeira vista, pois se a preocupação em introduzir imigrantes nas áreas cafeeiras só ocorreu após a ameaça de proibição do tráfico negreiro, também é verdade que no momento em que se constituiu um grupo de interesses ligados à imigração, este foi levado a reconhecer que a escravidão constituía em um obstáculo à imigração. COSTA, Emília Viotti da. Op. cit. p. $50-51$.
} 
por vertentes historiográficas internacionais, ${ }^{22}$ autores dedicados à análise do passado escravista deixaram de lado os macromodelos conceituais, as análises dicotomizadas, investindo na pesquisa documental para matizar as práticas e representações dos sujeitos históricos nas lutas complexas que empreenderam. ${ }^{23}$ Em razão disso, passaram a enfatizar, cada vez mais, as ações políticas dos atores sociais, e não apenas as formas institucionalizadas de luta. ${ }^{24}$

É o que podemos notar no trabalho de Célia Maria Marinho de Azevedo, que procurou deslocar o eixo do debate sobre a passagem do trabalho escravo para o trabalho livre para o âmbito das lutas entre senhores e escravos. A autora concluiu que a rebeldia dos escravos - e não uma eventual mentalidade progressista dos cafeicultores das áreas pioneiras de São Paulo - forçou os políticos a aprovarem medidas favoráveis ao abolicionismo e ao imigrantismo. ${ }^{25}$ Uma dessas medidas foi a lei que praticamente proibiu a entrada de escravos na Província a partir de 1881, a qual teria sido suscitada pelo medo do "negro mau vindo do Norte". Da mesma forma, a preocupação em

\footnotetext{
${ }^{22}$ Referimo-nos à influência da história das mentalidades e da nova história cultural francesas, da microhistória e de estudos antropológicos como: MINTZ, Sidney. Caribbean Transformations. Chicago: Aldine Publishing Company, 1974; e MINTZ, Sidney; PRICE, Richard. An Anthropological Approach to the Afro-American Past: a Caribbean Perspective. ISHI Occacional Papers in Social Change, $\mathrm{n}^{\circ} .2$, Philadelphia Institute for the Study of Human Issues, 1976. É também marcante a influência do revisionismo marxista, sobretudo dos trabalhos: GENOVESE, Eugente. A Terra Prometida. O mundo que os escravos criaram. Trad. Maria Inês Rolim e Donaldson M. Garschagen. Rio de Janeiro: Paz e Terra, 1988; THOMPSON, E. P. A Formação da Classe Operária Inglesa. Rio de Janeiro: Paz e Terra, 1987. 3 vols.

${ }^{23}$ Entre os estudos que denotam esta preocupação encontramos perspectivas teóricas e metodológicas nem sempre convergentes. A título de exemplo, destacamos: SOUZA, Laura de Melo e. Os Desclassificados do Ouro. Rio de Janeiro: Graal, 1982; MATTOSO, Katia Queirós. Ser Escravo no Brasil. São Paulo: Brasiliense, 1982; DIAS, Maria Odila Leite da Silva. Quotidiano e Poder em São Paulo no Século XIX: Ana Gertrudes de Jesus. São Paulo: Brasiliense, 1984. ALGRANTI, Leila Mezan. O Feitor Ausente: estudos sobre a escravidão urbana. Rio de Janeiro - 1808-1821. Petrópolis: Vozes, 1988. REIS, João José. Rebelião Escrava no Brasil. A história do levante dos malês (1835). São Paulo: Brasiliense, 1986; CHALHOUB, Sidney. Visões da Liberdade. Uma história das últimas décadas da escravidão na corte. São Paulo: Companhia das Letras, 1990; GOMES, Flávio dos Santos. Histórias de Quilombolas. Mocambos e comunidades de senzalas no Rio de Janeiro - século XIX. Rio de Janeiro: Arquivo Nacional, 1995; CASTRO, Hebe Maria Mattos de. Das Cores do Silêncio. Os significados da liberdade no sudeste escravista - Brasil séc. XIX. Rio de Janeiro: Arquivo Nacional, 1995; SLENES, Robert W. Na Senzala, Uma Flor. Esperanças e recordações na formação da família escrava. Brasil sudeste, século XIX. Rio de Janeiro: Nova Fronteira, 1999.

${ }^{24}$ Isto é particularmente notado nos estudos acerca dos quilombos. Primeiramente, foram considerados como uma tentativa dos escravos de preservação da cultura e de sociabilidades africanas; num segundo momento, passaram a ser interpretados como uma forma de negação extremada à ordem escravista. Mais recentemente, os pesquisadores começaram a assinalar as relações entre os quilombos e a sociedade escravista à sua volta, sobretudo no sentido da constituição de um campesinato negro. Para uma análise sobre a questão, ver: REIS, João José e GOMES, Flávio dos Santos (org.). Liberdade Por Um Fio. História dos quilombos no Brasil. São Paulo: Companhia das Letras, 1996.

${ }^{25}$ AZEVEDO, Célia Maria Marinho de. Onda Negra, Medo Branco. O negro no imaginário das elites Século XIX. Rio de Janeiro, Paz e Terra, 1987. p. 159-174.
} 
garantir o controle social, ameaçado pelo aumento do número de crimes e insurreições de escravos, levou os legisladores a subvencionarem a imigração européia e a implementarem algumas medidas destinadas a incorporar os ex-escravos ao mercado de trabalho. $^{26}$

As mudanças operadas na historiografia, durante as últimas décadas do século $\mathrm{XX}$, foram determinadas, também, pela crescente profissionalização do ofício do historiador, decorrente da expansão do ensino superior, do surgimento de novos programas de pós-graduação, instituições de pesquisa, revistas especializadas e eventos acadêmicos. $^{27} \mathrm{~A}$ cada ano, estudos monográficos baseados em análises de fontes documentais ainda não pesquisadas, ou de fontes já conhecidas mas reinterpretadas, mostravam que as análises pioneiras, não obstante sua inegável contribuição, produziram interpretações excessivamente generalizantes.

Em 1983, a Revista Brasileira de História, que entrava em nova fase, publicou um importante estudo de Michael M. Hall e Verena Stolcke sobre a imigração em São Paulo. ${ }^{28}$ Neste artigo, os autores argumentaram que a opção pelo imigrante europeu não decorreu de uma efetiva escassez de braços ou da convicção de que o trabalho livre era mais produtivo em relação ao trabalho escravo, mas da preocupação dos cafeicultores em manter o controle sobre o processo de reorganização do mercado de trabalho. A partir de meados do século XIX, os empregadores experimentaram várias formas de trabalho, como a parceria, a locação de serviços e o colonato, até que conseguissem garantir um controle efetivo sobre seus trabalhadores e, conseqüentemente, margens satisfatórias de lucros. Mas isto só se tornou possível, segundo os autores, devido à ação do governo, subvencionando a imigração em massa e criando mecanismos de controle

\footnotetext{
${ }^{26}$ Embora sem discutir as eventuais conexões entre a rebeldia dos escravos e a política imigrantista, outros autores consideraram de grande importância o recrudescimento das lutas entre senhores e escravos nas últimas décadas da escravidão. Análises semelhantes à de Célia Maria Marinho de Azevedo podem ser encontradas em: CHALHOUB, Sidney. Op. cit.; MACHADO, Maria Helena. O Plano e o Pânico. Os movimentos sociais na década da abolição. Rio de Janeiro: UFRJ; São Paulo: Edusp, 1994.

${ }^{27}$ Há, relativamente, poucos estudos que promovem balanços historiográficos e, menos ainda, sobre o processo de institucionalização do saber histórico no país. Entre as publicações surgidas nas últimas décadas, destacam-se: LAPA, José Roberto do Amaral. História e Historiografia. Brasil pós-64. Rio de Janeiro: Paz e Terra, 1985; FICO, Carlos e POLITO, Ronald. A História no Brasil (1980-1989). Elementos para uma avaliação historiográfica. Ouro Preto: UFOP, 1982. 2 vols.; FREITAS, Marcos Cezar (org.). Historiografia Brasileira em Perspectiva. São Paulo: Contexto, 1998.

${ }^{28}$ STOLCKE, Verena e HALL, Michael M. A introdução do trabalho livre nas fazendas de café de São Paulo. Revista Brasileira de História, São Paulo, 3 (6): 80-120, set. 1983.
} 
dos trabalhos pelos seus empregadores através, por exemplo, da reforma da Lei de Locação de Serviços em 1879.

Como ressaltamos até aqui, a maioria dos pesquisadores que se dedicaram ao estudo do processo de reorganização do mercado de trabalho nas últimas décadas da escravidão concentrou suas análises nas estruturas econômicas ou nas experiências das províncias cafeeiras, principalmente Rio de Janeiro e São Paulo. ${ }^{29}$ As conclusões extraídas a partir delas foram, algumas vezes, projetadas para as demais regiões do país. As atuais regiões Norte e Nordeste, especificamente, quando mencionadas nestas análises, geralmente aparecem como economicamente decadentes e fornecedoras em potencial de mão-de-obra para as mais desenvolvidas ou em vias de crescimento. ${ }^{30}$ São ainda escassos os estudos sobre a abolição antecipada dos escravos das províncias do Ceará e Amazonas, sobre a repercussão de ambos os fenômenos nas províncias vizinhas, sobre os fluxos demográficos e sobre as políticas imigratórias naquela região, não obstante o aumento significativo da produção historiográfica brasileira nas últimas décadas.

Em relação ao Pará, as pesquisas de Vicente Salles acerca da presença do negro, ${ }^{31}$ de Flávio dos Santos Gomes, ${ }^{32}$ a respeito da constituição e interação de comunidades quilombolas com a sociedade escravista, de Rosa Elisabeth Acevedo

\footnotetext{
${ }^{29}$ Não só em relação a este tema mas a vários outros. Como observou Mary Del Priore, boa parte da historiografia brasileira, isolada no Sudeste, produz uma história do Brasil excludente e seletiva, ditada pelos interesses de hegemônicos centros acadêmicos. DEL PRIORE, Mary. Prefácio. In: DEL PRIORE, Mary; GOMES, Flávio (org.). Os Senhores dos Rios. Amazônia, Margens e Histórias. Rio de Janeiro: Elsevier, 2003. p. X. Grifo no original.

${ }^{30}$ Em 1880 e 1881, as províncias de Minas Gerais, Rio de Janeiro e São Paulo criaram taxas que praticamente proibiram a introdução de escravos oriundos de outras regiões. A Lei Saraiva-Cotegipe proibiu a mudança de domicílio de escravos entre províncias, com exceção da transferência de um para outro domícilio do senhor, em casos de obtenção do escravo por herança ou adjudicação forçada, mudança de domicílio do senhor e fuga do escravo. Apesar dessas medidas, estima-se que cerca de 200 mil escravos teriam sido transportados no tráfico interprovincial entre 1850 e 1881 . Segundo Robert Conrad, no mercado de Belém a procura por escravos continuou grande até 1882. CONRAD, Robert. $O p$. cit. p. 220. A estimativa, que é de Robert Slenes, encontra-se em CONRAD, Robert Tumbeiros. O tráfico de escravos para o Brasil. Trad. Elvira Serapicos. São Paulo: Brasiliense, 1985. p. 196.

${ }^{31}$ SALLES, Vicente. O Negro no Pará - Sob o Regime da Escravidão. Rio de Janeiro, Fundação Getúlio Vargas, 1971.

${ }^{32}$ GOMES, Flávio dos Santos. Quilombos, Histórias e as Invenções da Liberdade e do Cativeiro. Cadernos do Centro de Filosofia e Ciências Humanas, Belém, 12 (1-2): 99-140, jan./dez. 1993. GOMES, Flávio dos Santos. Fronteiras e Mocambos: o protesto negro na Guiana Brasileira. In: GOMES, Flávio dos Santos (org.). Nas Terras do Cabo Norte. Fronteiras, Colonização e Escravidão na Guiana Brasileira - séculos XVIII e XIX. Belém: Editora Universitária/UFPA, 1999. p. 225-318.
} 
Marin, ${ }^{33}$ sobre o movimento abolicionista e as alianças matrimoniais na alta sociedade, e as de José Maia Bezerra Neto, ${ }^{34}$ acerca do abolicionismo e da escravidão urbana, têm contribuído para mudar o quadro acima descrito. Quanto ao Amazonas, Patrícia Maria Melo Sampaio assinalou a importância do trabalho compulsório na constituição da riqueza em Manaus e as articulações entre economia agrícola e extrativa. ${ }^{35}$

Tais estudos evidenciaram, entre outros aspectos, a importância da escravidão negra no Vale Amazônico, deixando entrever a ocorrência de situações tão complexas como aquelas das áreas cafeeiras, que conhecemos mais detalhadamente. Segundo Vicente Salles, desde a abolição da escravidão indígena, pela Metrópole portuguesa, até 1888, a escravaria africana tornou-se, quase exclusivamente, a medida de valor da riqueza na região, pois a terra - muito abundante e inexplorada - praticamente não tinha valor. ${ }^{36}$ Uma mão-de-obra tão cara, dada a longa distância entre o Pará e os principais empórios do tráfico negreiro, estava longe do alcance da maioria dos colonos, razão pela qual era utilizada preferencialmente nos trabalhos da lavoura de cana-de-açúcar e na pecuária, onde podiam ser melhor vigiados do que na extração das chamadas drogas do sertão. ${ }^{37}$

Apesar disso, as fugas eram constantes, intensificando-se em períodos específicos, como durante o processo de emancipação política, ${ }^{38}$ a Cabanagem $^{39}$ e após

33 ACEVEDO MARIN, Rosa Elizabeth. "O Pará e o movimento abolicionista". Acervo, Rio de Janeiro, 3 (1): 21-36, jan./jun. 1988; ACEVEDO MARIN, Rosa Elizabeth. Alianças Matrimoniais na alta sociedade paraense no século XIX. Estudos Econômicos 15 (número especial) 153-167, 1985.

${ }^{34}$ Resultados parciais da pesquisa do autor estão em: BEZERRA NETO, José Maia. Escravidão Negra no Grão-Pará. Séculos XVIII e XIX. Belém: Paka-Tatu, 2001.

${ }^{35}$ SAMPAIO, Patrícia Maria Melo. Os Fios de Ariadne. Tipologia de fortunas e hierarquias sociais em Manaus: 1840-1880. Manaus: Editora da Universidade do Amazonas, 1997.

${ }^{36}$ SALLES, Vicente. Op. cit. p. 8.

${ }^{37}$ Ibidem. p. 60; 123-129. Segundo o autor, o açúcar era uma das mais importantes do Pará, chegando a figurar na pauta de exportações do Pará, no século XVIII. As lavouras ocuparam uma área extensa, praticamente em redor do círculo do golfão marajoara, ocupando inclusive a ilha de Marajó e a calha do Tocantins, sendo disseminadas, muitas vezes, por escravos fugidos, que levavam mudas de cana-deaçúcar para mocambos. Quanto à pecuária, desenvolveu-se principalmente na ilha do Marajó. Arthur Napoleão Figueiredo e Anaíza Vergolino-Henry destacaram, também, a participação da mão-de-obra escrava de origem africana na construção de fortificações militares, edifícios urbanos, estaleiros e hospitais, serviços domésticos e até em bandas de música. Era comum os particulares cederem escravos para o Governo realizar obras públicas. VERGOLINO-HENRY, Anaíza; FIGUEIREDO, Arthur Napoleão. A Presença Africana na Amazônia Colonial: uma notícia histórica. Belém: Arquivo Público do Pará, 1990. p. 39.

${ }^{38}$ Em meio ao processo de emancipação política, Felipe Patroni, através do seu jornal $O$ Paraense, acenava com a possibilidade da "fraternidade entre as raças", estimulando os escravos a acreditarem que a ruptura com Portugal traria também o fim do trabalho compulsório. MUNIZ, Palma. Adhesão do GrãoPará à Independência. Apud SALLES, Vicente. Op. cit. p. 208. Sobre a instalação da imprensa no Pará e suas relações com as representações locais do poder colonial e com o liberalismo "vintista" ver: 
a abolição da escravatura na Guiana Francesa, em $1848 .{ }^{40}$ Com a Cabanagem, houve, segundo Vicente Salles, uma desorganização do sistema escravista no Vale Amazônico, devido à fuga dos escravos e à suspensão das importações dessa mão-de-obra. ${ }^{41}$ Foi então que o Brigadeiro Francisco José de Sousa Soares de Andréa, presidente responsável pela "pacificação" da Província, instituiu uma lei determinando o engajamento em todos os municípios das pessoas que neles vagassem sem profissão definida. $^{42}$

O Governo utilizava os Corpos de Trabalhadores, como eram chamadas as milícias constituídas em função desta lei, para realizar obras públicas, mas também os colocavam à disposição dos proprietários rurais, que podiam requisitá-los à administração provincial para realizar serviços em suas propriedades. Outras medidas complementares vieram em seguida, tais como a punição às pessoas que acoitassem escravos fugidos, a organização de expedições para captura de quilombolas e o incentivo à ação de capitães do mato.

Vicente Salles destacou o caráter desmobilizador destas iniciativas, que teriam enfraquecido o ímpeto rebelde da população marginalizada, evitando, assim, a reedição de insurreições como a Cabanagem. O recrutamento evitava, também, que os libertos e a população pobre em geral buscassem se estabelecer na imensidão de terras disponíveis no Vale Amazônico, distanciando-se das lavouras que circundavam os principais núcleos urbanos da Província. A criação dos Corpos de Trabalhadores tinha, portanto, outra finalidade para o Governo Imperial: garantir aos grupos dominantes locais o

COELHO, Geraldo Mártires. Anarquistas, Demagogos \& Dissidentes. A imprensa liberal no Pará de 1822. Belém: Cejup, 1993.

39 Há muitas divergências entre os historiadores da Cabanagem, inclusive acerca da cronologia do movimento. Quanto ao seu término, alguns estudiosos adotaram o ano de 1840, apoiando-se na declaração que o Presidente da Província João Antônio de Miranda fez nesse sentido. Porém, os rebeldes já teriam sido anistiados pelo Imperador em 1839. CRUZ, Ernesto. História do Pará. Belém: Editora da UFPA, s.d. Vol. I. p. 346. Para uma análise historiográfica mais recente, ver: PINHEIRO, Luís Balkar Sá Peixoto. Visões da Cabanagem. Uma revolta popular e suas representações na historiografia. Manaus: Editora Valer, 2001.

${ }^{40}$ Desde o período colonial, eram constantes as fugas de escravos na fronteira Norte, principalmente entre a Guiana Francesa e o Pará. Após a abolição da escravatura na colônia francesa, os escravos brasileiros tinham um estímulo a mais para fugir. Flávio dos Santos Gomes publicou vários trabalhos sobre as fugas de escravos e a formação de quilombos naquela região, durante o período colonial, entre os quais destacamos: GOMES, Flávio dos Santos. Fronteiras e Mocambos: o protesto negro na Guiana Brasileira. IN: GOMES, Flávio dos Santos (org.). Nas Terras do Cabo Norte. Op. cit. p. 231-326.

${ }^{41}$ De acordo com Vicente Salles, o último carregamento de "negros novos" ocorreu em 1834, ou seja, no ano anterior ao início do conflito. A partir de então, o Pará só receberia escravos através do comércio regional, geralmente originários do Maranhão. SALLES, Vicente. Op. cit. p. 272.

42 Ibidem. p. 272-273. 
suprimento de braços e assim reconquistar sua simpatia, abalada após tantos anos de "motins políticos". 43

Não se sabe ao certo por quanto tempo existiram os Corpos de Trabalhadores. Na década de 1840, segundo Vicente Salles, um presidente de província reclamou dos abusos cometidos, afirmando que estavam se convertendo numa espécie de servidão e surtindo um efeito contrário àquele para o qual haviam sido criados, pois muitas pessoas evadiam da região para não serem recrutadas. ${ }^{44}$ É importante ressaltarmos que, no mesmo período, o Senador Vergueiro e outros fazendeiros paulistas realizavam, com o apoio do Governo Imperial, suas experiências com imigrantes europeus e que, no Pará, a borracha se destacava na pauta de exportações, intensificando, portanto, a demanda por mão-de-obra. ${ }^{45}$

Assim, a historiografia relativa ao meado do século XIX indica que, naquele período, os grupos dominantes de São Paulo e do Pará, apoiados pelo Governo, buscavam soluções específicas para um problema comum: o suprimento de braços. Mas havia diferenças significativas, sendo uma das principais o fato de que a atividade em expansão no Vale Amazônico não se utilizava da mão-de-obra escrava de origem africana, mas principalmente índios e mestiços. Isto não significava, contudo, que as pressões inglesas contra o tráfico negreiro e, principalmente, as leis emancipacionistas promulgadas a partir de 1871 causassem preocupação apenas em São Paulo. O problema se agravava no Pará devido às pressões exercidas pela economia da borracha sobre a agricultura e outros setores, sobretudo considerando-se que os grupos ligados à exploração agro-pecuária tinham interesse em expandir seus negócios.

Segundo Roberto Santos, os deslocamentos sucessivos da população para as zonas produtoras de borracha criaram problemas de continuidade da produção nas demais atividades do setor primário, principalmente as agrícolas. Até 1878, toda ou quase toda a mão-de-obra utilizada na extração e preparo da borracha seria de origem

\footnotetext{
${ }^{43}$ A expressão "motins políticos" foi utilizada, na segunda metade do século XIX, por Domingos Antônio Rayol - o Barão de Guajará - para designar as agitações ocorridas no Pará a partir do processo de emancipação política, ao qual a Província foi forçada a aderir. A Cabanagem seria, assim, um desdobramento daquelas agitações. RAIOL, Domingos Antônio. Motins Políticos: ou história dos principais acontecimentos políticos da Província do Pará desde o ano de 1821 até 1835. Belém: Universidade Federal do Pará, 1970. 3 v.

${ }^{44}$ SALLES, Vicente. Op. cit. p. 274.

45 Para Roberto Santos a "expansão gomífera" teve início em 1840 e se estendeu até 1910. SANTOS, Roberto. História Econômica da Amazônia. 1800-1920. São Paulo: T. A. Queiroz, 1980. p. 13.
} 
indígena. ${ }^{46}$ A partir de então, grandes levas de cearenses começaram a chegar ao Vale Amazônico, mas o recrutamento de índios se estendeu até o século XX, o que significava que a demanda por mão-de-obra continuava intensa. Nas décadas de 1860 e 1870, o estrangulamento da produção de alimentos só não teria sido fatal devido à imigração européia e o deslocamento de parte do contingente nordestino para o setor agrícola.

O sonho de uma colonização agrícola dirigida, numerosa e bem organizada, de acordo com Roberto Santos, jamais se realizou no Pará. Os resultados das tentativas levadas a cabo no século XIX foram medíocres, principalmente em comparação com as depesas do Tesouro Público e empresas particulares. As causas do fracasso, enumeradas pelo autor, ${ }^{47}$ foram: a baixa qualidade do imigrante estrangeiro, em razão da completa falta de seleção; a errônea localização das colônias, sob o ponto de vista econômico; ${ }^{48}$ a inépcia administrativa dos órgãos oficiais encarregados. $\mathrm{O}$ quarto e principal fator seria a falta de apoio do Governo Imperial, uma vez que sua política imigratória tendia a favorecer o Sul do país, onde a economia cafeeira se achava em plena expansão. ${ }^{49}$

De acordo com Barbara Weinstein, porém, o principal problema era a incapacidade da elite paraense para chegar a um consenso no que se referia às possibilidades de desenvolvimento da Amazônia. ${ }^{50}$ Havia, segundo a autora, uma divisão entre a elite política, que reivindicava mais incentivos do Governo Imperial para o incremento da agricultura, e a elite econômica, que almejava uma política econômica favorável à produção e comercialização da borracha. Este último grupo teria criado obstáculos para a adoção de uma política imigrantista, por acreditar que os europeus não se adaptariam ao trabalho de extração do látex.

A análise da Bárbara Weinstein se assemelha àquelas dos autores que consideraram a opção pelo trabalho livre como decorrente de uma mentalidade capitalista, propensa a adotar meios para racionalizar a produção. A autora estabeleceu

\footnotetext{
${ }^{46}$ Ibidem. p. 61-63.

${ }^{47}$ Ibidem. p. 91-92.

${ }^{48}$ Segundo o autor, os colonos foram instalados em regiões onde predominavam o latossolo amarelo, indicado somente para culturas permanentes e, assim mesmo quando observados certos cuidados. A floresta foi derrubada e queimada, deixando o solo ainda mais exposto à erosão. Ibidem. p. 103-105.

${ }^{49}$ As tentativas de imigração estrangeira dirigida elencadas pelo autor foram: portuguesa e chinesa, com o Barão de Mauá em 1854; norte-americana (1866-67), francesa (1875), açoriana (1886) e luso-espanhola (1896-1900). Ibidem. p.117.

${ }^{50}$ WEINSTEIN, Barbara. A Borracha na Amazônia: Expansão e Decadência (1850-1920). Trad. de Lólio Lourenço de Oliveira. São Paulo: Hucitec-Edusp, 1993. p. 135.
} 
comparações entre a cafeicultura e o extrativismo, concluindo que as condições nas quais a borracha era produzida - os coletores conservavam alto grau de controle sobre suas condições de trabalho e sua mobilidade lhes permitia livrar-se de exigências intoleráveis - dificultou ou impossibilitou a exploração racional da mão-de-obra. ${ }^{51}$ Já os setores interessados em promover o desenvolvimento da agricultura local teriam percebido que o trabalho livre do imigrante era mais produtivo do que o trabalho compulsório, mas, devido à sua influência limitada no cenário político, não foram capazes de extrair do Governo Imperial o mesmo volume de recursos colocados à disposição do setor cafeeiro.

Há, contudo, vertentes da historiografia brasileira que rejeitam, na explicação dos fenômenos históricos, o estabelecimento de análises dualistas, como aquelas centradas na oposição entre litoral e sertão, campo e cidade, setores progressistas e arcaicos. $^{52}$ Eles consideram, entre outras coisas, que tais clivagens, além de esquemáticas, minimizaram a importância das pressões exercidas pelos grupos subalternos, como escravos, libertos, trabalhadores livres nacionais e imigrantes europeus, no processo histórico em questão.

Robert Slenes, por exemplo, demonstrou que os cafeicultores paulistas tidos como progressistas continuaram investindo em escravos e obtendo boas margens de lucro até às vésperas da abolição final. ${ }^{53}$ Se os proprietários que investiam em escravos não estavam agindo irracionalmente, do ponto de vista econômico, modelos explicativos fundados na polarização entre setores arcaicos e setores progressistas, ou pré-capitalistas e capitalistas, necessitam ser revistos. Entretanto, as conclusões deste autor não tiveram impacto na historiografia sobre a transição do trabalho escravo para o

\footnotetext{
${ }^{51}$ A autora destacou ainda a escassa circulação de "moeda sonante" nas relações de produção e troca, o que impedia a acumulação de capitais pelos agentes envolvidos e, portanto, a diversificação da produção e seu aperfeiçoamento, visando a maximização de lucros. O resultado disso seria a incapacidade da comunidade mercantil amazônica de controlar o setor de exportação, permanecendo sempre na dependência das flutuações do mercado internacional. Em quase toda a cadeia de produção e comercialização, o que se verificava, segundo a autora, era a "síndrome do débito", ou seja, uma "escravidão por dívidas" em que o seringueiro devia ao seringalista, este à casa aviadora, a casa aviadora ao comerciante estrangeiro. Ibidem. p. 19-51.

${ }^{52}$ A crítica ao dualismo foi elaborada, inicialmente, por Caio Prado Júnior, sendo posteriormente desenvolvida por alguns de seus seguidores. Para um resumo da discussão, ver: LINHARES, Maria Yedda; SILVA, Francisco Carlos Teixeira da. Op. cit. p. 37-70. Para uma análise crítica da bibliografia que estabelece a diferenciação entre Oeste Paulista e Vale do Paraíba, além do texto citado de Jacob Gorender, ver: EISENBERG, Peter. A mentalidade dos fazendeiros no Congresso Agrícola de 1878. Op. cit. p. 167-194.

${ }^{53}$ SLENES, Robert. Grandeza ou Decadência? Op. cit. p. 89-122.
} 
trabalho livre em outras regiões, apesar de terem sido publicadas há praticamente duas décadas.

Em meados da década de 1960, Antônio da Rocha Penteado argumentava que a economia da borracha contribuiu de forma significativa para o incremento da agricultura e até mesmo para a colonização e imigração na Província do Pará, contrariando uma concepção corrente, desde o século XIX, de que o crescimento de uma atividade prejudicava a outra. ${ }^{54}$ Mais recentemente, Luciana Marinho Batista reforçou o ponto de vista de Rocha Penteado, ao verificar que a atividade de coleta dos produtos da floresta não implicava necessariamente num abandono das atividades agrícolas. $^{55}$ Além disso, a elite paraense realizava investimentos econômicos e estabelecia alianças familiares e de amizades, agregando interesses na agricultura, comércio e extrativismo.

As conclusões de Luciana Marinho Bastista, inviabilizando aquelas análises dicotômicas, que separam interesses agrícolas daqueles vinculados aos negócios da borracha, corroboraram as de Patrícia Maria Melo Sampaio, cuja pesquisa concentrouse na região de Manaus. ${ }^{56}$ Alguns anos antes, Rosa Elisabeth Acevedo Marin afirmara que as famílias de latifundiários se uniram, por casamento, com as de funcionários públicos, magistrados e políticos, superando, assim, divergências que remontavam ao período da emancipação política e da Cabanagem. ${ }^{57}$ Há, contudo, uma diferença, pois Rosa Elisabeth Acevedo Marin concluiu que o panorama social do Pará se modificou com a expansão dos negócios da borracha, devido a emergência dos grupos ligados ao comércio e que a "classe alta", constituída nos anos anteriores dentro do aparelho de Estado, não teria contraído muitas alianças com o novo setor. Entretanto, as pesquisas da autora se voltaram principalmente ao período anterior ao da expansão dos negócios

\footnotetext{
${ }^{54}$ PENTEADO, António Rocha. Problemas de Colonização e de Uso da Terra na Região Bragantina do Estado do Pará. Lisboa: Junta de Investigações do Ultramar, 1968. p. 54-55.

55 BATISTA, Luciana Marinho. Muito além dos seringais: elites, fortunas e hierarquias no Grão-Pará, c. 1850 - c. 1870. Dissertação (Mestrado em História). Departamento de História, Universidade Federal do Rio de Janeiro, Rio de Janeiro, 2004. p. 69.

${ }^{56}$ Em estudo sobre a composição da riqueza na sociedade de Manaus, entre 1840 e 1880, Patrícia Maria Melo Sampaio observou que, ao contrário do que afirmava a historiografia relativa à região, havia uma combinação entre atividades agrícolas e extrativas. SAMPAIO, Patrícia Maria Melo. Op. cit.

${ }^{57}$ ACEVEDO MARIN, Rosa Elisabeth. Alianças matrimoniais na alta sociedade paraense no século XIX. Op. cit.
} 
da borracha, diferentemente das de Patrícia Maria Melo Sampaio e Luciana Marinho Batista. $^{58}$

Em outro estudo, Elisabeth Acevedo Marin contrariou a concepção de que o abolicionismo se desenvolveu apenas nas áreas mais urbanizadas da atual região Sudeste e algumas capitais do Nordeste. Segundo a autora, não havia diferenças significativas entre o abolicionismo do Pará e o das demais regiões. Favorecido pela rápida circulação de idéias e doutrinas entre a Província e os grandes centros intelectuais nacionais e estrangeiros, o movimento abolicionista de Belém possuía caráter muito semelhante ao do Rio de Janeiro, ou seja, era organizado pelas elites locais e visava principalmente a garantir que o processo de emancipação se desse de forma lenta, gradual e sem riscos para os grandes proprietários. ${ }^{59}$

Estes estudos indicam, portanto, a necessidade de serem revistas algumas teses correntes na historiografia brasileira sobre as relações entre as atuais regiões Centro-Sul e Norte, durante o século XIX. Entre elas destacamos a de que o extrativismo se constituiu em obstáculo ao desenvolvimento da agricultura no Vale Amazônico, sendo, inclusive, um dos fatores que levaram ao fracasso das tentativas colonizadoras e imigrantistas. Necessita, também, ser revista, pois decorre da anterior, a tese segundo a qual havia um choque de interesses entre uma elite política - constituída por representantes dos setores agrários - e uma elite mercantil - envolvida nos negócios de coleta e exportação de produtos da floresta - o qual teria inviabilizado a obtenção de recursos junto ao Governo Imperial para financiar a imigração e colonização do Pará.

Torna-se inevitável, portanto, uma discussão sobre a participação do Governo Imperial na solução dos problemas regionais, sobretudo aqueles relacionados com a questão do suprimento de mão-de-obra. Afinal, como vimos, parte da historiografia brasileira concebe que, a partir da emancipação política do país, as elites agrárias da região Centro-Sul estabeleceram sua hegemonia sobre todo o território, através de um Estado centralizado, que ignorava os interesses dos grupos marginalizados, enquanto outros autores advogam a existência de arranjos políticos nos quais os interesses tanto das elites centrais como das elites provinciais eram contemplados.

\footnotetext{
${ }^{58}$ Ibidem. p. 162-167,

59 ACEVEDO MARIN, Rosa Elizabeth. "O Pará e o movimento abolicionista". Acervo, Rio de Janeiro, 3 (1): 21-36, jan./jun. 1988. p. 26.
} 
Desde o final do século XIX, pelo menos, a literatura relativa à Amazônia empregou de maneira recorrente a palavra "deserto" para assinalar a escassa presença grupos humanos ditos "civilizados" na região, ${ }^{60}$ desconsiderando a existência e a história das populações indígenas e caboclas ali estabelecidas, obscurecendo, senão legitimando, o genocídio e exploração predatória da natureza. ${ }^{61} \mathrm{Da}$ mesma forma, mas por caminhos diferentes, a literatura relativa a São Paulo vinculou a imigração européia à questão do suprimento de braços para as lavouras de café, criando com isso a idéia de que apenas fazendeiros e escravos habitavam a região. A questão do povoamento e, conseqüentemente, do extermínio dos grupos indígenas não foi assim considerada pela historiografia que se dedicou ao estudo das últimas décadas da escravidão em São Paulo. Mesmo a importação de trabalhadores asiáticos, uma das alternativas de suprimento de mão-de-obra que era considerada no período, foi pouco discutida pela historiografia.

Há pontos em comum entre a experiência paulista e a paraense, entre eles o fato de que setores expressivos das elites locais esperavam que viesse de fora a solução para seus problemas de mão-de-obra e de povoamento. Ou seja, eles pareciam querer evitar a possibilidade de que se constituísse no país um mercado de trabalho livre composto majoritariamente por ex-escravos e depender do recrutamento dos braços livres existentes no país. Embora a adoção de medidas para coagir os braços disponíveis ao trabalho produtivo foi freqüente em todo o país, principalmente nas últimas décadas da escravidão, a principal expectativa era de que o Governo Imperial promovesse a importação de trabalhadores e assim se constituísse um mercado de trabalho com mãode-obra barata, disciplinada e dependente.

\footnotetext{
${ }^{60}$ No final do século XIX, José Coelho da Gama e Abreu, o Barão de Marajó, rememorou o decreto que criou a Companhia de Navegação e Comércio do Amazonas (1852) e o decreto que abriu o Amazonas ao comércio internacional, afirmando que o Brasil e as repúblicas limítrofes, com suas "extensões desertas, com seus raros e poucos habitados centros de população" necessitavam de medidas como aquelas para incentivar a imigração. Quase cem anos depois, o governo militar utilizou o slogan "Amazônia: terra sem homens para homens sem terra" a fim de incentivar a "colonização" da região e, assim, atenuar os conflitos agrários em outras áreas do país. Ver: BARÃO DE MARAJÓ. As regiões amazônicas. Estudos chorographicos dos Estados do Gram Pará e Amazonas. 2a . ed., Belém: Secult, 1992, p. 369. Sobre a colonização da Amazônia no período militar, ver: IANNI, Octavio. Colonização e Contra-Reforma Agrária na Amazônia. Petrópolis: Vozes, 1979.

${ }^{61}$ BECKER, Bertha K. Amazônia. $3^{\text {a }}$. ed., São Paulo: Ática, 1994. p. 9-10. Para uma análise específica sobre os conflitos étnicos e a territorialidade na Amazônia ver: ACEVEDO, Rosa; CASTRO, Edna. Negros do Trombetas. Guardiães de matas e rios. $2^{\mathrm{a}}$ ed. Belém: CEJUP, 1998.
} 
Não obstante, a historiografia brasileira privilegiou o estudo sobre o projeto de dominação engendrado na região Centro-Sul, cujas elites, por sua trajetória e formação, teriam se diferenciado das demais elites regionais e a elas imposto seus interesses. Esta concepção pode ser encontrada na noção de "interiorização da metrópole", ${ }^{62}$ formulada por Maria Odila Silva Dias, na de "idéias fora do lugar", 63 de Roberto Schwartz, na de "formalismo brasileiro", ${ }^{64}$ utilizada por autores como Guerreiro Ramos, Wanderley Guilherme dos Santos e José Murilo de Carvalho; na metáfora da "moeda colonial", ${ }^{65}$ concebida por Ilmar Rohloff de Matos, e em várias outras interpretações sobre a construção do Estado e da nação no Brasil.

De um modo geral, a despeito de algumas divergências, estes autores conceberam que as elites da região Centro-Sul adotaram idéias e instituições alheias, muitas vezes conflitantes com a realidade nacional, mas apropriadas para garantir a preservação de seus interesses. Nesse sentido, ao mesmo tempo em que mantinham as articulações com o mundo de origem ou de referência, as elites dominantes exerciam sua hegemonia através de um Estado centralizado.

Dessas concepções decorrem argumentações segundo as quais as elites regionais, supostamente submetidas no processo de emancipação política e de construção do Estado Nacional, seriam dotadas de uma "miopia localista", ou seja, estavam voltadas apenas para seus interesses locais, sendo incapazes de engendrar projetos políticos alternativos ou de se articular com a Coroa e com as elites dominantes de forma a negociar seus interesses. Em trabalhos recentes, ${ }^{66}$ Miriam Dolhnikoff

${ }^{62}$ DIAS, Maria Odila Silva. A interiorização da metrópole. Op. cit.

63 SCHWARTZ, Roberto. As idéias fora do lugar. In: SCWARTZ, Roberto. Ao Vencedor as Batatas. Forma literária e processo social nos inícios do romance brasileiro. $2^{\mathrm{a}}$. ed. São Paulo: Duas Cidades, 1981. p.13-28.

${ }^{64}$ De acordo com essa concepção, a elite imperial teria uma clara noção do objetivo a atingir, qual seja a instauração de uma ordem liberal burguesa. Para José Murilo de Carvalho, que lançou dúvidas sobre as dimensões dessa clarividência, o Conselho de Estado seria um locus de poder do grupo dirigente. Localizados no ápice da burocracia imperial, os Conselheiros tinham uma visão privilegiada dos horizontes distantes e dos perigos que pudessem ameaçar suas defesas, embora não conseguissem perceber e refletir sobre os que se passava a seus pés, nos porões do sistema político. CARVALHO, José Murilo de. Teatro de Sombras: A política imperial. São Paulo: Vértice; Rio de Janeiro: IUPERJ, 1988. p. 130-132; RAMOS, Guerreiro. O tema da transplantação e as enteléquias na interpretação sociológica do Brasil. Apud ibidem; SANTOS, Wanderley Guilherme dos. Ordem Burguesa e Liberalismo Político. São Paulo: Duas Cidades, 1978.

${ }^{65}$ MATTOS, Ilmar Rohloff de. O Tempo Saquarema. A formação do Estado Imperial. São Paulo: Hucitec, 1990.

${ }^{66}$ DOHLNIKOFF, Miriam. As elites regionais e a construção do Estado Nacional. In: JANCSÓ, István (org.). Brasil: Formação do Estado e da Nação. São Paulo: HUCITEC/FAPESP; Ijuí: Ed. Unijuí, 2003. 
argumentou que a manutenção da unidade do território luso-americano, sob a hegemonia de um único Estado, e a organização política do Brasil Imperial não foram conseguidas graças a um processo pelo qual uma elite dirigente regional se transformou em elite nacional, impondo sobre todo o território seus interesses, mas resultaram de uma intensa negociação entre as elites provinciais e o poder central. Este arranjo institucional teria sido necessário porque o Estado carecia de um aparelho burocrático e administrativo capaz de impor sua hegemonia sobre todo o território, dadas as dificuldades de comunicação e de transportes e a escassez de funcionários, entre outros fatores.

$\mathrm{Na}$ apresentação de uma obra coletiva, ${ }^{67}$ da qual faz parte um dos trabalhos citados de Miriam Dohlnikoff, István Jancsó afirmou não ser mais consistente a idéia segundo a qual o Estado brasileiro foi demiurgo da nação, uma vez que, dada a maneira como seu deu a ocupação do território e a organização econômica e social da Colônia, uma série de identidades regionais se consolidaram nas primeiras décadas do século XIX, provocando conflitos e cooperações instáveis. Assim, ao invés de promover a coesão interna, com base em valores universais, que é o fundamento da idéia de nacionalidade, o Estado brasileiro acabou por se tornar instrumento de poucos na luta pela manutenção de seus privilégios e aspirações.

Em seu estudo sobre os conflitos antilusitanos ocorridos na Corte, durante o Primeiro Reinado, ${ }^{68}$ Gladys Sabina Ribeiro assinalou que, em meio ao processo de construção da Nação e da busca de símbolos mais genéricos, que representassem a extensão de todo o território brasileiro, prevaleceu uma forte repressão contra os estrangeiros, mas também contra o povo, em especial os escravos e libertos. Tratava-se, então, de evitar que estes grupos, que se julgavam muitas vezes co-responsáveis e partícipes do processo de emancipação política, se aliassem aos imigrantes e pobres em geral, ameaçando os interesses dos grupos dominantes.

Apesar de suas especificidades, estas análises nos ajudaram a refletir sobre o tema do presente trabalho, qual seja o processo de reorganização do mercado de

p. 431-468; DOHLNIKOFF, Miriam. O Pacto Imperial. Origens do federalismo no Brasil. São Paulo: Globo, 2005.

${ }^{67}$ JANCSÓ, István. Este livro. In: JANCSÓ, István (org.). Brasil: Formação do Estado e da Nação. Op. cit. p. 15-28.

${ }^{68}$ RIBEIRO, Gladys Sabina. A Liberdade em Construção. Identidade nacional e conflitos antilusitanos no Primeiro Reinado. Rio de Janeiro: Relume Dumará, 2002. 
trabalho nas últimas décadas do regime monárquico. $\mathrm{O}$ argumento que desenvolveremos aqui, ao longo dos quatro capítulos que se seguem, é que as representações sobre o trabalhador imigrante não diziam respeito apenas a seus referentes imediatos, mas principalmente aos trabalhadores nacionais, livres ou escravos, e às dificuldades em recrutá-los e explorá-los. Através de um jogo de imagens, invertendo qualidades e defeitos que atribuíam à força de trabalho existente no país, jornalistas e administradores de província não estavam aludindo a um trabalhador real, mas construindo representações que evidenciavam, também, as relações que estabeleciam com o Governo Imperial.

Em termos historiográficos, corroboramos as interpretações que concebem a existência de negociações entre as elites dirigentes do Governo Imperial e as elites regionais, e não uma subordinação destas por aquelas. Através da comparação entre semelhanças e especificidades de duas Províncias - São Paulo e Pará - argumentamos que os grupos envolvidos na produção agro-exportadora procuravam conseguir a adesão de setores mais amplos ao seu projeto político. Ao investirem na idéia da properidade futura da nação, condicionando-a ao desenvolvimento da agricultura de exportação, tentavam evitar que propostas alternativas de desenvolvimento fossem gestadas, prejudicando seus interesses.

Não nos parecem convincentes, portanto, as análises que estabelecem clivagens regionais ou que associam o crescimento do movimento abolicionista e a formulação de políticas públicas em prol da imigração européia a um suposto aumento dos crimes cometidos pelos escravos. Afinal, não foram apresentados dados quantitativos que demonstrem ter ocorrido um recrudescimento dessa criminalidade nas décadas que antecederam a Abolição. ${ }^{69}$

\footnotetext{
${ }^{69}$ Ciro Flamarion S. Cardoso assinalou o problema metodológico de se estabelecer um corte qualitativo no tempo - no caso, o recrudescimento da rebeldia negra nos anos finais da escravidão, ou seja, o aumento do número de crimes e revoltas coletivas - sem que se proceda a uma cuidadosa análise quantitativa e sistemática. Mesmo não recorrendo à quantificação, chegamos a uma conclusão semelhante à do autor, analisando o discurso das elites paulistas do final do século XIX. Encontramos indícios de que mesmo nos momentos mais tensos os fazendeiros e políticos não tomavam decisões com base num suposto medo da rebeldia dos escravos e de que estes utilizaram estratégias mais sofisticadas e eficazes para conseguir fazer valer seus interesses. Ver: CARDOSO, Ciro Flamarion. A abolição como problema histórico e historiográfico. In: CARDOSO, Ciro Flamarion S. (org.). Escravidão e abolição no Brasil. Novas perspectivas. Rio de Janeiro: Jorge Zahar, 1988. p. 88. QUEIROZ, Jonas Marçal de. Da Senzala à República. Tensões sociais e disputas partidárias em São Paulo (1869-1889). Dissertação (Mestrado em História), Departamento de História, UNICAMP, Campinas, 1995.
} 
O estabelecimento de relações de causa e efeito, tais como aquelas que apontamos entre abolicionismo e imigrantismo ou entre ambos e a luta dos escravos, bem como de clivagens regionais ou de qualquer outro tipo não apresentaram, no nosso entendimento, resultados satisfatórios. O processo de reorganização do mercado de trabalho livre deve ser interpretado, portanto, nas suas relações com questões mais gerais, tais como as tentativas de modernização do Estado, em curso na segunda metade do século XIX, os embates político-partidários, a discussão acerca da formação da identidade nacional e o nativismo, a disponibilidade de recursos para a instalação de trabalhadores recém-chegados, as dúvidas quanto às possibilidades de assimilação cultural dos estrangeiros etc.

Estas questões remetem para a necessidade de empreendermos pesquisas tendentes a aprofundar as análises acerca das representações do mundo social que emergiram em meio aos debates sobre a elaboração de projetos voltados para a introdução de trabalhadores livres, de origem européia, no país. ${ }^{70}$ Nosso objetivo, ao pesquisar comparativamente as Províncias de São Paulo e Pará, foi o de testar a hipótese de que tanto as propostas de imigração européia quando as de utilização do trabalhador cearense, no caso do Pará, estavam relacionadas com a construção da imagem do "trabalhador ideal", que não guardavam relações apenas com seus referentes imediatos, mas também com aquelas produzidas acerca dos trabalhadores existentes naquelas regiões.

Nesse sentido, as imagens produzidas sobre o imigrante estrangeiro e o migrante nordestino, aqueles que estavam por vir, seriam, até certo ponto, imagens invertidas do escravo, do índio e do trabalhador livre nacional. ${ }^{71}$ Ao estudá-las,

\footnotetext{
${ }^{70} \mathrm{O}$ conceito de representação é aqui empregado tal como foi definido por Roger Chartier. De acordo com o autor, as representações do mundo social, embora aspirem à universalidade de um diagnóstico fundado na razão, são sempre determinadas pelos interesses de grupo que as forjam, o que significa que não são discursos neutros: produzem estratégias e práticas que tendem a impor uma autoridade à custa de outros, por ela menosprezados, a legitimar um projeto reformador ou a justificar suas escolhas e condutas. CHARTIER, Roger. A História Cultural: entre práticas e representações. Rio de Janeiro: Bertrand Brasil, 1990. p. 17.

${ }^{71}$ Peter Eisenberg assinalou uma importante lacuna na historiografia relativa ao século XIX: o trabalhador livre nacional. Atribuindo-a à concepção de que escravidão e trabalho livre seriam sistemas historicamente incompatíveis, o autor propôs a realização de estudos sobre regiões em que a escravidão não exerceu um papel preponderante, como nas áreas cuja economia era dominada pelas lavouras de exportação podem, também, contribuir para tirar do anonimato o trabalhador livre nacional. Outras questões viriam à tona, como a do povoamento e do extermínio dos povos indígenas, pouco discutidas pela historiografia relativa às ultimas décadas da escravidão nas áreas cafeeiras. EISENBERG, Peter. O Homem Esquecido: o trabalhador livre nacional no século XIX. Sugestões para uma pesquisa. In:
} 
podemos conhecer um pouco mais sobre os conflitos envolvendo os trabalhadores, seus empregadores e uma ampla gama de agentes históricos formada por legisladores, burocratas, redatores de jornais etc. Podemos aprofundar, também, a discussão sobre as relações entre o Governo Imperial e as elites regionais.

Para tanto, selecionamos, como principais fontes de estudo, artigos publicados em jornais e os relatórios e falas dos presidentes de província. Em termos metodológicos, seguimos as reflexões de Mikhail Bakhtin sobre o caráter dialógico do discurso. Segundo este autor, entre o discurso e o objeto, entre ele e quem o enuncia, interpõe-se discursos de outrem, que a este objeto também se referem. ${ }^{72}$ Assim, todo discurso encontra o objeto para o qual está voltado envolvido num emaranhado de idéias gerais, pontos de vista, apreciações, julgamentos e entonações, ou seja, enredado pelo que já foi dito sobre ele. $\mathrm{O}$ discurso penetra neste meio dialogicamente perturbado e tenso, entrelaçando-se com estes outros discursos em interações complexas. Os "fios dialógicos" que ele inevitavelmente acaba por tocar são tecidos pela consciência ideológica construída em torno do objeto, em determinado momento social e histórico, o que acaba por transformá-lo em participante ativo do diálogo social. Além disso, todo discurso está também orientado para o discurso-resposta que ainda não foi dito, mas que ele solicita surgir.

Entre os jornais publicados na Província de São Paulo, entre 1868 e 1889, analisamos artigos e notícias do Gazeta de Campinas, A Província de São Paulo, Correio Paulistano, Tribuna Liberal e Opinião Liberal; dos publicados na Província do Pará, no mesmo período, pesquisamos o A Província do Pará; Diário de Belém, Diário de Notícias e $O$ Liberal do Pará. Os jornais publicados nas últimas décadas do século XIX eram, aparentemente, muito semelhantes. Apresentavam, em geral, quatro páginas, sendo as duas últimas dedicadas aos anúncios e editais. Na primeira página eram publicados o editorial, o folhetim e artigos em geral. Alguns jornais dispunham os anúncios ou publicações oficiais na primeira página, o que é indicativo de onde provinha a principal fonte de financiamento da empresa.

Homens Esquecidos. Escravos e Trabalhadores Livres no Brasil. Séculos XVIII e XIX. Campinas (SP): Editora da UNICAMP, 1989. p. 223-244.

${ }_{72}$ BAKHTIN, Mikhail. Questões de Literatura e de Estética. A teoria do romance. Trad. De Aurora Fornoni Bernadini e outros. 4. ed., São Paulo: Hucitec, 1998. p. 85-106. 
A maioria dos periódicos relacionados acima estava vinculada a algum partido ou facção política, mas nem sempre os jornais se designavam "órgão oficial" dessa ou daquela agremiação. O comum era cada partido ter um "órgão oficial” nas capitais de província e cidades importantes, como era o caso de Campinas. Além dos Anúncios, as seções mais freqüentes eram a editorial, a noticiário e a "Seção Particular" ou "A Pedidos". Suas características eram bem distintas. A seção Editorial, geralmente publicada nas primeiras colunas do jornal, exprimia o ponto de vista dos redatores e proprietários do jornal. Contudo, os redatores não a intitulavam assim, ou seja, não recebia este rótulo, sendo identificada pelo fato de ser iniciada com a indicação do local e data em que o exemplar do jornal era publicado. Em seu espaço eram tratados assuntos considerados relevantes, geralmente de natureza política, como a substituição de presidentes de província, comentários sobre a atuação dos legisladores provinciais e gerais e os grandes temas do período: o processo de emancipação da escravatura, a imigração e colonização, as dificuldades orçamentárias das administrações provincial e imperial etc. No caso dos jornais de oposição, principalmente os de orientação republicana, o editorial exercia uma função pedagógica, enfatizando e reiterando pontos de vista contrários à ordem vigente, indicando omissões e equívocos. Já a seção "noticiário" não tinha um caráter opinativo tão evidente. Como o próprio rótulo indica, ela veiculava informes sobre acontecimentos comezinhos da localidade: a partida ou chegada à cidade de uma família importante, nascimentos, casamentos ou mortes de pessoas com alguma projeção social, crimes etc. Muitas deles eram transcritas de outros periódicos ou fatos presenciados pelo próprio redator, ou ainda a ele transmitidos por pessoas de sua confiança. A seção "a pedidos", que em alguns jornais recebia o título de “seção particular", era o local por excelência para a participação dos leitores, que podiam fazer publicar artigos ou comunicados de seu interesse, mediante pagamento. As redações geralmente estabeleciam uma espécie de código de ética para publicações neste espaço com o intuito de evitar artigos contendo calúnias e difamações. Contudo, era principalmente nesse espaço que se davam as polêmicas, intrigas e debates, dos quais muitas vezes os próprios redatores ou pessoas ligadas ao jornal participavam, geralmente utilizando pseudônimos.

Apesar de aparentemente difusos, os artigos e notícias publicados nos jornais eram coerentes. Isto pode ser explicado, em parte, pelo fato de a sua redação estar aos 
cuidados de uma ou de poucas pessoas. Não é difícil percebermos, portanto, que os conteúdos das seções, para além de sua especificidade, se complementavam ou se reforçavam, o que não significa que inexistiam contradições. Ao transcreverem artigos ou notícias de outros periódicos, os redatores introduziam modificações, suprimiam trechos ou adicionavam comentários, o que nos permite concluir que não se tratavam de publicações apenas para preencher espaço ou que um artigo transcrito de outro periódico tivesse importância menor do que um editorial, por exemplo.

Ao lado das Assembléias Provinciais e do Parlamento, a imprensa do período tornou-se um espaço privilegiado para o exercício de discussões e tomadas de posição frente às questões que surgiam. Passando por um rápido processo de modernização, que lhes dava condições de acompanhar e participar com mais agilidade dos debates que ocorriam em várias instâncias da vida nacional, os jornais pareciam conquistar um prestígio cada vez maior entre os leitores, que esperavam deles alguma contribuição para solucionar os problemas que os afligiam. Isto se devia, também, ao fato de os proprietários e redatores dos mesmos geralmente serem pessoas com poder de decisão, como vereadores, ministros e parlamentares.

A importância da imprensa se fazia sentir principalmente nas regiões mais afastadas da capital do Império e com escassa representação no Parlamento, como era o caso da Província do Pará, que até 1884 elegia apenas três deputados gerais e um senador. ${ }^{73}$ Apesar de não contar com os mesmos recursos que os principais periódicos do país desfrutavam, sobretudo de um serviço telegráfico, que possibilitava maior rapidez no recebimento e divulgação de notícias, os jornais paraenses publicados durante as últimas décadas da Monarquia estavam em sintonia com os principais debates que ocorriam em outras províncias. ${ }^{74}$

\footnotetext{
${ }^{73}$ A partir de 1885, o número de representantes do Pará aumentou para seis, na Câmara dos Deputados, e três, no Senado, como conseqüência da reforma eleitoral de 1881. São Paulo, que elegia nove deputados gerais e quatro senadores, continuou elegendo estes mesmos números de representantes. Ver: BARÃO DE JAVARI (org.). Organizações e Programas Ministeriais. Regime parlamentar do Império. $3^{\text {a }}$ ed. Brasília: Ministério da Educação e Cultura, 1979. p. 383 e 415; LEITE, Beatriz Westin de Cerqueira. $O$ Senado nos Anos Finais do Império. 1870-1889. Brasília: Senado Federal/Editora da UNB, 1978. p. 48.

${ }^{74}$ O Diario do Gram-Pará, fundado em março de 1853, foi o primeiro jornal cotidiano do Pará; em 1868 surgiu o Diário de Belém. Estes dois jornais estavam ligados ao Partido Conservador, sendo que apenas o primeiro se designava "órgão oficial". Em 1869 foi fundado o periódico $O$ Liberal do Pará, que a exemplo do A Provincia do Pará, fundado em 1876, tinha ligações com o Partido Liberal. O principal órgão republicano, A República, surgiu em 1886. Vários outros jornais não admitiam vínculos com partidos, como foi o caso do Diário de Noticias, fundado em 1880. BARATA, Manoel. Jornais, revistas e outras publicações periódicas (1822 a 1908). In: Formação Histórica do Pará. Belém: Universidade Federal do Pará, 1973. p. 243-254.
} 
Entre suas características, destaca-se o fato de que alguns se apresentavam como prolongamentos do mercado e outros dos partidos políticos. Quanto aos primeiros, expressavam essa característica trazendo, em seus espaços mais privilegiados, anúncios do comércio local, preços de mercadorias e o movimento portuário. Juntamente com estes anúncios, mas num local de menor destaque, vinham os editoriais, os artigos de colaboração, as transcrições de matérias publicadas em outros periódicos e as notícias locais, nacionais e internacionais. Já os periódicos vinculados aos partidos políticos, tanto os que assumiam a condição de órgão oficial dessa ou daquela agremiação como os que se colocavam apenas como porta-vozes de grupos ou facções, reservavam suas colunas mais importantes para a discussão dos grandes temas locais, regionais e nacionais e — quando se tratava de um jornal da situação — para as publicações oficiais. $^{75}$

Como observou Roger Chartier, até os séculos XVII e XVIII, os jornais não tinham uma estrutura muito diferente daquela dos livros. Depois disso, adquirem um grande formato e uma distribuição ampla, passam a ser vendidos nas ruas, são carregados, dobrados, rasgados, lidos por muitos. ${ }^{76}$ No Brasil, esta mudança ocorre a partir da década de 1850, com a introdução das tipografias a vapor. Paulatinamente, os jornais ampliam seu formato, adicionando seções novas, mudam a diagramação e os caracteres, tornam-se diários e passam a ser vendidos nas ruas, trens e barcos. Um pouco mais adiante e a difusão do telégrafo e do telefone provocam outra revolução, tornando mais ágil a veiculação das notícias. Muitas empresas passam a afixar, nos prédios onde estão instaladas, telegramas contendo notícias que, no dia seguinte, estariam estampadas nas páginas dos jornais. ${ }^{77}$

\footnotetext{
${ }^{75}$ Em São Paulo, o jornal Correio Paulistano, que começou a ser publicado em 1854, passou por diversas fases, sendo porta-voz de liberais, conservadores e republicanos em fases específicas. Durante alguns anos, seu proprietário, Roberto de Azevedo Marques, negociava a parte editorial do jornal, administrando apenas a seção de anúncios. Os jornais Gazeta de Campinas e A Provincia de São Paulo, fundados em 1869 e 1875, respectivamente, estavam vinculados aos republicanos, enquanto o Tribuna Liberal, fundado em 1879, e Opinião Liberal, fundado em 1881, aos liberais.

${ }^{76}$ CHARTIER, Roger. A Aventura do Livro do Leitor ao Navegador. Conversações com Jean Lebrun. Trad. Reginaldo Carmello Corrêa de Moraes. São Paulo: Unesp, 1999. p. 82.

77 Segundo Nelson Werneck Sodré, o Diário de São Paulo, fundado em 1865, por Pedro Taques de Almeida Alvim, Delfino Pinheiro de Ulhôa Cintra Júnior e Henrique Schroeder, instalou em 1874 a primeira máquina de impressão de jornal em grande formato na Província de São Paulo. Em 1878, estas máquinas passariam para o Correio Paulistano. Em Campinas, o periódico Gazeta de Campinas tinha como redatores e colaboradores vários políticos republicanos como Campos Salles, Rangel Pestana, Américo Brasiliense e Francisco Quirino dos Santos. Este mesmo grupo participaria da fundação do $A$
} 
A velocidade com que notícias e opiniões circulam, aumentam a percepção que os leitores têm entre o seu mundo e os outros mundos. ${ }^{78}$ É exatamente esta duplicidade do conteúdo jornalístico, ou seja, a alternância entre sua abrangência mais extensa e seu localismo particularista, ${ }^{79}$ que torna a imprensa uma fonte privilegiada para a compreensão das questões suscitadas pelo encaminhamento político da emancipação da escravatura. Afinal, a maneira como a elite agrária pretendia ver solucionada a "magna questão", isto é a criação de uma força de trabalho numerosa, disciplinada e dependente, por meio da aprovação de um conjunto de políticas públicas que ia desde a promoção da imigração subvencionada pelo Estado até a elaboração de códigos municipais destinados a arregimentar a mão-de-obra disponível para o trabalho no campo, exigia o conhecimento de interlocutores, a construção de identidades e o estabelecimento de alianças com setores cujos interesses aproximavam-se dos seus.

É sabido que desde meados do século XIX, pelo menos, setores expressivos da elite agrária brasileira já demonstravam certa disposição em eliminar, ou pelo menos diminuir, sua dependência em relação ao trabalho escravo. Os fatores que concorriam para esta atitude e as tentativas que foram feitas naquele sentido variaram muito de região para região. A partir do momento em que o governo passou a interferir mais efetivamente nas relações entre senhores e escravos, antecipando as expectativas quanto ao desfecho final da questão escravista, percebe-se que tal orientação passou a ganhar cada vez mais adeptos.

Foi então que muitos depositaram suas esperanças na instrução pública, concebida como uma das formas mais eficazes de se adequar a mentalidade dos trabalhadores às necessidades decorrentes das transformações que estavam em curso. ${ }^{80}$ Isto seria feito através de escolas técnicas de agricultura, criadas para esse fim, mas cogitava-se também a possibilidade de serem adotadas medidas coercitivas para forçar

Provincia de São Paulo. SODRÉ, Nelson Werneck. A História da Imprensa no Brasil. Rio de Janeiro: Civilização Brasileira, 1966. p. 258-259.

${ }^{78}$ Citando Michel de Certeau, Roger Chartier afirmou que "o leitor é um caçador que percorre terras alheias”. CHARTIER, Roger. A Aventura do Livro do Leitor ao Navegador. Op. cit. p. 77.

${ }_{79}$ Para uma análise sobre o papel desempenhado pela imprensa nas sociedades modernas, centrada na questão da constituição do Estado-nação, ver: ANDERSON, Benedict. Nação e Consciência Nacional. Trad. de Lólio Lourenço de Oliveira. São Paulo: Ática, 1989.

${ }^{80}$ SANTOS, Ana Maria dos; MENDONÇA, Sonia Regina de. "Representações sobre o trabalho livre na crise do escravismo fluminense (1870-1903)". Revista Brasileira de História, São Paulo, v. 6, n. 11, set. 1985/fev. 1986. 
os ociosos e vadios ao aprendizado ou diretamente ao trabalho produtivo. ${ }^{81}$ Como parte desta política, aventava-se ainda a preparação dos ex-escravos, sobretudo dos ingênuos e libertos em decorrência da Lei do Ventre Livre, para competir no mercado de trabalho em fase de reorganização.

Além dos jornais, outra fonte pesquisada foram os relatórios e falas dos presidentes de província. A nomeação de um presidente, conforme observou Richard Graham, ${ }^{82}$ era de extrema importância, pois se tratava da primeira autoridade nas províncias. Como tal, ele representava o próprio imperador, sendo recebido cerimoniosamente quando chegava à capital provincial: a bandeira imperial era hasteada e uma guarda de honra dava-lhe as boas-vindas, em meio a fogos de artifício e músicas. A legislação exigia dele que executasse as diretrizes estipuladas pelo gabinete que o indicara para ser nomeado e assegurasse o cumprimento das leis, sobretudo da Constituição. Essas contingências o faziam se envolver em numerosos assuntos, sendo que o principal deles era gerar dividendos eleitorais para o gabinete ministerial.

O Ato Adicional de 1834 determinou que os presidentes das comparecessem às sessões anuais de abertura dos trabalhos das assembléias legislativas provinciais, para dar uma notícia circunstanciada do estado dos negócios públicos e indicar-lhes as providências que julgasse necessárias para o seu melhoramento. Já o Aviso-Circular de 11 de março de 1848 determinou que todo presidente de província, ao deixar o cargo, apresentasse um relatório detalhado da sua administração aos deputados provinciais, o qual era posteriormente publicado.

Os relatórios e falas dos presidentes das províncias são fontes pouco exploradas pela historiografia brasileira. Talvez porque ainda pese sobre elas as críticas que eram feitas pelos adversários políticos dos administradores, como a de que eles permaneciam pouco tempo no cargo e eram oriundos de outras regiões. Estas críticas, comuns em todo o Império, foram reproduzidas em muitas análises, sem que os estudiosos tivessem o cuidado de compreendê-las no seu contexto mais amplo. Num período em que a burocracia imperial tentava introduzir no país uma série de reformas modernizadoras,

\footnotetext{
${ }^{81}$ Várias propostas foram apresentadas nesse sentido durante o Congresso Agrícola de 1878, organizado pelo Presidente do Conselho de Ministros, João Lins Vieira Cansansão de Sinimbú. Ver: Congresso Agrícola. Introdução e notas de José Murilo de Carvalho. Rio de Janeiro: Fundação Casa de Rui Barbosa, 1988, Ed. fac-similar.

82 GRAHAM, Richard. Clientelismo e Política no Brasil do Século XIX. Trad. Celina Brandt. Rio de Janeiro: Editora UFRJ, 1997. p. 86.
} 
que contrariavam interesses estabelecidos, mas não consolidados, era natural que os presidentes de província fossem o alvo preferido dos grupos que controlavam, ou aspiravam a controlar, o poder político no âmbito regional.

Nesse sentido, os relatórios e falas não podem ser tomados como uma descrição fiel dos problemas e das realizações governamentais, mas como textos que evidenciam, entre outras coisas, embates entre grupos e facções políticas. Ambas as fontes eram redigidas para serem avaliadas pelos deputados das assembléias legislativas provinciais. Só isto basta para que consideremos toda a carga de pressão que pesava sobre os presidentes no momento prestar contas da sua administração e quando solicitavam, através das Falas, o apoio dos deputados para seus projetos. É verdade que o governo sempre vencia as eleições durante o Império. As câmaras formadas por políticos de um único partido não foram exceções. Porém, o fato de as assembléias provinciais não serem passíveis de dissolução, como ocorria com a Câmara dos Deputados, fez com que em algumas oportunidades os presidentes de província governassem com assembléias constituídas majoritariamente por políticos da oposição.

Mas a circulação dos relatórios e falas não ficava restrita ao âmbito das Assembléias Provinciais. Eram publicados nos jornais e editados na forma de livro. $\mathrm{O}$ novo presidente, sobretudo quando vinha de outras regiões, lia o relato dos seus antecessores. O mesmo faziam os viajantes estrangeiros que percorriam o país, os redatores de jornais, editores de almanaques e todos aqueles que buscavam dados sobre a situação das províncias em termos de segurança e força pública, finanças e obras públicas, instrução, núcleos coloniais, emancipação, escolas, hospitais etc. Os relatórios e falas dos presidentes de Província eram, portanto, muito mais do que um relato técnico restrito aos gabinetes.

O recorte cronológico da pesquisa foi escolhido por se tratar de um período consagrado pela história política no Brasil como de declínio do regime monárquico. $\mathrm{O}$ ano de 1868 marcou a substituição dos liberais pelos conservadores na organização do Ministério, abrindo uma etapa de grandes mudanças. Entre estas, podemos destacar a aprovação das leis emancipacionistas de 1871 e 1885, culminando com a abolição em 1888; a crise entre o Estado e a Igreja, que resultou na prisão dos Bispos do Pará e de Olinda, em 1874; o lançamento do Manifesto Republicano de 1870; as crises entre políticos e militares, que irromperam alguns anos depois do término da Guerra do 
Paraguai, sendo a principal delas o Golpe que resultou na proclamação da República; e a introdução de uma série de reformas, de caráter modernizador, no Estado brasileiro, a saber: reforma eleitoral, reforma do judiciário, mudança no recrutamento militar etc. Além disso, havia pressões no sentido da laicização do Estado com a instituição do casamento e do registro civis, da liberdade religiosa, da secularização dos cemitérios.

Estes e outros aspectos justificam um estudo como o que apresentamos aqui, uma vez que se trata de discutir como as elites regionais e o Governo Imperial equacionaram a questão da reorganização do mercado de trabalho tendo em vista a proximidade da abolição final. Por seu efeito catalizador, a questão da constituição de uma força de trabalho numerosa, disciplinada e depedente envolveu quase todas as questões enumeradas no parágrafo acima.

Por fim, uma advertência. Evitamos, sempre que possível, as transcrições de longos trechos das fontes, mas em muitos casos reproduzimos, entre aspas, palavras, expressões e frases tal como aparecem nas fontes, na tentativa de transmitir ao leitor a intensidade das imagens veiculadas pelas fontes que compulsamos. Também aparecem entre aspas as seções dos jornais e os itens dos relatórios dos presidentes de província. A ortografia foi atualizada, com exceção dos títulos de obras, nomes de pessoas e de lugares. 


\section{Capítulo I}

\section{Males do Presente e Esperança do Futuro}

\subsection{Amazônia: inferno e paraíso}

Em 1868, o Presidente da Província do Pará, Joaquim Raymundo de Lamare, ${ }^{1}$ afirmou que a receita daquele ano havia sido superior à de 1867, o que ele atribuía à prosperidade do comércio, mais precisamente às exportações de produtos naturais. ${ }^{2}$ Uma evidência disso seria o êxito da Companhia de Navegação do Amazonas, ${ }^{3}$ beneficiada pela elevação do preço da goma elástica no mercado internacional e, conseqüentemente, pelo aumento da produção de borracha. ${ }^{4}$ Entretanto, recomendava algumas medidas para melhorar o estado financeiro do Pará, como a substituição do gás pelo azeite na iluminação pública, uma vez que a Província era muito rica em oleaginosas, ${ }^{5}$ e a realização de reformas na repartição de obras públicas. ${ }^{6}$

De acordo com o Presidente, o fato de a população do Pará conseguir obter facilmente seu sustento prejudicava a agricultura e a "indústria". Isto porque boa parte da vida econômica dos habitantes da Província prescindia da produção de uma das duas atividades, dado que o regime alimentar era baseado em uma economia extrativa de subsistência. ${ }^{7}$ Não se tratava da primeira vez - nem seria a última - que o extrativismo era considerado um obstáculo ao progresso regional. Os administradores reconheciam a

\footnotetext{
${ }^{1}$ Pará. Relatorio com que o excellentissimo senhor Vice-Almirante e Conselheiro de Guerra Joaquim Raymundo de Lamare passou a administração da Provincia do Gram-Pará ao excellentissimo senhor Visconde de Arary, $1^{o}$. Vice-Presidente, em 6 de agosto de 1868. Belém: Typ. do Diario do Gram-Pará, 1868.

${ }^{2}$ Ibidem. p. $25-29$

${ }^{3}$ Ibidem. p. 34. O Presidente se referia à Companhia de Comércio e Navegação do Amazonas, fundada por Irineu Evangelista de Souza, o Barão de Mauá, em 1852, que, inicialmente, tinha o privilégio exclusivo da navegação do rio Amazonas e seus afluentes por trinta anos. Em 1854, o Barão de Mauá desistiu do privilégio e a companhia foi autorizada a estabelecer quatro linhas regulares de paquetes a vapor, recebendo subvenção do Governo Imperial e a concessão de propriedades nas margens do rio, nas quais deveria fundar colônias agrícolas e industriais. De acordo com Roberto Santos, a abertura do Amazonas à navegação internacional, proclamada por ninguém menos do que o Vice-Almirante e Conselheiro de Guerra Joaquim Raymundo de Lamare, em solenidade realizada no dia 7 de setembro e 1867, deu início ao declínio da Companhia. SANTOS, Roberto. História Econômica da Amazônia: 18001920. São Paulo: T. A. Queiroz, 1980. p. 55-59.

${ }^{4}$ Ibidem. p. 45.

5 Ibidem. p. 38.

${ }^{6}$ Ibidem. p. 36.

${ }^{7}$ Ibidem. p. 25-26.
} 
contribuição que a coleta e comercialização de produtos naturais da floresta traziam, principalmente aos cofres públicos, mas geralmente acreditavam que somente os empreendimentos agrícolas e "industriais" trariam um progresso duradouro e não restrito apenas à capital. ${ }^{8}$

Em relação à situação econômica, o quadro traçado por Joaquim Raymundo de Lamare foi reforçado, em linhas gerais, por vários presidentes que governaram o Pará entre o final da década de 1860 e o início da seguinte, como o cônego Siqueira Mendes, José Bento da Cunha Figueiredo e Abel Graça. Apenas o Visconde de Arary acrescentou, aos problemas já apontados, o desequilíbrio que a Guerra do Paraguai provocava nas finanças provinciais. Até mesmo o comércio, segundo ele, começava a ser afetado pelo conflito na região do Prata. ${ }^{9}$ Já em relação à agricultura, o cônego Siqueira Mendes foi o único a demonstrar otimismo, afirmando que seu progresso era equiparável ao do comércio. ${ }^{10}$

Não é fácil encontrar regularidades nas avaliações que os presidentes faziam da economia local e do estado da Administração Provincial. O fato de ocuparem o cargo por um período muito breve e de serem, em geral, provenientes de outras regiões têm sido apontado por alguns estudiosos como um fator que explicaria as dificuldades na continuidade administrativa e até mesmo o conhecimento, pelo Administrador, dos problemas e potencialidades regionais. ${ }^{11}$ Para se ter uma idéia, segundo Ernesto Cruz, entre setembro de 1868 e novembro de 1889, a Província do Pará teve 45 administradores, o que significa que, em média, cada governante permaneceu menos de seis meses no cargo. ${ }^{12}$

\footnotetext{
${ }^{8}$ Como observou Barbara Weinstein, já no período colonial a Metrópole portuguesa estimulava esta crença, mas os colonizadores percebiam que as condições ambientais da Amazônia estavam longe de ser ideais para o desenvolvimento de uma economia agrícola. WEINSTEIN, Barbara. A Borracha na Amazônia: Expansão e Decadência (1850-1920). Trad. Lólio Lourenço de Oliveira. São Paulo: Hucitec, 1993. p. 25.

${ }^{9}$ Pará. Relatorio com que o excellentissimo senhor Visconde de Arary entregou a administração da provincia do Gram-Pará ao excellentissimo senhor $1^{\circ}$. Vice-Presidente conego Manoel José de Siqueira Mendes, em 29 de setembro de 1868. Belém: Typ. do Diario do Gram-Pará, 1868. p. 10.

${ }^{10}$ Pará. Relatorio com que o excellentissimo senhor primeiro Vice-Presidente conego Manoel José de Siqueira Mendes entregou a administração da provincia do Gram-Pará ao excellentissimo senhor conselheiro José Bento da Cunha Figueiredo, em 18 de outubro de 1868. Belém: Typ. do Diario do Gram-Pará, 1868. p. 8-9.

${ }^{11}$ WEINSTEIN, Barbara. Op. cit. p. 55.

${ }^{12}$ Nesse total estão incluídos presidentes e vice-presidentes. Estes últimos geralmente assumiam o cargo no intervalo entre a exoneração de um presidente e a nomeação de outro. Considerando apenas os presidentes, teríamos que cada um permaneceu no cargo pouco mais de um ano, em média. Mas os dados apresentados por Ernesto Cruz contêm falhas. O próprio Joaquim de Lamare aparece na sua relação
} 
Em primeiro lugar, devemos considerar que os administradores da Província não tinham à sua disposição indicadores eficientes das atividades desenvolvidas na região. Muitos deles, aliás, apontavam para a necessidade de serem produzidas estatísticas confiáveis. Além disso, a dimensão das províncias, as dificuldades de locomoção, a escassez de quadros burocráticos e o despreparo dos que estavam a serviço das administrações eram entraves consideráveis. Quanto à afirmação de que muitos presidentes eram oriundos de outras regiões e que, portanto, desconheciam a realidade regional, é preciso lembrar que se trata de uma crítica estabelecida já naquele período e muito difundida pelo país, a qual foi incorporada, sem reservas, por alguns historiadores.

Segundo Richard Graham, ${ }^{13}$ os administradores das províncias serviam ao belprazer do Presidente do Conselho de Ministros que, em seu constante rearranjo da burocracia nacional, mudava-os de uma província para outra com grande freqüência. Além disso, muitos deles ocupavam simultaneamente uma cadeira no Congresso e, no início de cada período legislativo, partiam para o Rio de Janeiro, deixando em seu lugar um dos seis vice-presidentes governando. Estes, em geral, eram políticos influentes em seus partidos, residiam na própria província e davam continuidade à política do presidente. Às vezes, também, um presidente de outra região era escolhido para governar uma província porque as facções locais estavam muito divididas, sendo difícil a escolha do representante de uma delas sem que isso gerasse fortes reações do grupo rival.

O problema está em desconsiderar aquilo que era a essência do cargo, ou seja, que os presidentes se viam como delegados dos gabinetes ministeriais pelos quais eram nomeados, e não como representantes dos interesses regionais. Sua tarefa era, portanto, realizar, no âmbito das províncias, as diretrizes estabelecidas pelo programa de governo do Presidente do Conselho de Ministros. É claro que sofriam pressões dos grupos regionais que faziam oposição ao Governo, inclusive de facções dentro do seu próprio partido. Estes grupos, com representação nas assembléias legislativas provinciais, nas câmaras municipais e no Parlamento, acusavam os presidentes de desconhecerem a

apenas em 1867, sendo que ocupou a presidência também em 1868. CRUZ, Ernesto. História do Pará. Belém: Governo do Estado do Pará, s.d., 2º vol., p. 686-688.

${ }^{13}$ GRAHAM, Richard. Clientelismo e Política no Brasil do Século XIX. Trad. Celina Brandt. Rio de Janeiro: Editora UFRJ, 1997. p. 86-87. 
realidade das províncias que administravam e o governo de removê-los antes que isso ocorresse.

As críticas só não eram mais veementes porque o Governo vencia praticamente todas as eleições. ${ }^{14}$ Mas elas existiam e, paradoxalmente, contribuíam, algumas vezes, para a queda de presidentes de província. Por outro lado, como observou Francisco Iglésias, o posto era muito mais político do que administrativo, representando para muitos um estágio de carreira ou uma oportunidade para prestar pequenos serviços ao gabinete ministerial. Assim, muitos presidentes deixavam a presidência de uma província para governar outra, para assumir postos mais importantes ou porque se elegiam para o Senado ou Câmara dos Deputados. ${ }^{15}$ Todavia, o mais importante, como observou o autor em relação a Minas Gerais, é que apesar das constantes remoções de presidentes havia uma política econômica que se mantinha constante. Isto ocorria exatamente pelo fato de que eles executavam, no âmbito provincial, diretrizes estabelecidas pelo governo geral. ${ }^{16}$

Portanto, os relatórios e falas dos presidentes de província devem ser tomados como fontes produzidas pelos administradores para sugerir, no caso das falas aos deputados, a aprovação de medidas afinadas com a política do Governo e prestar contas, no caso dos relatórios, das realizações da administração. Não há nessas fontes um relato fiel do estado da agricultura, do comércio, da indústria e das finanças públicas da província, mas pontos de vistas, impressões e expectativas que traduziam a ideologia de políticos, facções, partidos ou grupos políticos suprapartidários, que constituíam a elite política imperial. Como observou Miriam Dolhnikoff, em seu estudo sobre as elites regionais e a construção do Estado Nacional, havia articulações entre a elite política imperial e as elites regionais, mesmo porque muitas das ações das administrações

\footnotetext{
${ }^{14}$ Há situações em que a maioria de uma assembléia provincial ou câmara municipal não pertencia ao partido do governo. Isto porque, diferentemente do que acontecia com a câmara de deputados, as assembléias provinciais e câmaras municipais não eram passíveis de dissolução. Uma situação assim ocorreu em 1878, quando os liberais reassumiram o governo, nomeando para a presidência das províncias políticos da sua agremiação, que tiveram de conviver com deputados provinciais e vereadores eleitas durante o período de domínio dos conservadores.

15 IGLÉSIAS, Francisco. Política Econômica do Governo Provincial Mineiro (1835-1889). Rio de Janeiro: Ministério da Educação e Cultura, 1958. p. 204.

${ }^{16}$ Segundo Francisco Iglésias, a instabilidade política não alterava a continuidade da política econômica porque, como os governos se propunham poucas tarefas - devido a falta de recursos, por preocupações em outros sentidos ou pela ideologia do tempo - não havia distinção muito nítida entre a política econômica do Partido Conservador e do Partido Liberal. Ao longo deste capítulo e dos seguintes procuraremos mostrar que os partidos políticos tinham diretrizes distintas e, por vezes, conflitantes tanto em relação à política econômica como às propostas de suprimento de braços e outros assuntos.
} 
provinciais dependiam das decisões dos deputados provinciais. ${ }^{17} \mathrm{O}$ debate sobre a reorganização do mercado de trabalho nas últimas décadas da Monarquia, em especial aquele a respeito da imigração estrangeira, o demonstra com clareza, pois a criação de núcleos coloniais, a assinatura de contratos com agentes ou empresas de imigração, por exemplo, só ocorriam quando autorizados pela Assembléia Provincial.

Assim, nem mesmo a prosperidade do comércio evitava que os administradores apontassem problemas nesse setor e sugerissem medidas para melhorá-lo. O Conselheiro José Bento da Cunha Figueiredo, que qualificou de "espantoso" o desenvolvimento comercial da Província e sugeriu a construção de um novo cais em Belém, ${ }^{18}$ assinalou que entre o baixo e o alto Amazonas o comércio estava em "estado primitivo" e as povoações eram pequenas devido, em grande parte, às dificuldades de comunicação. ${ }^{19} \mathrm{Na}$ tentativa de minimizar este problema, o conselheiro teria promovido a abertura de estradas para facilitar o escoamento da produção agrícola da região de Bragança, principal área produtora de alimentos da Província, em direção à capital. ${ }^{20}$

A melhoria das finanças públicas parece ter permitido ao cônego Siqueira Mendes, ${ }^{21}$ que ocupou novamente a presidência da Província em 1870, dar continuidade às obras iniciadas pelo seu antecessor, como prédios para a acomodação de colonos norte-americanos $^{22}$ e o início da construção de uma estrada de ferro ligando Belém a Bragança. $^{23}$ Além disso, sugeriu aos deputados que, ao longo dessa estrada, fossem criadas colônias agrícolas para instalar outros estrangeiros. Entretanto, ainda em 1870, o Vice-Presidente Abel Graça propôs uma contenção dos gastos públicos, argumentando

${ }^{17}$ DOLHNIKOFF, Miriam. Elites Regionais e a Construção do Estado Nacional. In: JANCSÓ, István (org.). Brasil: Formação do Estado e da Nação. São Paulo: Hucitec, 2003. p. 431-468.

${ }^{18}$ Pará. Relatorio com que o excelentíssimo senhor Presidente da Provincia Conselheiro José Bento da Cunha Figueiredo entregou a administração da Provincia do Gram Pará ao excelentíssimo senhor $2^{o}$. Vice-Presidente coronel Miguel Antonio Pinto Guimarães. Em 16 de maio de 1869. Belém: Typografia do Diario do Gram-Pará, 1869, Annexos, Documento nº 10, p. 11.

${ }^{19}$ Ibidem. documento ${ }^{\circ} .29$, p. 29.

${ }^{20}$ Ibidem. p. 10.

${ }^{21}$ Pará. Relatorio com que o excelentissimo senhor conego Manuel José de Siqueira Mendes primeiro Vice-Presidente da provincia do Pará passou a administração da mesma ao excelentissimo senhor Presidente João Alfredo Corrêa de Oliveira. Belém: Typographia do Diario do Gram-Pará, 1870, p. 6.

${ }^{22} \mathrm{O}$ estabelecimento de imigrantes norte-americanos no Pará teve início em 1866, quando o major Lansford Warren Hastings e a Administração Provincial firmaram um contrato nesse sentido. CRUZ, Ernesto. Colonização do Pará. Belém: Instituto Nacional de Pesquisas da Amazônia, 1958. p. 31-32.

${ }^{23} \mathrm{O}$ cônego Siqueira Mendes não esclareceu os gastos com a construção da Estrada de Ferro Belém Bragança, cuja primeiro trilho só seria assentado em 1883. Pela lei $n^{\circ}$. 658, de 31 de outubro de 1871, o Governo Provincial procurou atrair interessados na sua construção, mas durante toda a década de 1870 e início da seguinte travou-se um intenso debate na Assembléia Provincial e através da imprensa acerca do traçado da ferrovia e outras questões. CRUZ, Ernesto. História do Pará. Op. cit. vol. 2. p. 585. 
que o estado financeiro da Província não era "lisonjeiro". ${ }^{24}$ Mesmo assinalando que o comércio da Província crescera $400 \%$ em apenas 18 anos, ${ }^{25}$ ele declarou que sua administração se vira obrigada a contrair empréstimos junto ao banco Mauá \& Cia, no valor de 200 contos de réis. ${ }^{26}$

Esta situação parece ter se agravado em 1872. Segundo o Barão da Villa da Barra, o estado das finanças provinciais era tão precário que não fora possível realizar melhoramentos nos serviços da administração nem pagar as despesas indispensáveis. ${ }^{27}$ Em razão disso, autorizou a emissão de apólices, mas recomendou a realização de um recenseamento na Província para evitar gastos desnecessários e orientar os investimentos. ${ }^{28} \mathrm{O}$ único ponto positivo assinalado pelo Administrador foi a elevação da renda em $97.372 \$ 175$ - apesar de o preço da borracha estar em queda no mercado internacional - o que teria ocorrido em função do aumento da quantidade de goma elástica exportada em $1871 .^{29}$ Quanto ao comércio, a avaliação do Barão da Villa da Barra acompanhava a dos seus contemporâneos: aumentava progressivamente e a praça comercial de Belém era uma das mais importantes do Império, não obstante seu elevado custo de vida. ${ }^{30}$

A maioria dos administradores que ocuparam a presidência da Província entre o final da década de 1860 e o início da seguinte chegou à conclusão de que o estado financeiro do Pará era precário. Apesar de preconizarem o incremento da agricultura,

\footnotetext{
${ }^{24}$ Pará. Relatorio apresentado a Assembléa Legislativa Provincial na primeira sessão da $17^{a}$. legislativa, pelo quarto Vice-Presidente Dr. Abel Graça. Belém: Typ. do Diario do Gram-Pará, 1870. p. 12.

${ }^{25}$ No mesmo relatório de Abel Graça, o inspetor da alfândega, Augusto Cézar Sampaio, analisou as oscilações no comércio e produção da província, observando que a elevação das tarifas de importação, conjugada com um aumento do valor exportado, havia gerado um saldo positivo de $25 \%$ de 1868 a 1869 , e de $35 \%$ de 1869 a 1870 . Segundo ele, esse crescimento se devia, principalmente, ao bom preço da borracha, e não propriamente ao aumento da produção. Assim, teria ocorrido um desenvolvimento excepcional da província, muito superior às demais, pois o qüinquiênio de 1865 a 1870 conhecera um crescimento de $527,57 \%$ em relação ao de 1845 a 1850 . O mesmo, porém, não ocorria com a agricultura, uma vez que, segundo o inspetor, a extração da borracha absorvia grande parte da mão-de-obra disponível no Pará, no Amazonas e Maranhão. A produção da borracha atingira em 1868-1869 um crescimento de renda para o Império de $24,13 \%$, sendo a maior parte pertencente ao território da província do Amazonas. Por outro lado, era notável, segundo o inspetor, a diminuição das exportações de alguns produtos como o arroz e o açúcar. Ibidem. p. 23-33.

${ }^{26}$ Segundo Abel da Graça, com a entrada no mercado da capital de seu principal gênero de exportação - a goma elástica - entre setembro e dezembro, possivelmente não haveria necessidade de contrair todo o empréstimo. Ibidem. p. 52-55.

${ }^{27}$ Pará. Relatorio apresentado pelo exm. sr. Barão da Villa da Barra em 5 de novembro de 1872 por occasião de passar a administração da provincia ao $2^{\circ}$ Vice-Presidente o exm. sr. Barão de Santarém. Belém: Typ. do Diario do Gram-Pará, 1872, p. 36.

${ }^{28}$ Ibidem. p. 33-34.

${ }^{29}$ Ibidem. p. 36-38.

${ }^{30}$ Ibidem. p. 51-54.
} 
quase todos depositavam esperanças na atividade extrativa como forma de resolver os problemas imediatos da Província. Nesse sentido, estabeleciam uma dissociação entre as duas atividades, sobretudo no que se referia à demanda por braços. Como não acreditavam que os imigrantes europeus ou norte-americanos se adaptassem ao trabalho de coleta da goma elástica, preconizavam a colonização como forma de resolver o problema da escassez de alimentos na capital da Província. Em todo caso, propunham a instalação de colônias apenas nas áreas onde o extrativismo era pouco expressivo e de fácil acesso ao mercado de Belém, devido ao receio de que abandonassem o trabalho agrícola por uma atividade mais lucrativa.

A partir do início da década de 1870, uma crise nos negócios da borracha deixou os administradores ainda mais pessimistas em relação às possibilidades de desenvolvimento regional. Os relatórios e falas produzidos entre 1873 e 1880 são praticamente unânimes em assinalar o estado precário das finanças da Província. O Barão de Santarém, por exemplo, lamentou o decréscimo nas arrecadações entre $1871 \mathrm{e}$ $1873,{ }^{31}$ atribuindo-o à diminuição dos preços da borracha no mercado internacional e da população nas regiões de Cametá e Breves. Os seringueiros estariam abandonando aquelas áreas devido a incidência de epidemias e para buscar seringais mais produtivos. Diante desse quadro, o Administrador declarou ter sido forçado a emitir apólices e contrair empréstimos para dar continuidade às obras iniciadas pelos antecessores. ${ }^{32}$

Alguns meses depois, Domingos José da Cunha Junior afirmou que o principal esforço de sua administração fora o de tentar melhorar a lamentável situação financeira do Pará, controlando gastos e fiscalizando severamente a arrecadação das rendas provinciais. ${ }^{33}$ Entre julho e dezembro de 1873, segundo ele, ocorrera um decréscimo das mesmas em relação ao mesmo período do ano anterior, o que atribuía à crise no comércio e às epidemias. Entretanto, notava que a Província retomava aos poucos o crescimento econômico interrompido em $1872 .^{34}$

\footnotetext{
${ }^{31}$ Pará. Relatorio com que o excellentissimo senhor Barão de Santarém $2^{\circ}$. Vice-Presidente da Provincia passou a administração da mesma ao excellentissimo senhor doutor Domingos José da Cunha Junior, em 18 de abril de 1873. Belém: Typ. do Diario do Gram-Pará, 1873, p. 22-23.

${ }^{32}$ Ibidem. p. 24.

${ }^{33}$ Ibidem. p. 42.

${ }^{34}$ Pará. Relatorio com que o excellentissimo senhor doutor domingos José da Cunha Junior passou a administração da Provincia do Pará ao $3^{\circ}$. Vice-Presidente o excellentissimo senhor doutor Guilherme Francisco Cruz. Em 31 de dezembro de 1873. Belém: Typographia do "Diário do Gram-Pará",1873, p.4748.
} 
Por vezes, num intervalo de poucos meses, as declarações dos administradores sobre o estado financeiro da Província contrastavam radicalmente. Em 1874, por exemplo, Guilherme Francisco Cruz assinalou que o déficit nas contas públicas podia ser reduzido a um montante liquidável, mediante a conclusão de algumas obras e o aumento da fiscalização. Acreditando numa breve recuperação das finanças da Província, recomendou aos deputados provinciais e aos presidentes que o sucedessem o investimento em vias de comunicação, tanto de navegação como de estradas de ferro, para melhorar a agricultura e a indústria. ${ }^{35}$ Naquele mesmo ano, Pedro Vicente de Azevedo declarou ter ficado decepcionado ao saber que a Província devia 2 mil contos de réis a juros de $8 \%$ ao ano, quantia que teria sido aplicada na construção de obras que considerava luxuosas e improdutivas, como monumentos, ou que atendiam aos interesses de uma minoria. ${ }^{36}$ Segundo o Administrador, devido às crises comerciais, o estado financeiro da Província permitia despesas apenas com o imprescindível. ${ }^{37}$

Ao deixar a administração, cerca de um ano mais tarde, Pedro Vicente de Azevedo relembrou que encontrara os cofres da Província "exaustos", que a dívida pública era enorme e que os contratos firmados pelos seus antecessores eram desfavoráveis à administração. ${ }^{38}$ Quanto à agricultura, estaria praticamente "anulada", dadas a carência de braços em virtude do "monopólio" destes pelo "fabrico" da borracha. ${ }^{39}$ Por causa disso, a Província era obrigada a importar produtos básicos como o açúcar e o arroz. ${ }^{40}$ Apenas a capital da Província, segundo ele, com seu ativo comércio e prédios suntuosos, transmitia uma imagem de animação e progresso. ${ }^{41}$

\footnotetext{
${ }^{35} \mathrm{O}$ fato de o Administrador fazer recomendações aos seus sucessores evidenciava um hábito comum dos presidentes de província: a leitura dos relatórios e falas dos seus antecessores. Vários deles comentaram ou transcreveram trechos de relatórios anteriores, o que reforça nossa idéia de que os relatórios não eram textos com caráter meramente técnico, mas que eram lidos, avaliados, debatidos e apropriados. Ver: Pará. Relatorio com que o excellentissimo senhor doutor Guilherme Francisco Cruz, $3^{\circ}$. Vice-Presidente passou a administração da provincia do Pará ao excellentissimo senhor doutor Pedro Vicente de Azevedo em 17 de janeiro de 1874. Belém: Typ. do Diario do Gram-Pará, 1874. p. 18-19.

${ }^{36}$ Pará. Relatorio apresentado à Assembléa Legislativa Provincial na primeira sessão da $19^{a}$. legislatura pelo Presidente da Provincia do Pará o excellentissimo senhor doutor Pedro Vicente de Azevedo em 15 de fevereiro de 1874. Belém: Typ. do Diario do Gram-Pará, 1874, p. 4.

37 Ibidem. p. 75.

${ }^{38}$ Pará. Relatorio Apresentado ao exm. senr. Dr. Francisco Maria Corrêa de Sá e Benevides pelo exm. senr. Dr. Pedro Vicente de Azevedo por occasião de passar-lhe a Administração da Provincia do Pará, no dia 17 de janeiro de 1875. Belém: Typ. de F. C. Rhossard, 1875. p. 3.

${ }^{39}$ Ibidem. p. 60.

${ }^{40}$ A única exceção seria o município de Bragança. Ibidem. p. 75.

${ }^{41}$ Ibidem. p. 74.
} 
Contrariando a maioria dos presidentes que administraram o Pará naquele período, Pedro Vicente de Azevedo acusou a "intolerância política" de ser a causa dos principais problemas da Província. Somente o comércio, feito em grande parte por estrangeiros, poderia atenuar os problemas causados pelos desmandos e irregularidades, apesar da crise que atingia os negócios da borracha. ${ }^{42} \mathrm{O}$ Presidente não deu detalhes sobre os problemas políticos aos quais se referia. Entretanto, não é difícil supor ao que ele se reportava. O período em que administrou o Pará foi particularmente tenso, devido ao desgaste do Governo em decorrência dos desdobramentos da crise conhecida como Questão Religiosa - a qual resultou na prisão do Bispo do Pará, D. Macedo Costa, e do Bispo de Olinda, D. Vital - e das tentativas de reforma do Estado. ${ }^{43}$

As dificuldades financeiras pareciam tão graves, que o sucessor de Pedro Vicente de Azevedo, Francisco Maria Corrêa de Sá e Benevides, propôs aos deputados provinciais uma diminuição drástica dos gastos públicos. ${ }^{44}$ Até mesmo a construção da estrada de ferro que ligaria Belém a Bragança, de vital importância para o abastecimento agrícola da capital da Província, teve de ser adiada. ${ }^{45}$ No ano seguinte, ao deixar a administração, ele afirmou que, além das dificuldades financeiras, a falta de "habilitações" dos funcionários da administração e o fato de terem de lidar com vários assuntos agravavam a crise da Província. ${ }^{46}$ Em tom de justificativa, afirmou que fora rigoroso na correção de abusos e que não se afastara do programa do Gabinetes Ministerial que lhe havia delegado a tarefa de administrar a Província.

Estas considerações do Presidente indicam que a crise política à qual se referira Pedro Vicente de Azevedo não fora superada. Mas o que nos interessa aqui é ressaltar a atitude de Francisco Maria Corrêa de Sá e Benevides, ou seja, sua demonstração de lealdade ao Gabinete Ministerial. A concepção dialógica do discurso, tal como foi

\footnotetext{
${ }^{42}$ Ibidem. p. 3.

${ }^{43}$ Conforme observou Richard Graham, o Gabinete Rio Branco (1871-1875) realizou praticamente todo o programa apresentado pelo Partido Liberal, através do Clube da Reforma, em 1868: alterou funções da polícia e da magistratura, modificou o recrutamento militar, interveio nas relações entre senhores e escravos, através da Lei do Ventre Livre, promoveu uma reforma eleitoral etc. Para tanto, rompeu com correligionários conservadores, gerando reações que talvez Pedro Vicente de Azevedo estivesse qualificando de "intolerância política". GRAHAM, Richard. Op. cit. p. 226-227.

${ }^{44}$ Pará. Relatorio com que o excellentissimo senhor Doutor Francisco Maria Corrêa de Sá e Benevides Presidente da Provincia abriu a $2^{a}$. sessão da $19^{a}$. legislatura da Assembléa Legislativa Provincial no dia 15 de fevereiro de 1875. Belém: Typ. do Diario do Gram-Pará, 1875, p. 3-4.

${ }^{45}$ Ibidem. p. 40.

${ }^{46}$ Pará. Relatorio com que o exm. sr. Presidente da Provincia do Pará, dr. Francisco Maria Corrêa de Sá e Benevides, entregou a administração da mesma ao exm. sr. dr. João Capistrano Bandeira de Mello Filho em 18 de julho de 1876. Pará, Typ. do Diario do Gram-Pará, 1876. p. 25.
} 
teorizada por Mikhail Bakhtin, ${ }^{47}$ nos ajuda a compreender as referências tanto aos problemas administrativos e financeiros quanto ao programa ministerial. Considerando que os relatórios e falas dos presidentes de província eram produzidos para serem apresentados aos deputados provinciais, é possível que o Presidente estivesse antecipando críticas, que poderiam, inclusive, comprometer seu futuro político. Daí sua preocupação em justificar as dificuldades de sua administração, transferindo responsabilidades para os funcionários. É muito provável que, assim como seu antecessor, ele tenha encontrado dificuldades políticas durante a sua administração.

A partir de 1877, os presidentes passaram a registrar indícios de melhoria nas finanças públicas. A “inversão partidária”,48 ocorrida logo no início do ano seguinte, com o fim de quase dez anos de predomínio do Partido Conservador e a ascensão do Partido Liberal, que organizaria os gabinetes ministeriais até 1885 , pode ter contribuído para a superação, pelo menos momentânea, da crise política. Por outro lado, uma conjuntura internacional favorável também pode ter contribuído para gerar otimismo entre os administradores. Segundo José da Gama Malcher, aquele teria sido o ano mais próspero do período, devido à estabilização dos preços dos gêneros de exportação e à

47 BAKHTIN, Mikhail. Questões de Literatura e de Estética. A teoria do romance. Trad. De Aurora Fornoni Bernadini e outros. 4. ed., São Paulo: Hucitec, 1998. p. 85-106. Conforme esclarece Diana Luz Pessoa de Barros, Bakhtin considera que o texto é tecido polifonicamente por fios dialógicos de vozes, que polemizam entre si, se completam ou respondem umas às outras. Assim, os textos estabelecem um diálogo com vários outros textos da mesma cultura, tornando-se um ponto de intersecção de muitos diálogos. BARROS, Diana Luz Pessoa de. Dialogismo, Polifonia e Enunciação. In: BARROS, Diana Luz Pessoa de; FIORIN, José Luiz (org.). Dialogismo, Polifonia, Intertextualidade. São Paulo: Edusp, 2003. p. 4.

${ }^{48}$ Empregamos o termo "inversão partidária” no sentido dado por Sérgio Buarque de Holanda, ou seja, para designar a situação em que o Imperador, fazendo uso das atribuições do Poder Moderador, destituía do cargo de Presidente do Conselho de Ministros um político de um partido e convocava um político de outro partido para formar um novo gabinete ministerial. Entre 1868 e 1889, ocorreram quatro "inversões partidárias": em 1868, quando os liberais foram substituídos pelos conservadores; em 1878, quando ocorreu o inverso; em 1885, quando novamente os liberais foram substituídos pelos conservadores, e, finalmente, em 1889, quando os liberais voltaram a organizar o gabinete. As "inversões partidárias" provocavam a substituição em massa de funcionários públicos e políticos que ocupavam cargos de confiança, situação sintetizada na expressão "derrubada", empregada pelo mesmo autor. Nas províncias, os primeiros a serem substituídos eram o presidente e o chefe de polícia. Antes mesmo que um presidente do Conselho de Ministros fosse destituído, era comum os chefes políticos locais se reunirem para articular a indicação de pessoas que gostariam de ver ocupando os cargos assim que a "inversão partidária" ocorresse. Quando a troca de presidentes do Conselho de Ministros se dava entre políticos de um mesmo partido, o ímpeto da "derrubada" era menor. HOLANDA, Sérgio Buarque de. Do Império à República. In: HOLANDA, Sérgio Buarque de (dir.). História Geral da Civilização Brasileira. $3^{\mathrm{a}}$. ed. São Paulo: Difel, 1983. Tomo II, vol. 5. 
baixa do câmbio. ${ }^{49}$ Para José Joaquim do Carmo, embora o desenvolvimento da Província estivesse aquém das potencialidades e riquezas que possuía, ${ }^{50}$ suas finanças não eram tão desanimadoras, uma vez que a receita estava sendo aplicada com mais prudência. ${ }^{51}$ Além disso, o desenvolvimento do trabalho e da produção, sobretudo com a chegada de trabalhadores cearenses, estava contribuindo para a recuperação das finanças. ${ }^{52}$

José Coelho da Gama e Abreu, que também destacou o equilíbrio entre as arrecadações e as despesas como um ponto positivo daquele momento, ${ }^{53}$ fez vaticínios sombrios sobre o futuro do Pará, referindo-se à sua excessiva dependência em relação a um único produto de exportação. ${ }^{54}$ A borracha seria a principal responsável pelo "aspecto doentio" da população, razão pela qual os investimentos deveriam ser canalizados para a agricultura, sobretudo na construção de estradas de ferro e na instalação de núcleos coloniais nas suas margens. Entretanto, a Administração Provincial não teria recursos para tanto. ${ }^{55}$

Quase um ano mais tarde, José Coelho da Gama e Abreu se mostrava ainda mais otimista em relação às finanças provinciais, afirmando ter ocorrido uma elevação na receita entre os anos de 1878 e $1879 .{ }^{56}$ Isto devido, segundo ele, ao aumento da safra e do preço da borracha, principalmente, do cacau e da castanha. ${ }^{57}$ A recuperação das finanças teria permitido ao Administrador realizar várias obras na colônia Benevides,

\footnotetext{
${ }^{49}$ Pará. Relatorio com que ao exm. sr. Dr. José da Gama Malcher, $1^{o}$. Vice-Presidente passou a administração da provincia do Pará o exm. sr. Dr. João Capistrano Bandeira de Mello Filho em 9 de março de 1878. Belém: Typ. Guttemberg, 1878. p. 68.

${ }^{50}$ Pará. Falla com que o exm. senr. Dr. José Joaquim do Carmo abrio a $1^{a}$. sessão da $21^{a}$. legislatura da Assembléa Legislativa da Provincia do Pará em 22 de abril de 1878. Belém: Typ. da Provincia do Pará, 1878. p. 5-6.

${ }^{51}$ Note-se aqui uma crítica direta ao governo dos conservadores. Ao afirmar que os recursos do Tesouro Provincial estavam sendo aplicados com "mais prudência", o Presidente não estava apenas fazendo um auto-elogio, mas censurando as administrações anteriores. Como ele havia assumido após a ascensão dos liberais, sua Fala era apresentada a uma Assembléia Provincial constituída por uma maioria de deputados conservadores. Ibidem. p. 11.

${ }^{52}$ Ibidem. p. 15.

${ }^{53}$ Pará. Falla com que o excellentissimo senhor Doutor José Coelho da Gama e Abreu Presidente da Provincia abriu a $2^{a}$. sessão da $21^{a}$. legislatura da Assembléa Legislativa da Provincia do Gram-Pará em 16 de junho de 1879. Belém: Typ. do Liberal do Pará, 1879, p. 33-49.

${ }^{54}$ Ibidem. p. 15.

${ }^{55}$ Ibidem. p.17-18.

${ }^{56}$ Ibidem. p. 67.

${ }^{57}$ Ibidem. p. 69.
} 
como desmatamentos, abertura de estradas e construção de pontes. ${ }^{58}$ A tendência de elevação das arrecadações seria confirmada pelo orçamento de $1881-1882,{ }^{59}$ mas o problema de escassez e carestia de alimentos, principalmente em Belém, não estava resolvido. ${ }^{60}$

Comparando os relatórios de Pedro Vicente de Azevedo e o de José Coelho da Gama e Abreu, percebemos uma mudança significativa no que se refere à avaliação dos administradores sobre o papel da borracha na economia local. Embora este último não tenha reavaliado o seu ponto de vista sobre qual seria o melhor caminho para se promover o desenvolvimento da Província, ou seja, o incremento da agricultura e o incentivo à imigração européia, seu relatório deixa transparecer que estes setores dependiam do bom desempenho da economia da borracha. Assim, embora Pedro Vicente de Azevedo e muitos outros presidentes culpassem a borracha pelo fraco desempenho da produção agrária da Província, eram suas exportações que ditavam o ritmo do desenvolvimento da Província e, consequentemente, alimentavam esperanças em relação ao futuro.

Muitos autores fizeram raciocínio semelhante ao de Pedro Vicente de Azevedo e dos demais críticos da borracha, responsabilizando-a pela decadência da economia do Vale Amazônico, em especial da agricultura. Manuel Barata, por exemplo, escrevendo em meio à chamada "grande decadência" da borracha, no início do século XX, fez um balanço da produção agrícola do Pará, desde o início do período colonial, para argumentar que era preciso abandonar o "fetichismo" do látex e voltar à cultura da terra e à exploração de outras fontes de riqueza. ${ }^{61}$ Algumas décadas mais tarde, Arthur Cezar Ferreira Reis, afirmou que, como a mão-de-obra era escassa, quase todos os braços disponíveis eram canalizados para a coleta e comercialização da borracha. Em razão disso, só restava ao Pará importar os alimentos consumidos pelos seringueiros e demais habitantes. $^{62}$

\footnotetext{
${ }^{58}$ Pará. Relatorio apresentado a Assembléa Legislativa Provincial na $2^{a}$. sessão da $22^{a}$. legislatura, em 15 de fevereiro de 1881, pelo exm. sr. dr. José Coelho da Gama e Abreu. Belém: Typ. do "Diario de Noticias", 1881.p. 30.

${ }^{59}$ Ibidem. p. 69-70.

${ }^{60}$ Ibidem. p. 124.

61 BARATA, Manuel. A antiga produção e exportação do Pará. Estudo histórico-econômico. In: Formação Histórica do Pará. Obras reunidas. Belém: Universidade Federal do Pará, 1973. p. 293-330.

${ }^{62}$ De acordo com o autor, os seringalistas puniam os trabalhadores que se desviavam das tarefas de extração do látex para qualquer outra empresa e o próprio seringueiro não se sentia atraído por uma
} 
À medida que nos distanciamos do período da "grande decadência" encontramos pontos de vista diametralmente opostos. No final da década de 1960, por exemplo, Antônio da Rocha Penteado, mesmo citando o relatório de Pedro Vicente de Azevedo, argumentou que a borracha proporcionou não apenas o incremento da produção agrícola como também a instalação de colônias de imigrantes e a construção da Estrada de Ferro de Belém a Bragança. ${ }^{63}$ Da mesma forma, e analisando especificamente o desempenho da economia da Amazônia, Roberto Santos afirmou que a partir de 1877 a tendência da renda interna se tornou "incontidamente crescente" até $1910 .^{64}$ De acordo com o autor, não houve um "declínio absoluto de todos os principais artigos registrados estatisticamente" no período anterior a 1872. O grande problema seria que a população da Amazônia aumentou muito entre 1848 e 1872, passando de 179.707 habitantes para 332.847. Assim, ao invés de culparem a borracha, os presidentes e intelectuais do período deveriam ter dito, segundo o autor, que o problema residia no fato de que os demais artigos tinham um ritmo de crescimento da produção inferior ao da população. ${ }^{65}$

$\mathrm{Na}$ verdade, este crescimento teria se iniciado em 1840, o que levou o autor a considerar o período que vai de 1840 a 1910 como a "fase de expansão da economia gomífera". Baseado nestas e em outras cifras, Roberto Santos se colocou contra duas interpretações correntes: a que ele designou de "ufanista", por valorizar o que a borracha proporcionou à Amazônia em termos de povoamento, ocupação territorial, ampliação da área física nacional, vivência cultural e artística; e a "radical-pessimista", constituída por aqueles não atribuem maior significado à economia gomífera e negam a contribuição da Amazônia ao desenvolvimento do país. ${ }^{66}$

atividade que não compensava tanto quanto a extração do látex. REIS, Arthur Cezar Ferreira. O Seringal e o Seringueiro. Rio de Janeiro: Ministério da Agricultura, 1953. p. 106-108.

${ }^{63}$ PENTEADO, António Rocha. Problemas de colonização e de uso da terra na região bragantina do Estado do Pará. Lisboa: Junta de Investigações do Ultramar, 1968. p. 54-58.

${ }^{64}$ A taxa anual de crescimento da renda interna da região no período de 1850 a 1900 , segundo o autor, foi da ordem de $5,4 \%$, enquanto o da economia cafeeira, de $2,3 \%$; a população teria aumentado de 200.391 para 695.112 habitantes, correspondendo a uma taxa de 2,6\% ao ano. Assim, a renda per capita teria avançado a um ritmo de $2,8 \%$, sendo que a do país como um todo estaria na ordem de $1,5 \%$. SANTOS, Roberto. Op. cit. p. 12; 298-299.

${ }^{65} \mathrm{O}$ autor analisou os relatórios dos presidentes de província indiretamente, ou seja, através da obra de Manoel Barata. Ibidem. p. 70-71; 283-285.

66 Roberto Santos não citou nomes de autores que classificou de "ufanistas"; quanto aos "radicaispessimistas" mencionou os de Celso Furtado e Caio Prado Júnior. 
A análise dos relatórios e falas dos presidentes de Província indica, contudo, que os administradores percebiam oscilações mais constantes, e não um crescimento incontido da produção e exportação de borracha. Eles percebiam, por exemplo, que a partir de 1877 a economia regional entrou em uma fase de crescimento acelerado, motivado pela elevação dos preços da borracha no mercado internacional e pela chegada de grandes levas de imigrantes nordestinos. Esta tendência seria duplamente revertida já a partir de 1883, com uma nova crise de preços e o aumento dos gastos públicos ocasionado pelo atendimento aos flagelados pela seca.

$\mathrm{O}$ ano de 1882 foi pródigo em falas e relatórios presidenciais. Manuel Pinto de Souza Dantas Fillho, ${ }^{67}$ João José Pedro, ${ }^{68}$ Justino Ferreira Carneiro ${ }^{69}$ e João Rodrigues Chaves ${ }^{70}$ ocuparam a administração da Província naquele ano e foram unânimes em assinalar a recuperação das finanças do Pará, embora alguns deles registrassem certa preocupação com o decréscimo na produção da borracha. João José Pedro, por exemplo, solicitou à Assembléia Provincial que fossem adotadas medidas para proteger os seringais. Por outro lado, assinalou que a fonte mais segura de riqueza era a agricultura, lamentando o fato de a prosperidade dos negócios da borracha provocar escassez de braços na lavoura. A solução, então, seria buscar braços fora da Província, mais "afeitos à vida segura com o trabalho agrícola”. Nesse sentido, pediu que a Assembléia destinasse recursos para a fundação e manutenção de colônias agrícolas. ${ }^{71}$

Os administradores se mostravam preocupados com a situação da agricultura local mesmo quando a economia da borracha dava sinais de recuperação. De acordo

${ }^{67}$ Pará. Relatorio com que o exm. sr. Presidente Dr. Manuel Pinto de Souza Dantas Filho passou a administração da provincia ao exm. sr. $1^{o}$. Vice-Presidente Dr. José da Gama Malcher. Belém: Typ. do Liberal do Pará, 1882. p. 105.

${ }^{68}$ Pará. Falla com que o exm. snr. Dr. João José Pedro abrio a $1^{a}$. sessão da $23^{a}$. legislativa da Assembléa Legislativa da Provincia do Pará, em 9 de abril de 1882. Belém: Typ. de Francisco da Costa Junior, 1882.

${ }^{69}$ Pará. Relatorio com que a sua exc. o sr. Dr. Justino Ferreira Carneiro passou a administração da provincia do Pará no dia 25 de agosto de 1882 o excmo. sr. Conselheiro João Rodrigues Chaves, $1^{\circ}$. Vice-Presidente da mesma provincia. Belém: Typ. do Commercio do Pará, 1882.

${ }^{70}$ Pará. Relatorio com que ao exm. sr. conselheiro João Rodrigues Chaves, passou a administração da provincia do Pará no dia 6 de dezembro de 1882 o excmo. sr. Conselheiro Justino Ferreira Carneiro. Belém: Typ. do Jornal da tarde, 1882.

71 Pará. Falla com que o exm. snr. Dr. João José Pedro abrio a $1^{a}$. sessão da $23^{a}$. legislativa da Assembléa Legislativa da Provincia do Pará, em 9 de abril de 1882. Belém: Typ. de Francisco da Costa Junior, 1882. p. 14. 
com Justino Ferreira Carneiro, ${ }^{72}$ por exemplo, a prosperidade dos negócios da borracha fazia aumentar o fluxo de pessoas para Belém, tornando ainda mais precária a obtenção de gêneros alimentícios, devido ao aumento da demanda. ${ }^{73}$ Para o Visconde de Maracajú, o problema estava na carestia dos gêneros alimentícios, que provocava a redução das rendas provinciais. $^{74}$ Já o conselheiro João Silveira de Souza responsabilizava apenas a queda do preço da borracha no mercado internacional pelos problemas financeiros da administração, ${ }^{75}$ embora afirmasse, em 1885 , que mesmo havendo grandes safras e bons preços naquele ano a situação não melhoraria devido à crise dos anos anteriores. ${ }^{76}$ Gentil Bittencourt, por sua vez, estimou que dois terços do total de impostos arrecadados sobre exportações provinham dos negócios da borracha. ${ }^{77}$

Ainda em 1885, João Lourenço Paes de Souza minimizou os efeitos da crise da borracha, afirmando que o papel do "estadista" era facilitar a "evolução natural da Província”, ou seja, promover uma eficiente classificação e distribuição da receita para os municípios. ${ }^{78}$ As rendas que a borracha gerava para os cofres da Província não teriam sofrido grande declínio porque o aumento da quantidade exportada compensara a baixa dos preços. ${ }^{79}$ Não obstante, reclamou providências para impedir o contrabando de borracha para Manaus. ${ }^{80}$

A afirmação de João Lourenço Paes de Souza de que o papel do Administrador era facilitar a "evolução natural" da Província não deve ser tomada ao pé da letra. Afinal, os relatórios e falas contêm um número expressivo de sugestões dos presidentes sobre medidas a serem tomadas para reverter o estado em que a Província se

\footnotetext{
${ }^{72}$ Pará. Relatorio com que a sua exc. o sr. Dr. Justino Ferreira Carneiro passou a administração da provincia do Pará no dia 25 de agosto de 1882 o excmo. sr. Conselheiro João Rodrigues Chaves, $1^{o}$. Vice-Presidente da mesma provincia. Belém: Typ. do Commercio do Pará, 1882.

${ }^{73}$ Ibidem. p. 19-21.

${ }^{74}$ Pará. Relatorio com que o exmo. snr. General Visconde de Maracajú passou a administração da provincia ao $2^{o}$. Vice-Presidente, exm. sr. dr. José de Araújo Roso Danin. Belém: Typ. de Francisco da Costa Junior, 1884. p. 5-16.

${ }^{75}$ Pará. Falla com que o exm. senr. conselheiro João Silveira de Sousa, abriu a $1^{a}$. sessão da $25^{a}$. legislatura da Assembléa Legislativa Provincial em 15 de outubro de 1884. Belém: Typ. de Francisco da Costa Junior, 1885. p. 17-18.

${ }^{76}$ Pará. Falla com que o exm. sr. conselheiro Dr. João Silveira de Souza, Presidente da Provincia do Pará, abrio a $2^{a}$. sessão da $24^{a}$. legislatura da Assembléa Provincial, em 18 de abril de 1885. Belém: Typ. da Gazeta de Noticias, 1885. p. 19-20.

${ }^{77}$ Ibidem. p. 88.

${ }^{78}$ Pará. Relatorio que ao exm. sr. dr. João Lourenço Paes de Souza $I^{o}$. Vice-Presidente da Provincia do Gram-Pará apresentou ao exm. sr. dr. Carlos Augusto de Carvalho, em 16 de setembro de 1885. Belém: Typ. de Francisco da Costa Junior, 1885. p. 31-32.

${ }^{79}$ Ibidem. p. 38.

${ }^{80}$ Ibidem. p. 45.
} 
encontrava. Entre estas medidas estava o incentivo para o desenvolvimento de outras atividades econômicas, principalmente a agricultura. Não se tratava, portanto, de promover apenas uma "eficiente classificação e distribuição" da receita pelos municípios, mas de fomentar a produção de gêneros alimentícios para abastecer o mercado interno e a exportação daqueles requeridos pelo mercado internacional, o que era uma diretriz estabelecida pelo Governo Imperial. Mas para isso era preciso, entre outras coisas, criar um mercado de trabalho estável, ou seja, um exército de reserva de mão-de-obra barata, disciplinada e dependente.

Nesse sentido, boa parte dos recursos da administração era investida na região de Bragança, que se destacava por sua produção agrícola. Além da instalação de colônias agrícolas, investia-se ali na abertura estradas de rodagem e de ferrovias, construção de pontes etc. Os recursos para tanto eram obtidos principalmente através da arrecadação de impostos, decorrentes da comercialização da borracha e de outros produtos naturais. De acordo com Tristão de Alencar Araripe, o desenvolvimento da viação terrestre possibilitaria uma exploração mais eficiente das riquezas existentes no interior e a fixação dos trabalhadores, uma vez que a Província era explorada por uma população erradia, sempre em busca dos produtos extrativos. ${ }^{81}$ Além disso, contribuiria para a redução dos fretes, que na sua opinião eram muito exagerados no Pará. ${ }^{82}$

Em sua fala na Assembléia Provincial em 1886, o desembargador Joaquim da Costa Barradas afirmou que a renda da Província suportava gastos normais, deixando ainda saldos razoáveis. ${ }^{83}$ Isto apesar da crise que atingia, naquele momento, os negócios da borracha. Todavia, recomendou que só fossem feitos melhoramentos de caráter reprodutivo. ${ }^{84}$ De acordo com o desembargador, o país e, principalmente, a região amazônica não deviam gastar dinheiro público com ensaios de colonização, mas incentivar a "imigração espontânea" e dar ao recém-chegado liberdade de escolha para se estabelecer onde quisesse. ${ }^{85}$

\footnotetext{
${ }^{81}$ Pará. Falla com que o Exm. Conselheiro Tristão Alencar Araripe, Presidente da Provincia do Pará, abriu a sessão extraordinária da Assembléa Legislativa Provincial no dia 5 de novembro de 1885. Belém:Typographia do Diario de Noticias, 1886. p. 7.

${ }^{82}$ Ibidem. p. 9-10.

${ }^{83}$ Pará. Falla com que o Exm. Snr. Desembargador Joaquim da Costa Barradas abriu a sessão extraordinaria da Assembléa Legislativa Provincial do Pará em 20 de novembro de 1886. Belém: Typ. do Diario de Noticias, 1887. p. 5.

${ }^{84}$ Ibidem. p. 6.

${ }^{85}$ Segundo ele, a lei do orçamento mantinha uma verba de 100 contos para tal serviço, mas a propaganda deveria mais eficaz. Ibidem. p. 14-15.
} 
Mais pessimista que seu antecessor, o conselheiro Francisco José Cardoso Junior assinalou que o estado da dívida pública inspirava graves apreensões e causava grandes embaraços à solução dos compromissos da Província. ${ }^{86}$ Seu ponto de vista foi reforçado por Miguel José d’Almeida Pernambuco, ${ }^{87}$ que enfatizou a importância da "ciência estatística" para o "aperfeiçoamento moral e político do indivíduo e da sociedade". De acordo com ele, era lamentável que a Província não dispusesse de dados relativos ao movimento cível e econômico da população, a exemplo do que ocorria em São Paulo, Rio de Janeiro e Ceará. ${ }^{88}$ Ao concluir seu relatório, afirmou que as finanças da Província continuavam em situação difícil. ${ }^{89}$

A desorganização do serviço público, a desonestidade de funcionários e a desconfiança da população em relação à força policial foram apontados por José de Araújo Roso Danin como os principais sintomas da crise que atingira a administração do Pará. ${ }^{90}$ Assim, não seria apenas a crise comercial que prejudicava o desenvolvimento regional, mas também o desvio criminoso das rendas. ${ }^{91}$ Embora menos enfático na avaliação que fez da situação da administração do Pará, Antônio José Ferreira Braga, último ocupante da presidência da Província antes da queda da Monarquia, enfatizou a necessidade de serem adotadas medidas salvá-la da crise em que se encontrava. ${ }^{92}$ Os principais fatores, segundo ele, eram a imprudência na organização do orçamento e a crise comercial. $^{93}$

Em suma, a análise dos relatórios e falas dos administradores do Pará demonstra que o período compreendido entre 1868 e 1889 foi marcado por uma série de dificuldades em relação às finanças provinciais. Afinal, as referências a uma possível prosperidade foram muito escassas, geralmente não ultrapassando um ou dois anos.

${ }^{86}$ Pará. Falla com que o exm. sr. conselheiro Francisco José Cardoso Junior, $1^{\circ}$. Vice-Presidente da Provincia do Pará, abrio a $1^{a}$. sessão da $26^{a}$. legislatura da Assembléa Provincial, no dia 4 de março de 1888. Belém: Typ. do Diario de Noticias, 1888. p. 28.

${ }^{87}$ Pará. Falla com que o exm. snr. D. Miguel José d'Almeida Pernambuco, Presidente da Provincia, abrio a $2^{a}$. sessão da $26^{a}$. legislatura da Assembléa Legislativa Provincial do Pará em 2 de fevereiro de 1889. Belém: Typ. de A. F. da Costa, 1889. p. 27.

${ }^{88}$ Ibidem. p. 105.

${ }^{89}$ Ibidem. p. 58.

${ }^{90}$ Pará. Relatorio com que o exm. sr. dr. José de Araujo Roso Danin $1^{o}$. Vice-Presidente da Provincia do Pará passou a administração da mesma ao exm. sr. Dr. Antonio José Ferreira Braga. Belém: Typ. de A. Fructuoso Costa, 1889, p. 5.

${ }^{91}$ Ibidem. p. 17.

${ }^{92}$ Pará. Relatorio com que o exm. sr. dr. Antonio José Ferreira Braga, Presidente da Provincia, abrio a sessão extraordinaria da $26^{a}$. legislatura da Assembléa Legislativa Provincial do Pará, em 18 de setembro de 1889. Belém: Typ. de A. Fructuoso da Costa, 1889, p. 4.

${ }^{93}$ Ibidem. p. 59. 
Sobressai, ainda, em momentos específicos, uma coincidência entre crise financeira e crise política, principalmente na inversão partidária de 1878 e nas vésperas do golpe militar que implantou o regime republicano no país. Naqueles momentos, as alusões dos presidentes a problemas administrativos se tornavam contundentes, deixando entrever possíveis conflitos políticos entre os representantes do Governo Imperial e a elite regional.

Não há evidências nos relatórios e falas dos presidentes que administraram a Província naquele período, que nos permitam afirmar que aqueles oriundos de outras regiões tinham menor conhecimento das dificuldades locais do que aqueles naturais da Amazônia, muito menos evidências de uma falta de continuidade administrativa. Ao contrário disso, encontramos insistentes referências à necessidade de se promover uma racionalização da máquina administrativa, ou seja, de evitar desperdícios e de aplicar de maneira mais produtiva e equilibrada possível os escassos recursos existentes; à necessidade de serem investidos recursos no incremento da produção agrícola e, conseqüentemente, na criação de núcleos coloniais e no incentivo à imigração espontânea.

O procedimento mais comum entre os administradores era o de apontar os problemas do presente e indicar caminhos para a prosperidade futura. Os males, como vimos, estavam geralmente relacionados com a dependência de todos os âmbitos da esfera pública e privada em relação ao desempenho de um único setor: o dos negócios da borracha. Vivia-se, assim, no inferno e no paraíso ao mesmo tempo. As exportações traziam a prosperidade: recursos para construção de estradas, pontes, edifícios públicos, monumentos, teatro, calçamento de ruas, novidades da moda de Paris etc. Mas traziam também a preocupação em relação ao futuro, pois a riqueza da borracha era considerada efêmera.

$\mathrm{Na}$ agricultura eram depositadas todas as esperanças de prosperidade no futuro. Só ela traria riqueza duradoura, que não ficaria limitada à cidade de Belém nem às áreas portuárias ou pequenos trechos das margens dos rios. Projetava-se, então, um cenário sombrio, supostamente o palco das preocupações da maioria dos administradores: quanto mais a economia da borracha prosperava, mais a agricultura definhava. Se essa imagem condizia com o real, pouco importava. O Administrador não se apresentava como alguém cuja missão fosse eliminar os males do presente, mas principalmente 
como aquele que devia lançar a semente do progresso. Este artifício lhe permitia cumprir a missão para a qual fora alçado à função que desempenhava: realizar no âmbito da província a política do gabinete ministerial ao qual servia.

Os políticos não assumiam o cargo de presidente de província apenas para facilitar a "evolução natural" desta, como afirmou um deles. É evidente que se isso fosse possível eles não relutariam em fazê-lo, mas sua principal missão era outra: estabelecer com as elites políticas locais um pacto de modo a tornar possível o sucesso da política do Gabinete que o havia nomeado. Esta condição o transformava, muitas vezes, em uma espécie de fiscal do Governo Imperial na província, como assinalaram alguns autores, mas também um negociador político. ${ }^{94}$ Assim, a canalização de recursos para a criação de núcleos coloniais, a contratação de agentes ou associações encarregados de introduzir imigrantes na província, construção de ferrovias, enfim, a ênfase na necessidade de desenvolvimento da agricultura, em detrimento do extrativismo, só ocorria da parte dos administradores provinciais porque satisfazia a interesses de uma parte expressiva das elites regionais.

\subsection{Café: o fiel da balança}

Várias distinções podem ser estabelecidas entre as Províncias de São Paulo e do Pará no período estudado. Entretanto, em se tratando das administrações provinciais, é possível encontrarmos algumas semelhanças. Se os administradores que governaram a Província do Pará entre 1868 e 1888 assinalavam a dependência das finanças públicas em relação ao desempenho da economia exportadora, o mesmo acontecia em São Paulo. Entretanto, diferentemente do que ocorria no Vale Amazônico, os administradores desta última não se mostravam preocupados com a produção de gêneros agrícolas de

\footnotetext{
${ }^{94}$ Há uma extensa produção no Brasil que enfatiza o caráter centralizador da política imperial e a dominação que uma elite dirigente sediada na região centro-sul exercia sobre as elites regionais. Em trabalhos recentes, como os de Miriam Dolhnikoff, ainda que voltados para um período um pouco anterior ao aqui estudado, encontramos afinidade maior com os resultados de nossas pesquisas. De acordo com esta autora, o projeto político das elites que controlavam o poder acomodava as reivindicações regionais em um arranjo nacional, estabelecendo, assim, um "pacto imperial". DOLHNIKOFF, Miriam. Elites Regionais e a Construção do Estado Nacional. Op. cit. p. 432; DOLNIKOFF, Miriam. O Pacto Imperial. Op. cit. p. 14-22. Entre as análises que enfatizaram a capacidade das elites do Rio de Janeiro de se imporem no cenário nacional, destacamos: CARVALHO, José Murilo de. A Construção da Ordem. A elite política imperial. Rio de Janeiro: Campus, 1980; e MATTOS, Ilmar Rohloff de. O Tempo Saquarema. A formação do Estado Imperial. São Paulo: Hucitec, 1990.
} 
subsistência. Além disso, em ambas as Províncias os presidentes defendiam a racionalização da máquina administrativa, e elegiam a formação de um mercado de trabalho e a abertura de estradas como necessidades cruciais para o desenvolvimento regional.

Em 1868, por exemplo, Joaquim Saldanha Marinho se mostrava preocupado com os sacrifícios de "sangue e dinheiro" impostos pela Guerra do Paraguai, porém, assinalou que sempre observara a lei e respeitara os direitos individuais, ainda que isto significasse ser "um pouco mais tardio" no envio dos contingentes. 95 De todas as “desastrosas e inevitáveis consequiências" que atribuía ao conflito no Prata, a que mais parecia preocupá-lo era a paralisação da agricultura e da "indústria" pela falta de braços.

Nesse sentido, embora considerasse o estado financeiro da Província "satisfatório", 96 Saldanha Marinho recomendou aos deputados provinciais que aprovassem medidas para reduzir as despesas de produção e transporte dos gêneros. Sugeriu, ainda, que eles procurassem saber quais eram os centros de maior produção agrícola da Província para, então, dotá-los de estradas regulares até às estações das ferroviárias. ${ }^{97}$ Não se devia, portanto, repartir os escassos recursos por todos ao mesmo tempo e sem conhecimento, sem cálculo, pois isso significaria atender apenas a interesses momentâneos e de particulares, prejudicando "descomunalmente" o interesse geral e verdadeiro: a prosperidade da Província. ${ }^{98}$

Uma dificuldade em lidar com os relatórios dos administradores de São Paulo é o fato de que eles nem sempre discriminavam a cafeicultura da produção de gêneros agrícolas de subsistência. Quando os presidentes solicitavam recursos e incentivos para favorecer a "lavoura" ou a "agricultura", eles provavelmente estavam se referindo à cafeicultura. No Pará, o contraste entre a principal atividade de exportação e a agricultura era mais evidente, o que muitas vezes dava a entender que os administradores estabeleciam uma oposição entre extrativismo e produção de alimentos. Em todo caso, os presidentes de São Paulo não mencionavam problemas de abastecimento de gêneros alimentícios, como ocorria freqüentemente no Pará.

\footnotetext{
${ }^{95}$ São Paulo. Relatorio apresentado à Assembléa Legislativa Provincial de São Paulo na primeira sessão da décima oitava legislatura, no dia 2 de fevereiro de 1868, pelo Presidente da mesma Provincia, o conselheiro Joaquim Saldanha Marinho. São Paulo: Typographia do "Ypiranga", 1868. p.6.

${ }^{96}$ Ibidem. p. 93.

${ }^{97}$ Ibidem. p. 32.

${ }^{98}$ Ibidem. p. 7.
} 
Coerentes com o raciocínio de Saldanha Marinho, os administradores que governaram a Província de São Paulo nos últimos anos da década de 1860 voltaram suas atenções principalmente para a guerra com o Paraguai e, no plano interno, para a construção e manutenção de estradas. De acordo com Francisco Doratioto, a dificuldade para o alistamento de soldados, que já era grande no início do conflito armado, tornouse ainda maior com a sua longa duração. Este problema teria sido parcialmente contornado através da libertação de escravos para lutar nos campos de batalha. Entretanto, como o escravo era a principal mão-de-obra utilizada cafeicultura, que passava por um período de grande expansão, criava-se outro problema, com o aumento da escassez de braços na principal atividade de exportação. ${ }^{99}$

Por vezes, o problema do recrutamento para a guerra aparecia, nos relatórios e falas dos presidentes, imbricado à "inversão partidária" de 1868, levou à substituição dos liberais pelos conservadores no Governo. Em 1869, por exemplo, o Senador Barão de Itaúna afirmou que, durantes as eleições, não enviara tropas para nenhuma localidade da Província, apesar de os liberais o acusarem de usar a força pública para garantir a vitória do governo no pleito. Para a guerra, remetera apenas 25 guardas nacionais e 72 recrutas, ao passo que um de seus antecessores, o liberal José Tavares Bastos, remetera 1.331 homens, não obstante a proibição de recrutamento em épocas de eleições. ${ }^{100}$

Ao invés de acusar seus adversários, o Presidente Antônio Cândido da Rocha preferiu aconselhar os deputados provinciais a ficarem mais atentos ao "movimento econômico" e se absterem de "especulações políticas e filosóficas”. Só assim, afirmou, a Província trilharia com mais segurança o caminho do progresso e da "civilização". 101 Apelando para o que chamou de "sentimento patriótico" dos deputados, o Administrador assinalou que a fertilidade das terras, a amenidade do clima e o amor ao trabalho que caracterizavam os paulistas, além de muitas outras "condições da futura

\footnotetext{
${ }^{99}$ De acordo com Francisco Doratioto, de novembro de 1866 a maio de 1867, dos 1331 paulistas enviados para o teatro da guerra, apenas 87 eram voluntários. Esta situação obrigou o governo provincial a ordenar às autoridades locais que atuassem com todo o rigor no recrutamento e na aquisição de voluntários. DORATIOTO, Franciso. Maldita Guerra. Nova história da Guerra do Paraguai. $2^{\mathrm{a}}$ reimpressão. São Paulo: Companhia das Letras, 2002. p. 255-276.

${ }^{100}$ São Paulo. Relatorio com que s. ex. o Senador Barão de Itaúna passou a administração da Provincia ao Exm. Sr. Commendador Antônio Joaquim da Rosa, $3^{o}$. Vice-Presidente. São Paulo: Typographia Americana, 1869. p. 3-4.

${ }^{101}$ São Paulo. Relatorio apresentado á Assembléa Legislativa Provincial de São Paulo pelo Presidente da Provincia o Exm. Sr. Dr. Antonio Candido da Rocha no dia 2 de fevereiro de 1870. São Paulo: Typographia Americana, 1870. p. 3.
} 
riqueza" da Província, necessitavam da solicitude dos mesmos para serem bem aproveitados.

A estratégia conciliatória deste último presidente pode ser explicada. O Barão de Itaúna deixara o cargo para ocupar seu assento no Senado, após a realização de duas eleições muito conturbadas, pois ocorreram poucos meses depois da "inversão partidária" de 1868. Em situações assim, os presidentes eram alvo de muitas críticas por parte dos políticos que até pouco tempo antes estavam no poder e também porque se utilizavam de expedientes, nem sempre lícitos, para garantir a vitória do Governo nas eleições. Daí o fato de o Barão de Itaúna utilizar seu relatório para responder a algumas das acusações que sofrera. Já Antônio Cândido da Rocha desempenhava aquela que seria a missão principal de um político na sua posição: negociar, com os deputados provinciais e demais forças políticas locais, acordos políticos que facilitassem a execução do programa de governo do Presidente do Conselho de Ministros. ${ }^{102}$

Segundo Sérgio Buarque de Holanda, ${ }^{103}$ o Barão de Itaúna foi nomeado Presidente da Província de São Paulo em 25 de julho de 1868, sendo substituído um ano depois. Entretanto, permaneceu no cargo apenas entre 27 de agosto e 24 de abril, justamente o período de preparação, realização e apuração das eleições, que resultaria na formação de uma Câmara composta apenas por deputados do Partido Conservador. Além disso, conseguiu que, dos seis vice-presidentes, ficasse em seu lugar o terceiro, preterindo os dois primeiros por não pertencerem à facção que o apoiava. Mas a partir de então, ainda haveria três substituições de vice-presidentes até a posse de Antônio Cândido da Rocha. Este intervalo entre a exoneração de um presidente e a nomeação de outro gerlamente era utilizado pelos vice-presidentes para acalmar os ânimos e estabelecer as bases para as alianças com os grupos que saíam vencedores nas eleições.

\footnotetext{
${ }^{102}$ Conforme assinalou Sérgio Buarque de Holanda, a missão dos presidentes era garantir o predomínio da orientação partidária no ministério no poder. Para tanto, escolhiam os chefes políticos reputados hábeis para decidir o resultado dos pleitos eleitorais, manobrar postos da Guarda Nacional, afastar elementos contrários ou suspeitos à situação dominante, conseguindo o seu recrutamento forçado para a tropa de linha ou, no momento em questão, para a guerra da Tríplice Aliança com o Paraguai, nomear autoridades policiais para as diferentes localidades, dispensando outras, atender às pretensões das pessoas que pudessem cooperar para o bom êxito de sua missão. Assim que esta terminava, os presidentes deixavam o cargo aos substitutos legais, quase sempre naturais ou habitantes da mesma província. Estas teriam sido as funções do Barão de Itaúna. As do seu substituto, Antônio Cândido da Rocha, parecem mais próximas da caracterização feita por Miriam Dolhnikoff: manter o pacto imperial, o arranjo político-institucional que integrava as províncias e dava sustentação ao regime monárquico. HOLANDA, Sérgio Buarque de. Do Império à República. Op. cit. p. 9; DOLHNIKOFF, Miriam. O Pacto Imperial. Op. cit. p. 117.

${ }^{103}$ HOLANDA, Sérgio Buarque de. Do Império à República. Op. cit. p. 9.
} 
Em seu relatório, Antônio Candido da Rocha não criticou os políticos adversários, mas o "serviço das estradas", que considerava precário, pois estava em sua quase totalidade confiado a funcionários escolhidos entre os fazendeiros que residiam nas regiões por onde elas passavam. Devido à grande extensão da Província e à falta de recursos da administração para contratar um número suficiente de engenheiros que pudessem dirigir e fiscalizar devidamente os trabalhos de abertura e conservação das estradas, o serviço de estradas estava entregue à funcionários que não possuíam habilitação profissional nem recebiam remuneração, apresentando-se muito aquém dos "mais comezinhos princípios da ciência da administração".

$\mathrm{Na}$ tentativa de solucionar estes problemas, o Presidente teria recomendado às Câmaras Municipais que formassem comissões, compostas de seus membros ou de pessoas de sua inteira confiança, a fim de verificar como estavam sendo despendidos os recursos públicos com o serviço das estradas, se os inspetores se mostravam "inteligentes e ativos" e se o traçado das mesmas era o mais conveniente. Entretanto, poucas Câmaras Municipais, segundo ele, prestaram as informações solicitadas, apesar de várias solicitarem da Administração Provincial recursos e providências para abertura e manutenção das estradas.

Diante disso, recomendou à Assembléia Provincial a subdivisão da Província em distritos e a nomeação de um engenheiro para cada um deles, os quais, residindo no ponto mais central da área administrada, percorressem freqüentemente o território, fazendo os exames, plantas e orçamentos que deveriam preceder as obras, além de fiscalizá-las. Esta providência, segundo ele, não era nova, pois estava prevista no artigo 36 da Lei $n^{\circ} .8$, de 19 de maio de 1862, mas caducara pela disposição do artigo 13 da Lei n. 16, de 21 de abril de 1863, visto não ter produzido os resultados para que fora criada. De acordo com o Presidente o problema estava na maneira como a lei fora executada, ou seja, dividira-se a Província em apenas três distritos com um engenheiro cada. Havia necessidade, portanto, de criar distritos menores e com mais de um engenheiro. Além disso, o sistema não excluía os inspetores, que poderiam auxiliar os engenheiros na realização de seu trabalho. Este sistema poderia resultar em diminuição dos gastos com estradas e na utilização mais racional das verbas votadas, o que 
implicava, também, em não destinar grandes recursos para regiões cuja produção não corresponderia a estes investimentos. ${ }^{104}$

Os presidentes de província dedicavam muito espaço nos relatórios para assuntos relacionados à abertura de estradas, principalmente no que se refere às ferrovias. Porém, esta questão transcende nossas preocupações, que estão mais voltadas neste capítulo para a análise que os administradores faziam da situação das províncias e a proposição de medidas para solucionar os problemas diagnosticados. Ao mencioná-la, contudo, quisemos assinalar algo percebido nos relatórios e falas dos presidentes do Pará e que nos parecem reforçar a idéia de que os administradores governavam as províncias executando determinadas políticas estabelecidas pelos ministérios a que serviam. Conforme observou Richard Graham, ${ }^{105}$ os proprietários rurais tinham opiniões ambivalentes sobre o Governo, ou seja, embora este fosse um instrumento eficaz para manter a subordinação dos pobres, também constituía uma ameaça à sua própria autoridade no interior. Para resolver o dilema, os homens de posses procuravam assegurar que eles mesmos, ou amigos seus, ocupassem cargos de poder em todos os níveis do aparato governamental.

A análise arguta de Richard Graham esclarece a questão a partir do ângulo do cidadão. Vista pelo ângulo do Administrador ela não se revelava tão simples. Ao assumirem suas funções, os presidentes de província sofriam pressões dos grupos locais para que colocassem em determinados postos gente de sua confiança. Antes mesmo que as "derrubadas" se tornassem públicas, através da publicação nos jornais de listas de remoções e nomeações de pessoas para ocupar os cargos disponíveis, uma acirrada batalha por postos na administração ocorria em praticamente todos os municípios das províncias. Nesse momento, uma escolha errada ou uma composição que não refletia a hegemonia local podia gerar problemas insolúveis e determinar, até mesmo, a substituição do Presidente.

Em razão disso, o item intitulado "Obras públicas" era um dos mais importantes dos relatórios presidenciais, pois continha descrições detalhadas dos gastos públicos, acompanhadas de justificativas e reflexões dos presidentes sobre o estado financeiro das províncias. De acordo com Antônio Cândido da Rocha, ${ }^{106}$ por exemplo, em todos os

\footnotetext{
${ }^{104}$ Ibidem. p. 14-17.

${ }^{105}$ GRAHAM, Richard. Op. cit. p. 67.

${ }^{106}$ Ibidem. p. 101-104.
} 
países as obras públicas davam lugar "aos mais sérios estudos" e constituíam "o mais importante ramo do serviço público", no qual eram realizados empreendimentos arrojados. Entretanto, o serviço de obras públicas no Brasil era "o mais imperfeito possível", devido ao pouco cuidado com que elas eram executadas. Isto apesar de o presente e o futuro se prenderem, segundo ele, ao maior desenvolvimento material do país.

Em São Paulo, particularmente, onde a "indústria", o comércio e a agricultura exigiam, segundo ele, o melhoramento dos meios de transporte para "arredarem de si os obstáculos que retardavam a sua prosperidade e máximo desenvolvimento”, as obras públicas consumiam muitos recursos sem apresentar resultados satisfatórios. As estradas eram em grande número, porém traçadas sem estudos que determinassem sua posição e suas vantagens. Disso resultava que entre dois lugares existiriam vários caminhos, todas eles em péssimo estado. $\mathrm{O}$ fato de os inspetores responsáveis por elas não terem habilitação para tanto, nem serem remunerados para executarem o serviço, agravava ainda mais o problema. Uma tentativa de solucioná-lo dera origem, em 1868, à Inspetoria Geral de Obras Públicas, mas esta repartição ainda não conseguira sequer fazer o levantamento dos “melhoramentos indispensáveis" às estradas, pois não contava com "pessoal habilitado, que exercesse sobre as obras a inspeção científica, que fizesse reparar em tempo os erros cometidos e que exercesse também a vigilância necessária na economia dos trabalhos".

Diante desse problema, comum a outros ramos da administração, Antônio Cândido da Rocha propôs que, ao contrário do que vinha sendo feito, não fosse entregue aos inspetores a quantia destinada a determinada obra; que elas não fossem mais realizadas "por administração", pois isso retardava sua conclusão e elevava os custos. Do sistema então adotado, o Presidente elogiou apenas o estabelecimento de contratos para execução das obras, mas lembrou que nem sempre se encontravam homens práticos e a tentativa dos contratantes de auferir grandes lucros afetava a qualidade delas. Além disso, faltavam, segundo ele, pessoas para fiscalizar os trabalhos.

A preocupação de Antônio Cândido da Rocha com a ingerência de particulares nos assuntos da administração pública e a falta de pessoal qualificado e idôneo para realizar a fiscalização de obras públicas não era um caso excepcional entre os presidentes de província. Ela denota uma clara concepção sobre a necessidade de serem 
separadas as esferas pública e privada, própria de uma concepção liberal de Estado. Segundo Maria Sylvia de Carvalho Franco, ${ }^{107}$ a partir de 1834 a organização administrativa passou a se fundar formalmente no princípio burocrático de obediência a um poder público abstratamente definido, legitimado e expresso por normas racionalmente criadas e legalmente estatuídas. Entretanto, a montagem de um corpo de agentes disciplinados, para o exercício metódico e despersonalizado das funções públicas, encontrava forte obstáculo no fato de que a conduta do servidor público orientava-se mais pelos vínculos que o prendiam aos interesses de seu meio social, que pela lealdade para com seu empregador distante e desmaterializado. Além disso, a montagem de uma máquina administrativa excessivamente centralizada, dada a necessidade de financiar o Governo Imperial e, portanto, carrear para ele a maior parte dos recursos arrecadados, deixava os municípios e províncias com parcos recursos.

Se, por um lado, os administradores da Província de São Paulo reclamavam da ingerência de particulares no serviço público, por outro lado, incentivava-os a buscar soluções para seus problemas sem esperar a ajuda do governo. Em 1872, numa referência à Comuna de Paris, o conselheiro Francisco Xavier Pinto Lima ${ }^{108}$ afirmou que a ordem pública em São Paulo era mantida devido o respeito ao princípio de autoridade e, também, em virtude do "gênio empreendedor" dos paulistas. Segundo ele, quando um povo se dedicava a "empresas grandiosas e a acometimentos arrojados", empenhando suas forças, atividade e recursos, nutrindo a íntima convicção de que o seu futuro bem-estar achava-se baseado principalmente no progresso da indústria e trabalhava com fervor para melhorá-la, não se devia temer que entre ele fossem “inoculadas" idéias subversivas que, em circunstâncias diversas, o levassem aos "mais abomináveis excessos".

A Província de São Paulo, segundo o Administrador, era dotada pela natureza de um clima "ameníssimo" e de uma "salubridade proverbial", situada em um solo de "prodigiosa uberdade", possuindo "excelentes ancoradouros", rios importantes, que a cortavam em direções variadas, e minerais de grande consumo e valor. A região necessitava que a "indústria moderna", auxiliada pelo progresso das ciências naturais,

${ }^{107}$ FRANCO, Maria Silvia de Carvalho. Homens Livres na Ordem Escravocrata. $3^{\text {a }}$ ed., São Paulo: Kairós, 1983. p. 112-116.

${ }^{108}$ São Paulo. Relatorio com que o Exm. Sr. Conselheiro Francisco Xavier Pinto Lima passou a administração da Provincia ao Exm. Sr. Dr. João Theodoro Xavier, Presidente da mesma. S. Paulo: Typ. Americana, 1872. p. 4-5. 
explorasse suas infinitas riquezas. Essa "indústria" começava a manifestar-se e os paulistas, cujo caráter empreendedor era atestado por sua "gloriosa história", sempre ávidos de progresso, procuravam com fervor aplicá-la em seus diversos ramos.

Entre essas empresas, ele mencionou a Companhia Paulista de Estradas de Ferro, a Companhia Ituana, a Companhia Sorocabana e a Companhia São Paulo e Rio de Janeiro, bem como as que construiriam os prolongamentos das vias férreas existentes e a abertura de novas. Mencionou ainda as explorações de minerais de diversas espécies. Enfim, havia, segundo ele, um verdadeiro "espírito de associação" em São Paulo, que tinha por objetivo promover o progresso e desenvolvimento da indústria. Este espírito de associação estreitava as relações entre os cidadãos, ligando-os pela comunidade de interesses, proporcionando trabalho honesto e lucrativo a milhares de indivíduos que antes permaneciam desocupados. Além disso, exercia sobre o povo uma influência "benéfica e moralizadora", incutindo idéias novas e "civilizando-o", que contribuiria para a permanência da ordem e tranqüilidade pública.

Contudo, o item "Obras Públicas", deixava claro porque o Presidente incentivava o "espírito de associação" dos paulistas: a situação dos cofres provinciais era tão grave que seu antecessor fora obrigado a contrair um grande empréstimo, para saldar as dívidas da Província. ${ }^{109}$ Não obstante, logo ao assumir a presidência, Francisco Xavier Pinto Lima teve de contrair novo empréstimo para efetuar o pagamento do Corpo Policial Permanente e dos Empregados Públicos, bem como para pagar os juros garantidos pela Província às Companhias Paulista, Ituana e Sorocabana, adiando, assim, a realização de várias obras públicas.

Segundo Ilmar R. de Mattos, ${ }^{110}$ a elite imperial procurava fazer com que os homens livres do Império se reconhecessem e se fizessem reconhecer como pertencentes a uma comunidade particular, estabelecendo um jogo de semelhanças e oposições que conduzia a uma exageração: o Brasil teria sido predestinado pela Providência para ser o centro das transações comerciais de todo o "mundo civilizado". Tratar-se-ia da manifestação de um sentimento de brasilidade que conjugava nativismo e patriotismo, ou seja, um sentimento de afeto pela natureza do país e pela jovem nação. Esta exageração, segundo o autor, cumpria o papel de pôr em relevo um determinado corpo político, assim como o Monarca ilustrado que o governava, mascarando a

\footnotetext{
${ }^{109}$ Ibidem. p. 22-23.

${ }^{110}$ MATTOS, Ilmar Rohloff de. Op. cit. p. 11-18.
} 
restauração do pacto colonial em bases novas: contraditoriamente, a manutenção da dependência em relação às "nações civilizadas", em especial a Inglaterra, era condição necessária para a sobrevivência da elite imperial.

A análise de Ilmar R. Mattos nos ajuda a compreender a comparação estabelecida por um Presidente da Província de São Paulo entre a suposta ordem reinante no país e a anarquia que imperou em Paris durantes os dias da Comuna. Tratava-se de ressaltar que, a despeito de vários problemas, o Brasil não estava envolvido numa luta fratricida e que, se as instituições brasileiras ainda não eram tão democráticas como as dos países ditos civilizados, pelo menos não haviam custado o sangue de seus cidadãos. Cumpriam a mesma função - de inverter a relação de dominação que os países "civilizados" exerciam sobre o Brasil - os elogios à posição geográfica privilegiada e às riquezas naturais da região, ao espírito de iniciativa dos paulistas e, principalmente, à associação entre civilização e agricultura, muito recorrente nos relatórios e falas dos presidentes. Esta associação, conforme observou o autor, denotava um apego às idéias fisiocratas, em contraposição a um mercantilismo declinante, identificado com a antiga Metrópole.

A análise do item "Obras Públicas" nos relatórios presidenciais nos permite perceber, ainda, o bom desempenho da economia cafeeira, a despeito das reclamações sobre o estado em que se encontravam as finanças públicas. Em 1873, por exemplo, o Presidente João Theodoro Xavier iniciou seu relatório exatamente com este item, o que deixava transparecer a recuperação da economia local, após uma crise da cafeicultura. ${ }^{111}$ Contrastava, segundo ele, o progresso das estradas de ferro com a decadência de todas as outras obras públicas. A vitalidade concentrara-se com exuberância em um ponto, deixando "desfalecer a máxima parte do corpo coletivo". O problema principal, de acordo com o Administrador, era o predomínio do "elemento mercantil", ou seja, dezenas de contos teriam sido entregues a encarregados de estradas e pontes sem que estes prestassem contas nem fornecessem informações sobre o destino dado a esta verba.

Considerando-se que a construção de estradas de ferro estava diretamente relacionada com a expansão da cafeicultura na Província, a preocupação do

111 São Paulo. Relatorio apresentado á Assembléa Legislativa Provincial pelo Exm. Sr. Dr. João Theodoro Xavier, Presidente da Provincia, no dia 5 de fevereiro de 1873. São Paulo: Typographia Americana, 1873. p.3. 
Administrador com o progresso desse setor e o atraso de outros revela que, assim como acontecia no Pará, os recursos provenientes da economia exportadora eram utilizados para financiar o desenvolvimento de outros. Portanto, a função econômica dos presidentes de província não parecia ser apenas a de carrear recursos para o Governo Imperial, mas também promover um equilíbrio entre as atividades de forma que umas não se desenvolvessem em detrimento de outras. Nesse sentido, João Theodoro Xavier criticava o desperdício de recursos públicos, isto é, a prática clientelista adotada por administrações anteriores.

No ano seguinte, demonstrando mais otimismo, João Theodoro Xavier comunicou aos deputados, com "sumo prazer", o "movimento ascensional" da Província e o "estado florescente" de sua "vida econômica". ${ }^{112}$ Dentre os serviços públicos realizados, segundo o Administrador, sobressaíam os "mais intimamente" ligados à "ordem material", à viação terrestre e fluvial, à "fecundidade nas indústrias fisiocráticas", ao progresso das rendas e às "condições estáveis de sua existência". 113 Todavia, assinalou que a situação favorável do Tesouro Provincial não se devia à economia no emprego dos recursos públicos, mas ao aumento das rendas devido, em grande parte, ao aumento das exportações de café.

A comparação entre o desempenho da economia das Províncias do Pará e de São Paulo, através dos relatos dos presidentes, revela uma coincidência entre períodos percebidos como de crise e de prosperidade. Isto era natural devido à dependência econômica dessas regiões em relação às flutuações do mercado internacional, embora em São Paulo a ação do clima, provocando fortes geadas, também podia contribuir para períodos de crise. Em todo caso, os inícios das décadas de 1870 e 1880 foram relatados como sendo de crise em ambas as Províncias, seguindo-se a eles um período de prosperidade.

Indiferentes, neste aspecto, a estas oscilações, os administradores atentavam para a necessidade de serem desenvolvidas outras atividades, além daquelas envolvidas com a economia exportadora, e também para o aperfeiçoamento destas. Em 1870, por exemplo, Antônio Cândido da Rocha lamentou que os fazendeiros, em geral, ainda não

\footnotetext{
${ }^{112}$ São Paulo. Relatorio apresentado a Assembléa Legislativa Provincial de S. Paulo pelo Presidente da Provincia João Theodoro Xavier no dia 5 de fevereiro de 1874. São Paulo: Typographia Americana, 1874.

${ }^{113}$ Ibidem. p. 3.
} 
tivessem abandonado o "rotineiro custeio e amanho das terras", nem conhecessem os instrumentos e máquinas que a indústria moderna desenvolvia. ${ }^{114}$ Entretanto, se por um lado a "arte da lavoura" estava praticamente estacionada, a produção agrícola da Província crescia de maneira "espantosa". Como forma de evitar que a prosperidade dependesse apenas do desempenho da atividade exportadora, o Administrador defendeu a criação de escolas agrícolas, que colocassem os lavradores "a par dos conhecimentos especiais de sua profissão" e fizessem com que eles aprendessem como empregar instrumentos agrícolas mais modernos e aperfeiçoados nas suas lavouras. ${ }^{115}$ Outra providência a ser tomada era a criação de um banco de crédito, que os libertasse dos pesados ônus a que estavam sujeitos nas mãos de comissários e capitalistas.

Alguns meses mais tarde, no entanto, Antônio da Costa Pinto e Silva fez um retrato radicalmente oposto do fazendeiro de São Paulo. ${ }^{116}$ Ele não seria mais, em geral, o "emperrado rotineiro" de alguns anos antes, pois empregava na sua lavoura não só os instrumentos importados, como procurava inventar outros mais apropriados ao solo e cultura locais, pois sabia ser esta uma forma de "poupar" braços, que além de escassos e, portanto, dispendiosos, eram também "imperfeitos". Poucos fazendeiros importantes não usavam o arado para o "amanho da terra" e para as plantações, bem como meio de fertilização dos terrenos cansados dos antigos cafezais. O uso de máquinas de beneficiamento contribuiria, ainda, para a melhoria da qualidade do café exportado, igualando-se em qualidade, naquele momento, ao café produzido no Rio de Janeiro.

O Administrador lembrou que o preço do café nos mercados de exportação dependia principalmente da sua qualidade, a qual era determinada pelo maior ou menor

\footnotetext{
${ }^{114}$ São Paulo. Relatorio apresentado á Assembléa Legislativa Provincial de São Paulo pelo Presidente da Provincia o Exm. Sr. Dr. Antonio Candido da Rocha no dia 2 de fevereiro de 1870. São Paulo: Typographia Americana, 1870. p. 41-42.

${ }^{115}$ Mas não era apenas nos momentos de crise que os administradores se preocupavam com o progresso das práticas existentes. Alguns anos mais tarde, Sebastião José Pereira propôs a criação de um "centro técnico", formado por jovens egressos de cursos de engenharia, cuja finalidade seria de assessorar a administração a planejar as obras, fiscalizar a sua execução, bem como a aplicação dos recursos públicos a elas destinados. De acordo com o Presidente, a administração pública devia progredir da mesma forma que a agricultura, o comércio, a indústria e as relações sociais. Assim, para que as estreitas e toscas pontes, as apertadas e íngremes estradas pudessem ser substituídas por obras públicas condizentes com o progresso da província seria necessário que a administração pública pudesse contar com pessoal qualificado. São Paulo. Relatorio apresentado á Assembléa Legislativa Provincial de S. Paulo pelo Presidente da Provincia o Exm. Sr. Dr. Sebastião José Pereira em fevereiro de 1877. São Paulo: Typ. do Diário, 1877. p. 35-36.

${ }^{116}$ São Paulo. Relatorio apresentado á Assembléa Legislativa Provincial de São Paulo pelo Presidente da Provincia o Exm. Sr. Dr. Antonio da Costa Pinto Silva no dia 5 de fevereiro de 1871. São Paulo: Typographia Americana, 1871. p. 42.
} 
cuidado com que era beneficiado. A melhoria verificada em São Paulo se devia a dois fatores: o maior cuidado com o beneficiamento do produto, em razão da impossibilidade ou dificuldade de aumentar o número de braços na lavoura; e a introdução das máquinas americanas Lidgerwood no processo de beneficiamento. Outro fator importante era a divisão do trabalho, princípio este que, segundo o Presidente, era adotado em países como o Ceilão e já conhecido e praticado em São Paulo. ${ }^{117}$

É difícil explicar esta mudança tão brusca de opinião do Administrador sobre o comportamento dos fazendeiros paulistas em relação ao emprego de máquinas, equipamentos e técnicas aperfeiçoadas. Sobressai na sua avaliação, contudo, a preocupação em associar a modernização da agricultura com a questão do suprimento de braços para as lavouras. Embora tenha publicado seu segundo relatório nos primeiros meses de 1871, o Presidente tinha conhecimento da tramitação do projeto de lei que resultaria na libertação dos filhos de escravos, em setembro daquele ano. Como a criação de escolas agrícolas só traria resultados a médio e longo prazo, o emprego de inovações técnicas e mecânicas poderia contribuir de forma mais imediata para a economia de mão-de-obra. Outra medida seria a associação entre os fazendeiros para promover a introdução de braços na Província. ${ }^{118}$

Reforçando a análise de seu antecessor, Francisco Xavier Pinto Lima ${ }^{119}$ lembrou que, até pouco tempo antes, os fazendeiros paulistas confiavam apenas na "prodigiosa força vegetativa do solo e na amenidade do clima", limitando-se ao processo de derrubar, queimar, plantar e colher. Da mecânica agrícola, eles conheceriam apenas "o indolente e rudimentar monjolo" e o "moinho de moer a cana" para o fabrico do açúcar. Entretanto, já começavam naquela data a compreender a utilidade de substituir esses "processos imperfeitos" por outros mais racionais, como os arados que a indústria moderna "descobria" e que com vantagem contribuíam para o aperfeiçoamento dos produtos e para a economia de tempos e de braços. Assim, já não seria raro ver "a

\footnotetext{
${ }^{117}$ São Paulo. Relatorio apresentado á Assembléa Legislativa Provincial de S. Paulo pelo Presidente da Provincia o Exm. Sr. Dr. Antonio da Costa Pinto Silva no dia 5 de fevereiro de 1871. S. Paulo: Typ. Americana, 1871. p.42-43.

${ }^{118}$ Concluindo sua análise, o Administrador afirmou que o estado da agricultura da província não era decadente, mas nem por se devia considerá-la como "completamente desassombrada" dos perigos que poderiam surgir com a falta de braços. A solução, segundo ele, era libertar o cidadão da tutela governamental. Ibidem. p.42-44.

${ }_{11}$ São Paulo. Relatorio com que o Exm. Sr. Conselheiro Francisco Xavier Pinto Lima passou a administração da Provincia ao Exm. Sr. Dr. João Theodoro Xavier, Presidente da mesma. S. Paulo: Typ. Americana, 1872. p.15-16.
} 
pesada, a preguiçosa enxada" ser substituída por arados e cultivadores americanos, movidos por um ou dois animais e guiados por dois homens de "mediano desenvolvimento muscular", que faziam o serviço de vinte trabalhadores "robustos e ativos". Não era raro, também, segundo o Presidente, serem vistas máquinas de vapor "bem montadas" aplicadas aos trabalhos que exigiam o café, a cana-de-açúcar e o algodão. Muitas fazendas possuíam "maquinismo aperfeiçoado" para socar, ventilar, polir e separar o café, bem como para descaroçar e enfardar o algodão. ${ }^{120}$

Assim, não obstante a crise, o Administrador concluiu que a agricultura entrava em uma nova fase, "inteiramente animadora”. Os problemas estariam, então, limitados a dois: a falta de capitais e de braços. Em relação à primeira, o Presidente propôs a criação de um banco rural, que oferecesse aos agricultores os capitais que necessitava, “a baixo premio e a prazos longos", mediante as condições precisas para segurança da divida principal e dos respectivos prêmios. Como um projeto nesse sentido já teria sido apresentado à Assembléia Legislativa Provincial, o Administrador solicitou o empenho dos deputados para sua aprovação. Quanto à falta de braços, afirmou que, apesar da introdução de máquinas modernas, havia uma "infinidade de serviços" que só podiam ser executados por braços humanos. A solução mais eficaz, portanto, segundo ele, era adotar meios urgentes de atrair para a Província "bons trabalhadores estrangeiros" e em número tal que pudessem, "com vantagem", suprir a falta da escravatura, que logo deixaria de existir. $^{121}$

O Governo Imperial estaria auxiliando a introdução de "colonos", subvencionando as pessoas ou associações que se dedicavam a esse "utilíssimo serviço". Em São Paulo, duas medidas teriam sido tomadas: a fundação da Sociedade Auxiliadora da Colonização e promulgação de uma lei provincial, em 1871, ampliada por uma disposição do ano seguinte, para facilitar a contratação de colonos pelos proprietários rurais. ${ }^{122}$ Além disso, a fertilidade do solo da Província, a salubridade de seu clima e a excelência de suas instituições também contribuiriam para atrair

\footnotetext{
${ }^{120}$ Segundo Thomas H. Holloway, na década de 1870 foram inventadas máquinas avançadas para retirar a polpa externa das cerejas antes da secagem, quebrar a casca dos grãos secos, separar o café por tipo e tamanho etc. Algumas destas operações não eram feitas anteriormente, como o despolpamento, enquanto outras eram muito lentas. HOLLOWAY, Thomas H. Imigrantes para o Café. Café e sociedade em São Paulo, 1886-1934. Tad. Eglê Malheiros. Rio de Janeiro: Paz e Terra, 1984. p. 58.

${ }^{121}$ São Paulo. Relatorio com que o Exm. Sr. Conselheiro Francisco Xavier Pinto Lima passou a administração da Provincia ao Exm. Sr. Dr. João Theodoro Xavier, Presidente da mesma. S. Paulo: Typ. Americana, 1872. p.16.

${ }^{122}$ Ibidem. p.17.
} 
imigrantes. Segundo o Administrador, alguns fazendeiros já haviam feito muito "nesse louvável empenho" e poderiam auxiliar a Assembléia Provincial no mesmo sentido. ${ }^{123}$

Mas a modernização da Província também teria o seu reverso. Em 1876, Sebastião José Pereira afirmou que os poderes públicos deviam controlar a iniciativa individual, dando-lhe direção conveniente, uma vez que o "entusiasmo" verificado em São Paulo podia arrastar a província para um precipício. ${ }^{124}$ Nesse sentido, reivindicou dos deputados proteção às "empresas úteis e de auspicioso futuro," embora não deixasse claro quais seriam. ${ }^{125}$ Quanto às ferrovias, embora conduzissem o progresso e a civilização, haviam deixado a Província em difícil situação financeira, pois a renda ordinária não supria o Tesouro com numerário suficiente para a solução dos encargos, o que obrigava a administração a suspender todas as despesas que pudessem ser dispensadas sem grave prejuízo do serviço público. De acordo com Sebastião José Pereira, todos os empréstimos contraídos na sua administração haviam sido feitos para pagar dívidas relativas à abertura e manutenção das estradas de ferro. ${ }^{126}$

A análise do relatório de Sebastião José Pereira completa aquela que vínhamos desenvolvendo sobre as relações entre os presidentes de província e as elites políticas provinciais. A preocupação dos administradores em afastar a ingerência dos fazendeiros no serviço de estradas - que não se restringia a este, mas a vários outros ramos da administração - não significava que os presidentes preconizassem uma concepção liberal de Estado plenamente acabada, ou seja, baseada, entre outras coisas, num princípio burocrático de obediência a um poder público abstratamente definido, legitimado e expresso por normas racionais e legalmente estatuídas, como assinalou Maria Sylvia de Carvalho Franco. ${ }^{127}$ Como agentes do Governo Imperial nas províncias, os presidentes buscavam, mais exatamente, promover a integração das elites provinciais - ou de alguns setores delas - ao Estado nacional, porém de forma controlada e limitada. Assim, se por um lado os presidentes defendiam o fim da intervenção dos fazendeiros na sua administração, por outro, era para eles que diria sua atenção,

123 São Paulo. Relatorio com que o Exm. Sr. Conselheiro Francisco Xavier Pinto Lima passou a administração da Provincia ao Exm. Sr. Dr. João Theodoro Xavier, Presidente da mesma. S. Paulo: Typ. Americana, 1872. p.17.

${ }^{124}$ São Paulo. Relatorio apresentado á Assembléa Legislativa Provincial de S. Paulo pelo Presidente da Provincia Exm. Sr. Dr. Sebastião José Pereira em 2 de fevereiro de 1876. São Paulo: Typ. do Diário, 1876.

${ }^{125}$ Ibidem. p. 13.

${ }^{126}$ Ibidem. p. 87-89.

${ }^{127}$ FRANCO, Maria Silvia de Carvalho. Op. cit. p. 112-116. 
promovendo, entre outras coisas, meios para que contassem com uma força de trabalho numerosa, disciplinada e dependente.

A partir de 1877 , os presidentes passaram a se mostrar mais otimistas em relação ao futuro da economia da Província de São Paulo. O próprio Sebastião José Pereira afirmou que o "elemento principal", senão único, da prosperidade e riqueza de São Paulo era a agricultura, pois contribuía para o desenvolvimento do comércio, a expansão da malha ferroviária e para a satisfação de várias necessidades do serviço público. ${ }^{128}$ Nesse sentido, os administradores deveriam auxiliá-la, removendo seus obstáculos, sobretudo a dependência em relação ao trabalho escravo, já condenado pela civilização. Somente a colonização e a imigração salvariam a agricultura, desviando a "tempestade", que estaria iminente.

Entretanto, de nada adiantaria atirar o imigrante isolado em meio às florestas virgens. Se a sua ambição era ser proprietário, devia ser satisfeita, ou seja, deviam-se facilitar os meios para que adquirisse a propriedade territorial, em lugares que pudesse achar fácil consumo dos frutos do seu trabalho. Uma vez estabelecido, devia-se deixá-lo "reger por si, desembaraçado de qualquer tutela". ${ }^{129}$ Nesse sentido, enviara uma representação ao Ministro da Agricultura, recomendando a fundação de núcleos coloniais nas proximidades da capital da Província e outras localidades para as quais eram fáceis os meios de comunicação. Em resposta à sua solicitação, o Ministro teria enviado uma comissão para medir os terrenos devolutos existentes no município de Sorocaba, próximos à fábrica Ypanema, e autorizado a presidência da Província a adquirir duas fazendas pertencentes ao mosteiro de São Bento, que seriam divididas em lotes para os imigrantes. ${ }^{130}$

Em 1879, dois meses após assumir a Administração Provincial, o Barão de Três Rios apresentou em seu relatório um anexo, ${ }^{131}$ contendo um análise do Inspetor do

\footnotetext{
${ }^{128}$ São Paulo. Relatorio apresentado á Assembléa Legislativa Provincial de S. Paulo pelo Presidente da Provincia o Exm. Sr. Dr. Sebastião José Pereira em fevereiro de 1877. S. Paulo: Typ. do Diário, 1877. p.87-88.

${ }^{129}$ Ibidem. p.88.

${ }^{130}$ Ibidem. p.89.

131 São Paulo. Relatorio apresentado a Assembléa Legislativa Provincial de São Paulo pelo $2^{\circ}$. VicePresidente da Provincia Exm. Sr. Barão de Três Rios no dia 2 de fevereiro de 1879. São Paulo: Typ. de Jorge Seckler, 1879.
} 
Tesouro Provincial, Laurindo Abelardo de Brito, ${ }^{132}$ que por sinal assumiria a presidência da Província alguns meses mais tarde. De acordo com seus dados, a receita da Província aumentava devido o progresso de "todas as suas indústrias", principalmente a cultura do solo, esta última devedora da iniciativa particular, da "índole dos paulistas" e da fertilidade das terras. Mas nem por isso autorizava que se gastasse além da média da arrecadação dos três últimos exercícios.

Não obstante, em seu primeiro relatório como Presidente da Província, Laurindo Aberlardo de Brito avaliou que o estado financeiro da Província de São Paulo carecia da "mais desvelada atenção por parte do Governo", 133 pois afetava toda a economia da ação administrativa. Dois anos antes, uma comissão examinar o Tesouro Provincial e identificado alguns "vícios e irregularidades", que não teriam ainda desaparecido devido a dependência do Governo de medidas legislativas que o habilitassem a reorganizar a economia daquele serviço. Laurindo de Brito reconhecia que os problemas haviam diminuído sensivelmente, sobretudo porque já se podia, a qualquer momento, conhecer a situação das finanças provinciais. Todavia, argumentou que ainda havia muito que realizar, pois as "práticas inveteradas" em qualquer ramo administrativo não cediam facilmente às "medidas da ordem e sistema legais", entre outras coisas devido ao fato de se tratar de uma "repartição" que se ramificava por uma vasta Província, cujo "enorme desenvolvimento" complicava e estendia o serviço público e dificultava a eficácia das tentativas de reorganizá-lo. ${ }^{134}$

De acordo com Laurindo de Brito, a repartição encarregada da administração e arrecadação das rendas provinciais exigia uma "reorganização eficaz", tanto na “distribuição harmônica dos serviços”, que por ela eram expedidos, como no pessoal que a serviam. Os serviços acompanhavam o desenvolvimento progressivo da Província, cresciam e se complicavam, trazendo como consequiência a necessidade de uma "escrituração especial" e exigindo maior atividade da parte dos funcionários. ${ }^{135}$

\footnotetext{
${ }^{132}$ São Paulo. Relatorio apresentado ao Illm. E Exm. Snr. Barão de Três Rios, Vice-Presidente da Provincia de S. Paulo, pelo Inspetor do Thesouro Provincial, Laurindo Abelardo de Brito. Santos: Typographia a vapor do Diário de Santos, 1879.

${ }^{133}$ São Paulo. Relatorio apresentado a Assembléa Legislativa Provincial de S. Paulo pelo Presidente da Provincia Laurindo Abelardo de Brito no dia 5 de fevereiro de 1880. Santos: Typ.do Diário de Santos, 1880. p.6.

${ }^{134}$ São Paulo. Relatorio apresentado a Assembléa Legislativa Provincial de S. Paulo pelo Presidente da Provincia Laurindo Abelardo de Brito no dia 5 de fevereiro de 1880. Santos: Typ.do Diário de Santos, 1880. p.6.

${ }^{135}$ Ibidem. Loc. Cit.
} 
Entre os problemas apontados pelo Administrador estava o fato de o pessoal empregado no Tesouro Provincial ser o mesmo que ali trabalhava desde 1868, assim como a distribuição dos serviços ser, com exceção de pequenas modificações, a mesma estabelecida no Regulamento de 20 de abril daquele mesmo ano. Portanto, enfatizava Laurindo Abelardo de Brito, a reorganização daquele "importante ramo da ação administrativa" impunha-se como uma "necessidade imperiosa" e imediata. Laurindo de Brito solicitou então aos legisladores que aprovassem medidas autorizando o Governo provincial a promover a reforma daquele serviço. ${ }^{136}$

No início da década de 1880, o preço do café no mercado internacional voltou a cair, mas, segundo Manoel Marcondes de Moura e Costa, o estado financeiro da Província não era desanimador. O aumento da safra do produto e o crescimento de outras fontes de renda estariam compensando a baixa do preço do principal produto de exportação. Além disso, havia grandes estoques em virtude das interrupções ocorridas no trânsito das estradas de ferro da Província, motivadas por grandes chuvas. ${ }^{137}$ Dois anos se passaram e o Barão de Guajará fez uma análise pessimista sobre as finanças da Província. O desequilíbrio entre a receita e a despesa era o principal fator de preocupação do Administrador, que apelou para o "patriotismo" dos deputados provinciais, solicitando que eles apoiassem sua administração. ${ }^{138}$

As preocupações deste Presidente, que por sinal era natural da Província do Pará, foram reiteradas pelo Inspetor do Tesouro provincial, durante o governo de Francisco Antônio de Souza Queiroz Filho. De acordo o Inspetor, a receita ordinária do orçamento provincial, reforçada por dois empréstimos que haviam sido contraídos, bastava apenas para cobrir os encargos da Província. A situação só não era pior, porque o "serviço de imigração" não tivera o desenvolvimento esperado, apesar de a despesa com ele ter aumentado em relação ao exercício anterior, e, principalmente, devido aos

\footnotetext{
136 Ibidem. p.7.

${ }^{137}$ São Paulo. Relatorio com que passou a administração da Provincia de S. Paulo ao Exm. Presidente Conselheiro Francisco de Carvalho Soares Brandão o Vice-Presidente Manoel Marcondes de Moura e Costa. S. Paulo: Typ. de Jorge Seckler, 1882. p.16-17.

${ }^{138}$ São Paulo. Falla dirigida a Assembléa Legislativa Provincial de S. Paulo na abertura da $1^{a}$ Sessão da $25^{a}$ legislatura Em 16 de janeiro de 1884 pelo Presidente Barão de Guajará. S. Paulo: Typ. da Gazeta Liberal, 1884. p.88.
} 
cuidados tomados por Francisco Antônio de Souza Queiroz Filho na administração da Província, mantendo a receita e a despesa nos mesmos patamares da gestão anterior. ${ }^{139}$

As rendas gerais da Província continuaram em queda, devido, em grande parte, aos prejuízos com a crise do café. ${ }^{140}$ Em 1887, o Barão de Parnahyba registrou um decréscimo na safra, o que agravava ainda mais a situação. ${ }^{141}$ A solução encontrada pelo Presidente da Província foi, mais uma vez, apelar para o "patriotismo" dos deputados. Além disso, recomendou aos futuros administradores uma "conscienciosa", "bem entendida" e "refletida" distribuição das rendas públicas, que levasse em conta as necessidades da Província, conjugada a uma "severa e constante" fiscalização. Tais seriam os "remédios" que restabeleceriam o equilíbrio das contas do governo. ${ }^{142}$

De acordo com o Barão de Parnahyba, o administrador devia atender às reclamações das municipalidades e de outros interessados, tendo em vista, mais que o crédito na lei, a "realidade" dos fundos para as despesas imprescindíveis. O Presidente da Província sugeria, assim, que seria mais prudente dar à administração inteira liberdade para aplicar determinada verba e corrigir possíveis erros na elaboração do orçamento. Este não passava, segundo ele, de mera previsão para a aplicação do resultado da arrecadação. O resultado disso era que nem sempre as administrações podiam atender às demandas de obras porque o valor orçado era insuficiente. $\mathrm{Ou}$, em outros casos, cedendo a pressões, comprometia a realização de outros serviços quando remanejava verbas. Concluindo seu raciocínio, afirmou que se podia ter "muita confiança" nas fontes da riqueza pública da Província, porém lembrando que a principal renda estava sempre sujeita a uma maior ou menor colheita e às oscilações da procura e do preço do principal produto de exportação. Além do mais, como os negócios de exportação não eram realizados em épocas definidas, devido às oscilações do mercado,

\footnotetext{
139 São Paulo Relatorio com que o Exm. Sr. Dr. Francisco Antonio de Souza Queiroz Filho VicePresidente da Provincia de S. Paulo passou a administração ao Vice-Presidente, Exm. Sr. Dr. Elias Antonio Pacheco e Chaves. S. Paulo: Typ. do "Correio Paulistano", 1885. p.29.

${ }^{140}$ São Paulo. Relatorio apresentado a Assembléa Legislativa Provincial de São Paulo pelo Presidente da Provincia João Alfredo Corrêa de Oliveira no dia 15 de fevereiro de 1886. São Paulo: typ. de Jorge Seckler \& C., 1886. p.89 e 94.

${ }^{141}$ São Paulo. Relatorio apresentado a Assembléa Legislativa Provincial de São Paulo pelo Presidente da Provincia Barão do Parnahyba no dia 17 de janeiro de 1887. São Paulo: typ. de Jorge Seckler \& Comp., 1887.p.111.

${ }^{142} \mathrm{O}$ Administrador recomendou ainda "não ser de bom conselho continuar o systema da distribuição de pequenas parcellas para obras publicas, que quase sempre quando em via de realisação, muito excedem aos créditos votados". Ibidem. p. 113.
} 
os administradores não deveriam autorizar despesas para serviços que podiam ser realizados no futuro, em detrimento de outros mais urgentes. ${ }^{143}$

Em novembro de 1887, ao deixar a administração, o Visconde do Parnahyba apresentou novo relatório. ${ }^{144}$ Embora tenha alegado razões de ordem familiar para apresentar pedido de exoneração do cargo, o que motivou sua substituição foi uma série de conflitos envolvendo grupos abolicionistas e a força pública, relatados pelo Chefe de Polícia no seu próprio relatório. Um dos conflitos mais graves ocorreu na própria capital da Província, tendo início em meio a uma festividade na noite do dia 22 de outubro. A prisão de um suposto desordeiro, que segundo o Chefe de Política era um "ébrio habitual" e estava ofendendo o decoro público, fez com que grande número de negros atacasse os policiais. Na noite seguinte, o mesmo grupo teria provocado a força pública, desafiando praças de polícia e promovendo grande desordem no largo do Palácio do Governo, dando "vivas à liberdade e morras aos escravocratas". ${ }^{145}$

Além destes incidentes, vários outros conflitos ocorreram nos últimos meses da administração do Visconde de Parnahyba, envolvendo imigrantes italianos, escravos fugidos, policiais, militares, grupos escravocratas e abolicionistas. De acordo com Maria Helena Machado, ${ }^{146}$ nos inícios de 1887, a derrocada da escravidão como instituição e regime de trabalho se materializava rapidamente. Tratar-se-ia do aprofundamento de uma crise que se fazia sentir desde o princípio da década, caracterizada pela perda do controle sobre a mão-de-obra, e que naquele momento tomava contornos novos com as fugas em massas das fazendas e a desarticulação do trabalho nos eitos.

Toda esta situação elevava os gastos da Administração com a Segurança Pública, pois obrigava o envio de tropas para vários pontos da Província. O Chefe de Polícia afirmou que devido o progresso da Província, com o desenvolvimento das indústrias e as ramificações das estradas de ferros, as vilas e cidades cresciam, fazendo aumentar os gastos com a segurança pública. Nesse sentido, requereu o aumento e

\footnotetext{
${ }^{143}$ Ibidem. p. 114.

144 São Paulo. Exposição com que o Exm. Snr. Visconde do Parnahyba passou a administração da Provincia de São Paulo ao Exm. Snr. Dr. Francisco de Paula Rodrigues Alves, Presidente desta Provincia, no dia 19 de novembro de 1887. São Paulo: Typographia de Jorge Seckler, 1888.

145 São Paulo. Relatorio apresentado ao Illm. E Exm. Snr. Dr. Francisco de P. Rodrigues Alves, Presidente da Provincia de São Paulo, pelo Chefe de Polícia interino, o Juiz de Direito Salvador Antonio Moniz Barreto de Aragão. São Paulo: Typographia a vapor de Jorge Seckler, 1888. p. 6.

${ }^{146}$ MACHADO, Maria Helena. O Plano e o Pânico. Os movimentos sociais na década da abolição. Rio de Janeiro: Editora da UFRJ, São Paulo: Edusp, 1994. p. 227.
} 
aparelhamento da força policial e do corpo de bombeiros. ${ }^{147}$ A chamada polícia local era a que recebia maior número de críticas, pois se tratava de uma corporação constituída de pessoas residentes nos municípios, provavelmente parentes ou amigos de lideranças políticas regionais, que não tinha preparo para o exercício da função. Alguns chefes de polícia argumentavam que a contratação de mais policiais permanentes para substituílos resultaria em economia para os cofres públicos, pois permitiria reduzir o contingente e torná-lo mais efetivo.

Não por acaso, a crise que, segundo Maria Helena Machado, denotava a perda do controle sobre a mão-de-obra coincidiu com um período de crise da cafeicultura. Da mesma forma, ao analisar as finanças provinciais durante sua gestão, o Visconde de Parnahyba afirmou que entre as verbas da despesa a que necessitara de maior importância de crédito suplementar fora a referente ao Serviço da Imigração, para o qual fora estimada uma cota de 443:730\$000, mas gastara-se 992:749\$610. Caso fosse incluída a construção de um novo alojamento para imigrantes na capital da Província, esta importância chegaria a 1.132:214\$661. Isto quando a arrecadação média da Província girava em torno de 4.596:106\$605.

Todavia, o balanço mostrava um equilíbrio entre receitas e despesas naquele exercício. Quanto ao exercício 1888-1889, a expectativa de uma grande safra de café tranqüilizava o Presidente. Ainda assim, o Visconde de Parnahyba criticou a prática adotada pelos deputados provinciais de destinar pequenas cotas do orçamento para obras públicas, as quais geralmente se mostravam insuficientes. Segundo ele, a Assembléia Provincial deveria dar "inteira liberdade" à administração na aplicação de uma quantia em vista dos estudos e orçamentos feitos, pois, sendo os orçamentos "meras previsões", nas condições em que se achavam era mais conveniente que o "legislador previdente" distribuísse a receita com a maior restrição pela despesa

${ }^{147}$ O Chefe de Polícia criticou o uso de militares - a chamada "força de linha" - no serviço de policiamento, afirmando que os mesmos estavam preparados apenas para o "serviço da guarnição". Quanto ao Corpo Policial Permanente, dispunha de 530 praças, nem todos disponíveis para o serviço de policiamento; o Corpo de Urbanos, de 240 guardas; e a chamada Polícia Local, constituída por pessoas residentes nos respectivos municípios, cujo número estaria em torno de 800 praças. São Paulo. Relatorio apresentado ao Illm. E Exm. Snr. Dr. Francisco de P. Rodrigues Alves, Presidente da Provincia de São Paulo, pelo Chefe de Polícia interino, o Juiz de Direito Salvador Antonio Moniz Barreto de Aragão. São Paulo: Typographia a vapor de Jorge Seckler, 1888. p. 25-27. 
indispensável. E isso ocorreria caso o Administrador tivesse liberdade para aplicar os recursos. ${ }^{148}$

A recuperação das finanças provinciais foi confirmada por Francisco de Paula Rodrigues Alves, ${ }^{149}$ apesar da diminuição da arrecadação com as exportações de café, cujo mercado estaria "paralisado". Segundo ele, o exercício de 1888-1889 apresentaria saldo suficiente para o serviço das obras públicas provinciais não contempladas no cálculo da receita e despesa. Os únicos problemas eram os gastos com o serviço de imigração, que dependia de créditos especiais e do recurso de operações de crédito, ${ }^{150} \mathrm{e}$ as fugas em massa de escravos das fazendas, que, ameaçando a desorganização do trabalho agrícola, a ordem pública e a segurança individual exigia recursos para solução de problemas emergenciais. ${ }^{151}$

Pedro Vicente de Azevedo, que assumiu a administração da Província de São Paulo poucos meses antes da queda da Monarquia, afirmou, em um item intitulado "Situação Econômica", que o estado financeiro da Província, se não era "inteiramente próspero" era pelo menos "o mais lisonjeiro possível", tendo em vista os acontecimentos que antecederam a abolição da escravatura. ${ }^{152} \mathrm{De}$ acordo com o Administrador, a previdência dos legisladores desviara, com "suma sabedoria e elevado patriotismo", o golpe que ameaçava o futuro da Província. Ele se referia às medidas em prol da imigração européia, sobretudo as facilidades para que a Administração Provincial contraísse empréstimos necessários, dentro e fora do país, para promover a introdução de trabalhadores europeus. Devido a essas providências ele pudera contrair um empréstimo em Londres, empregando o "escrúpulo" que lhe cumpria como Administrador. ${ }^{153}$

\footnotetext{
${ }^{148}$ São Paulo. Exposição com que o Exm. Snr. Visconde do Parnahyba passou a administração da Provincia de São Paulo ao Exm. Snr. Dr. Francisco de Paula Rodrigues Alves, Presidente desta Provincia, no dia 19 de novembro de 1887. São Paulo: Typographia de Jorge Seckler, 1888. p. 134-137. ${ }^{149}$ São Paulo. Relatorio apresentado á Assembléa Legisltiva Provincial de São Paulo pelo Presidente da Provincia Exm. Snr. Dr. Francisco de Paula Rodrigues Alves, no dia 10 de janeiro de 1888. São Paulo: Typographia a vapor de Jorge Seckler, 1888 .

${ }^{150}$ De acordo com o Presidente, fora necessário realizar empréstimos para pagar dívidas vencidas e cobrir gastos extraordinários com a imigração européia. Ibidem. p. 38-40.

${ }^{151}$ Ibidem. p. 7-8.

${ }^{152}$ São Paulo. Relatorio apresentado á Assembléa Legislativa Provincial de São Paulo pelo Presidente da Provincia Dr. Pedro Vicente de Azevedo no dia 11 de janeiro de 1889. São Paulo: Typograpya a vapor de Jorge Seckler \& C., 1889. p. 150.

${ }^{153}$ Ibidem. p. 151.
} 
Assim, de acordo com Pedro Vicente de Azevedo, a situação financeira da Província era muito animadora e livre de apreensões. Isto devido não apenas os empréstimos contraídos, mas principalmente à elevação do preço do café no mercado internacional, o que permitiria à administração retomar o equilíbrio entre orçamento e despesa, verificado em 1886-1887.

\section{$1.3 \mathrm{O}$ preço da prosperidade}

O título deste capítulo é uma referência a um pequeno livro de Tavares Bastos, publicado em $1861,{ }^{154}$ no qual o então deputado geral, que ficaria conhecido pela defesa de princípios liberais, discutiu alguns problemas do país e como poderiam ser solucionados. Muitas dos problemas que mencionou foram, aliás, apontados por presidentes de província até a queda do regime monárquico, em 1889, cerca de quinze anos após sua morte.

Podemos classificar a maioria dos problemas discutidos por Tavares Bastos em dois grupos. Um deles dizia respeito a assuntos políticos, como a centralização do regime monárquico, as constantes dissoluções e constituições de gabinetes ministeriais, as sucessivas substituições de presidentes de província, a corrupção e escassa representatividade do sistema eleitoral e o atraso, o déficit público e a limitação da instrução pública. O segundo grupo tratava das dificuldades com que lidavam os agricultores: a rotina, a dificuldade de obtenção de imigrantes, os abusos cometidos nos contratos de parceria e a supressão tardia, mas repentina, do tráfico negreiro.

Todos estes problemas tinham, segundo ele, uma origem única e remota: o absolutismo predominante na metrópole portuguesa, quando do início da colonização da América Portuguesa. Para Tavares Bastos, sem ter uma visão clara do processo histórico, muitos se iludiam ao associar os males do país ao governo pessoal do monarca, mas este nunca excedia os limites de seus poderes constitucionais. O verdadeiro problema estaria na ausência de um desenvolvimento gradual do espírito

\footnotetext{
${ }^{154} \mathrm{O}$ alagoano Tavares Bastos publicou o livro Os Males do Presente e as Esperanças do Futuro com o pseudônimo "Um excêntrico". A edição que consultamos reúne, sob o mesmo título, outros trabalhos do autor, entre eles uma "Memória sobre a Imigração", que apareceu como anexo ao Relatorio da Sociedade Internacional de Imigração em 1867. BASTOS, Aureliano Cândido Tavares. Os Males do Presente e as Esperanças do Futuro (Estudos Brasileiros). $2^{\mathrm{a}}$ ed. São Paulo: Ed. Nacional; Brasília: Instituto Nacional do Livro, 1976.
} 
público, da prática do self-governement. Somente um governo sábio e forte poderia erradicar os males do país, um governo forte, porém democrata, expressão da vontade popular de se auto-governar, tal como existiria na Inglaterra e nos Estados Unidos.

Conforme assinalamos, os presidentes que governaram o Pará e São Paulo, entre 1868 e 1889, apresentaram, em seus relatórios e falas, diagnósticos dos problemas das províncias que administravam e propostas para superá-los. Isto não significa, porém, que os problemas encontrados e as soluções propostas fossem idênticos. Mas muitos deles se mostraram particularmente preocupados com o equilíbrio entre receita e despesa, o que os levava a acompanhar de perto o desempenho das atividades extrativistas, no caso do Pará, e da cafeicultura, no caso de São Paulo. Todavia, se estas economias exportadoras eram as principais responsáveis pela arrecadação das rendas públicas, despertava, por outro lado, a preocupação dos presidentes da província em relação ao futuro. A concepção geral era de que cabia à Administração Provincial não apenas sanar os males do presente, mas também alimentar a esperança no futuro.

Nesse sentido, os administradores preconizavam o uso racional dos recursos públicos e o equilíbrio entre as atividades econômicas principais, na tentativa de evitar a dependência em relação a uma única fonte de receita. Fazia parte desta política o apelo ao patriotismo dos deputados provinciais, de quem dependia a definição do orçamento e a quem os presidentes eram obrigados a prestar contas da sua administração. Entretanto, ao contrário do que possa parecer, esta situação não tornava os legisladores provinciais senhores da situação, pois suas atribuições eram limitadas. ${ }^{155}$ Por outro lado, como o Governo Imperial vencia praticamente todas as eleições os políticos que ocupavam postos nas esferas municipal, provincial e geral pertencia ao mesmo partido político. Isso diminuía em muito as divergências, mas não descartava a necessidade de alianças políticas. $^{156}$

\footnotetext{
${ }^{155}$ O Ato Adicional de 1834 transformou os Conselhos Gerais de Província em Assembléias Provinciais, cujas atribuições eram mais amplas. Além disso, os deputados provinciais passaram a ser escolhidos pelos eleitores das províncias, o que, apesar das restrições ao direito de voto, ampliava a participação das elites das províncias no sistema político imperial. Mas a autonomia as Assembléias Provinciais era limitada, pois muitos assuntos relativos às províncias dependiam da decisão da Câmara dos Deputados.

${ }^{156}$ Entre as limitações das Assembléias Provinciais estava a de não poder criar impostos nas suas jurisdições. Na década de 1870, as Assembléias Provinciais de São Paulo, Rio de Janeiro e Minas Gerais tentaram proibir, ou pelo menos dificultar muito, a introdução de escravos nestas províncias por meio de impostos. Como não tinham essa atribuição, os deputados provinciais obrigaram os compradores a matricular os escravos que importassem de outras províncias, e a pagar, no ato da matrícula, uma taxa elevada.
} 
A análise das falas e relatórios dos presidentes de província indica que a agricultura era tida como sinônimo de progresso e a civilização. Desejada no Pará, estabelecida em São Paulo, para ela se destinava boa parte dos recursos públicos. Quando cuidavam da abertura e manutenção de estradas, da fundação de escolas e do incentivo à imigração e colonização, era na agricultura que pensavam legisladores e administradores provinciais. E, em se tratando das necessidades dos fazendeiros, os políticos elegiam como o principal deles o suprimento de mão-de-obra. A escassez de capitais, por vezes apontada como um problema também crucial, foi sendo deixado de lado à medida que a abolição da escravatura se tornava iminente. Encontrar uma fonte estável de suprimento de mão-de-obra era o objetivo da maioria dos governantes. As alternativas que se colocavam não eram muitas: índios, brasileiros, europeus e asiáticos. Nessa lista só não estavam incluídos os escravos em vias de conquistar a liberdade. A expectativa geral era de que o ex-escravo não se submeteria ao trabalho que fizera quando cativo.

O que procuramos assinalar foi que os presidentes de província desempenhavam uma função fundamental no sistema político imperial. Cabia a eles negociar com as elites provinciais para que a política do gabinete ministerial ao qual serviam pudesse ser executada sem maiores dificuldades no âmbito provincial. Várias necessidades locais entravam nesta negociação, mas um nos parece ter sido o mais comum e importante, sobretudo no período estudado: a criação de uma força de trabalho numerosa, disciplinada e dependente. Tratava-se de uma necessidade comum tanto às elites envolvidas com os negócios da borracha como às elites envolvidas na produção agrícola.

Nossa análise corrobora, portanto, conclusões como a de Miriam Dolhnikoff, ${ }^{157}$ qual seja a de que as elites regionais, a despeito de suas especificidades, não estavam submetidas a uma elite diferenciada, proveniente das regiões cafeeiras ou açucareiras, isto é, uma elite dirigente nacional, com um projeto político próprio, que se impunha aos demais grupos. Ao longo do período imperial foi sendo construído um arranjo político no qual a sustentação de qualquer grupo nos principais postos do sistema monárquico dependia do estabelecimento de alianças com grupos regionais. Estes, por meio de suas demandas, se faziam representar na organização institucional do Império.

${ }^{157}$ DOLNIKOFF, Miriam. Elites regionais e a construção do Estado Nacional. Op. cit.; DOLNIKOFF, Miriam. O Pacto Imperial. Op. cit. 
Alguns procedimentos dos presidentes de província, analisados neste capítulo, exemplificam esta tese. Os insistentes esforços dos administradores do Pará no sentido de beneficiar a agricultura, transferindo recursos do setor extrativista, são indícios claros de uma aliança política entre setores que viam na exploração agrícola uma alternativa mais viável de desenvolvimento para o país. Isso não significa, contudo, que eles ignorassem demandas do setor extrativista, pois, como veremos no próximo capítulo, o "Serviço de Catequese e Civilização dos Índios" era orientado de forma a disponibilizar essa mão-de-obra - a mais requerida nos trabalhos de coleta dos produtos da floresta para tal setor.

Em São Paulo, Sebastião José Pereira argumentava que a iniciativa privada devia ser controlada pelo Governo, a fim de que o progresso e o entusiasmo ali verificado não gerassem uma crise. Assim, se nos momentos de crise o Governo se fazia necessário para auxiliar as províncias a encontrar soluções para seus problemas, nos momentos de prosperidade era igualmente indispensável, mas para garantir a organicidade do progresso. O desenvolvimento regional tinha, portanto, o seu preço: o controle e a fiscalização do Governo Imperial.

Em suma, a tese que aqui sustentamos é de que a criação de uma força de trabalho numerosa, disciplina e dependente, que exigia a reorganização do mercado de trabalho em novas bases, dada principalmente a expectativa da abolição da escravatura, transformou-se numa espécie de moeda de troca, utilizada pelos grupos governantes para conseguir o apoio das elites regionais ao seu plano político. Isto não significa que o problema estivesse resolvido. Os grupos que se alternavam no poder tinham planos políticos específicos, que nem sempre se harmonizavam com os daqueles que controlavam o Governo Imperial, e as alternativas de suprimento de mão-de-obra eram várias e dependiam de uma série de medidas para que se tornassem efetivas. As últimas décadas do regime monárquico foram marcadas pelas tentativas dos políticos de encontrar um equilíbrio entre as demandas de cada setor. Nos próximos capítulos discutiremos mais detidamente as principais alternativas de suprimento de braços e como podiam se conformar a projetos políticos em jogo. 


\section{CAPÍTULO II SOLUÇÕES IMPROVÁVEIS}

\subsection{A escravidão dissimulada}

Entre as várias alternativas de suprimento de mão-de-obra para as lavouras brasileiras estava a introdução de trabalhadores asiáticos e, entre eles, os chamados coolies. ${ }^{1}$ O contrato que o Barão de Mauá firmou com o governo brasileiro na década de 1850, estabelecia que a Companhia de Comércio e Navegação do Amazonas deveria criar e manter, num prazo de dez anos, doze colônias de imigrantes na região em que a empresa iria operar. Porém, uma tentativa inicial de estabelecer 1091 colonos, sendo trinta chineses e o restante portugueses, revelou-se um fracasso, levando Irineu Evangelista de Sousa a afirmar que a ocupação da região deveria ser feita pelo aproveitamento da mão-de-obra indígena, "mais talhada para aquela missão por índole e por natureza". ${ }^{2}$

Depois disso, pouco se discutiu a introdução de imigrantes asiáticos no Pará. ${ }^{3}$ $\mathrm{Na}$ verdade, as possibilidades de utilização da mão-de-obra de estrangeiros na região eram consideradas tão remotas que sua procedência não suscitava grandes polêmicas. Já nas áreas cafeeiras mais experiências com imigrantes asiáticos e o debate, em alguns

\footnotetext{
${ }^{1}$ Nas fontes que pesquisamos o termo é utilizado sem tradução - razão pela qual mantivemos a ortografia - e geralmente como sinônimo de chineses. Na verdade, eram trabalhadores de várias regiões do oriente, que emigravam temporariamente para a América e, dizia-se, sujeitavam-se a baixos salários e condições precárias de trabalho e de vida. Por estas e por outras razões, a utilização de sua força de trabalho era considerada por seus críticos como uma escravidão dissimulada.

${ }^{2}$ EL-KAREH, Almir Chaiban. A Companhia de Comércio e Navegação do Amazonas e a Defesa da Amazônia Brasileira: o imaginado grande banquete comercial. V Congresso Brasileiro de História e $6^{\mathbf{a}}$ Conferência Internacional de História de Empresas. ABPHE. Caxambú, MG, 7 a 10 de setembro 2003. [Citado 15 novembro 2005]. Disponível na World Wide Web: <www.abphe.org.br/congresso2003/Textos/Abphe_2003_74.pdf>.

${ }^{3}$ É possível que tenham sido utilizados coolies nos trabalhos da Estrada de Ferro Madeira-Mamoré, mas não há indicações mais precisas para o período aqui estudado. De acordo com Manoel Rodrigues Ferreira e Francisco Foot Hardman, foram recrutados trabalhadores de várias nacionalidades, como portugueses, irlandeses, italianos, bolivianos e norte-americanos, além de brasileiros, principalmente cearenses. Isto no século XIX, pois entre 1907 e 1912 vieram trabalhadores de todas as partes do mundo. Para o nosso interesse aqui, cumpre-nos ressaltar que a construção da ferrovia não gerou um debate sobre a mão-deobra na imprensa de Belém ou nos relatórios dos presidentes que administraram o Pará. FERREIRA, Manoel Rodrigues. A Ferrovia do Diabo. História de uma estrada de ferro na Amazônia. São Paulo: Melhoramentos, 1981. p. 209-212; HARDMAN, Francisco Foot. Trem Fantasma. A modernidade na selava. $1^{a}$. reimp. São Paulo: Companhia das Letras, 1988. p. 130-142.
} 
momentos, foi intenso. As primeiras tentativas, segundo Jeffrey Lesser, ocorreram a partir de 1810, mas três anos antes, diante das pressões britânicas contra o tráfico negreiro, já se propunha a contratação de trabalhadores da China e da Índia. ${ }^{4}$ Algumas centenas de plantadores de chá chineses foram, então, empregados na fazenda do Governo Imperial, no Rio de Janeiro e na fazenda imperial de Santa Cruz, em Niterói, aos quais outro grupo, constituído por cerca de quatrocentos ou quinhentos imigrantes da mesma nacionalidade viria se juntar em 1812. Mas o cultivo do chá fracassou por vários motivos: os chineses não teriam conseguido trazer suas mulheres e eram tratados de forma severa, alimentando um mito do Oriente de que a América do Sul continha "os Estados das Bestas", habitados por povos bárbaros. Todavia, por volta de 1835, ainda haveria cerca de trezentos trabalhadores chineses naqueles locais.

É provável que o fracasso dessa experiência tenha levado as elites imperiais a recusar a oferta de Lord Aberdeen, em 1843, para negociar a importação de sessenta mil chineses. Mas a supressão do Tráfico Negreiro e a repercussão da participação dos chineses na expansão da economia do Peru e Cuba fizeram com que o governo brasileiro reconsiderasse a decisão anterior. Uma delegação enviada a Londres negociou a vinda de seis mil trabalhadores asiáticos, em cujos contratos, segundo Jeffrey Lesser, sobressaíam vários preconceitos, como o de que todos os chineses eram viciados em ópio e o de que os trabalhadores provenientes das regiões produtoras de chá não sabiam lidar com outros tipos de cultura, argumento utilizado para preteri-los. Além disso, havia a imposição de que os trabalhadores fossem casados ou comprometidos, tendo o direito de trazer noivas, mulheres e filhos menores de doze anos.

Apesar de terem sido introduzidos poucos trabalhadores asiáticos naquela oportunidade, a importação reacendeu o debate. De acordo com Emilia Viotti da Costa, ${ }^{5}$ as opiniões estavam divididas: alguns consideravam o chinês a salvação da lavoura cafeeira, mas outros afirmavam se tratar de uma perspectiva abominável devido ao seu suposto atraso intelectual e desinteresse pelo trabalho. Em uma memória enviada ao governo, intitulada "A imigração chinesa e o que [se] sabe sobre seus resultados em vários países", 6 Sérgio F. de Macedo assinalou que o chinês não era como o negro, que

\footnotetext{
${ }^{4}$ LESSER, Jeffrey. A Negociação da Identidade Nacional. Imigrantes, minorias e a luta pela etnicidade no Brasil. Trad. Patrícia de Queiroz C. Zimbres. São Paulo: Editora da UNESP, 2001. p. 40

${ }^{5}$ COSTA, Emília Viotti da. Da Senzala à Colônia, Op. cit., p. 168-171.

${ }^{6}$ LESSER, Jeffrey. Op. cit. p. 41-43.
} 
segundo ele só trabalhava por algum tempo para ganhar o sustento, nem se estabelecia, ou seja, não colonizava. Em contrapartida, outros diziam que eles não viriam aumentar os conhecimentos agrícolas do país, nem melhorar a moralidade e a civilização, que nada impediria a miscigenação deles com os negros e que não se dedicavam ao trabalho porque não eram cristãos.

O debate continuou acirrado. De um lado, Luiz Peixoto de Lacerda Werneck, um fazendeiro de café diplomado em Direito pela Academia de Paris e pela Universidade de Roma, afirmava que nenhum trabalhador imigrante substituiria o escravo e que os chineses eram "homens-animais" egoístas e orgulhosos, dados ao abandono dos filhos. Além disso, que a "raça brasileira" ainda em formação e já prejudicada pela "disformidade do índio e do africano", seria ainda mais degenerada com a introdução de chineses. De outro lado, Quintino Bocaiúva e outros argumentavam que os asiáticos contribuiriam para atenuar a crise brasileira de mão-deobra e para facilitar a adoção do regime de pequena propriedade, pois não teriam dificuldades em se adaptar ao clima do país, eram dóceis, sóbrios e dispostos a trabalhar por baixos salários. A estas características geralmente acrescentavam o fato de que eles não se estabeleceriam definitivamente no país, o que deixava transparecer, mesmo entre os adeptos da proposta, o preconceito em relação aos asiáticos. ${ }^{7}$

Por volta de 1870, Diogo Velho, Ministro da Agricultura, comércio e obras públicas, e alguns membros da Sociedade Auxiliadora da Indústria Nacional passaram a fazer intensa campanha pela introdução de coolies no país. ${ }^{8}$ Houve protestos em nome "da medicina e da raça”, mas a Sociedade deu parecer favorável à proposta com o argumento de que se tratavam de "elementos de trabalho", e não de colonos propriamente ditos. Todavia, pressões internacionais frustram as intenções do governo brasileiro de promover a contratação de coolies. Em 1873, a China proibiu toda a emigração, com exceção da voluntária, e a Inglaterra passou a admitir a saída de trabalhadores dos portos de Hong Kong apenas para suas colônias. ${ }^{9}$

Apesar disso, a possibilidade de introdução de imigrantes asiáticos no país voltou a ser debatida, ainda com mais intensidade, a partir da realização do Congresso

\footnotetext{
${ }^{7}$ Ibidem. p. 44-48.

${ }^{8}$ CARNEIRO, José Fernando. Fazendeiros na História do Brasil. Província de São Pedro, Porto Alegre, 11 (21):32-52, dez. 1957. p. 41-42.

${ }^{9}$ LESSER, Jeffrey. Op. cit. p. 50.
} 
Agrícola de 1878, convocado pelo Ministro da Agricultura, João Lins Vieira Cansansão de Sinimbu, que três anos antes tentara estabelecer uma diferença entre chineses e coolies. Estes últimos seriam provenientes das cidades e arredores urbanos, preguiçosos, viciados e sem força muscular; já os chineses habitariam a parte montanhosa do país e seriam elementos capazes e convenientes para o Brasil. ${ }^{10}$

Durante o Congresso Agrícola e enquanto esteve na presidência do Conselho de Ministros, Sinimbu transformou a imigração asiática em principal proposta do governo liberal para ampliar a oferta de braços no país, particularmente nas áreas cafeeiras. A questão passou, então, para o âmbito das disputas político-partidárias, uma vez que os republicanos se sobressaíram na crítica a tal alternativa de suprimento de braços para as lavouras. Esta divisão se fez presente na comissão enviada pelo Clube da Lavoura de Campinas, principal associação de cafeicultores da Província de São Paulo, durante o evento. Após seu término, ela continuou por alguns anos no Parlamento, na Assembléia Provincial de São Paulo e nas páginas dos jornais ligados ao Partido Liberal e Partido Republicano.

De acordo com uma notícia publicada na Gazeta de Campinas, no dia 21 de junho de 1878, uma assembléia geral dos sócios do Clube da Lavoura encarregou uma comissão para apresentar sugestões sobre o tema do evento e representar a associação durante o mesmo. Esta comissão, constituída por seis pessoas, sendo duas de cada um dos partidos políticos existentes, ${ }^{11}$ entrou em atrito antes mesmo de embarcar para o Rio de Janeiro. No dia 4 de julho, o Barão de Atibaia publicou um comunicado na imprensa de Campinas, afirmando que havia se desligado da comissão e que compareceria ao evento como "simples lavrador do município", por ter discordado de alguns "pontos vitais" que a comissão decidira apresentar como medida urgente para solucionar problemas dos fazendeiros. ${ }^{12}$ Dias depois, outro integrante da comissão, o Barão de

${ }^{10}$ CARNEIRO, José Fernando Op. cit., p. 41. Segundo Jeffrey Lesser, em 1875, Sinimbu convenceu o Ministro da Agricultura, Coelho de Almeida, a solicitar a um membro da Sociedade Auxiliadora da Indústria Nacional e da delegação brasileira à Exposição Internacional da Filadélfia que examinasse o papel da imigração nos Estados Unidos. Contrariamente ao seus propósitos, o observador não aconselhou a introdução de coolies no Brasil. LESSER, Jeffrey. Op. cit. p. 51.

${ }^{11}$ CONGRESSO Agricola. Gazeta de Campinas, 22/06/1878, "Noticiario".

${ }^{12}$ A comissão era formada, inicialmente, por Jorge Miranda e Campos Salles, do Partido Republicano; conselheiro Albino José Barbosa de Oliveira e Barão de Atibaia, do Partido Conservador; Barão de Indaiatuba e João de Ataliba Nogueira, do Partido Liberal. BARÃO DE ATIBAIA. Congresso Agricola. Gazeta de Campinas, 04/07/1878, "Secção Particular". Apesar deste comunicado, na lista de presenças do Congresso Agrícola, o Barão figura como representante do Clube da Lavoura de Campinas; ver: Congresso Agricola. Coleção de Documentos. Op. cit. p.4. 
Indaiatuba, afirmou que não podia deixar a cidade, provavelmente devido a uma greve de colonos em suas fazendas. ${ }^{13} \mathrm{O}$ republicano Jorge Miranda, que era advogado do Barão de Indaiatuba na questão com os colonos, também se desligou da comissão, mas sem apresentar justificativa. ${ }^{14}$

Apesar disso, o documento elaborado pela comissão acabou sendo acolhido por um número expressivo de fazendeiros paulistas e de representantes seus que estavam presentes no Congresso Agrícola. Isto se deu durante uma reunião realizada na noite de abertura dos trabalhos, na residência do conselheiro Albino José Barbosa de Oliveira. ${ }^{15}$ Formou-se, então, uma nova comissão, presidida pelo conselheiro e tendo como secretários Campos Salles e Antonio Moreira de Barros. Assim como a comissão anterior, esta também evidenciava uma preocupação com o equilíbrio políticopartidário, pois os três partidos políticos estavam representados na mesma proporção.

Mas as divergências começaram logo na reunião em que se decidiu adotar as propostas do Clube, proporcionadas pelo próprio anfitrião e presidente da comissão, que somente concordou em subscrever o documento com a condição de que ficasse consignada a sua restrição ao item que sugeria a instituição do casamento civil. Alegando que o texto propunha a medida em caráter obrigatório, e não facultativo, como entendiam alguns, o conselheiro Albino José Barbosa de Oliveira, juntamente com integrantes de uma facção do Partido Conservador conhecida como "ultramontana", ${ }^{16}$ aproveitou esta suposta ambigüidade do documento para fazer propaganda política. $^{17}$

\footnotetext{
${ }^{13} \mathrm{O}$ nome do Barão de Indaiatuba aparece na lista de pessoas que justificaram o seu não comparecimento ao Congresso. Os anais do evento não fornecem as razões alegadas, entretanto, como apenas dois dias antes do início do Congresso os jornais informavam que o Chefe de Polícia estava inspecionado as colônias do Barão com o intuito de "conter e apaziguar" os grevistas, tudo indica que fosse esse o motivo da ausência. Ver: Congresso Agricola. Coleção de Documentos. Op. cit. p.15; AMPARO. Gazeta de Campinas, 06/07/1878, "Noticiario".

${ }^{14}$ BARÃO DE INDAIATUBA et all. Club da Lavoura. Gazeta de Campinas, 23/06/1878, "Secção Particular".

${ }^{15}$ REUNIÃ் dos lavradores da Provincia de S. Paulo. Gazeta de Campinas, 12/07/1878, Editorial.

16 "Ultramontanos" é um termo que teria surgido na França para designar aqueles que preconizavam a supremacia papal nos assuntos da Igreja Católica, em detrimento da interferência do poder temporal. No Brasil, com grande carga pejorativa, ele foi utilizado pelos liberais para designar os grupos católicos contrários ao processo de laicização da sociedade, através da instituição do casamento e do registro civis, da secularização dos cemitérios, entre outras medidas que culminariam na separação entre o Estado e a Igreja Católica. Entre os "ultramontanos" que realizaram discursos criticando a proposta da instituição do casamento civil estava o vigário José Joaquim de Sousa Oliveira, residente em Campinas. Ver: Congresso Agrícola. Coleção de Documentos. Op. cit., p. 173-174. Sobre o "ultramontanismo", ver: MARTINS, Karla Denise. Cristóforo e a Romanização do Inferno Verde: as propostas de D. Macedo Costa para a
} 
A instituição do casamento civil, do registro civil, a liberdade de cultos e a secularização dos cemitérios públicos, que também faziam parte das propostas apresentadas, eram medidas que os imigrantistas defendiam como sendo necessárias para atrair trabalhadores dos países cuja maioria da população não era católica. Entretanto, caso elas fossem adotadas teriam como consequiência a separação entre o Estado e a Igreja, com a qual os conservadores "ultramontanos" não concordavam. Além disso, o documento que seria apresentado em nome dos fazendeiros paulistas propunha o incentivo à imigração européia, enquanto os "ultramontanos" tendiam a apoiar a utilização do braço livre nacional, por serem contrários à introdução no país de trabalhadores protestantes.

Durante o Congresso Agrícola, Campos Salles e Moreira de Barros, políticos ligados ao Partido Republicano e ao Partido Liberal, respectivamente, também entraram em atrito. A divergência estava relacionada com a proibição aos "locadores" de serviços de votar nas eleições, proposta com a qual Campos Salles teria concordado inicialmente. ${ }^{18}$ Segundo ele, os participantes da reunião haviam decidido apresentar as sugestões formuladas pelos representantes do Clube da Lavoura, acrescidas de outras três: a transferência dos núcleos coloniais do Governo para as proximidades dos centros produtores, a fundação de escolas agrícolas e a proibição aos "locadores" de serviços de votarem nas eleições.

Campos Salles argumentou que esta proposta contrariava o direito mais importante do cidadão, mas que fizera um acordo com Antonio Moreira de Barros para assinar o documento sem fazer qualquer restrição, adotando tal sugestão apenas sob o ponto de vista econômico, ou seja, como medida complementar daquelas destinadas a incentivar a substituição do trabalho escravo pelo trabalho livre. Sem explicar os

Civilização da Amazônia (1860-1890). Tese (Doutorado em História), Departamento de História, UNICAMP, 2005.

${ }^{17}$ O Partido Liberal e o Partido Republicano eram favoráveis à instituição do casamento civil, do registro civil, da secularização dos cemitérios, da liberdade de cultos e da separação entre o Estado e a Igreja. BRASILIENSE, Américo. Os Programas dos partidos e o Segundo Império. Rio de Janeiro, Fund. Casa de Rui Barbosa/ Brasília, Senado Federal, 1979. p. 58.

${ }^{18}$ Durante a reunião realizada na residência do conselheiro Albino ficou decidido que as propostas do Clube da Lavoura de Campinas seriam adotadas, acrescentando-se outras três: a transferência dos núcleos coloniais do Governo para as proximidades dos centros produtores, a fundação de escolas agrícolas e a privação do direito de voto aos "locadores" de serviço. Os termos locador e locatário eram empregados no século XIX em sentido contrário aos do que se utilizam atualmente, razão pela qual optamos por manter a expressão original entre aspas. O discurso de Campos Salles encontra-se em Congresso Agrícola. Coleção de Documentos. Op. cit., p. 166-167. 
motivos, Campos Salles declarou que havia reconsiderado sua decisão e que não mais abriria mão de seus princípios políticos. Posteriormente, Campos Salles e Antonio Moreira de Barros divergiram novamente, quando este último afirmou, durante seu discurso no Congresso Agrícola, que o parecer da comissão a que ambos pertenciam aconselhava a introdução de trabalhadores chineses no país como "meio de transição", para realizar a substituição do trabalho escravo pelo livre. ${ }^{19}$

Ao se pronunciar desta forma, Antonio Moreira de Barros foi interrompido por diversos apartes, um dos quais de autoria de Campos Salles, que afirmou não ser aquela a opinião da maioria dos membros da comissão, pois ela condenava os asiáticos como "elemento de população", admitindo-os somente como "meio de transição para o trabalho livre". ${ }^{20}$ Por fim, acrescentou que a comissão condenara "sobretudo" a "introdução oficial" de trabalhadores asiáticos. ${ }^{21}$

A intervenção de Campos Salles tinha, à primeira vista, o intuito de ressaltar as restrições que o parecer da comissão fazia em relação aos trabalhadores asiáticos e que haviam sido deliberadamente omitidas por Antonio Moreira de Barros. Ele certamente sabia que este último assim procedia não porque censurava os preconceitos que o aludido documento alimentava a respeito dos asiáticos, mas por fazer a política do Gabinete com o qual estava comprometido. ${ }^{22}$ Sob este ponto de vista, e considerando também que o aludido parecer nada mencionava em relação à "introdução oficial" de braços asiáticos no país, é muito provável que o objetivo de Campos Salles fosse atacar uma das principais propostas que o Presidente do Conselho de Ministros procurava implementar para conquistar o apoio dos fazendeiros de café.

Desde que havia assumido o cargo, em 5 de janeiro de 1878, após dez anos de domínio do Partido Conservador e com a incumbência, que lhe fora atribuída pelo Imperador, de realizar a reforma da eleição direta, João Lins Vieira Cansansão de Sinimbu vinha dando repetidas declarações de que não pretendia aprovar novas medidas em relação à emancipação da escravatura. ${ }^{23}$ Esta decisão, por sinal, foi bastante elogiada

\footnotetext{
${ }^{19}$ Ibidem. p. $185-190$.

${ }^{20}$ Ibidem. p. 185.

${ }^{21}$ Ibidem. p. 189.

${ }^{22}$ Antonio Moreira de Barros era um dos principais líderes do Partido Liberal em São Paulo e ocuparia, em 1879, o Ministério dos Estrangeiros do Gabinete Sinimbu.

${ }^{23}$ No dia 4 de abril de 1879, por exemplo, o Correio Paulistano noticiou que o Presidente do Conselho havia feito uma declaração à Câmara dos Deputados olhando para a questão "com os mesmos sentimentos humanitários dos que a consideram pelos princípios da civilização", mas atendendo sobretudo para as
} 
durante o Congresso Agrícola, principalmente por parte de políticos filiados ao Partido Liberal como Rodrigo Lobato Marcondes Machado, que, assim como Antonio Moreira de Barros, residia em Taubaté e apoiava a proposta de se introduzir trabalhadores asiáticos nas lavouras como forma de transição para o regime de trabalho livre. ${ }^{24}$

Mas isto não era suficiente para que o Ministro conseguisse obter dos senhores de terras e de escravos o apoio necessário para a realização do seu programa de governo. Para tanto, ele precisava satisfazer as necessidades que eles reputavam como sendo as mais urgentes da lavoura: a aquisição de braços e de capitais. Seria, portanto, esta a finalidade do Congresso Agrícola: consultar diretamente os proprietários rurais a respeito destes temas e, tomando suas sugestões como referência, orientar a ação do Governo nesse setor a fim de que ele se fortalecesse para a batalha da reforma eleitoral.

Entretanto, o próprio discurso que Sinimbu realizou na sessão de abertura dos trabalhos do Congresso contraria as suposições de que se tratava de uma iniciativa meramente consultiva. ${ }^{25}$ Em primeiro lugar, porque ele atrelou a solução da questão de capitais à de braços, afirmando que a criação de instituições de crédito encontrava séria objeção no fato de que o valor da propriedade rural dependia basicamente do número de braços, isto é de escravos, que a cultivava. Sobre uma base tão instável, perguntou ele, que estabelecimentos sólidos poderiam ser fundados $?^{26}$ Uma vez definido o tema prioritário, Sinimbu passou a desencorajar a idéia da imigração européia, afirmando que se tratava de uma mão-de-obra cara e que não era recomendada para o trabalho assalariado, pois tinha "propensões naturais" a se tornar proprietária, razão pela qual se sujeitava ao sistema de parceria apenas por tempo limitado, como mera transição. A alternativa mais viável seria então, segundo ele, a importação de coolies ou chineses, que teriam sido utilizados com sucesso pelas colônias inglesas, francesas e espanholas, bem como em vários pontos das Antilhas, da América Latina e dos Estados Unidos, quando haviam passado pela crise da emancipação da escravatura.

Sinimbu transformou a proposta de imigração asiática numa questão de política nacional e, embora suas convicções sobre o assunto provavelmente já

condições em que se achava o país e a "indústria agrícola", não haveria de ser com seu voto, nem com o seu conselho que se faria mais do que estava feito pela Lei de 28 de Setembro de 1871. Ver: EMANCIPAÇÃO do elemento servil. Correio Paulistano, 04/04/1879, "Noticiario Geral".

${ }^{24}$ Congresso Agrícola. Coleção de Documentos. Op. cit., p. 196.

${ }^{25}$ Ibidem. p. 125-129.

${ }^{26}$ Ibidem. p. 128. 
estivessem firmada há muito tempo, foi a partir do Congresso Agrícola que começou a colocá-la em prática. ${ }^{27}$ Além de introduzir o assunto no discurso de abertura do evento, Sinimbu cuidou ainda para que, no encerramento das sessões, A. Scott Blacklaw, representante do The New London \& Brasilian Bank na cidade de Rio Claro, fizesse uma conferência expondo os conhecimentos que adquirira ao observar o trabalho dos coolies no Ceilão e outras regiões. ${ }^{28}$ Era como se, abrindo e encerrando o Congresso com opiniões favoráveis à importação de trabalhadores asiáticos, o Presidente do Conselho de Ministros quisesse compensar toda a carga de preconceitos que existia em relação aos mesmos, ainda que para tanto fosse necessário alimentar aqueles que existiam a respeito dos próprios trabalhadores brasileiros, os quais, na opinião dele, não se prestavam a qualquer serviço "contínuo e aturado".

Esta estratégia parece não ter escapado aos redatores dos principais periódicos vinculados ao Partido Republicano de São Paulo. Isto porque, apenas uma semana depois do término do Congresso, a Gazeta de Campinas, publicou uma notícia na qual o redator, referindo-se a um editorial que o jornal havia publicado condenando a importação de coolies, afirmou que o jornal A Província de São Paulo também se manifestara no mesmo sentido. Após lembrar que durante o Congresso Agrícola a "desastrada idéia" havia sido tristemente lembrada, o redator afirmou que um jornal dos Estados Unidos, referindo-se ao emprego de trabalhadores asiáticos naquele país, considerou-os como uma "terrível praga". ${ }^{29}$

$\mathrm{O}$ artigo ao qual se referiu o articulista do jornal A Província de S. Paulo, publicado no periódico dos Estados Unidos, nem chegou a ser transcrito pelo redator da Gazeta de Campinas. Isto demonstra que sua intenção não era propriamente apresentar aos leitores argumentos contra a introdução de trabalhadores asiáticos no país, mas ressaltar que os dois principais jornais vinculados ao Partido Republicano de São Paulo tinham o mesmo ponto de vista a respeito desta questão.

\footnotetext{
${ }^{27}$ LESSER, Jeffrey. Op. cit. p. 51 e 56. Ao se tornar Presidente do Conselho de Ministros, Sinimbu encarregou o Cônsul-Geral nos Estados Unidos, Salvador de Mendonça, que era um dos adeptos da imigração asiática, de preparar um relatório sobre o assunto, que seria publicado na forma de livro em 1879, ou seja, após o Congresso Agrícola.

${ }^{28}$ Ver: "Conferencia feita pelo Sr. Blacklaw perante o Congresso Agricola, em 12 de julho de 1878, ácerca do trabalho dos coolies". In: Congresso Agrícola. Coleção de Documentos. Op. cit., p. 255-262.

${ }^{29}$ De acordo com o redator, o periódico publicado nos Estados Unidos era Correspondência dos Estados Unidos, editado em Nova Iorque, mas dirigido aos brasileiros. Ver: OS COOLIES. Gazeta de Campinas, 19/07/1878, "Noticiario".
} 
A preocupação dos periódicos republicanos em dar uma resposta imediata às articulações de Sinimbu pode parecer uma conseqüência natural das divergências ocorridas entre Campos Salles e Moreira de Barros, durante o Congresso Agrícola. Todavia, como a principal incumbência que o Imperador havia dado ao novo Ministério era a da reforma eleitoral, somente em meados de 1879 é que Sinimbu conseguiria pôr em prática seu plano para importar trabalhadores asiáticos. ${ }^{30}$ Enquanto isso, coube principalmente aos jornais ligados ao Partido Liberal não deixar esquecer esta alternativa de suprimento de mão-de-obra para as lavouras, recomendando o trabalho dos coolies e chineses através da publicação de testemunhos de viajantes e de estudos técnicos a respeito dos principais hábitos daqueles povos e sobre a produtividade do seu trabalho. ${ }^{31}$ Assim, artigos como o que foi mencionado pelo redator da Gazeta, na notícia supracitada, eram publicados principalmente pelos órgãos republicanos a fim de polemizar com os periódicos liberais e apresentar seus argumentos contrários à introdução de trabalhadores asiáticos nas lavouras do país. ${ }^{32}$

Durante o Congresso Agrícola de $1878,{ }^{33}$ comissões nomeadas para representar cafeicultores manifestaram-se favoravelmente à introdução de asiáticos no país, embora não fossem poucos os que se declarassem contrários a esta alternativa de suprimento de braços para as lavouras. No ano seguinte, dois grupos, um favorável à introdução de asiáticos e outro contrário, digladiaram-se na Assembléia Legislativa Provincial de São Paulo em face de um projeto de lei apresentado em 1879, que

\footnotetext{
${ }^{30}$ Sinimbu enviou uma "missão naval" e uma "missão de tratado" à China, encarregadas de estabelecer relações diplomáticas e negociar a contratação de trabalhadores chineses, além de uma missão diplomática a Londres para discutir questões trabalhistas com diplomatas chineses. Estas iniciativas provocaram uma enérgica reação da Câmara dos Deputados, comandada por Joaquim Nabuco que assinalava os riscos de que fosse introduzida no país uma nova classe de escravos. LESSER, Jeffrey. $O p$. cit. p. 56.

${ }^{31}$ Em São Paulo, os jornais Opinião Liberal, de Campinas, e Tribuna Liberal, da capital, fizeram intensa campanha em prol da importação de trabalhadores asiáticos. No entanto, no Pará, o A Provincia do Pará, órgão do Partido Liberal, não demonstrou o mesmo entusiasmo que os jornais paulistas. A explicação para isto talvez esteja no fato de que a proposta do Governo de introduzir asiáticos no país coincidiu com a chegada de grandes levas de nordestinos em Belém. Assim, entre 1877 e o início da década de 1880, mesmo os grupos imigrantistas do Pará passaram a apoiar a utilização dessa mão-de-obra em lugar da importação de trabalhadores estrangeiros.

${ }^{32}$ Para se ter uma idéia de como eram estas polêmicas, os debates parlamentares sobre a introdução de trabalhadores asiáticos no Brasil eram publicados nos jornais da seguinte forma: a Tribuna Liberal, que era favorável à proposta, publicava os discursos daqueles parlamentares que a defendiam, omitindo aqueles feitos em sentido contrário; enquanto isso, a Gazeta de Campinas respondia publicando somente estes últimos. Já o Partido Conservador de São Paulo e seus órgãos de imprensa se mantiveram distantes desses debates, imersos que estavam nas disputas entre os grupos liderados por Antônio Prado e João Mendes de Almeida.

${ }^{33}$ Ibidem. p. 169.
} 
autorizava o Governo a despender até duzentos e cinqüenta contos de réis com a importação de trabalhadores chineses. As tentativas de levar adiante este projeto e outras medidas no mesmo sentido, segundo Emília Viotti da Costa, ${ }^{34}$ acabaram se desvanecendo em virtude das resistências e oposição de vários parlamentares e associações como a Sociedade Brasileira de Imigração e a Sociedade Central de Imigração.

Sinimbu promoveu a publicação de trabalhos e conferências sobre assunto, ${ }^{35}$ além de nomear Antonio Moreira de Barros, que era favorável à introdução de asiáticos no país, para o Ministério dos Estrangeiros. Logo em seguida, o Governo apoiou a apresentação de um projeto de lei na Câmara dos Deputados, autorizando um crédito especial para enviar uma missão diplomática à China com o intuito de negociar a importação de trabalhadores. ${ }^{36}$ Dois outros componentes importantes desta estratégia foram as declarações do Presidente do Conselho de Ministros de que, em matéria de emancipação da escravatura, o Governo seguiria o princípio estabelecido na Lei do Ventre Livre, qual seja o de que a questão seria resolvida de maneira lenta, gradual e em respeito à propriedade, bem como no sentido de desfazer também as expectativas em relação à aprovação de qualquer medida no sentido de promover a imigração européia.

Apesar da resistência obstinada dos republicanos e de alguns parlamentares monarquistas, inclusive do próprio Partido Liberal, a Câmara dos Deputados aprovou rapidamente o envio da missão diplomática à China. ${ }^{37}$ Todavia, antes que esta legação seguisse o seu destino, os jornais informavam que uma comissão de parlamentares ingleses, representando a British and Foreign Anti-Slavery Society, pressionava o cônsul chinês em Londres a fim de que fosse proibida a emigração de compatriotas seus para os países que mantinham a escravidão, especialmente para o Brasil. Em 28 de setembro de 1879, exatamente na data do aniversário da aprovação da Lei do Ventre

\footnotetext{
${ }^{34}$ COSTA, Emília Viotti da. Da Senzala à Colônia. Op. cit., p. 169-170.

${ }^{35}$ TRABALHADORES asiaticos, Tribuna Liberal, 07/02/1880, Editorial. Além do livro de Salvador de Mendonça, o Presidente do Conselho de Ministros promoveu várias conferências sobre o assunto no Rio de Janeiro. TRABALHADORES asiaticos, Tribuna Liberal, 07/02/1880, Editorial.

${ }^{36}$ O BRASIL e a China, Tribuna Liberal, 21/02/1879, "Factos diversos". Antes mesmo da apresentação do projeto na Câmara dos Deputados, a Tribuna Liberal já informava que o Governo Imperial estava negociando com a China, através da embaixada brasileira em Londres, um tratado para a introdução de coolies.

${ }^{37}$ No dia 18 de setembro de 1879, o jornal Tribuna Liberal publicou uma pequena nota, informando que passara na Câmara dos Deputados, em $3^{\text {a }}$. discussão, o projeto que autorizava crédito extraordinário para enviar a missão diplomática à China. Ver: A MISSÃO á China, Tribuna Liberal, 18/09/1879, "Factos diversos".
} 
Livre, a Tribuna Liberal transcreveu da Gazeta de Notícias a representação enviada por aquela Sociedade às autoridades chinesas em Londres. Esta representação afirmava que em países onde existia a escravidão, nem cláusulas de contratos de trabalho nem leis impediriam que o trabalhador estrangeiro fosse escravizado. ${ }^{38}$

Ignorando estas dificuldades no plano internacional, os principais jornais vinculados ao Partido Liberal, como o Cruzeiro, do Rio de Janeiro, e a própria Tribuna Liberal, de São Paulo, procuraram secundar os esforços do Presidente do Conselho de Ministros, publicando relatos de viajantes e estudos técnicos que recomendavam o emprego de trabalhadores asiáticos na grande lavoura. Este último jornal, por exemplo, acompanhou toda a discussão do projeto de lei que autorizava o envio da missão diplomática à China, mas publicando somente os discursos do Ministro dos Estrangeiros, do deputado Martim Francisco Ribeiro de Andrada, que também fazia parte da redação do jornal, e dos demais deputados que eram favoráveis à proposta. ${ }^{39}$

Na Assembléia Legislativa Provincial de São Paulo, já em 1878, durante as discussões de um projeto de lei que dificultava a introdução de mais escravos na Província, o parecer de uma comissão de deputados nomeada para analisar esta proposta sugeria a introdução de trabalhadores asiáticos no país. Segundo os membros da comissão, sendo dificultada a aquisição de escravos, a Assembléia tinha o dever de auxiliar os fazendeiros a adquirir os braços que lhes faltariam, e que a melhor forma de assim proceder era promover a importação de trabalhadores asiáticos. ${ }^{40}$ Foi proposta, então, uma emenda ao projeto em discussão, autorizando o Governo a conceder aos fazendeiros a quantia de 50 mil réis por trabalhador asiático que importassem, não excedendo a quantia anual de 50 contos de réis. ${ }^{41}$

Em 1879, o deputado Antonio Pinheiro de Ulhôa Cintra, um dos integrantes daquela comissão, apresentou um projeto de lei autorizando o Governo a despender a quantia de 250 contos de réis para a introdução de mil trabalhadores asiáticos na

\footnotetext{
${ }^{38}$ VÃOS receios. Tribuna Liberal, 28/09/1879, "Factos diversos".

39 Os jornais republicanos, como a Gazeta de Campinas e A Provincia de São Paulo, por seu turno, publicavam os discursos dos deputados que eram contrários ao projeto.

${ }^{40}$ Anais da Assembléia Legislativa Provincial de São Paulo [doravante, AALPSP], 1878, 34 a sessão, 27 de março, p. 471.

${ }^{41}$ A Comissão era formada pelos deputados Joaquim Egydio de Sousa Aranha (Barão de Três Rios), Joaquim José Vieira de Carvalho, Antonio Pinheiro de Ulhôa Cintra, Cesario N. de Azevedo Motta Junior e Francisco de Paula Rodrigues Alves. Destes, o penúltimo assinou o parecer "com restrições" e o último como "vencido", mas não explicaram as razões. É possível que fossem contrários à proposta, principalmente Cesário N. de Azevedo Motta Junior, que era deputado republicano.
} 
Província. ${ }^{42}$ Embora tenha sido aprovado em primeira discussão sem debates, somente na legislatura seguinte, constituída unicamente por deputados do Partido Liberal, o projeto seria debatido. ${ }^{43}$ Logo na $2^{a}$ sessão ordinária, realizada no dia 7 de fevereiro de $1880,{ }^{44}$ ele entrou em segunda discussão, mas, devido a um requerimento do deputado Antonio José Ferreira Braga, a proposta foi encaminhada para ser examinada pela Comissão de Fazenda da Assembléia. A justificativa apresentada por este deputado era de que se tratava de um projeto que envolvia interesses importantíssimos e que os recursos previstos onerariam o tesouro. Entretanto, o emprego de medidas protelatórias como esta, eram recursos muito utilizados quando se desejava ganhar tempo para, num momento mais oportuno, rejeitar o projeto em questão.

No dia 11 de março, durante a $24^{a}$. sessão, os cinco deputados que constituíam a comissão de fazenda apresentaram um parecer, no qual afirmavam que era de “incontestável vantagem” a introdução de trabalhadores asiáticos no país, pois somente eles poderiam de pronto substituir os escravos e salvar o país da crise que estava iminente em decorrência dos efeitos da Lei do Ventre Livre. Além disso, os deputados afirmaram que os chineses eram impropriamente confundidos com os coolies, sendo, ao contrário destes, trabalhadores sóbrios, laboriosos e pacientes. ${ }^{45}$

Todavia, mesmo apoiando a introdução de trabalhadores asiáticos no país, a comissão recusou o projeto por considerá-lo oneroso aos cofres públicos e também porque seria de difícil execução e até desnecessário, uma vez que exigia contrato direto com a América do Norte ou com a Ásia, e o Governo Imperial já estava negociando, no mesmo sentido, com a China. A comissão apresentou, então, um projeto substitutivo, ${ }^{46}$ que determinava basicamente o seguinte: feito o contrato entre os governos do Brasil e da China, a presidência da Província ficaria encarregada de providenciar a hospedagem dos imigrantes procedentes deste último país; o fazendeiro que quisesse contratá-los indenizaria a Província de todas as despesas feitas com a aquisição e alojamento dos mesmos; o Governo providenciaria de modo que, salvo imprevistos, nunca faltasse trabalhadores na hospedaria e que, por outro lado, o número deles nunca excedesse a

${ }^{42}$ AALPSP, 1879, 29 $9^{\mathrm{a}}$. sessão ordinária, 27 de março, p. 247.

${ }^{43}$ Para ser aprovado um projeto de lei devia ser aprovado em três discussões. Depois disso ainda podia ser vetado pelo Presidente da Província. Nesse caso, somente dois terços dos votos da Assembléia podiam anular o veto. AALPSP, $1879,33^{\text {a }}$. sessão ordinária, 1 de abril, p. 342.

${ }^{44}$ AALPSP, 1880, 2 ${ }^{\mathrm{a}}$. sessão ordinária, 07 de março, p. 7.

${ }^{45}$ AALPSP, 1880, 24 ${ }^{\text {a }}$. sessão ordinária, 11 de março, p. 195.

${ }^{46}$ Ibidem. p. 195-196. 
500; o Governo ficava autorizado a fazer as operações de crédito necessário e despender até a quantia de 120 contos de réis com a aquisição dos trabalhadores, aluguel de casas, obras necessárias etc.

A primeira discussão deste novo projeto teve início no dia 16 de março, prolongando-se pelas sessões dos dias 17 e 18 de março, 13 e 14 de abril. ${ }^{47}$ Ao final desta última, procedendo-se à votação, o projeto foi aprovado. Como faltavam apenas três dias para o encerramento dos trabalhos da Assembléia naquele ano, a segunda discussão deveria ser realizada em 1881, mas isto não ocorreu.

É possível que um dos fatores tenha sido as dificuldades que os adeptos da medida encontraram para aprovar o projeto em primeira discussão. Durante os debates, cinco deputados ocuparam a tribuna, sendo que dois eram contrários à aprovação do mesmo e três favoráveis. Porém, levando em conta os apartes que foram dados aos discursos destes deputados, sete se pronunciaram contra e apenas cinco a favor. Todavia, como a votação realizada ao final da primeira discussão foi secreta, é impossível sabermos até que ponto estes números podem ser tomados como um indício de que o projeto seria rejeitado nas discussões seguintes.

Um dado importante acerca desta proposta é que a sua execução dependia da realização do acordo entre os governos do Brasil e da China. Este ponto, aliás, foi matéria de discussão entre o deputado João Alves de Siqueira Bueno, que era contrário à proposta, e o deputado Antonio José da Costa Junior, que assumiu a autoria do projeto. ${ }^{48}$ De acordo com o primeiro, além de impor uma grande despesa à Província, $\mathrm{o}$ projeto em questão era totalmente desnecessário visto que o Governo Geral havia tomado a si a introdução dos trabalhadores asiáticos no país. ${ }^{49} \mathrm{O}$ autor do projeto procurou mostrar, então, que o mesmo não oneraria os cofres públicos porque o artigo $2^{\circ}$. estabelecia que os agricultores que contratassem os trabalhadores indenizariam a Província de todas as despesas feitas com a aquisição e alojamento até o dia da entrega.

Mais adiante, porém, devido à insistência de alguns deputados de que a execução do projeto dependeria da assinatura do tratado entre o Brasil e a China, os deputados Ingles de Souza e Romeiro entraram em divergência, porque este último

\footnotetext{
${ }^{47}$ AALPSP, 1880, 29ª . sessão ordinária, 17 de março, p. 261-267; 30ª sessão ordinária, 18 de março, p 277-290; 49a . sessão ordinária, 13 de abril, p. 465-470; 50ª . sessão ordinária, 14 de abril, p. 478-483.

${ }^{48}$ Idem, $29^{a}$. sessão ordinária, 17 de março, p. 264.

${ }^{49}$ Idem, p. 278.
} 
afirmou que a medida era uma forma de apoio a Sinimbu, ao que Ingles de Souza respondeu afirmando que era melhor uma homenagem ao governo que caía do que ao que subia. ${ }^{50}$ Os deputados se referiam à destituição do Gabinete Sinimbu, ocorrida no dia 7 de março de 1880, o que explica a ênfase no fato de a execução do projeto depender da assinatura do tratado entre o Brasil e a China. Os deputados sabiam que a substituição de Sinimbu na presidência do Conselho de Ministros poderia interferir nas negociações para a introdução de trabalhadores asiáticos no país. Tanto assim que a primeira discussão do projeto foi interrompida no dia 18 de março e só retomada em 14 de abril, quando o programa do novo ministério, cuja posse se deu em 28 de março, já havia sido divulgado.

A introdução de trabalhadores asiáticos no país sequer fazia parte do programa oficial do Gabinete Sinimbu, que tinha sido formado com a incumbência principal de realizar a reforma da eleição direta. Mas sua opinião sobre o assunto já era conhecida e talvez fosse uma estratégia adotada pelo Presidente do Conselho de Ministros para obter o apoio dos grandes proprietários rurais, que, apesar de não ter sido capaz de fortalecer o Governo para a reforma constitucional, pelo menos em São Paulo conquistou muitos adeptos. Tanto que em 1888, dez anos depois de sua passagem pelo ministério, um antigo redator do jornal Opinião Liberal, Polycarpo de Queiroz, publicou um livro intitulado Transformação do Trabalho, dedicado ao "patriótico Ministério de 5 de Janeiro de 1878", no qual defendia a introdução de asiáticos no país. ${ }^{51}$

Assim, além das dificuldades interpostas pelo governo inglês, a demissão do Gabinete Sinimbu dificultou muito a introdução de trabalhadores asiáticos no país. Entretanto, as notícias que os jornais publicavam sobre os conflitos que ocorriam na Califórnia entre os imigrantes chineses e a população local, provavelmente incentivaram alguns fazendeiros a enviar representantes aos Estados Unidos na esperança de contratálos. Entre estes, estava um dos mais importantes cafeicultores de Campinas, Joaquim Bonifácio do Amaral, o Visconde de Indaiatuba, que desde o início da década de 1850 empregava trabalhadores europeus em suas fazendas.

Em 1870, numa polêmica amistosa com José Vergueiro, filho do famoso Senador Vergueiro e precursor da utilização de imigrantes europeus na cafeicultura paulista, o então Barão de Indaiatuba havia rejeitado o emprego de trabalhadores

\footnotetext{
${ }^{50}$ AALPSP, 1880, 30 . sessão ordinária, 18 de março, p. 289.

${ }^{51}$ QUEIROZ, Polycarpo de. Transformação do Trabalho. Campinas: Castro Mendes, 1888.
} 
asiáticos mesmo como "meio de transição". Mas as greves de colonos europeus ocorridas em suas fazendas, em meados dos anos 1870, talvez tenham feito com que ele mudasse de opinião, assim como interesses de natureza político-partidária. Joaquim Bonifácio do Amaral era líder proeminente do Partido Liberal em Campinas, um dos fundadores do Clube da Lavoura local e, de acordo com os republicanos da Gazeta de Campinas, um dos principais acionistas da associação comanditária que sustentava o jornal Opinião Liberal.

Em pouco tempo, porém, a esperança destes agricultores de contratar trabalhadores chineses nos Estados Unidos também se desvaneceu. Os boatos largamente difundidos sobre a abundância desta mão-de-obra na Califórnia, assim como sobre o seu baixo custo, não resistiram a uma avaliação mais cuidadosa. Enquanto alguns jornais ainda noticiavam a formação de associações interessadas em contratá-los na China, a cinco dólares mensais, ou nos Estados Unidos, a dez ou quinze dólares, chegavam informações da Califórnia de que a quantidade de chineses na região era muito menor do que se supunha e que o seu salário mensal chegava a trinta ou quarenta dólares.

Dessa forma, vencido o principal argumento dos adeptos da importação de asiáticos, ou seja, o baixo custo dessa mão-de-obra, que teria grande força de persuasão num momento em que a economia cafeeira passava por uma crise de preços, a maioria deles desistiu desta alternativa. Em 1883, contudo, quando os preços do café voltaram a subir, uma nova tentativa seria feita. Os jornais noticiaram com alarde a chegada ao Rio de Janeiro de Tong King Sing, diretor-gerente da Merchant's Steam Navigation Company, cuja intenção seria negociar com o governo brasileiro uma subvenção de cem mil dólares para o estabelecimento de uma linha de vapores entre a China e o Brasil para facilitar a introdução de trabalhadores chineses no Brasil. ${ }^{52}$

Mas àquela altura, quando o movimento abolicionista ganhava as praças das principais cidades e as páginas dos jornais, as negociações com Tong King Sing foram consideradas uma estratégia dos grandes proprietários para prolongar a vida da escravidão. Isto teria sido percebido pelo empresário chinês, que partiu subitamente sem

\footnotetext{
${ }^{52}$ De acordo com Jeffrey Lesser, o nome verdadeiro de Tong King Sing ou Tong King-shu, como aparece nos jornais e documentos brasileiros, era T'ang T'ing-shu, um rico empresário de Cantão, cujo secretário, G. C. Butler, um negro norte-americano que vivia em Xangai, fora contatado pelo diplomata brasileiro Eduardo Callado, interessado em enviar chineses para o Brasil e café, tabaco e madeira para os Estados Unidos. LESSER, Jeffrey. Op. cit. p. 58-59.
} 
dar explicações. ${ }^{53}$ A Sociedade Central de Imigração, cujos fundadores advogavam a substituição da grande propriedade por um regime de pequenas propriedades com mãode-obra familiar, preferencialmente alemã ou italiana, também contribuiu para o fracasso de mais uma tentativa de introdução de trabalhadores asiáticos no país. Sua primeira diretoria, composta pelo General Henrique de Beaurepaire Rohan, Alfredo de Escragnolle Taunay e André Rebouças, entre outros, protestou com veemência contra o que chamavam de tentativa de substituir a escravidão negra pela escravidão amarela. ${ }^{54}$

Estas e outras pressões parecem ter dado resultado, pois, apesar de continuarem existindo adeptos da imigração asiática para o Brasil, em 1890 o Congresso Nacional proibiu toda e qualquer entrada asiáticos, bem como de africanos, no país sem a sua aprovação. ${ }^{55}$ Tornava-se, assim, expressa a preferência pelos europeus da parte da maioria dos setores envolvidos no debate sobre o processo de reorganização do mercado de trabalho no país ou, pelo menos, daqueles setores que conseguiam se articular politicamente e fazer valer os seus interesses.

Nosso intuito ao analisar as tentativas de introdução de trabalhadores asiáticos foi demonstrar que, em determinados momentos, os partidos políticos tinham propostas específicas para resolver o problema do suprimento de braços para as lavouras. Isto revela o quão politizado estava o debate sobre a questão da reorganização do mercado de trabalho, durante as décadas de 1870 e 1880. Além disso, a julgarmos pela pouca repercussão do assunto no Pará, revela também que determinadas propostas se apresentavam como mais prováveis para uma região do que para outras. Em São Paulo, pelo menos, vários fazendeiros, políticos e redatores de jornais consideraram como muito provável a importação de chineses ou coolies. Já no Pará, um fator circunstancial - a chegada de grandes levas de migrantes nordestinos, a partir de 1877 - pode ter determinado a fraca receptividade à proposta do Partido Liberal.

\footnotetext{
${ }^{53}$ Segundo Jeffrey Lesser, numa conversa com D. Pedro II, ao ficar sabendo que as negociações teriam de ser feitas diretamente com os fazendeiros, pois o governo não subvencionaria a vinda de chineses, o empresário teria dito que não aceitaria o perverso sistema de contratos oferecidos aos coolies e que só concordaria em negociar a introdução de "imigrantes livres" no país. Para Jeffrey Lesser, porém, o principal motivo da desistência de Tong King Sing pode ter sido um chamado de seu patrono político e comercial, Li Huang-chang, envolvido em hostilidades contra a França. LESSER, Jeffrey. Ibidem. p. 61.

${ }^{54}$ Os grandes proprietários haviam fundado uma Companhia de Comércio e Imigração Chinesa, em 1880, a qual foi dissolvida pouco depois da partida precipitada de Tong King Sing. CARNEIRO, José Fernando. Fazendeiros na História do Brasil. Província de São Pedro, Porto Alegre, 11 (21):32-52, dez. 1957. p. 43. COSTA, Emília Viotti da. Da Senzala à Colônia. Op. cit. p. 171.

${ }^{55}$ LESSER, Jeffrey. Op. cit. p. 63.
} 
O debate sobre a introdução de asiáticos no país nos permite conhecer, também, um pouco mais a respeito do imigrante idealizado pelas elites políticas. Mesmo aqueles que os consideravam uma alternativa viável para a substituição dos escravos, não tinham os asiáticos na conta dos povos que poderiam contribuir positivamente para a formação nacional. É possível que se tratasse apenas de um expediente para convencer os mais recalcitrantes, mas impressiona o fato de muitos dos adeptos da alternativa asiática enfatizar que se tratava de uma imigração temporária e que, portanto, não se miscigenaria. Algumas das características atribuídas a eles - como a de se sujeitarem a qualquer trabalho e de aceitarem baixos salários - nos permitem uma comparação interessante com os europeus, tidos como trabalhadores exigentes, e com os trabalhadores que existiam no país. Asiáticos, índios e escravos pareciam ocupar o mesmo patamar na escala de civilização dos políticos e redatores de jornais: eram indolentes, pouco inteligentes, biologicamente degenerados, imorais, submissos e acomodados.

Não é mera coincidência o fato de características negativas atribuídas ao europeu serem encontradas entre as características positivas atribuídas aos asiáticos e vice-versa. Considerava-se problemático, por exemplo, que os imigrantes europeus não se sujeitassem - ou não suportassem - a trabalho árduo, sob condições naturais e climáticas adversas; que fossem ambiciosos, ou seja, que desejassem se tornar proprietários e ascender socialmente. Assim comparados, poderíamos perguntar: por quê o asiático não era preferido em relação ao europeu?

A comparação entre as características atribuídas aos europeus e aos asiáticos evidencia que as elites do século XIX, em geral, estabeleciam uma separação entre o imigrante tido apenas como trabalhador daquele considerado sob o ponto de vista da formação do povo e da cultura. Dos trabalhadores desejavam-se principalmente características projetadas no imigrante asiático: baixa exigência em termos de salários e condições de trabalho. Nesse sentido, o recurso aos asiáticos se apresentava como uma escravidão dissimulada, ainda que muitos o considerassem um "meio termo" entre o escravo e o homem livre.

Todavia, quando se tratava de discutir o imigrante do ponto de vista da sua contribuição para a formação étnica e cultural do povo brasileiro, desejavam-se características muito diferentes de algumas projetadas no asiático. Podemos encontrá-las 
quando os políticos e redatores de jornais se referiam ao imigrante europeu. A razão disso era que deste imigrante se esperava uma sujeição apenas temporária ao trabalho assalariado, pois sua vocação natural seria se tornar proprietário. Isto demonstra que as elites do final do oitocentos ainda não vislumbrava no trabalho assalariado uma atividade dignificante.

\subsection{O índio: “civilização" e extermínio}

A opinião do Barão de Mauá de que era mais viável o emprego da mão-de-obra indígena do que a de imigrantes nas colônias estabelecidas no Vale Amazônico não era compartilhada pela maioria dos presidentes de província. Entretanto, como eram responsáveis pelo "Serviço de Catequese e Civilização dos índios", eles se viam obrigados a discutir nos relatórios e falas a situação dos aldeamentos, ${ }^{56}$ as demandas dos índios e a maneira como proceder em relação aos mesmos. Alguns deles, no entanto, sobretudo nos períodos mais críticos do processo de reorganização do mercado de trabalho, aventaram a possibilidade de os aldeamentos se transformarem em centros formadores de mão-de-obra para a lavouras.

De acordo com Roberto Santos até 1877 todos ou quase toda a mão-de-obra utilizada na extração e preparo da goma elástica era indígena. ${ }^{57} \mathrm{~A}$ partir de então, grandes levas de cearenses começaram a chegar ao Vale Amazônico, o que não impediu a continuidade da prática dos "descimentos", iniciada no período colonial, que teria se prolongado até o início do século XX. Assim, a partir daquele ano, índios e tapuios habitantes de origem indígena - formavam, juntamente com os migrantes nordestinos, o grande contingente de trabalhadores da borracha. ${ }^{58}$

\footnotetext{
${ }^{56}$ A adoção de uma política de aldeamentos data do século XVI, quando o padre Manoel da Nóbrega percebeu os limites da ação missionária itinerante. Com a política de aldeamentos houve uma inversão nessa prática, pois ao invés dos padres foram os indígenas que tiveram de se deslocar para áreas determinadas pela Coroa, onde eram obrigados a adotar costumes cristãos e, sobretudo, sedentarizar-se por meio do trabalho agrícola. Ao processo através do qual o índio era capturado ou convencido a se deslocar para um aldeamento, que geralmente ficava situado nas proximidades de uma vila ou engenho, dava-se o nome de "descimento", sendo os termos "redução" e "resgate" geralmente empregados para designar o que se daria a partir disso, ou seja, a aculturação e, muitas vezes, a escravização. VAINFAS, Ronaldo (dir.). Dicionário do Brasil Colonial. 1500-1808. Rio de Janeiro: Objetiva, 2000. p. 21-24.

${ }^{57}$ SANTOS, Roberto. Op. cit. p. 61-63.

58 Em 1892, José Verissimo assinalava que a mão-de-obra utilizada na extração da borracha era principalmente a dos cearenses, dos tapuios e dos mamelucos. Os tapuios, na sua concepção, eram índios "meio civilizados" ou "semi-selvagens", enquanto mamelucos seriam os descendentes da miscigenação
} 
A análise dos relatórios indica que os administradores discutiam as possibilidades de aproveitamento do índio na agricultura apenas nos momentos mais críticos do processo de reorganização do mercado de trabalho, ou seja, quando a abolição da escravatura parecia iminente e as perspectivas de encontrar uma fonte estável de suprimento de braços não eram animadoras. No final da década de 1860, por exemplo, após tentativas frustradas de estabelecer imigrantes norte-americanos em Santarém, Joaquim Raymundo de Lamare ${ }^{59}$ sugeriu a catequese e "civilização" de índios, juntamente com a adoção de medidas para aproveitar a mão-de-obra das pessoas "úteis e dignificantes", que estariam à mercê da "perniciosa influência da ociosidade e do desleixo", como forma de solucionar o problema de braços no Pará. ${ }^{60}$ Da mesma forma, o Vice-Presidente Abel Graça, criticando o fato de o extrativismo absorver o trabalho de muitos índios aldeados na Província, assim como no Maranhão e Amazonas, argumentou que a catequese era uma alternativa de suprimento de mão-de-obra mais viável do que a colonização estrangeira, pois o índio não teria de passar pelo problema da adaptação às condições naturais do país. ${ }^{61}$

Mas a maioria dos presidentes acreditava que o indígena só poderia ser utilizado na agricultura após sua "catequese e civilização", o que significava reuni-los em aldeamentos administrados por funcionários do governo, assistidos por missionários e professores. Não estava claro, contudo, o que seria feito com eles nos aldeamentos, ou seja, nenhum dos relatórios analisados deixa entrever que houvesse da parte dos administradores provinciais propostas mais acabadas sobre como transformar o índio em produtor agrícola ou em mão-de-obra para as lavouras. Nesse sentido, alguns

entre índios e brancos, também chamados de curibócas. Na sua origem, a palavra tapuia não constituía um etnônimo, sendo utilizada pelos tupis para designar povos que possuíam línguas e culturas diversas. Carlos de Araújo Moreira Neto, que analisou a participação dos tapuios na Cabanagem, atribuiu a José Verissimo a distinção entre este grupo indígena e as "raças cruzadas". VERISSIMO, José. Estudos Amazônicos. Belém: Universidade Federal do Pará, 1970. p. 178; MOREIRA NETO, Carlos de Araújo. Índios da Amazônia. De maioria a minoria (1750-1850). Petrópolis (RJ): Vozes, 1988. p. 48-49; VAINFAS, Ronaldo (dir). Op. cit. p. 544.

${ }^{59}$ Pará. Relatorio com que o excellentissimo senhor Vice-Almirante e Conselheiro de Guerra Joaquim Raymundo de Lamare passou a administração da Provincia do Gram-Pará ao excellentissimo senhor Visconde de Arary, $1^{o}$. Vice-Presidente, em 6 de agosto de 1868. Belém: Typ. do Diario do Gram-Pará, 1868 , p. 5.

${ }^{60}$ Um Administrador sugeriu também a utilização de prisioneiros paraguaios nos serviços de limpeza e medição das terras. Ver: Pará. Relatorio com que o excelentissimo senhor conego Manuel José de Siqueira Mendes primeiro Vice-Presidente da Provincia do Pará passou a administração da mesma ao excelentissimo senhor Presidente João Alfredo Corrêa de Oliveira. Belém: Typographia do Diario do Gram-Pará, 1870, p. 6.

${ }^{61}$ Pará. Relatorio apresentado a Assembléa Legislativa Provincial na primeira sessão da $17^{a}$. legislativa, pelo quarto Vice-Presidente Dr. Abel Graça. Belém: Typ. do Diario do Gram-Pará, 1870, p. 28-42. 
presidentes chegaram a afirmar que a catequese não era tão necessária e que a "civilização" podia ser feita fora dos aldeamentos, pelo contato puro e simples dos índios com aqueles que exploravam a floresta.

Em 1874, Pedro Vicente de Azevedo afirmou que, na região do rio Capim, muitos índios vinham sendo utilizados indevidamente na extração de óleo da copaíba e casca do cravo, ${ }^{62}$ o que o levara a organizar um aldeamento para quatrocentos índios Tembê, empregados na plantação de mandioca, milho, arroz e tabaco. Entretanto, certos "descuidos na administração do aldeamento" teriam feito com que eles voltassem à coleta de especiarias, obrigando o administrador a enviar um missionário para gerir o aldeamento. $^{63}$

Em novo relatório, Pedro Vicente de Azevedo mudou radicalmente seu ponto de vista acerca do assunto. ${ }^{64}$ Segundo ele, dentre os três "agentes de civilização dos índios" - o missionário, o regatão e o diretor - a ação dos dois primeiros não teria produzido nenhum benefício notável, pois o Governo não tinha recursos suficientes para criar e manter aldeamentos. Assim, os missionários se limitavam a realizar o trabalho espiritual e a explorar a mão-de-obra indígena nas próprias aldeias, o que do ponto de vista do Presidente não contribuía para a sua "civilização". Da mesma forma, os diretores também se viam obrigados a explorar a força de trabalho dos índios, mas em benefício próprio. Assim, o mais útil agente de civilização seria o regatão, anteriormente criticado pelo administrador, pois sua "cobiça imoral", apesar de "infeccionar" as margens dos rios com os "germes da corrupção", abria a machado o caminho da "civilização", desde os sertões até a capital. ${ }^{65}$

Na concepção de Pedro Vicente de Azevedo, "civilizar" o índio significava despi-lo dos seus "hábitos indolentes" para que pudesse ser aproveitado nos trabalhos "incontínuos e não inspecionados", ou seja, transformá-los em trabalhadores úteis, que pudessem sustentar a si mesmos e à sociedade dita civilizada. O mesmo teria de ser feito em relação aos trabalhadores livres existentes na região. Acreditava o Presidente da

\footnotetext{
${ }^{62}$ Pará. Relatorio apresentado à Assembléa Legislativa Provincial na primeira sessão da $19^{a}$ legislatura pelo Presidente da Provincia do Pará o excellentissimo senhor doutor Pedro Vicente de Azevedo em 15 de fevereiro de 1874. Belém: Typ. do Diario do Gram-Pará, 1874.

${ }^{63}$ De acordo com Pedro Vicente Azevedo, esta providência fez com que a produção realizada pelos índios voltasse a ser remetida para a capital da Província. Ibidem. p. 47.

${ }^{64}$ Pará. Relatório Apresentado ao exm. senr. Dr. Francisco Maria Corrêa de Sá e Benevides pelo exm. senr. Dr. Pedro Vicente de Azevedo por occasião de passar-lhe a Administração da Provincia do Pará, no dia 17 de janeiro de 1875. Belém: Typ. de F. C. Rhossard, 1875.

${ }^{65}$ Ibidem. p. 55-57.
} 
Província que, devido sua origem indígena, o homem livre pobre do Vale Amazônico não se submeteria a qualquer trabalho "suspeito de obrigatório", adaptando-se melhor às atividades com as quais estava acostumado, ou seja, a coleta de produtos naturais. Quanto ao trabalho missionário, embora fosse incapaz de civilizar o índio, era necessário, pois o culto religioso evitaria que os índios, "amantes das festividades religiosas", abandonassem os aldeamentos localizados em freguesias desprovidas de padres. $^{66}$

As concepções de Pedro Vicente Azevedo não eram muito diferentes daquelas expressadas pela maioria dos administradores da Província de São Paulo. ${ }^{67}$ No início da década de 1870, Antonio da Costa Pinto Silva registrou em seu Relatório que um aldeamento indígena havia sido abandonado após a transferência do seu capelão para a Província do Paraná, determinada pelo Governo Imperial, e também em virtude do assassinato do "capitão" dos índios. ${ }^{68}$ Pedro Vicente Azevedo e Antonio da Costa Pinto Silva talvez considerassem o trabalho dos religiosos nos aldeamentos como um mal necessário, em virtude da impossibilidade de o Governo assumir o controle do "processo civilizatório", que ali teria de ser desenvolvido para que o índio pudesse ser transformado em mão-de-obra útil.

Conforme ressaltou Carlos de Araújo Moreira Neto, havia uma constante luta envolvendo as missões religiosas pós-pombalinas (carmelitas, franciscanos, capuchinhos etc.), os agentes oficiais e comerciantes pelo controle dos grupos indígenas. Estes embates eram travados diretamente ou através de "capitães" e outros prepostos, provocando, em contrapartida, muitas revoltas dos grupos indígenas, que buscavam sobreviver como uma sociedade independente, a exemplo dos "índios misioneros" do Sul do Brasil. ${ }^{69}$ Os presidentes de província às vezes consideravam os índios dóceis, outras vezes bárbaros que se contrapunham a um inevitável processo

\footnotetext{
${ }^{66}$ Ibidem. p. 60-63.

${ }^{67}$ Analisando os relatórios que os ministros da agricultura produziram entre 1862 e 1892, Mary Karasch notou as mesmas concepções, que segundo ela remontavam aos programas de aldeamento do século XVIII. Não havia da parte das autoridades, observou a autora, uma intenção de ir além e, por exemplo, inovar políticas de terras ou de trabalho que poderiam ter fortalecido as populações indígenas. KARASCH, Mary. Catequese e cativeiro. Política indigenista em Goiás: 1780-1889. Trad. Beatriz Perrone-Moyses. In: CUNHA, Manuela Carneiro da (org.). História dos Índios no Brasil. 2a ${ }^{\mathrm{a}}$. ed. São Paulo: Companhia das Letras; Fapesp; Secretaria Municipal de Cultura, 1992. p. 406.

${ }^{68}$ São Paulo. Relatório apresentado á Assembléa Legislativa Provincial de S. Paulo pelo Presidente da Província o Exm. Sr. Dr. Antonio da Costa Pinto Silva no dia 5 de fevereiro de 1871. S. Paulo: Typ. Americana, 1871. p.27-28.

${ }^{69}$ MOREIRA NETO, Carlos Araújo. Op. cit. p. 50.
} 
civilizatório. Em ambos os casos, justificavam a ação do Estado pela necessidade de converter os "infelizes" ou as "feras" em elementos úteis para a sociedade. O problema era que nem a ação dos diretores nem a dos missionários apresentavam resultados satisfatórios.

A crítica de Pedro Vicente de Azevedo à ação dos diretores foi reiterada por seu sucessor na Presidência da Província do Pará, Francisco Maria Corrêa de Sá e Benevides. De acordo com este, os diretores pouco faziam em benefício dos aldeamentos sob sua responsabilidade, pois muitos deles sequer residiam no local. $\mathrm{O}$ resultado disso era que os índios permaneciam em seu “estado primitivo”. Já em relação aos missionários, Francisco Benevides afirmou que o maior problema era o número insuficiente deles para atender às três missões existentes no Pará. Quanto ao regatão, reiterou as críticas do anterior, mas sem reconhecer na sua atividade um "meio de civilização". ${ }^{70}$

Tanto os Relatórios dos presidentes do Pará com os dos presidentes de São Paulo assinalaram o estado de abandono em que se encontravam os aldeamentos indígenas de ambas as Províncias. Os problemas apontados eram os mais variados. João Capistrano Bandeira de Mello Filho, por exemplo, ${ }^{71}$ culpou a falta de recursos e a "instabilidade das administrações", ou seja, as sucessivas substituições de presidentes de província, que dificultariam a adoção e continuidade de uma política de "catequese e civilização" dos índios. O Governo Imperial, de acordo com este Presidente, destinava uma grande verba para o serviço, mas no Pará não se conseguia manter um número suficiente de catequizadores. Em razão disso, os aldeamentos não prosperavam e os índios, ao invés de se dedicarem à lavoura, preferiam o serviço de extração de madeiras e a coleta dos produtos da floresta. ${ }^{72}$

\footnotetext{
${ }^{70}$ Pará. Relatorio apresentado pelo exm. sr. dr. Francisco Maria Corrêa de Sá e Benevides, Presidente da Provincia do Pará, á Assembléa Legislativa Provincial na sua sessão solemne de installação da 20.a legislatura, no dia 15 de fevereiro de 1876. Pará, 1876. p. 41-42.

${ }^{71}$ Pará. Falla com que o exm. sr. dr. João Capistrano Bandeira de Mello Filho abrio a 2.a sessão da 20.a legislatura da Assemblea Legislativa da provincia do Pará em 15 de fevereiro de 1877. Pará, Typ. do Livro do Commercio, 1877. p. 164.

${ }^{72}$ Pará. Relatorio com que ao exm. sr. Dr. José da Gama Malcher, $1^{o}$. Vice-Presidente passou a administração da Provincia do Pará o exm. sr. Dr. João Capistrano Bandeira de Mello Filho em 9 de março de 1878. Belém: Typ. Guttemberg, 1878, p. 103-104. O serviço de catequese dos índios era conduzido por um diretor geral e vários diretores parciais, nomeados pelo Presidente da Província após indicação do diretor geral. Em 1878, havia 12 diretorias parciais; os ocupantes destes cargos deviam prestar informações sobre a situação do aldeamento.
} 
Em São Paulo os problemas pareciam ser mais graves. Em 1871, Antonio da Costa Pinto Silva ${ }^{73}$ afirmou que, dos aldeamentos existentes, o S. João Baptista e o Itarery estavam em estado precário e o Tijuco-Preto, Pinheiros, Mboy, Carapucuhyba, Baruery, S. Miguel, Itaquaquecetuba, Escada e S. João de Queluz sequer deviam ser considerados como tais, pois os índios haviam sido expulsos dos terrenos ou abandonado o local. Alguns anos mais tarde, ${ }^{74}$ baseando-se em um relatório elaborado pelo Brigadeiro Luiz Joaquim de Castro, Diretor Geral dos Índios, João Theodoro Xavier reiterou o ponto de vista de Antonio da Costa Pinto e Silva.

Esta situação repercutia até na capital da Província. João Theodoro Xavier registrou em seu Relatório que dez índios da "raça guarany", moradores nas vizinhanças do aldeamento S. Sebastião do Tijuco-Preto, haviam lhe procurado para solicitar instrumentos de lavoura e outros objetos que necessitavam. Além deles, outros 14 indígenas, do aldeamento São João Batista, solicitaram ajuda do Brigadeiro Diretor Geral, que lhes forneceu roupas e outros utensílios. Por outro lado, as "correrias" de índios pareciam freqüentes em algumas regiões. Em Junho de 1875 teria ocorrido no aldeamento S. João Baptista um "grave conflito", resultando na morte de duas pessoas e ferimento de quatro. ${ }^{75}$

Alguns anos mais tarde, o Presidente Laurindo Abelardo de Brito solicitou da Assembléia Legislativa Provincial de São Paulo uma quota para ser empregada na compra de "agasalhos" e "instrumentos úteis" a alguns indígenas que "em períodos certos" se apresentavam na capital para solicitar auxílio do Governo. Como não havia autorização para despesas desse tipo no orçamento, nem sempre era possível atendê-los. Nessas situações, os índios acabavam vagando pelas ruas da capital, à mercê da

\footnotetext{
${ }^{73}$ São Paulo. Relatorio apresentado á Assembléa Legislativa Provincial de S. Paulo pelo Presidente da Província o Exm. Sr. Dr. Antonio da Costa Pinto Silva no dia 5 de fevereiro de 1871. S. Paulo: Typ. Americana, 1871. p.27-28.

${ }^{74}$ Em 1874, João Theodoro Xavier mencionou um relatório elaborado pelo Diretor Geral dos Índios, Brigadeiro Luiz Joaquim de Castro Carneiro Leão, mas este não foi anexado na versão de consultamos do Presidente da Província. O trecho em que há a referência é o seguinte: "Faço remissão sobre este assunto ao relatório sob n. 26 do Diretor Geral dos Índios, Brigadeiro Luiz Joaquim de Castro Carneio Leão". Ver: São Paulo. Relatorio apresentado a Assembléa Legislativa Provincial de S. Paulo pelo Presidente da Província o Exm. Sr. Dr. João Theodoro Xavier em 5 de fevereiro de 1874. S. Paulo: Typ. Americana, 1874. p.40.

${ }^{75}$ São Paulo. Relatorio apresentado a Assembléa Legislativa Provincial de S. Paulo pelo Exm. Sr. Dr. João Theodoro Xavier Presidente da Província no dia 14 de fevereiro de 1875. S. Paulo: Typ. do Diário, 1875. p.100.
} 
caridade pública, até retornarem ao seu local de origem. ${ }^{76}$ Entretanto, o Barão de Guajará, Domingos Antônio Rayol, natural do Pará, criticou a Assembléia Legislativa de São Paulo, quando administrou a Província, por não destinar verba no orçamento para que a administração pudesse atender os índios que se deslocavam até a capital, para solicitar do governo ferramentas e outras providências. ${ }^{77}$

Apesar disso, alguns administradores pareciam encontrar meios para fornecer auxílio aos índios que os procuravam. O conselheiro Francisco de Carvalho Soares Brandão extraiu do orçamento a quantia de $60 \$ 000$ para entregar a três deles, que haviam se deslocado do Salto Grande do Paranapanema até a capital a fim de solicitar ajuda. Em outra oportunidade, mais de trinta índios guaranis, residentes no município da Conceição de Itanhaem, foram à capital para reclamar a concessão de algumas terras, que afirmavam devolutas, em Cubatão e Santos. Na oportunidade, o Administrador teria mandado recolhê-los à Hospedaria de Imigrantes e determinado que o Delegado de Polícia de Santos os atendesse em seu pedido. Mais tarde, um segundo grupo, composto por dez índios guaranis de Faxina, chegou à capital com o objetivo de se reunir ao grupo de Itanhaem, sendo dado a eles o mesmo destino dos anteriores. ${ }^{78}$

$\mathrm{O}$ fato de os índios procurarem as administrações provinciais para solicitar algum tipo de ajuda demonstrava o fracasso do "Serviço de Catequese e Civilização". O Presidente da Província do Pará, Tristão de Alencar Araripe, afirmou que, durante sua administração, fornecera ferramentas de trabalho, roupas e víveres para que um grupo de índios Tucháuas distribuísse em suas aldeias. ${ }^{79}$ Todavia, seu sucessor, João Antônio d'Araujo Freitas Henrique, censurou este tipo de atitude, declarando que em sua administração não distribuíra presentes para nenhum índio, pois despesas deste tipo

\footnotetext{
${ }^{76}$ São Paulo. Relatorio apresentado á Assembléa Legislativa Provincial de S. Paulo pelo Presidente da Província Laurindo Abelardo de Brito no dia 13 de janeiro de 1881. Santos: Typ. do Diário de Santos, 1881. p.39 a p.40.

${ }^{77}$ Pará. Falla dirigida a Assembléa Legislativa Provincial de S. Paulo na abertura da $1^{a}$ Sessão da $25^{a}$ legislatura Em 16 de janeiro de 1884 pelo Presidente Barão de Guajará. S. Paulo: Typ. da "Gazeta Liberal", 1884. p.86.

${ }^{78}$ São Paulo. Falla dirigida a Assembléa Legislativa Provincial de S. Paulo na abertura da $2^{a}$ sessão da $24^{a}$ Legislatura em 10 de janeiro de 1883 pelo Presidente Conselheiro Francisco de Carvalho Soares Brandão. S. Paulo: Typ. do "Ypiranga", 1883. p.60 a p.61.

${ }_{79}$ Pará. Falla com que o exm. sr. conselheiro Tristão de Alencar Araripe, Presidente da Provincia do Pará, abriu a 1.a sessão da 25.a legislatura da Assembléa Provincial no dia 25 de março de 1886. Belem, Typ. do "Diario de Noticias," 1886. p. 57.
} 
eram atribuições do Governo Imperial. ${ }^{80}$ Francisco José Cardoso Junior, um dos últimos administradores do Pará antes da queda da Monarquia, também não tomou nenhuma medida em relação à catequese e civilização dos índios, alegando falta de recursos. $\mathrm{O}$ comércio, segundo ele, embora fosse contrário às "sãs doutrinas do cristianismo", desempenhava aquela missão, quando os regatões buscavam junto às tribos os produtos naturais que elas coletavam. ${ }^{81}$ Mais uma vez, portanto, reconhecia-se o fracasso da política indigenista do Estado.

O final da década de 1870 parece ter sido um momento particularmente crítico no que se refere ao "Serviço de Catequese e Civilização" dos índios, tanto no Pará como em São Paulo. Em 1880, Laurindo Abelardo de Brito afirmou que, apesar da sua importância, aquele ramo do serviço público estava praticamente liquidado em São Paulo. A relevância do serviço, contudo, na opinião do Administrador, consistia em civilizar o índio e, desse modo, aproveitar a sua força de trabalho. Haveria, àquela altura, apenas dois aldeamentos - o Itarery e o S. João Baptista do Rio-Verde - mas de existência "apenas nominal". Muitos índios Chavantes e Coroados vagavam, segundo ele, entre os rios Tieté e Paranapanema, atacando e matando lavradores que tentavam se estabelecer na região. O Presidente da Província recomendou que ali fosse estabelecida uma "colônia bem organizada" para beneficiar índios e lavradores. Não esclareceu, porém, em que moldes seria estabelecida a colônia e como ela poderia ajudá-los. ${ }^{82}$

As alusões dos Presidentes da Província sobre a decadência do "Serviço de Catequese e Civilização", no Pará, coincidiram com a chegada de uma grande leva de migrantes nordestinos na Província. Esta situação pode ter levado os administradores a acreditarem que o problema de braços estivesse próximo de uma solução, diminuindo, conseqüentemente, seu interesse pelo aproveitamento da mão-de-obra indígena na agricultura. Outra possibilidade é que os já escassos recursos da Administração Provincial estavam sendo utilizados para socorrer preferencialmente os flagelados da

\footnotetext{
${ }^{80}$ Pará. Relatorio com que o exm. Snr. Conselheiro João Antonio d'Araujo Freitas Henriques passou a administração da província do Pará ao exm. Snr. Desembargador Joaquim Costa Barradas em 6 de outubro de 1886. Belém: Typ. da República, 1891. p. 83.

${ }^{81}$ Pará. Relatorio com que o exm. snr. conselheiro Francisco José Cardoso Junior, 1.o Vice-Presidente, passou a administração da Provincia, no dia 6 de maio de 1888 ao exm. snr. dr. Miguel J. de Almeida Pernambuco, nomeado por carta imperial de 24 de março ultimo. Pará, Typ. do "Diario de Noticias", 1888. p. 16.

${ }^{82}$ São Paulo. Relatorio apresentado a Assembléa Legislativa Provincial de S. Paulo pelo Presidente da Província Laurindo Abelardo de Brito no dia 5 de fevereiro de 1880. Santos: Typ.do Diário de Santos, 1880. p.172.
} 
seca, que lotavam hospitais, e aumentavam os gastos com segurança, transporte e alimentação.

Em 1883, exatamente quando a situação no Ceará dava sinais de melhora e a emigração para o Vale Amazônico diminuía, um Administrador do Pará voltou a discutir as possibilidades de utilização dos índios, afirmando que seria de grande utilidade para o "grêmio da civilização" atrair os "silvícolas" que vagavam pelas florestas, pondo em sobressalto os habitantes dos povoados. Mas para tanto, seria necessário, segundo ele, um "sistema metódico de catequese", pois o sistema até então adotado não compensara os recursos investidos. ${ }^{83}$ A opinião deste Presidente denota que a preocupação com o índio só existia quando este se tornava um problema - colocava em risco a vida dos moradores de vilas e fazendas - ou quando podia se tornar uma solução de emergência para o problema do suprimento de braços para a agricultura. É possível, também, que o abandono do "Serviço de Catequese e Civilização" por uma ou mais administrações criasse problemas para as futuras, explicando, assim, porque, depois de algum tempo em silêncio, os administradores retomavam o assunto com algum interesse.

Mais tarde, o mesmo Presidente insistiu no problema, assinalando que muitos diretores parciais sequer sabiam o número de tribos sob seu comando e que a falta de comunicação entre os aldeamentos e os centros comerciais da Província impediam que a civilização penetrasse, enfim, a "taba do gentio". Naquela oportunidade, um missionário foi afastado do serviço por ter abandonado seu posto, para se dedicar ao comércio, e mudar a sede do aldeamento. ${ }^{84}$

A discussão continuava girando em torno dos chamados "três agentes de civilização": o missionário, o diretor e o regatão. João Lourenço Paes de Souza, por exemplo, defendia a transformação do índio em "criatura inofensiva" e "agente de produção". Para isso seria necessário cuidar da sua educação desde criança, o que significava contar com a ajuda dos missionários, pois era preciso, segundo ele, falar ao coração e à imaginação do catequizado. Nesse sentido, o Presidente da Província fez

\footnotetext{
${ }^{83}$ Pará. Falla com que o exm. sr. General Barão de Maracajú abriu a 2.a sessão da 23.a legislatura da Assembléa Legislativa da Provincia do Pará em 15 de fevereiro de 1883. Pará: Typ. do Jornal da Tarde, 1883. p. 69-70.

${ }^{84}$ Pará. Falla com que o exm. sr. General Visconde de Maracajú Presidente da Provincia do Pará, pretendia abrir a sessão extraordinaria da respectiva Assembléa no dia 7 de janeiro de 1884. Belém: Typ. do Diario de Noticias, 1884. p. 57-61.
} 
elogios à idéia do bispo Antônio de Macedo Costa, que planejava construir uma "igreja flutuante", ou seja, um barco chamado Christophoro, para levar a fé católica, a moral e a civilização aos lugares mais distantes da Província. ${ }^{85}$

Já o Presidente Tristão de Alencar Araripe acreditava que era possível integrar o índio ao "grêmio dos civilizados", mas admitia a catequese religiosa apenas como forma de retirá-lo das selvas. Sua proposta era que fossem criados estabelecimentos industriais e escolas de artes e ofícios, a exemplo do Instituto Industrial e Agrícola Providência, que fora fundado pelo mesmo bispo, em Belém, para crianças órfãs. Estes estabelecimentos, de acordo com o Administrador, contribuiriam para fixar o índio na "civilização". Deixá-los nos aldeamentos, entregues à direção de catequizadores, era perder tempo e dinheiro, pois acabavam retornando para a floresta. ${ }^{86}$

De acordo com Manuela Carneiro da Cunha, durante o século XIX foi produzida uma extensa legislação indigenista, pois os presidentes de província e o Governo Imperial legislavam cumulativamente e praticamente caso a caso. ${ }^{87}$ Isto não impediu, contudo, que fossem praticadas várias formas de violência contra o índio. Em 1829, um oficial da marinha inglesa teria dito que, nas partes remotas do Pará, a força fazia o direito, enquanto que o poder e o interesse cuidavam da administração prática da lei, muito mais do que a justiça. Com isso, o imperador promulgava leis e os presidentes ordens, mas o branco isolado era ele próprio um imperador, muito mais absoluto do que D. Pedro I no Rio de Janeiro. ${ }^{88}$

Manuela Carneiro da Cunha argumentou, ainda, que a "questão indígena", no século XIX, deixou de ser uma questão de mão-de-obra, para se converter essencialmente numa questão de terras. Mas a autora reconhece variações regionais: na Amazônia, onde a falta de capitais não permitia a importação de escravos africanos, o trabalho indígena continuou sendo fundamental, principalmente no final do oitocentos,

\footnotetext{
${ }^{85}$ Pará. Relatorio que ao exm. sr. dr. João Lourenço Paes de Souza, $1^{o}$. Vice-Presidente da provincia do Gram-Pará, apresentou o exm. sr. dr. Carlos Augusto de Carvalho ao passar-lhe a administração em 16 de setembro de 1885. Pará, Typ. de Francisco de Costa Junior, 1885. p. 112.

${ }^{86}$ Pará. Falla com que o exm. sr. conselheiro Tristão de Alencar Araripe, Presidente da Provincia do Pará, abriu a $1^{a}$ sessão da $25^{a}$ legislatura da Assembléa Provincial no dia 25 de março de 1886. Belem, Typ. do "Diario de Noticias," 1886. p. 57.

${ }^{87}$ CUNHA, Manuela Carneiro da (org.). Legislação indigenista no século XIX. São Paulo: Edusp; Comissão Pró-Índio de São Paulo, 1992. p. 3.

${ }^{88}$ H. L. Maw apud Ibidem. p. 2.
} 
com a exploração da borracha. ${ }^{89}$ A finalidade dos aldeamentos seria, então, a de controlar os índios ditos "bravios" para "desinfestar" o sertão; nas áreas de ocupação antiga, tentava-se, ao contrário, extinguir os aldeamentos para liberar estas terras aos interessados. Outra característica do século XIX seria o estreitamento da arena política pela redução do número de atores e, conseqüentemente de projetos divergentes. Os capuchinhos italianos, por exemplo, introduzidos na década de 1840, eram meros funcionários do Estado, dispersos e isolados.

De fato, em São Paulo, ao contrário do que se dava no Pará, os administradores não pareciam estar divididos entre a ação dos diretores, missionários e comerciantes. Além disso, os pedidos para que os antigos aldeamentos fossem extintos eram insistentemente reiterados, geralmente acompanhados do argumento de que estavam praticamente abandonados e de que era preciso criar novos aldeamentos em áreas "infestadas" de índios "bravios". A análise dos relatórios e falas dos presidentes de província também indica uma relação entre a preocupação em controlar a população indígena destas regiões e a questão da terra, mais especificamente com a instalação de colonos e imigrantes europeus. Nesse sentido, a instalação de aldeamentos e sua manutenção não visavam, propriamente, a criar uma reserva potencial de mão-de-obra, mas apaziguar conflitos, evitar prejuízos materiais e humanos e, sobretudo, confinar os índios numa área especifica e liberar espaços para a agricultura.

Em 1868, Joaquim Saldanha Marinho ${ }^{90}$ afirmou que o Ato Adicional de 1834, no $\$ 5^{\circ}$. do Art. 11, determinara que caberia às Assembléias Provinciais, "cumulativamente" com a Assembléia Geral e Governo Geral, o encargo da despesa com a catequese e civilização dos indígenas. Na verdade, segundo ele, a despesa cabia apenas ao Tesouro Nacional, pois o Conselho de Estado determinara que, havendo faculdade ou jurisdição cumulativa entre duas ou mais autoridades, a competência era daquela que primeiro providenciava com exclusão das outras. Tanto assim que as

\footnotetext{
${ }^{89}$ Ibidem. p. 4. A autora não explorou a questão, mas é sabido que os escravos africanos não eram utilizados na extração do látex. Contudo, a expansão dos negócios da borracha gerava postos de trabalho paralelos e absorvia parte significativa da mão-de-obra livre.

${ }^{90}$ São Paulo. Relatorio apresentado á Assembléa Legislativa Provincial de São Paulo na primeira sessão da décima oitava legislatura no dia 2 de fevereiro de 1868 pelo Presidente da Província o conselheiro Joaquim Saldanha Marinho. São Paulo: Typographia do Ypiranga, 1868.
} 
assembléias provinciais não podiam alterar os regulamentos gerais nem estabelecer novas despesas ou dar novas atribuições. ${ }^{91}$

No ano seguinte, o Senador e Presidente da Província, Barão de Itauna, afirmou que era difícil prestar informações sobre o "Serviço de Catequese e Civilização" dos índios porque as fornecidas pelo Diretor Geral dos Índios eram incompletas. Este, por sua vez, culpava os diretores, que, residindo em lugares distantes dos aldeamentos ou não dando importância a tal serviço, poucas informações prestavam. $^{92}$ Isso explicava, em parte, as constantes substituições de diretores parciais, como fez naquela oportunidade o Diretor Geral, nomeando novo diretor para o aldeamento Itarery, em Iguape, onde se dizia que os índios resistiam à instalação de colonos norte-americanos em terras cedidas pelo governo naquele município.

A resistência indígena em Iguape estaria relacionada com a fixação dos limites entre o território do aldeamento e da colônia de imigrantes. Além de conciliar as duas partes, o novo diretor teria distribuído aos índios ferramentas, peças de vestuário e ajuda pecuniária aos mais necessitados. Quanto ao aldeamento São João Baptista, em Itapeva da Faxina, cujo diretor residia a mais de 12 léguas de distância, não havia informações além da nomeação de um capelão, que solicitou a construção de uma capela e a distribuição de "instrumentos aratórios" e roupas. Outro aldeamento situado em Itapeva da Faxina, o Tijuco-Preto, também apresentava problemas, mas devido à falta de terras para o trabalho. Para agravar o problema, o capuchinho frei José de Loro, que estava encarregado da direção e capelania do aldeamento, fora chamado à Corte e de lá transferido para a Província do Paraná. Sendo assim, o aldeamento não possuía, naquela ocasião, nem diretor nem capelão.

Quanto aos aldeamentos Pinheiros, Mboy, Carapucuhyba, Baruery, S. Miguel, Escada, Itaquaquecetuba e Queluz, o Presidente afirmou que devido o seu estado precário sequer mereciam ser chamados de aldeamentos. Nestes locais, segundo ele, o “tipo americano primitivo" não existia mais em virtude da miscigenação. Além disso, não falavam mais a língua original, a "cultura intelectual" estava totalmente nula e o pessoal vivia disperso e ocioso. Em razão disso, a “indústria agrícola” destes

\footnotetext{
${ }^{91}$ Ibidem. p. 73-74.

${ }^{92}$ São Paulo. Relatorio com que S. Exc. O Sr. Senador Barão de Itauna passou a administração da Província ao Exm. Sr. Commendador Antônio Joaquim da Rosa, $3^{o}$. Vice-Presidente. São Paulo: Typographia Americana, 1869.
} 
aldeamentos era improdutiva e seus terrenos estavam sendo progressivamente invadidos. As informações existentes na secretaria da Província davam conta de que no aldeamento Itarery havia 31 índios; no Tijuco-Preto, 75; no Pinheiro, 43; no Escada, 48; no Queluz, 66; no Mboy, 87; no S. Miguel, 103, no Itaquaquecetuba, 147. Quando aos aldeamento Barurey, São João Baptista e Carapucuhyba sequer havia informações sobre o número de índios que lá viviam. ${ }^{93}$

O Diretor Geral dos Índios, cujo relatório o Barão de Itauna anexou ao seu, ${ }^{94}$ afirmou que era "incrível" a morosidade, senão "culpável negligência" de muitos diretores de aldeamentos no cumprimento de seus deveres. Com exceção do frei José de Loro, todos residiam em lugares distantes dos aldeamentos, resultando disso uma completa ignorância ou indiferença sobre o que lá se passava. Esta situação levou o diretor geral a argumentar que o "Serviço de Catequese e Civilização dos índios" deveria ser realizado por religiosos conscientes de sua missão "evangélica e civilizadora", pois muitos deles eram insensíveis ao sentimento evangélico e colocavam em primeiro plano comodidades pessoais, deixando de lado o filantropismo.

Antonio Candido da Rocha confirmou que dos onze aldeamentos existentes na Província, oito eram "puramente nominais", ou seja, os índios que os compunham haviam sido "incorporados à massa da população" dos diversos municípios a que pertenciam e seus terrenos, "invadidos e usurpados pela prepotência e imoralidade". ${ }^{95}$ Além disso, tais "fragmentos indígenas" não progrediam em gênero algum de indústria, com exceção de uma "acanhada e mal dirigida cultura". Portanto, apenas os aldeamentos São João Baptista, no município da Faxina, Itarery, em Iguape, e São Sebastião do Tijuco-Preto, em Botucatu, podiam ser considerados como tais. ${ }^{96}$

Contudo, Antonio Cândido da Rocha considerava imprescindíveis a presença e atuação de missionários nos aldeamentos para a "regeneração social" dos índios. Esta ênfase se devia, em grande parte, ao ocorrido no aldeamento Tijuco-Preto, cujos

\footnotetext{
${ }^{93} \mathrm{Ibidem}$. p. $27-28$.

${ }^{94}$ Francisco Antônio de Oliveira. Relatorio dos diversos aldeamentos de índios. In: São Paulo. Relatorio com que S. Exc. O Sr. Senador Barão de Itauna passou a administração da província ao Exm. Sr. Commendador Antônio Joaquim da Rosa, $3^{o}$ Vice-Presidente. São Paulo: Typographia Americana, 1869. Anexo no. 20, p. 1-4.

${ }_{95}$ O Presidente apresentou um resumo do Relatório do Diretor Geral dos Índios, Francisco Antonio de Oliveira, datado de 31 de dezembro de 1869, o qual anexou ao seu Relatório. Ver: São Paulo. Relatorio apresentado Á Assembléa Legilstaiva Provincial de São Paulo pelo Presidente da Província o Exm. Sr. Dr. Antonio Candido da Rocha no dia 2 de fevereiro de 1870. São Paulo: Typographia Americana, 1870.

${ }^{96}$ Ibidem. p. 36.
} 
indígenas, de acordo com o Diretor Geral, haviam abandonado o local após a transferência do capelão, frei José de Loro, para a Província do Paraná, e o assassinato do cacique Luiz Lucas. Em 1871, o Relatório do Presidente da Província informava que não se sabia o destino dos índios que haviam abandonado o aldeamento. ${ }^{97}$ Três anos mais tarde, aproximadamente, outro Diretor Geral, Luiz Joaquim de Castro Carneiro Leão, ${ }^{98}$ concluiu que o aldeamento São Sebastião do Tijuco-Preto não tinha como ser mantido e recomendou a sua integração ao aldeamento São João Baptista. O Diretor chamou a atenção também para os índios que "infestavam" os sertões de Botucatu, habitando a margem esquerda do Tieté e a Serra dos Agudos. De acordo com ele não havia esperança de constituir uma catequese regular naquele local devido à falta de missionários para o "serviço da catequese e civilização dos índios" e condições para o estabelecimento de instrução, agricultura e fábricas. Somente a abertura de estradas e a colonização civilizariam aquela região.

Em 1875, o Presidente João Teodoro Xavier incluiu o aldeamento São Sebastião do Tijuco-Preto entre os chamados "nominais", afirmando que apenas o São João Baptista e o Itarery podiam ser de fato considerados como aldeamentos. ${ }^{99}$ A partir daquele ano, os presidentes de província passaram a noticiar com certa regularidade a chegada de índios à capital da Província com o objetivo de solicitar auxílio das autoridades. Segundo João Theodoro Xavier, dez índios guaranis, do Tijuco-Preto, o haviam procurado. O Presidente afirmou que lhes fornecera instrumentos de lavoura e "mais alguns objetos que necessitavam". Em seguida, outros quatorze indígenas do aldeamento São João Baptista teriam procurado o Diretor Geral e solicitado roupas e outros utensílios.

De 1875 a 1880, os presidentes que administraram a Província de São Paulo praticamente ignoraram o "Serviço de Catequese e Civilização dos índios". Não deve ser coincidência o fato de o assunto voltar a merecer a atenção daqueles que governaram a Província na década de 1880. Logo nos primeiros dias do ano de 1881 os deputados

\footnotetext{
${ }^{97}$ São Paulo. Relatorio apresentado á Assembléa Legislativa Provincial de São Paulo pelo Presidente da Província, o Exm. Sr. Dr. Antonio da Costa Pinto Silva no dia 5 de Fevereiro de 1871. São Paulo: Typographia Americana, 1871.

${ }^{98}$ São Paulo. Relatorio apresentado á Assembléa Legislativa Provincial de S. Paulo pelo Presidente da Província, o Exm. Sr. Dr. João Theodoro Xavier, em 5 de fevereiro de 1874. São Paulo: Typographia Americana, 1874. Anexo 27, p. 215-216.

${ }^{99}$ São Paulo. Relatorio apresentado á Assembléa Legislativa Provincial de S. Paulo pelo Exm. Sr. Dr. João Theodoro Xavier, Presidente da Província, no dia 14 de fevereiro de 1875. São Paulo: Typographia do Diario, 1875. p. 100.
} 
provinciais criaram uma taxa que praticamente proibia a entrada de escravos em São Paulo, medida esta que, combinada com o aumento da pressão abolicionista, ${ }^{100}$ exigia a busca urgente de fontes alternativas de suprimento de mão-de-obra.

De acordo com Laurindo Abelardo de Brito, o "Serviço de Catequese e Civilização dos índios" estava quase "suprimido" na Província, apesar de sua importância em termos de aproveitamento da força de trabalho dos índios. Existiriam, em 1880, apenas dois aldeamentos nominais na Província: o Itarery e o São João Baptista do Rio Verde. Entretanto, muitos índios Chavantes e Coroados vagavam entre os rios Tieté e Paranapanema, o que resultava em ataques e mortes de lavradores que tentavam se estabelecer na região. De acordo com o Administrador, a instalação de uma "colônia bem organizada" naquela área seria um "importante benefício" para índios e agricultores que lá residiam. ${ }^{101}$

Alguns meses depois, Laurindo Abelardo de Brito afirmou que a catequese era o mais humanitário e profícuo meio de "chamar ao trabalho e à civilização" milhares de "entes humanos", que habitavam as matas e se assemelhavam às feras, "privados da luz do ensino e da influência das lições do Evangelho". Todavia, o Administrador reconhecia que o estado dos aldeamentos continuava precário. O São João Baptista, no município do Rio Verde, por exemplo, teria apenas sessenta índios, enquanto o Itarery, no município de Iguape, somente dez. Nos demais haveria menos do que este contingente. Em razão disso, e atendendo a um pedido do Diretor Geral dos índios, o Presidente da Província solicitou à Assembléia Provincial que extinguisse os aldeamentos "puramente nominais", e criasse três novos, nos municípios de Faxina, Botucatú e Lençóis. Além disso, pediu que contratasse o capuchinho Frei Timótheo de Castel Nuevo, diretor da Colônia Indígena de S. Pedro de Alcântara, no Paraná, para

\footnotetext{
100 O termo "pressão abolicionista" é usado aqui para designar não só o conhecido movimento desencadeado pelos abolicionistas, a partir de 1879, mas também outros elementos, cuja combinação surtiu um efeito politicamente explosivo sobre a escravidão, tais como as várias formas de protesto dos escravos e a crescente conscientização nos principais centros de cultura do mundo e no país de que a escravidão era uma instituição em completo antagonismo com a sensibilidade moral da época.

${ }^{101}$ São Paulo. Relatorio apresentado á Assembléa Legislativa Provincial de S. Paulo pelo Presidente da Província Laurindo Abelardo de Brito no dia 5 de fevereiro de 1880. São Paulo: Typ. á vapor do Diario de Santos, 1880. p. 172.
} 
"reduzir" um grupo de índios Coroados que estariam promovendo depredações e morte na região do rio Paranapanema. ${ }^{102}$

O Conde de Três Rios foi ainda mais enfático nas críticas ao "Serviço de Catequese e Civilização dos índios" da Província. Segundo ele, o assunto havia “descaído da atenção dos poderes públicos”, apesar do seu caráter humanitário. Em algumas regiões, índios "quase inofensivos" vagavam nas proximidades dos povoados, necessitando de ajuda para sobreviver; em outras, a catequese era medida de segurança, uma vez que as incursões deles em povoados e fazendas eram freqüentes, causando prejuízos e sobressaltos na população. Todavia, o Presidente não cogitava outra forma de lidar com o problema além da criação de novos aldeamentos. Nesse sentido, propôs à Assembléia Provincial esta medida para conter os selvagens e atrair os índios mansos, como sucedia em Campos Novos, onde "hordas de inimigos" estavam entre a "população civilizada".

A finalidade da catequese era, portanto, tornar úteis à sociedade homens que viviam na ociosidade e garantir a segurança pessoal dos habitantes de lugares ameaçados pelos índios, como Santa Cruz do Rio Pardo, S. Pedro do Turvo, Capella de Campos Novos e Lençóes. A "paz armada" em que viviam os habitantes e o espírito de hostilidade dos indígenas, tornava inconciliável o "interesse criado" de uns com o dever da catequese em favor de outros. Nesse sentido, o Presidente solicitou à Assembléia Provincial que destinasse uma verba para que a Administração Provincial pudesse contratar o serviço de missionários. Tratava-se, em última instância, de levar aos pontos mais remotos a "ação benéfica dos poderes públicos" e de aproveitar "todas as forças vivas da nação." 103

A política de aldeamentos, que, conforme assinalamos, começou a ser adotada no século XVI pelos jesuítas, ${ }^{104}$ foi modificada a partir da expulsão da Companhia. Se antes a administração ficava a cargo dos missionários, a partir de então começou a ser desempenhada por leigos nomeados pelo Governo. No século XIX, contudo, os

\footnotetext{
${ }^{102}$ São Paulo. Relatorio apresentado á Assembléa Legislativa Provincial de S. Paulo pelo Presidente da Província Laurindo Abelardo de Brito no dia 13 de janeiro de 1881. Santos: Typ. do Diario de Santos, 1881. p.39 a p.40 Catechese.

${ }^{103}$ São Paulo. Relatorio dirigido á Assembléa Legislativa Provincial de S. Paulo pelo $1^{o}$. Vice-Presidente da Província Conde de Três-Rios e apresentado no acto da installação da mesma Assembléa pelo $4^{o}$. Vice-Presidente Dr. Manoel Marcondes de Moura e Costa. Santos: Typ. a vapor do Diario de Santos, 1882. p.58.

${ }^{104}$ CUNHA, Manuela Carneiro da (org.). Op. cit., p. 18.
} 
missionários voltaram a participar da administração, mas como subordinados dos administradores leigos. Nesse período, os aldeamentos passam a cumprir outras funções. A concentração dos índios em uma determinada área - além de criar exércitos potenciais de mão-de-obra em lugares estratégicos, ou seja, nas proximidades de vilas, cidades, rotas fluviais e terrestres, estabelecimentos agrícolas, "industriais" e militares proporcionava também a liberação de extensas áreas ocupadas pelos índios para que fazendeiros, migrantes e imigrantes desenvolvessem a agricultura e a pecuária. Além disso, era uma forma de distinguir os índios considerados "domésticos" ou "mansos" dos "bravios", o que evitava violências.

Assim, em 1883, por exemplo, o conselheiro Francisco de Carvalho Soares Brandão afirmou que vagava pelos campos de Capivari, adiante de S. José dos Campos Novos, um grupo de índios Chavantes. ${ }^{105}$ No ano seguinte, o Barão de Guajará, Domingos Antônio Rayol, afirmou que era necessário aldeá-los, suprindo-os do necessário para que pudessem se estabelecer em lugar determinado e se dedicar à lavoura. Nesse sentido, teria nomeado, por sugestão do Diretor Geral dos Índios, um diretor exclusivamente para cuidar do novo aldeamento. ${ }^{106} \mathrm{O}$ caso demonstra não apenas uma continuidade administrativa como também a existência de uma escala hierárquica que devia ser cumprida e respeitada, pois o Presidente nomeara um funcionário indicado por seu subalterno imediato, que ao contrário dele permanecia no seu posto por vários anos.

Em meados da década de 1880, havia onze aldeamentos na Província, mas apenas três eram considerados como tais: o Rio Verde, com 302 índios (163 do sexo masculino e 137 do sexo feminino); o Itarery, com 57 índios (29 do sexo masculino e 28 do sexo feminino); e o Tijuco Preto, com 21 índios (9 do sexo masculino e 12 do sexo feminino). Todos estes índios estavam batizados, mas nenhum sabia ler nem escrever. $\mathrm{O}$ aldeamento São João Batista do Rio Verde seria o mais procurado devido à riqueza de suas terras. Entretanto, não havia casas suficientes no local, nem escolas e professores, muito menos um capelão. A situação era semelhante em Itarery, pois as terras eram

\footnotetext{
${ }^{105}$ São Paulo. Falla dirigida a Assembléa Legislativa Provincial de S. Paulo na abertura da $2^{a}$ sessão da $24^{a}$ Legislatura em 10 de janeiro de 1883 pelo Presidente Conselheiro Francisco de Carvalho Soares Brandão. S. Paulo: Typ. do Ypiranga, 1883. p.60 a p.61 Catechese e Civilisação dos Índios.

${ }^{106}$ São Paulo. Falla dirigida a Assembléa Legislativa Provincial de S. Paulo na abertura da $1^{a}$ Sessão da $25^{a}$ legislatura Em 16 de janeiro de 1884 pelo Presidente Barão de Guajará. S. Paulo: Typ. da Gazeta Liberal, 1884. p. 86.
} 
boas, embora faltassem professor e capelão. Já o Tijuco Preto, antes denominado Piraju, voltara a ser procurado pelos índios depois de ter sido abandonado.

Os administradores chamavam de nominais os aldeamentos em estado de abandono ou que haviam perdido a característica original. Estavam nessa situação, nas décadas de 1870 e 1880, o São Miguel, Pinheiros, Baureri e Carapicuíba, no município da capital; Itaquaquecetuba e Escada, no município de Mogi das Cruzes; Mboi, no município de Santo Amaro, e Queluz, então cidade e sede de comarca do mesmo nome. Alguns destes haviam sido elevados à categoria de freguesia e outros à de vila. Já o de Queluz fora a elevado à de cidade, pois os "antigos índios" haviam se "confundido" com a "população civilizada".

De acordo com José Luiz de Almeida Couto, o Diretor Geral dos Índios de São Paulo, Brigadeiro Luiz de Castro Carneiro Leão, assinalara em Relatório que poucos serviços podia prestar devido à falta de pessoal e de recursos em sua repartição, mas recomendara a criação de um aldeamento em São José dos Campos Novos, na comarca de Lençóis, para civilizar os índios Xavantes. Estes, além de numerosos, seriam de natureza pacífica e trabalhadores, o que exigiria poucos gastos para torná-los "úteis à sociedade". ${ }^{107}$ Assim, a função do diretor geral ia além de indicar funcionários para serem nomeados.

A análise dos relatórios indica que o "Serviço de Catequese e Civilização" estava muito mais sob responsabilidade dos diretores gerais do que propriamente sob a dos presidentes de província. Afinal, a maioria das informações prestadas por estes era extraída dos relatórios dos seus subalternos. Em algumas situações, apenas, os presidentes assumiam riscos e contrariavam até mesmo seus antecessores. Em 1886, por exemplo, João Alfredo Correa de Oliveira, afirmou que os aldeamentos São João Baptista do Rio Verde, Itarery e Tijuco Preto também estavam em decadência. O primeiro, situado no município de Itapeva da Faxina, havia sido fundado em 1845 com índios da tribo dos Cayuás, ocupando o território compreendido entre os rios Verde e Itararé, com 5 a 6 léguas de extensão e 3 de largura. O aldeamento teria prosperado até 1862, quando contava com 80 fogos e 478 índios de ambos os sexos. Em 1871, o número de fogos havia reduzido para 77 e o de habitantes para 306. A partir daí, os

\footnotetext{
${ }^{107}$ São Paulo. Falla dirigida á Assembléa Legislativa Provincial de S. Paulo na abertura da $2^{a}$ Sessão da $26^{a}$ legislatura em 10 de janeiro de 1885 pelo Presidente Dr. José Luiz de Almeida Couto. S. Paulo: Typ. da Gazeta Liberal, 1885. p.97 a p.98.
} 
índios foram abandonando o aldeamento, até que, em 1880, restassem somente sessenta. De 1881 em diante, eles retornaram e o número elevou-se para 306.

De acordo com o Presidente da Província, as causas da decadência eram a falta de missionários e de estabelecimento de educação e instrução. $\mathrm{O}$ aldeamento nunca teria tido uma organização regular para a catequese e civilização, pois os índios haviam se "arranchado" e se dedicado à pequena lavoura por conta própria, nas terras que conseguiam ou que recebiam dos seus antepassados. As terras do patrimônio da aldeia não estariam sendo aproveitadas na sua totalidade pelos poucos indígenas que lá existiam, embora fossem apropriadas ao cultivo do café e outros produtos. Em razão disso, o Presidente recomendou o arrendamento das que os índios não pudessem cultivar ou o estabelecimento de uma colônia agrícola, conforme já teria sido sugerido pela Câmara Municipal local.

Já o aldeamento de Itarery, situado no município de Iguape, havia sido fundado em 1837, em terras cedidas pelo Governo. Apesar das terras serem de boa qualidade, segundo o Administrador, o aldeamento pouco teria prosperado. Em 1871 só haveria ali 12 fogos e 63 índios da tribo Cayuá. Em 1877, a população alcançara 150 índios guaranis, mas teria reduzido para 10 em 1880. Daquele ano até 1886, este número se elevara para apenas 57. João Alfredo Corrêa de Oliveira qualificou de "mesquinho" o trabalho agrícola ali realizado pelos índios, afirmando que não tinham "permanência", nem "atividade". A aldeia não possuía capela, nem escola, nem qualquer oficina de artes mecânicas. Da mesma forma que para o aldeamento Rio Verde, o Presidente sugeriu que os índios continuassem com o usufruto das terras que estavam em sua posse. Quanto às demais, poderiam ser arrendadas ou nelas estabelecido algum núcleo colonial.

Quanto ao aldeamento Tijuco Preto, fundado em 1864 no município de Botucatu, onde haveria muitos "índios errantes", nunca teria tido organização regular, nem prosperidade, apesar de a aldeia encerrar "elementos naturais de progresso". Em razão disso, os índios teriam se dispersado. Havia, em 1886, apenas 21 habitantes. Em relação aos de Pinheiros, Mboy, Carapicuhyba, Baruery, S. Miguel, Escada, Queluz e Itaquaquecetuba, o Presidente da Província recomendou a sua extinção.

Em contrapartida, o Presidente alegou que na comarca de Lençóes, nos Campos Novos do Turvo, cujas terras seriam muito férteis, "erravam" mais de mil 
índios Chavantes e Coroados, em um sertão de mais de 30 léguas. As regiões entre os rios Preto, Paranapanema e Paraná estariam “infestadas por indígenas selvagens”. Nesse sentido, recomendou que fosse ali desenvolvida a catequese. Haveria outras "necessidades imperiosas" para serem atendidas, mas as "circunstâncias financeiras" da Província não teriam permitido que a administração tratasse do serviço como se deveria. $^{108}$

A intensidade das críticas ao serviço de catequese talvez estivesse relacionada com as tentativas do Governo Provincial e geral de criar núcleos coloniais São Paulo. A partir de 1885, quando os conservadores voltaram a constituir gabinetes ministeriais, depois de praticamente sete anos de domínio dos liberais, uma das alternativas pensadas para solucionar a crise da grande lavoura foi a criação de núcleos coloniais em diversas regiões da Província. ${ }^{109}$ A radicalização do movimento abolicionista e a falta de perspectivas em relação às possibilidades de introdução de um contingente significativo de imigrantes, pelo menos até os efeitos da chamada imigração em massa começassem a ser percebidos, fez com que vários presidentes de províncias, deputados provinciais e gerais passassem a apoiar medidas favoráveis à pequena lavoura. Acreditava-se, então, que as grandes propriedades não sobreviveriam sem o braço escravo, vindo a se fragmentar tão logo a abolição final fosse decretada. Assim, a instalação de núcleos coloniais nas áreas ocupadas pelos aldeamentos considerados fracassados e a criação de novos aldeamentos nas áreas "infestadas" por índios seria uma forma de se antecipar um desfecho tido como inevitável.

Se Alfredo Corrêa de Oliveira fora mais incisivo nas suas conclusões sobre a situação dos aldeamentos, o Barão do Parahyba se limitou a dizer que pouco tinha a acrescentar em relação ao "Serviço de Catequese e Civilização dos índios". A única alteração seria a nomeação de diretores para os aldeamentos Baruery e São João Baptista do Rio-Verde. Por outro lado, citando o parecer do Diretor Geral dos Índios, o Presidente reiterou que somente podiam ser considerados como aldeamentos o TijucoPreto, São João Baptista do Rio-Verde e Itarery. Quanto aos demais, recomendava que

\footnotetext{
${ }^{108}$ São Paulo. Relatorio apresentado a Assembléa Legislativa Provincial de São Paulo pelo Presidente da Província João Alfredo Corrêa de Oliveira no dia 15 de fevereiro de 1886. São Paulo: Typ. de Jorge Seckler \& C., 1886. p.41 a p.42.

${ }^{109}$ Esta questão será discutida mais detalhadamente no Capítulo IV.
} 
fossem declarados extintos para os efeitos das leis $\mathrm{n}^{\mathrm{o}}$. 1114 de 27 de setembro de 1860, no. 601 , de 18 de setembro de 1850 e Aviso de 8 de maio de 1878 .

Mesmo os aldeamentos considerados existentes estavam, segundo ele, em estado de decadência. Não havia neles escolas, capelas e oficinas mecânicas. No que se referia à catequese e civilização dos índios, também, tudo estava por fazer. Na região onde deveriam ser fundados novos aldeamentos, mais precisamente em Lençóis, Botucatu e Campos Novos do Turvo, vagavam mais de mil índios Chavantes e Coroados. O frei Timotheo de Castelnovo, diretor de aldeamentos de índios na Província do Paraná, o havia convencido de que era necessário criar aldeamentos na região do rio Paranapanema, próximo à foz do Tibagy. Nesse sentido, contratara o missionário para "estudar bem a questão" e elaborar um relatório minucioso a respeito do assunto, que o Presidente classificava de "obra filantrópica e civilizadora". Só então poderia ser aplicada de forma convenientemente a verba votada pelos deputados para o "Serviço de Catequese e Civilização" dos "infelizes compatriotas nossos e ao bem estar e tranqüilidade das populações civilizadas" que a cada dia invadiam o território até então ocupado pelos índios. ${ }^{110}$

Alguns meses depois, o Visconde do Parnahyba voltou ao assunto, afirmando que as "correrias de índios bravios" estavam se repetindo com grande prejuízo para as propriedades e perdas de "preciosas vidas". Faltavam os recursos necessários para o "serviço da catequese e civilização", razão pela qual ele ainda se encontrava em estado de “embrião”. Os aldeamentos Tijuco Preto, São João Baptista do Rio Verde e Itarery ainda apresentavam uma "aparência de vida", mas os aldeamentos Mboy, Carapucuhyba, Baruery, São Miguel, Escada, Queluz e Itaquaquecetuba só existiam in nomine e deviam ser declarados extintos. Em todo caso, encarregara o engenheiro-chefe da Comissão do Vale do Paranapanema, José Ribeiro da Silva Pirajá, de examinar o local onde devia ser criado o núcleo para a catequese nos campos do Avanhandava, entendendo-se para este fim com o frei Timotheo de Castel-Novo.

Além disso, dando execução à Lei $n^{\circ}$. 68 de 2 de abril daquele ano, nomeara para o "Serviço de Catequese e Civilização dos índios" no vale entre os rios Tieté e Paranapanema, o frei Mariano de Bagnaia e frei Francisco d'Alatri, com a gratificação

\footnotetext{
${ }^{110}$ São Paulo. Relatorio apresentado a Assembléa Legislativa Provincial de São Paulo pelo Presidente da Província Barão do Parnahyba no dia 17 de janeiro de 1887. São Paulo: Typ. de Jorge Seckler \& Comp., 1887. p.27 a p.28.
} 
mensal de 100\$000. A nomeação era provisória, pois cabia ao Governo geral expedir uma provisão definitiva. Os missionários deveriam estabelecer residência na Freguesia de São José dos Campos Novos, que se tornaria sede e centro da catequese naquele vale, da qual dependeriam, na parte religiosa, os outros aldeamentos da região.

Para diretor do aldeamento que seria formado na raiz da Serra dos Agudos, em lugar designado pela Câmara Municipal de S. José dos Campos Novos, fora nomeado o frei Francisco d'Alatri, com residência provisória na mesma localidade até que fosse instalado o aldeamento. Este missionário estava autorizado a fazer as despesas necessárias para o ajuste do pessoal, até o número de seis auxiliares, transporte e abertura de picadas em procura dos índios bravios. Correria por conta da Província o transporte do pessoal e bagagens até o porto de Lençóes, assim como a despesa que se fizesse para o transporte desde este porto até Campos Novos, e a compra de objetos para "brindar os indígenas". O Presidente declarou que iria expedir ordem ao engenheirochefe da medição de terras no Vale do Paranapanema para marcar e alinhar o aldeamento na raiz da serra e autorização para mandar fazer roçados; à Câmara Municipal e outras autoridades da vila de São José de Campos Novos mandaria auxiliar a catequese "no que estivesse ao seu alcance". O superior dos franciscanos teria exigido a criação de um regulamento para o "serviço da catequese e civilização", mas o Presidente da Província declarou que não tivera tempo para concluí-lo, deixando suas bases "assentadas". 111

Francisco de Paula Rodrigues Alves afirmou que seu antecessor, o Barão de Parnahyba, iniciara uma série de "medidas tendentes a regular o "Serviço da Catequese na Província" e que daria continuidade a elas. Nesse sentido, entendera-se o Comissário Geral dos Capuchinhos para o envio de mais missionários - "intrépidos civilizadores" à região do Paranapanema, diante do receio de novos ataques dos índios, pois os jornais publicavam notícias - ainda que não confirmadas - de que ocorria grande mortandade de índios por meios bárbaros naquela região. O Comissário Geral teria prometido mandar mais dois missionários que se incumbissem da "instrução científica e moral" dos indígenas e dos novos trabalhadores ou colonos. As missões, segundo o Presidente

${ }^{111}$ São Paulo. Exposição com que o Exm. Snr. Visconde do Parnahyba passou a administração da província de São Paulo ao Exm. Snr. Dr. Francisco de Paula Rodrigues Alves Presidente desta Província no dia 19 de novembro de 1887. São Paulo: typ. de Jorge Seckler \& Comp., 1888. p.32 a p.34. 
da Província, iriam produzir os efeitos esperados, abrandando o ódio dos "nacionais" contra os "selvagens" e chamando os índios ao "grêmio da civilização". 112

Cada vez mais, portanto, os presidentes pareciam considerar o trabalho dos missionários indispensável. Tanto assim que, tendo o engenheiro José Ribeiro da Silva Pirajá concluído a planta do aldeamento da Serra dos Agudos, o Presidente não autorizou a sua construção porque o missionário frei Mariano ponderara que o aldeamento devia ser estabelecido em local mais afastado. O engenheiro afirmou, então, lastimar a decisão, pois enquanto não fosse estabelecida, por meio de aldeamentos, a catequese regular dos índios, que ainda "infestavam” a zona entre a Serra dos Agudos e o rio Tieté, continuariam sistematicamente por parte deles e da população sertaneja as agressões, verdadeira "luta fratricida" que envergonhava a civilização do país. Da mesma forma, mas na condição de membro da Comissão de Terras do Vale do Paranapanema, José Ribeiro da Silva Pirajá recomendou providências urgentes do Presidente, pois "repetidos fatos de agressões" cometidas por índios estavam se dando no município de Campos. ${ }^{113}$

As divergências entre o engenheiro e o frei talvez fossem indício de uma disputa mais acirrada envolvendo missionários e burocratas sobre a condução do “Serviço de Catequese e Civilização dos índios”. Para a burocracia, o índio se colocava naquele momento como um obstáculo ao acesso à terra por parte de colonos, imigrantes e fazendeiros. Nesse sentido, a política de aldeamento era vista por eles como uma forma de exercer um controle efetivo sobre as os grupos indígenas; já os missionários, provavelmente mais preocupados em exercer seu trabalho espiritual, concebiam a catequese como uma forma de conversão do índio ao cristianismo e não como forma de promover o ingresso dos índios no "grêmio" da civilização como força de trabalho.

Isso explicaria porque o missionário desejava que o aldeamento fosse instalado em local mais afastado, enquanto o engenheiro argumentava que o mesmo devia ficar em lugar mais próximo da "civilização". Aliás, na sua concepção, adiar a instalação do

112 São Paulo. Relatorio com que o Exm. Snr. Dr. Francisco de Paula Rodrigues Alves passou a administração da província de S. Paulo ao Exm. Snr. Dr. Francisco Antonio Dutra Rodrigues $1^{o}$. VicePresidente no dia 27 de abril de 1888. São Paulo: typ. de Jorge Seckler \& Comp., 1888. p.17 a p.18.

${ }^{113}$ Relatorio dos Serviços executados pela Commissão de Terras do Valle do Paranapanema, durante o semestre de julho a dezembro de 1887, apresentado ao Ex. Presidente da Província pelo chefe da mesma Commissão, o Engenheiro José Ribeiro da Silva Pirajá. In: São Paulo. Relatorio com que o Exm. Snr. Dr. Francisco de Paula Rodrigues Alves passou a administração da província de S. Paulo ao Exm. Snr. Dr. Francisco Antonio Dutra Rodrigues $1^{\circ}$. Vice-Presidente no dia 27 de abril de 1888. São Paulo: Typ. de Jorge Seckler \& Comp., 1888. 
aldeamento ou instalá-lo em local mais distante não contribuiria para o povoamento da região e, consequentemente, para o progresso. Nesse sentido, ele lamentou a falta de recursos para o prolongamento da Estrada de Ferro Sorocabana até aquela região. O percurso de $230 \mathrm{~km}$ entre Botucatu e Campos Novos, que seria transposto pela ferrovia, era o que havia de "mais fértil e mais produtivo na Província", devendo atender à "já admirável corrente imigratória" que para lá se dirigia, corrente que tendia a "avolumarse extraordinariamente".

\subsection{Trabalho e progresso}

Segundo Manuela Carneiro da Cunha, ${ }^{114}$ o único documento indigenista geral elaborado durante o regime monárquico foi o Regulamento das Missões, promulgado em 1845. Como seus autores concebiam os aldeamentos apenas como uma forma de transição para a assimilação completa dos índios, a autora afirmou que se tratava muito mais de documento administrativo do que de um plano político. Depois dele, a única inovação seria a experiência do General Couto de Magalhães no Vale do Araguaia, durante a década de 1870, que o governo pretendia estender ao Amazonas e ao Mucuri ou ao rio Doce. Este plano previa a extinção do sistema de aldeamentos e a criação de internatos para crianças indígenas, obtidas em troca de ferramentas, as quais seriam transformadas, no futuro, em intérpretes lingüísticos e culturais para levarem, juntamente com os missionários, a "civilização" aos seus parentes. ${ }^{115}$

Embora Manuela Carneiro da Cunha tenha afirmado que a política adotada no Vale do Araguaia foi abandonada na última década do Império, um texto publicado em 1902 por Domingos Antonio Rayol, o Barão de Marajó, indica que pelo menos alguma coisa do que se praticava ali teria sido aproveitado. ${ }^{116}$ De acordo com o Barão, o regime monárquico havia se empenhado no sentido de promover a catequese com proveito para os indígenas e para os núcleos estabelecidos. Entretanto, as fraudes e as maldades dos

\footnotetext{
${ }^{114}$ CUNHA, Manuela Carneiro da (org.). Op. cit., p. 11.

115 Segundo Mary Karasch, durante a década de 1870, retomou-se a prática jesuítica de catequizar os índios em suas próprias línguas. De acordo com essa concepção, as pessoas mais indicadas para levar "as luzes da civilização" às "tribos selvagens" eram os filhos das famílias aborígenes, educados desde a infância nas idéias, costumes e instituições da sociedade dita civilizada. KARASCH, Mary. Op. cit. p. 405.

${ }^{116}$ BARÃO DE GUAJARÁ. Catechese de índios no Pará. In: Annaes da Bibliotheca e Archivo Publico do Pará. Belém: Imprensa Oficial, 1902. Tomo II. p. 117-183.
} 
“ambiciosos sem coração”, ou seja, diretores e regatões, teriam frustrado as melhores intenções dos governantes e legisladores. ${ }^{117}$

A análise de Domingos Antônio Rayol se baseava, neste aspecto, no relatório do Presidente Jeronimo Francisco Coelho, que administrara o Pará em 1849, e provavelmente na sua própria experiência, pois, como sabemos, ele governou São Paulo em meados da década de 1880. Embora a figura do regatão não estivesse presente nesta última Província, havia várias outras semelhanças entre os serviços de catequese e civilização adotados em ambas as Províncias. Além disso, as críticas de Jeronimo Francisco Coelho não eram muito diferentes daquelas feitas pela maioria dos presidentes que governaram o Pará entre 1868 e 1889.

De acordo com o Barão, um ofício do Bispo dom Antônio de Macedo Costa ao Ministro do Império, Marquês de Olinda, datado de 1865 e publicado no jornal Estrella do Norte, criticando a subordinação dos missionários aos diretores, fizera com que o Governo entregasse a administração das aldeias aos cuidados dos missionários. Porém os problemas continuaram, pois poucos religiosos teriam se deslocado para a Amazônia e, dentre os que lá se estabeleceram, alguns "não se recomendavam por zelo e probidade". ${ }^{118}$

Isto demonstrava, concluiu o Barão, que a catequese, visando o aproveitamento da mão-de-obra indígena, era impraticável. Os agentes do poder público, conscientes disso, passariam, então, a suprir a falta de braços com imigrantes estrangeiros e migrantes brasileiros, "mais afeitos ao trabalho inteligente e regular". ${ }^{119}$ Entretanto, havia muitas terras a serem cultivadas e indústrias para serem desenvolvidas. A população devia aumentar, mas sem que o índio fosse maltratado e perseguido. Nesse sentido, recomendou que, em lugar do sistema adotado, se deixasse ele viver "desassombrado" nas matas, longe de seus "pretensos civilizadores", até que, esquecendo-se dos "seus justos ressentimentos", decidisse buscar a convivência da "gente civilizada". 120

\footnotetext{
${ }^{117}$ Ibidem. p. 165-167.

${ }^{118}$ Ibidem. p. 168-169. O Barão mencionou o caso de um missionário que teria remetido grandes somas de dinheiro para a Europa, explorando o trabalho dos índios na produção de borracha e coleta de produtos extrativos. Quanto à entrega da administração dos aldeamentos aos missionários, ela parece ter se limitado a um curto período, pois a análise dos relatórios indica que a partir de 1868 seriam os diretores parciais os responsáveis pela função.

${ }^{119}$ Ibidem. p. 173.

${ }^{120}$ Ibidem. p. 175.
} 
Outra opção estaria na lei sancionada pelo governador José Paes de Carvalho, autorizando a criação de "centros agrícolas e pastoris", destinados a recolher e educar filhos dos indígenas, desvalidos ou órfãos. ${ }^{121}$ Naqueles locais, dotados de capelas, casas para diretores, escolas, oficinas e moradias particulares, os índios trabalhariam na coleta de produtos naturais e em plantações de mandioca, milho, arroz, cana, feijão, café e cacau. ${ }^{122}$ Interessados em participar da iniciativa, um grupo de missionários religiosos teriam fundado em Belém uma associação dedicada à catequese.

Os "centros agrícolas e pastoris" a que se referia o Barão de Marajó foram provavelmente inspirados na política indigenista desenvolvida pelo General Couto de Magalhães no Vale do Araguaia. As semelhanças são evidentes, afinal os "centros" destinavam-se a recolher e educar jovens de 8 a 16 anos, provavelmente com o objetivo de utilizá-los, conforme assinalou Mary Karasch, como intérpretes lingüísticos e culturais na "civilização" dos seus parentes adultos. Porém, como a referida lei tornava o ensino agrícola e pastoril obrigatório nos "centros", podia-se também aproveitá-los como mão-de-obra ou transformá-los em pequenos agricultores. Segundo Ernesto Cruz um missionário da Ordem dos Capuchinhos Lombardos, talvez pertencente ao grupo ao qual se referiu o Barão de Marajó, tomou a iniciativa de fundar um núcleo nas condições previstas pela lei, que em 1900 abrigava não apenas indígenas mas também imigrantes. $^{123}$

De acordo com o Barão de Marajó, a pátria necessitava de braços, não podendo, portanto, "dispensar os serviços de todos os seus filhos na concorrência pacífica e espontânea dos auxiliares estrangeiros”. Devia-se chamá-los, mas era “dever imperioso" tratá-los melhor do que se havia feito até então. Os índios mereciam benevolência e seriam úteis, embora seu serviço fosse "insuficiente, fraco, irregular e rude", não

${ }^{121}$ O General José Vieira Couto de Magalhães, nascido em Diamantina (MG), cursou a Faculdade de Direito de São Paulo num momento em que o movimento indianista vivia o seu auge. Data daí, talvez, seu interesse pela questão indigenista. Presidiu as províncias do Pará, Mato Grosso e Goiás, sendo também eleito deputado por mais de uma vez. Quando administrou a Província de Goiás teria elaborado um projeto de navegação dos rios Araguaia e Tocantins, ocasião em que percorreu a região e se envolveu em várias outras iniciativas de povoamento do sertão. Na década de 1870 , já Brigadeiro, foi nomeado diretor da catequese na região do Araguaia, sendo uma de suas tarefas distribuir ferramentas aos índios e pagar os missionários.

${ }^{122}$ BARÃO DE GUAJARÁ. Catechese de índios no Pará. Op. cit. p. 175-176. Os aldeamentos a que se referia o Barão era os de Maracanan e Araguaya, o que nos leva a crer que se tratasse do sistema que, segundo Manuela Carneiro da Cunha, fora adotado por Couto Magalhães na década de 1870.

${ }^{123}$ Existiriam no núcleo 271 indígenas e 113 imigrantes. CRUZ, Ernesto. Colonização do Pará. Belém: Instituto de Pesquisas da Amazônia, 1958. p.129-132. 
suprindo, portanto, as necessidades do país. Nas condições em que ele se encontrava, necessitava de "outros elementos de vida, mais numerosos, mais produtivos, mais enérgicos e capazes de acelerar a prosperidade do nosso solo, "tão vasto como despovoado, tão desconhecido como nulo para a indústria". ${ }^{124}$

Entretanto, como observou Mary Karasch, o Governo Imperial destinava escassos recursos para o "Serviço de Catequese e Civilização dos índios". Em termos de política indigenista, limitavam-se a adotar programas do século XVIII de aldeamento e pacificação com o objetivo de transformar os índios em trabalhadores úteis, que pudessem sustentar a si mesmos e à "sociedade civilizada" através da agricultura e do comércio fluvial. ${ }^{125}$ Havia por parte dos governantes a preocupação em evitar que os índios se transformassem em obstáculo ao processo de ocupação do sertão. Isso é muito mais evidente em São Paulo do que no Pará, provavelmente pelo fato de o povoamento daquela Província estar em fase mais adiantada do que nesta.

Outro aspecto evidenciado pelos relatórios e falas é a dependência dos governos provinciais em relação aos missionários e, ao mesmo tempo, o papel limitado que estes desempenhavam pelo fato de estarem subordinados ao Governo. A posição dos presidentes era ambígua: pretendiam instituir uma administração leiga nas missões, admitindo os missionários apenas como assistentes religiosos e educacionais dos diretores, mas, dada a impossibilidade de adotar este expediente, permitiam que os missionários exercessem eles próprios a função de diretores. A explicação para este paradoxo estava, em parte, no fato de o Estado não possuir recursos financeiros e humanos para promover a "catequese e civilização" dos índios.

Esta era a alegação dos administradores provinciais. Na verdade, o problema parecia ser muito mais a inexistência de uma política indigenista do que propriamente a falta de recursos. Não surpreende, portanto, que vários presidentes admitissem que o melhor "agente de civilização" do índio no Vale Amazônico era o regatão. Afinal, a principal mão-de-obra requerida para os trabalhos de coleta dos produtos da floresta era a indígena. Permitindo sua exploração pelos agentes envolvidos nos negócios da borracha, os presidentes conquistavam uma importante base de apoio para a realização da política imperial no Pará.

\footnotetext{
${ }^{124}$ Ibidem. p. 177-178.

${ }^{125}$ KARASCH, Mary. Op. cit. p. 406.
} 
Entre as perspectivas frustradas de fornecimento de braços para as lavouras, a imigração asiática ilustra bem até que ponto o Governo estava empenhado em auxiliar os fazendeiros a encontrar uma alternativa que, se não era tão atrativa quando a escravidão, pelo menos não parecia oferecer os mesmos riscos e a incerteza da imigração européia e da utilização do braço livre nacional. O que salta aos olhos nas investidas para contratar asiáticos é não apenas o desconhecimento, por parte dos interessados, das dificuldades que adviriam para que fosse estabelecido um acordo comercial com a China - devido às pressões das sociedades anti-escravistas internacionais - mas principalmente a carga de preconceito que se alimentava em relação àqueles povos. A associação entre agricultura e progresso demonstrava, assim, uma de suas facetas mais perversas.

É importante ressaltarmos que a perspectiva da imigração asiática não entusiasmou os Governantes e a elite paraense. A repercussão das investidas de Sinimbu nesse sentido foi muito pequena, tanto nos jornais como nos relatórios e falas dos presidentes. A explicação para isso parece estar no fato de que tal proposta coincidiu com o grande fluxo de migrantes nordestinos para a Amazônia, entre 1877 e o início da década de 1880. Naquela oportunidade, mesmo setores interessados em promover a imigração européia para o Vale Amazônico recuaram, sentindo-se atraídos pela possibilidade de, enfim, empregar a mão-de-obra livre nacional numa atividade produtiva e que consideravam vital para o desenvolvimento regional: a agricultura. Mas esta expectativa seria duplamente frustrada. 


\section{Capítulo III PERDIDOS NO “DESERTO”}

Na fala com que abriu a sessão da Assembléia Provincial do Pará em 1882, o Presidente da Província João José Pedrosa anexou um estudo intitulado "Indústria Extractiva - a Borracha", ${ }^{1}$ no qual seu autor, M. A. Pimenta Bueno, afirmou que as autoridades do Pará e Amazonas estavam sendo imprevidentes ao não incentivarem a agricultura. Segundo ele, nada prosperava naquelas Províncias além da borracha, que beneficiava apenas o fisco e os intermediários. A população - principalmente "tapuios" e cearenses fugidos das secas - permanecia em estado lastimável.

O próprio autor reconheceu que sua crítica não era uma novidade, o que, aliás, era uma forma de reforçá-la. Em 1862, o Presidente Araújo Brusque, já alertara, segundo ele, para o fato de que o lucro da borracha ficava nas mãos de poucos, sobrando para seus produtores diretos a ruína e a morte. Em vinte anos esta situação apenas se agravara, uma vez que os seringais virgens, portanto mais produtivos, estavam cada vez mais distantes. A possibilidade de esgotamento dos seringais teria sido prevista também no início da década de 1860. Silva Coutinho alertara, naquela oportunidade, para o fato de que não obstante a Lei de Terras de 1850 haver proibido a devastação de terras devolutas, os "processos selvagens" de exploração das drogas continuavam pondo em risco a produção futura.

Em suma, de acordo com Pimenta Bueno, o progresso do Pará era fictício e passageiro. Naqueles vinte anos, a única diferença era que, com a devastação dos seringais, intensificara-se a emigração para o Vale Amazônico e até mesmo para os países vizinhos. Sua proposta era a reforma da Lei de Terras, uma vez que tanto na região como em boa parte do país o que mais valia era o trabalho e não a posse da terra. Esta reforma deveria ser feita de modo a criar meios para fixar a população pelo trabalho metódico e regular, através da concessão de terras para o cultivo da seringueira

\footnotetext{
${ }^{1}$ Bueno, M. A. Pimenta. "Industria extractiva - a Borracha. Considerações por...”. In: Pará. Falla com que o exm.o snr. dr. João José Pedrosa abrio a 1.a sessão da 23.a legislatura da Assembléa Legislativa da provincia do Pará em 23 de abril de 1882. Pará, Typ. de Francisco da Costa Junior, 1882, Anexo, p. 47-62.
} 
ou de gêneros agrícolas. Tal medida, concluiu o autor, contribuiria não apenas para o progresso econômico, mas também moral da população. ${ }^{2}$

Ao longo das décadas de 1870 e 1880, foram fundadas pelo menos seis colônias agrícolas com o intuito povoar a Província, ampliar e diversificar sua produção agrícola. A maioria delas estava situada na região servida pela Estradas de Ferro de Belém a Bragança, o que contribuía para facilitar o escoamento dos produtos, uma vez que tanto em São Paulo como no Pará acreditava-se que a criação de núcleos coloniais distantes dos centros consumidores resultaria em fracasso.

Entretanto, inúmeras dificuldades se colocaram para a realização daqueles empreendimentos, provocando divergências entre os contemporâneos e criando um ambiente bastante pessimista. Alguns se tornaram muito cépticos quanto às possibilidades e viabilidades da importação de braços e, conseqüentemente, do incremento das atividades agrícolas; outros passaram a defender o aproveitamento dos migrantes cearenses, que abandonavam sua Província em virtude das secas, mas percebiam que isto beneficiaria principalmente as atividades extrativistas; um terceiro grupo limitou suas esperanças apenas à chamada "imigração espontânea", admitindo o envolvimento do governo apenas na subvenção de passagens e auxílio ao estrangeiro até sua instalação.

Parecia ganhar força a imagem que associava a Amazônia a um deserto, não pela aridez e quase ausência de vegetação, mas pela falta de seres humanos capazes de promover o seu progresso e civilização. As divergências entre os órgãos de imprensa, os partidos e a Administração Provincial talvez fosse ainda mais ampla, envolvendo outros setores da elite paraense, que não conseguiam unir-se em torno de propostas mais efetivas para fomentar a produção agrícola da Província. Imigração ou colonização? Europeus ou cearenses? Extrativismo ou agricultura?

Tantas indefinições deixavam o Pará cada vez mais longe dos recursos que o governo imperial colocava à disposição das províncias para o financiamento da transição para o trabalho livre. Mas, por outro lado, elas estimularam o debate e a reflexão entre os agentes envolvidos nos negócios da borracha, os políticos e os grupos interessados em promover o desenvolvimento regional através do aproveitamento dos

\footnotetext{
${ }^{2}$ Pará. Falla com que o exm. snr. Dr. João José Pedrosa abrio a $1^{a}$. sessão da $23^{a}$. legislativa da Assembléa Legislativa da Provincia do Pará, em 9 de abril de 1882. Belém: Typ. de Francisco da Costa Junior, 1882, Annexo, p. 47-62.
} 
braços disponíveis no Vale Amazônico, sobretudo dos índios e libertos, da inserção do estrangeiro ou do cearense.

\subsection{A salvação da lavoura}

Em meados da década de 1870, as expectativas em relação à imigração norteamericana já haviam se desvanecido. Na colônia de Santarém restavam poucos colonos, ocupando não mais do que dezesseis estabelecimentos. Embora se ressaltasse que sua produção supria o mercado daquela cidade e que eles estavam contentes no seu "gênio ativo e industrioso", 3 poucos cogitavam a possibilidade de que os Estados Unidos se tornassem uma nova fonte de suprimento de braços para a região.

Segundo Palma Muniz, ${ }^{4}$ as razões para o fracasso da imigração norteamericana estavam na morosidade do processo de vendas e medições de terras. Ernesto Cruz, ${ }^{5}$ por sua vez, citou argumentos dos presidentes Pedro Vicente de Azevedo e Abel Graça, para os quais a maioria dos colonos era formada pessoas aventureiras, inadequadas para a "penosa vida de colonos agrícolas", preguiçosas e imprevidentes, que só permaneceram em Santarém enquanto o governo as sustentou. Não obstante, o autor concluiu que os colonos norte-americanos deixaram em Santarém a marca de seu “espírito laborioso e prático”, preferindo concordar, portanto, com opiniões favoráveis à experiência, entre elas a que foi citada acima, de Francisco Maria Corrêa de Sá e Benevides.

De acordo com Frank Goldman, ${ }^{6}$ dos norte-americanos que tentaram se estabelecer no Brasil, apenas um pequeno grupo, instalado próximo a Campinas, conseguiu êxito relativo. No Pará, Ceará, Pernambuco, Bahia, Espírito Santo, Paraná, Santa Catarina, Rio de Janeiro e litoral sul de São Paulo as colônias logo fracassaram. Uma das razões apontadas pelo autor é o fato de terem se dirigido para áreas onde suas

\footnotetext{
${ }^{3}$ Pará. Relatorio apresentado pelo exm. sr. dr. Francisco Maria Corrêa de Sá e Benevides, Presidente da Provincia do Pará, á Assembléa Legislativa Provincial na sua sessão solemne de installação da $20^{a}$. legislatura, no dia 15 de fevereiro de 1876. Belém: Typ. do "Diario do Gram-Pará", 1876, p. 50-52.

${ }^{4}$ MUNIZ, Palma. Estado do Grão-Pará. Immigração e Colonização. História e Estatística. 1616-1916. Belém: Imprensa Official do Estado do Pará, 1916. p. 32-33.

${ }^{5}$ CRUZ, Ernesto. Colonização do Pará. Belém: Instituto Nacional de Pesquisas Amazônicas, 1958. p. 39-40.

${ }^{6}$ GOLDMAN, Frank. Aspectos das migrações norte-americanas após a Guerra Civil. In: HOLANDA, Sérgio Buarque de (dir.). História Geral da Civilização Brasileira. 2. ed. São Paulo: Difel, 1969. p. 272273.
} 
técnicas agrícolas não eram adequadas (áreas que exigiam, pelas próprias condições do solo, o uso da enxada). Muitos deles eram produtores de algodão, cultura pouco desenvolvida no Brasil, que requeria mão-de-obra treinada para lidar com arados e outros maquinismos.

Em 1875, Francisco Maria Corrêa de Sá e Benevides, ${ }^{7}$ registrou a chegada em Belém de vinte imigrantes, enviados da Corte por uma agência oficial de colonização, mas este número era insignificante diante das dimensões da Província e de suas necessidades em termos de povoamento e produção de alimentos. Além da dificuldade em atrair estrangeiros, havia obstáculos internos às tentativas oficiais para promover a colonização. Atendendo a um aviso do Ministério da Agricultura, o mesmo Administrador enviou circulares às Câmaras Municipais para que fossem prestadas informações sobre as condições que cada localidade oferecia à colonização. Entretanto, apenas as de Curralinho, Mojú, Muaná e Cametá teriam respondido, alegando, as duas primeiras, que não havia na região áreas disponíveis para a colonização, pois os terrenos seriam alagadiços; já as duas últimas, que não havia áreas públicas disponíveis. ${ }^{8}$

Diante desses problemas, Francisco Maria Corrêa de Sá e Benevides constituiu uma comissão para providenciar o recebimento e acolhimento de imigrantes, composta por agentes consulares da Alemanha, França e Espanha. ${ }^{9}$ Uma área situada nas proximidades da Estrada de Ferro de Belém a Bragança foi cedida e a comissão batizou o núcleo colonial com o nome de Benevides, em homenagem ao Presidente. ${ }^{10}$ Era o princípio de uma das colônias mais conhecidas e polêmicas do Pará. Ali foram instalados, inicialmente, 20 colonos europeus; mais tarde, esse número foi elevado para 161, reduzindo-se a 43, pois alguns imigrantes teriam abandonado o local, por não suportarem o peso dos trabalhos agrícolas. ${ }^{11}$

\footnotetext{
${ }^{7}$ Pará. Relatorio com que o excellentissimo senhor Doutor Francisco Maria Corrêa de Sá e Benevides Presidente da Provincia abriu a $2^{a}$. sessão da $19^{a}$. legislatura da Assembléa Legislativa Provincial no dia 15 de fevereiro de 1875. Belém: Typ. do Diario do Gram-Pará, 1875.

${ }^{8}$ Ibidem. p. 12. Observa-se assim que havia na região amazônica uma resistência à execução da Lei de Terras de 1850, a exemplo do que, segundo José Murilo de Carvalho, ocorria em outras regiões. Ver: CARVALHO, José Murilo de. "A Política de Terras: O veto dos barões". In: Idem. Teatro de Sombras: A Política Imperial. Rio de Janeiro: IUPERJ; São Paulo: Vértice/Editora Revista dos Tribunais, 1988. p. 84106.

${ }^{9} \mathrm{O}$ cônsul dos Estados Unidos no Norte, Antonio Gonçalves Nunes, teria recusado convite para fazer parte da comissão. MUNIZ, Palma. Op. cit. p. 35.

${ }^{10}$ De acordo com Palma Muniz, o nome foi mudado posteriormente para Colônia Santa Isabel de Benevides, porém o nome original era o mais utilizado. Ibidem. loc. cit.

${ }^{11}$ Pará. Relatorio apresentado pelo exm. sr. dr. Francisco Maria Corrêa de Sá e Benevides, Presidente da Provincia do Pará, á Assembléa Legislativa Provincial na sua sessão solemne de installação da $20^{a}$.
} 
Após a tentativa fracassada de instalar colonos norte-americanos em Santarém e europeus em Benevides, muito se discutiu em Belém sobre a capacidade de os estrangeiros se adaptarem às condições naturais da Amazônia. João Capistrano Bandeira de Mello Filho, ${ }^{12}$ por exemplo, argumentou que não seria este o problema, mas a falta de planejamento, de condições de transporte e infra-estrutura, de mais colônias e de apoio oficial para dar ao imigrante condições de trabalho semelhantes às do seu país de origem. Por outro lado, era preciso escolher com cuidado os imigrantes, pois muitos deles não eram agricultores nem revelavam "amor ao trabalho e à propriedade territorial". 13

O Presidente acusou, assim, o Governo Imperial de tratar de forma diferenciada as regiões Norte e Sul na questão dos incentivos à imigração e colonização. Esta crítica talvez possa ser explicada pela origem de sua família e atuação política. Seu pai governou as Províncias da Paraíba, Alagoas, Bahia, Minas Gerais e Ceará, tendo sido eleito por esta última para Câmara dos Deputados; ele, por sua vez, foi Presidente do Maranhão, Santa Catarina, Sergipe e, por duas vezes, do Rio Grande do Norte, além do Pará, evidentemente. ${ }^{14}$ É provável, portanto, que com essa trajetória política, incluindo a do seu progenitor, o Presidente se identificasse mais com os interesses da região Norte do que com os do gabinete ministerial que representava.

Por fim, João Capistrano Bandeira de Mello Filho decidiu introduzir em Benevides trabalhadores nacionais "moralisados e aptos para a lavoura", afirmando acreditar que a convivência entre brasileiros e estrangeiros daria mais animação,

legislatura, no dia 15 de fevereiro de 1876. Belém: Typ. do Diario do Gram-Pará, 1876, p. 48-50. Sobre a colônia americana de Santarém, Francisco Benevides assegurou que apesar de ter poucos colonos, não mais que 16 estabelecimentos, era um núcleo importante, pois já supria o mercado daquela cidade. Os imigrantes viviam ali contentes no seu "gênio ativo e industrioso". Pará. Relatorio apresentado pelo exm. sr. dr. Francisco Maria Corrêa de Sá e Benevides, Presidente da Provincia do Pará, á Assembléa Legislativa Provincial na sua sessão solemne de installação da $20^{a}$. legislatura, no dia 15 de fevereiro de 1876. Belém: Typ. do Diario do Gram-Pará, 1876, p. 50-52.

${ }^{12}$ Para reforçar seu ponto de vista, João Capistrano Bandeira de Mello Filho mencionou o "sábio" Agassiz, que teria "emitido juizo que desvaneceu o preconceito de ser o clima desta Província prejudicial aos naturaes de zona differente". Pará. Falla com que o exm. sr. dr. João Capistrano Bandeira de Mello Filho abrio a 2.a sessão da 20.a legislatura da Assemblea Legislativa da provincia do Pará em 15 de fevereiro de 1877. Pará, Typ. do Livro do Commercio, 1877. p. 157.

${ }^{13}$ Ibidem. p. 158.

${ }^{14}$ A identificação da origem dos administradores das províncias demanda uma pesquisa minuciosa. Os Relatórios e Falas não trazem estas informações, que podem ser encontradas, algumas vezes, nos jornais, quando de sua posse. O fato de João Capistrano Bandeira de Mello ter sido eleito deputado pela província do Ceará é um indício de que a família era natural daquela província. Entretanto, não era vedada a possibilidade de um político de uma província se eleger por outra. Mais importante, contudo, é o fato de ambos terem administrado principalmente províncias da região que, no século XIX, era designada como Norte. 
estímulo e colaboração para trabalho. ${ }^{15}$ A idéia de que o contato entre estrangeiros e nacionais seria benéfico para estes últimos, em termos de predisposição para o trabalho, denota uma concepção comum à maioria dos administradores e políticos daquele período: a crença na indolência dos brasileiros. A imigração européia não era pensada, portanto, apenas como uma alternativa de suprimento de braços, mas principalmente como uma forma de transformar a mentalidade dos trabalhadores nacionais. Projetavam-se, assim, nos europeus, em sentindo inverso, características percebidas como negativas nos trabalhadores brasileiros.

Os novos colonos de Benevides, aos quais o Presidente se referia, não eram paraenses, mas cearenses recém-chegados ao Pará, fugindo das secas que assolavam sua Província. Logo nos primeiros meses de 1878, ele afirmou que Benevides estava se transformando em um núcleo de imigrantes cearenses. ${ }^{16}$ Um primeiro grupo de cerca de oitocentos trabalhadores já teria sido instalado em "solo fértil", recebido instrumentos de trabalho e capitais. Assim, os recursos que pareciam faltar para o estabelecimento de trabalhadores europeus surgiram e foram empregados na acomodação dos cearenses.

Ainda em 1878, José Joaquim do Carmo declarou que a seca no Ceará estava oferecendo ao Pará a oportunidade de aliar seus "legítimos interesses" aos "sentimentos humanitários". ${ }^{17}$ Nesse sentido, disponibilizara recursos para o acolhimento dos flagelados e solicitara à presidência daquela Província uma lista circunstanciada com a idade, sexo, estado, profissão e nomes de parentes interessados em partir para a Amazônia. Outras medidas tomadas teriam sido a contratação de cearenses para construir, em Benevides, barracões que acomodassem mais trabalhadores, o estabelecimento de comunicação por terra e mar entre a colônia e a capital e a demarcação de novos lotes. ${ }^{18}$

Os administradores provinciais e redatores de jornais passaram, a partir de então, a dar grande destaque às possibilidades de utilização da mão-de-obra dos migrantes que abandonavam a Província do Ceará em virtude das secas. Embora não

\footnotetext{
${ }^{15}$ A medida contribuiria também para "concentrar da população" local, muito esparsa, quase nômade e sem domicilio fixo, atraindo-a para a "vida agricola". Ibidem. p 160.

${ }^{16}$ Pará. Relatorio com que ao exm. sr. Dr. José da Gama Malcher, $1^{o}$. Vice-Presidente passou a administração da provincia do Pará o exm. sr. Dr. João Capistrano Bandeira de Mello Filho em 9 de março de 1878. Belém: Typ. Guttemberg, 1878, p. 89.

${ }^{17}$ Pará. Falla com que o exm. senr. Dr. José Joaquim do Carmo abrio a $1^{a}$. sessão da $21^{a}$. legislatura da Assembléa Legislativa da Provincia do Pará em 22 de abril de 1878. Belém: Typ. da Provincia do Pará, 1878.

${ }^{18}$ Ibidem. p. 6-7.
} 
abandonassem por completo as expectativas em relação à importação de imigrantes europeus e à catequese e civilização dos índios, eles pareciam acreditar que o trabalhador nacional era a alternativa mais viável para o incremento da agricultura do Pará.

Os relatórios e falas dos administradores que presidiram a Província nos anos posteriores confirmam a chegada de grandes levas de migrantes nordestinos no Pará, o que, por outro lado, ressaltou as precárias condições de infra-estrutura da Província. A Santa Casa de Misericórdia, por exemplo, não conseguia atender os recém-chegados e necessitou passar por reformas. Em um ano, centenas de enfermos cearenses haviam ali chegado, com sintomas de hepatite, disenterias, febres intermitentes, febre amarela, beribéri e reumatismo, numa média de 30 internações por mês. A Comissão de Colonização, criada alguns anos antes para promover a imigração européia e dar apoio aos colonos estabelecidos na Província, foi encarregada de atender às solicitações para tratamento dos cearenses enfermos, mas não dispunha de recursos para fazê-lo. ${ }^{19} \mathrm{~A}$ Administração Provincial teve, então, de arcar com os custos e cogitou construir uma enfermaria exclusiva para tratar dos retirantes doentes. ${ }^{20}$

Outras medidas tiveram que ser tomadas para reverter a situação em que se encontrava a Província, descrita por José Joaquim do Carmo como "um espetáculo de inação e miséria". ${ }^{21}$ A força policial da Província foi ampliada, pois crescia o número de crimes. $^{22}$ Das 2.458 mortes registradas na capital, nada menos do que 1.013 eram de retirantes cearenses, o que obrigava a administração a expandir os cemitérios existentes ou criar outros. ${ }^{23}$

Diante desses problemas, os administradores começaram a ficar divididos entre considerar benéfica ou problemática a imigração cearense. José Joaquim do Carmo, por exemplo, destacou a contribuição dos cearenses para o incremento da produção e,

\footnotetext{
${ }^{19}$ Ibidem. p. 28.

${ }^{20}$ Ibidem. p. 6-7.

21 José Joaquim do Carmo determinou que os retirantes cearenses recebessem suprimentos até a sua acomodação em prédios salubres; que os chefes de família respondessem por seus "subordinados"; que os que quisessem ir para o Amazonas fossem transportados imediatamente e os demais que fossem empregados em obras públicas ou na agricultura; que os responsáveis pelos retirantes não consentissem que eles mendigassem, comunicando à administração quando não pudessem mantê-los. Ibidem. p. I-II.

22 Ibidem. p. 11.

${ }^{23}$ Pará. Falla com que o excellentissimo senhor Doutor José Coelho da Gama e Abreu Presidente da Provincia abriu a $2^{a}$. sessão da $21^{a}$. legislatura da Assembléa Legislativa da Provincia do Gram-Pará em 16 de junho de 1879. Belém: Typ. do Liberal do Pará, 1879. p. 161.
} 
conseqüentemente, das finanças provinciais. ${ }^{24}$ Para José Coelho da Gama e Abreu, porém, eles exauriam os recursos provinciais. $^{25}$ Este Administrador se mostrou preocupado, também, com a excessiva concentração de imigrantes cearenses nas colônias de Benevides, Tentugal, Santarém e Santa Izabel. De acordo com ele, os recém-chegados exigiam que o governo os sustentasse indefinidamente, criando dificuldades para a direção dos núcleos coloniais. Somente em Benevides estariam instaladas nove mil pessoas, aproximadamente, o que aumentava os gastos e dificultava o bom aproveitamento dos lotes. Na tentativa de contornar o problema, ordenara que a cada três léguas da Estrada de Ferro de Belém a Bragança fossem estabelecidos núcleos de mil imigrantes. ${ }^{26}$

A instalação de um número de colonos muito acima do que aquele para a qual a colônia de Benevides fora projetada pode ter dado origem a vários conflitos. De acordo com José Coelho da Gama e Abreu, instigados por um capelão, alguns retirantes, descontentes com a redução dos recursos destinados ao núcleo, teriam investido contra o diretor, sendo, porém, contidos com "medidas enérgicas". ${ }^{27}$ A direção do núcleo reclamou, então, não apenas do grande número de cearenses no local, mas da falta de recursos, da difícil convivência entre cearenses e estrangeiros e da insuficiência da força policial. Tudo isto contribuíra, segundo o diretor, para o "estado de abalo da segurança individual e de propriedade". ${ }^{28}$

José Coelho da Gama e Abreu transferiu a culpa pela falta de recursos para o Governo Imperial. ${ }^{29}$ Irritados e insuflados por alguns mais exaltados, os colonos teriam

\footnotetext{
${ }^{24}$ Pará. Falla com que o exm. senr. Dr. José Joaquim do Carmo abrio a $1^{a}$. sessão da $21^{a}$. legislatura da Assembléa Legislativa da Provincia do Pará em 22 de abril de 1878. Belém: Typ. da Provincia do Pará, 1878. p. 15.

${ }^{25}$ Pará. Falla com que o excellentissimo senhor Doutor José Coelho da Gama e Abreu Presidente da Provincia abriu a $2^{a}$. sessão da $21^{a}$. legislatura da Assembléa Legislativa da Provincia do Gram-Pará em 16 de junho de 1879. Belém: Typ. do Liberal do Pará, 1879. p. 15.

${ }^{26}$ Ibidem. p. 19-20.

27 Pará. Relatorio apresentado pelo excellentissimo senhor doutor José Coelho da Gama e Abreu, Presidente da Provincia, á Assembléa Legislativa Provincial do Pará, na sua $1^{a}$. sessão da $22^{a}$. legislatura, em 15 de fevereiro de 1880. Belém: Typ. do Liberal do Pará, 1880. p. 5-6.

${ }^{28}$ Ibidem. p. 6.

${ }^{29}$ Várias obras estariam sendo realizadas em Benevides com subsídios do governo geral, que teria reduzido em mais de $50 \%$ os recursos. A exemplo do que fizera João Capistrano Bandeira de Mello Filho, José Coelho da Gama e Abreu, que era natural da província, reclamava da falta de apoio do Governo Imperial para promover a colonização e imigração no Grão-Pará. Assim, embora pertencessem a partidos distintos - o primeiro era conservador e o segundo, liberal - pareciam estar de acordo em relação a esta questão.
} 
ameaçado ir à capital buscar os recursos. ${ }^{30}$ De acordo com o Presidente, a colônia contava com oito mil pessoas, tendo já saído mil e quinhentos, em sua maioria pessoas "turbulentas", que haviam migrado para a Província apenas para aguardar o fim das secas no Ceará. ${ }^{31}$ Como a guarda urbana era composta de muitos retirantes cearenses, temia-se que ela não prendesse os revoltosos. ${ }^{32}$

Apesar das críticas dirigidas aos cearenses estabelecidos em Benevides, José Coelho da Gama e Abreu assinalou que 174 dos 280 lotes demarcados já estavam roçados e plantados; havia também 130 casas, além daquelas para o diretor, o padre e o professor, uma igreja, duas capelas e uma residência para o governo. ${ }^{33}$ Todas teriam sido construídas pelos cearenses que ali residiam. ${ }^{34}$ A exemplo de vários outros administradores, ele insistiu na necessidade de serem investidos recursos para concluir a construção da Estrada de Ferro de Belém a Bragança. A lei provincial que tratava do assunto criava dificuldades para a introdução de colonos, principalmente no que se referia à concessão de subsídios para o pagamento de passagens e sustento até que eles começassem a produzir. ${ }^{35}$

Em contrapartida, a Administração Provincial já teria feito uma série de gastos em Benevides, com desmatamentos, abertura de estradas e construção de pontes. ${ }^{36} \mathrm{~A}$ colônia também já não apresentava um grande excedente populacional, pois a abundância de chuvas no Ceará, o "natural apego à terra natal" e a atração exercida pelos negócios da borracha contribuíra para que muitos deixassem o local. Havia,

\footnotetext{
${ }^{30}$ Ibidem. p. 14.

${ }^{31}$ Ibidem. p. 25-28.

32 Ibidem. p. 45.

${ }^{33}$ Pará. Falla com que o excellentissimo senhor Doutor José Coelho da Gama e Abreu Presidente da Provincia abriu a $2^{a}$. sessão da $21^{a}$. legislatura da Assembléa Legislativa da Provincia do Gram-Pará em 16 de junho de 1879. Belém: Typ. do Liberal do Pará, 1879. p. 21.

${ }^{34}$ O Relatório do Diretor do núcleo colonial Benevides, Antonio Bernardino Jorge Sobrinho, publicado como anexo ao de Gama e Abreu, informou que existiam no total 985 prédios e 672 lotes, restando 87 por distribuir. Em julho de 1879, haveria 7.486 colonos ali estabelecidos. Segundo o diretor, alguns colonos que haviam se mudado para o Anajás, atraídos pelo trabalho de extração da seringa, retornaram mais pobres do que quando partiram. É provável que os dados fornecidos por Gama e Abreu fossem relativos apenas à área ocupada pelos cearenses. Ibidem. Annexos, p. XXXII-XLVII.

${ }^{35}$ Ibidem. p. 17-18.

${ }^{36}$ Pará. Relatorio apresentado a Assembléa Legislativa Provincial na $2^{a}$. sessão da $22^{a}$. legislatura, em 15 de fevereiro de 1881, pelo exm. sr. dr. José Coelho da Gama e Abreu. Belém: Typ. do "Diario de Noticias", 1881. p. 30.
} 
contudo, denúncias de que a saída dos colonos estava relacionada à sua má administração, com as quais o Presidente não concordava. ${ }^{37}$

As críticas de Gama e Abreu à conduta dos cearenses e à maneira como se referia aos colonos de outras nacionalidades revelavam sua preferência pela imigração européia. Segundo ele, os colonos europeus haviam implantado em Benevides engenhos a vapor para fabricação de cachaça e açúcar e um o novo sistema de transporte. Em razão disso, concedera isenção de impostos provinciais aos que ainda permaneciam no núcleo, afirmando que eles simbolizavam o imigrante útil ao país, pois, com o vigor de seus braços, aumentavam suas posses e estimulavam outros pelo exemplo. ${ }^{38}$ Os outros, neste caso, eram os trabalhadores nacionais, que o Administrador considerava inferiores aos imigrantes.

Alguns anos mais tarde, surgiram notícias do envolvimento dos cearenses estabelecidos em Benevides como o movimento abolicionista. No dia 30 de março de 1884, ou seja, cinco dias após a libertação dos cativos do Ceará, a colônia também foi declarada uma "área livre de escravidão". ${ }^{39}$ Posteriormente, quando da inauguração do trecho da Estrada de Ferro de Belém a Bragança, ligando a capital à colônia, o Presidente da Companhia, que ficara conhecido em Belém por publicar artigos nos jornais elogiando o movimento abolicionista cearense, distribuiu cartas de alforrias a vários escravos. ${ }^{40}$ Esta e outras circunstâncias teriam feito com a colônia ficasse conhecida como "mocambo Benevides", supostamente por se tornar um abrigo seguro para escravos fugidos. ${ }^{41}$

\footnotetext{
${ }^{37}$ O Relatório do Diretor do núcleo Benevides, Antonio Bernardino Jorge Sobrinho, publicado nos anexos do Relatório de Gama e Abreu, assinalava que o desenvolvimento de Benevides dependia da comunicação com a capital. Como não havia recursos para a construção de uma ferrovia, iniciou-se a abertura de uma estrada entre Benevides e o porto de Benfica. Existiam no núcleo 985 prédios e 672 lotes, restando 87 por distribuir. Em julho de 1879, havia 7.486 colonos. Muitos teriam se mudado para Anajás, inclusive professores das escolas, atraídos pelo trabalho na extração da seringa, regressando depois mais pobres. Ibidem. Annexos. p. XXXII-XLVII

${ }^{38}$ Ibidem. p. 43-45.

${ }^{39}$ SALLES, Vicente. O Negro no Pará - Sob o Regime da Escravidão. Rio de Janeiro: Fundação Getúlio Vargas, 1971. p. 307.

${ }^{40}$ Existem divergências entre os autores acerca de detalhes envolvendo o episódio. Segundo Rosa Elisabeth Acevedo Marin foram distribuídas 6 cartas de alforrias; Ernesto Cruz afirma que foram 20 cartas. Além disso, de acordo com este autor, tais escravos residiam em Benevides, mas Vicente Salles afirma que desde 30 de março daquele ano não havia mais escravos na Colônia. É possível que em mais de uma oportunidade tenham sido distribuídas cartas de alforria em Benevides, mesmo após a colônia ter sido declarada área livre de escravidão. Ver, além dos texto citado de Vicente Salles, ver: ACEVEDO MARIN, Rosa Elizabeth. "O Pará e o movimento abolicionista". Acervo, Rio de Janeiro, 3 (1): 21-36, jan./jun. 1988; p. 41; CRUZ, Ernesto. História do Pará. Op. cit. Vol. 2. p. 590.

${ }^{41}$ MARIN, Rosa Elisabeth Acevedo. Op. cit. p. 33.
} 
Em 1884, o conselheiro João Silveira de Souza afirmou que mais de 40 escravos, comandados por José Ferreira Braga, invadiram uma capela em Benevides para auxiliar a fuga de uma escrava, ferindo dois policiais. ${ }^{42} \mathrm{O}$ jornal $A$ Vida Paraense, do desenhista e escritor maranhense João Afonso do Nascimento, estampou na sua edição de 30 de março daquele ano uma litografia, ${ }^{43}$ na qual uma índia representava a Amazônia, assinando a carta de "redenção" de Benevides. Em segundo plano, o caricaturista retratou a estrada de ferro em construção, que ligaria a capital à cidade de Bragança, passando pela Colônia, e, na parte inferior, inscreveu uma legenda em que afirmava o propósito de "limpar" do território amazônico a "nodoa aviltante da escravidão", "sem perturbação da ordem e do direito. ${ }^{44}$

Os incidentes ocorridos em Benevides podiam estar relacionados, também, com o pânico que atingia o Pará em meados da década de 1880 devido à ação de quilombolas. Na fala com que abriu os trabalhos da Assembléia Provincial, no início de 1884, o Presidente Visconde de Maracaju relatou que o chefe de polícia se dirigira à região de Cametá, onde nove quilombolas, ao se dirigirem a outra propriedade em que ocorreria uma festa de São João, provocaram receios de que ocorresse um levante de toda escravaria da região. Na perseguição aos quilombolas, o Administrador de uma fazenda acabou sendo ferido com tiros de espingarda, o que levou o chefe de polícia a solicitar providências da Administração Provincial para a destruição de alguns quilombos localizados nas proximidades de um grande lago. Haveria nestes quilombos mais de quinhentas pessoas, que mantinham comércio com Oeiras, Tabatinga e Cupuás. $^{45}$

Entre os jornais publicados em Belém, o Diário de Notícias era um dos principais incentivadores da proposta de utilização dos cearenses no povoamento e na produção agrícola do Vale Amazônico. Os redatores deste jornal demonstravam pouco entusiasmo em relação às possibilidades de introdução de trabalhadores europeus na

\footnotetext{
${ }^{42}$ Pará. Falla com que o exm. senr. conselheiro João Silveira de Sousa, abriu a $1^{a}$. sessão da $25^{a}$. legislatura da Assembléa Legislativa Provincial em 15 de outubro de 1884. Belém: Typ. de Francisco da Costa Junior, 1885.

${ }^{43}$ A IDÉIA caminha. A Vida Paraense, 30/03/1884, apud SALLES, Vicente. Op. cit. p. 310.

${ }^{44}$ Segundo Rosa Elisabeth Acevedo Marin, a libertação dos cativos e as homenagens à "redenção" do Ceará em Benevides tiveram um caráter apenas simbólico, pois os imigrantes estrangeiros não podiam ser proprietários de escravos e os cearenses não tinha recursos para adquiri-los.

${ }^{5}$ Pará. Falla com que o exm. sr. General Visconde de Maracajú Presidente da Provincia do Pará, pretendia abrir a sessão extraordinaria da respectiva Assembléa no dia 7 de janeiro de 1884. Pará, Diario de Noticias, 1884. p. 35-38.
} 
região, apresentando como principais argumentos o fato de a mesma não se encontrar em condições de competir com outras regiões do próprio país na atração dos imigrantes vindos da Europa, as dificuldades que estes teriam para se adaptar às condições naturais da Amazônia e as incertezas quanto ao seu caráter e aptidão para o trabalho agrícola.

A partir de 1884, ou seja, três anos após ter sido fundado, o Diário de Notícias intensificou seus pedidos para que fosse adotada uma política mais efetiva de atração dos migrantes cearenses. É possível que esta orientação estivesse relacionada com a emancipação dos escravos daquela Província, uma vez que o jornal era um dos que mais se destacava no apoio ao movimento abolicionista. ${ }^{46}$ Utilizando como estratégia sua suposta imparcialidade política, visto que não se tratava de um órgão de partido, o Diário de Notícias se colocava na condição de porta-voz dos interesses da Província e falava em nome dos que almejavam o seu progresso. De acordo com os redatores, era preciso preparar o terreno para que a abolição não colocasse em risco a incipiente prosperidade proporcionada até aquele momento pela economia da borracha. Nada mais natural, portanto, do que acolher os cearenses, que, ao se anteciparem àquela decisão inevitável, teriam mostrado ser um povo pacífico, ordeiro e previdente.

Alguns anos mais tarde, exatamente no dia em que se comemorava a emancipação dos escravos do Amazonas, o Diário de Notícias voltou a insistir nessa idéia ao comentar um projeto de lei apresentado no Parlamento pelo Senador e exMinistro Manoel de Sousa Dantas. Tal projeto marcava para 31 de dezembro de 1889 a abolição da escravatura e propunha a criação de um código rural. De acordo com o redator do jornal, esta última medida teria como propósito evitar que o fim da escravidão provocasse um aumento do número de vagabundos, ociosos e ladrões, os quais poderiam conturbar a sociedade brasileira em vista de sua péssima organização policial. Esta expectativa, porém, não seria fruto da experiência vivenciada pelas duas Províncias que já haviam emancipado seus escravos, pois, segundo ele, nenhuma delas havia "sofrido" com a abolição, tanto que a "lei do trabalho rural" ia espontaneamente aparecendo em ambas. ${ }^{47}$

\footnotetext{
${ }^{46}$ Após o dia 25 de março de 1884 foram publicados vários artigos sobre as comemorações da "redenção do Ceará" na imprensa paraense. Posteriormente, os redatores continuaram defendendo a idéia da importação de braços cearenses. Ver:A IMMIGRAÇÃO cearense", Diário de Notícias, 27/07/1887. [Editorial].

${ }^{47}$ [Sem título], Diário de Notícias, 10/07/1887, "Entre-columnas".
} 
Cada vez menos entusiasmado com as possibilidades de introdução de imigrantes europeus na Província, o Diário de Notícias continuou insistindo na idéia de se utilizar os braços disponíveis no país, principalmente os dos migrantes cearenses. Segundo seu redator, a demora em promover a abolição final tornaria necessária a adoção de uma legislação que reprimisse a ociosidade e a vadiagem. Afinal, o Ceará e o Amazonas não apresentavam problemas de suprimento de mão-de-obra e de segurança e tranqüilidade pública exatamente porque haviam abolido a escravidão. Assim, utilizando como pretexto a abolição iminente e a suposta necessidade de serem tomadas providências para evitar qualquer consequiência nefasta que ela pudesse acarretar, o redator preconizava a adoção de medidas coercitivas para direcionar os braços disponíveis no sentido do trabalho produtivo.

Mas, para isso, era preciso desacreditar aquelas que propunham a introdução de trabalhadores estrangeiros. Em diversas ocasiões, o Diário de Notícias acusou os adeptos da imigração européia de buscarem auferir vantagens econômicas e políticas ao tentarem por em prática esta alternativa de suprimento de mão-de-obra. Coincidência ou não, o fato é que a maioria dos periódicos que incentivavam a importação de braços de outros países estava diretamente envolvida com o jogo político-partidário naquele momento, como os jornais A Constituição e o Diário de Belém, ambos ligados ao Partido Conservador; o Liberal do Pará e o A Província do Pará, vinculados ao Partido Liberal. A exceção ficava por conta do Diário do Gram-Pará, órgão do Partido Conservador, que criticava o apoio dos governos provinciais à agricultura e à imigração em detrimento da produção extrativa. As divergências, portanto, não se restringiam aos órgãos de agremiações concorrentes, visto que periódicos ligados a um mesmo partido político discordavam quanto ao caminho a ser seguido para a solução da "magna questão".

Segundo Palma Muniz, cujo trabalho, conforme assinalamos, baseou-se principalmente nos relatórios e falas dos presidentes da Província, servindo de base, por sua vez, para várias análises de autores como Ernesto Cruz, ${ }^{48}$ Benevides fracassou como colônia estrangeira devido a vários fatores, entre os quais deficiências no recrutamento dos trabalhadores, ausência de um serviço bem organizado de apoio a eles e o elevado custo do núcleo para os cofres provinciais. Além disso, os trabalhadores brasileiros que

\footnotetext{
${ }^{48}$ CRUZ, Ernesto. Colonização do Pará. Belém: Inst. Nac. de Pesq., 1958. p. 61-67.
} 
lá se instalaram teriam demonstrado melhor aproveitamento e rendimento do que o imigrante europeu, levando os administradores a preferirem a instalação de colônias mistas.

A partir de 1880, até a proclamação da República, as atenções, em termos de criação de núcleos coloniais, dos administradores se voltaram quase todas para a região da Estrada de Ferro de Belém a Bragança, cuja construção teve início em 1883. Isto pode ter contribuído para o desenvolvimento da colônia Benevides, uma vez que a maioria dos presidentes apontava seu isolamento como principal obstáculo. Porém, o que se nota é seu quase total abandono pelos administradores provinciais. Após os conflitos registrados por Gama e Abreu, o diretor teria abandonado o local, passando a colônia a ser administrada pelos próprios moradores.

\subsection{Insatisfeitos}

A Administração Provincial do Pará criou uma Comissão de Colonização e a encarregou de tratar dos assuntos relativos à colônia Benevides. Durante o ano de 1876, o jornal Diário de Belém publicou as atas das reuniões realizadas pela Comissão, as quais nos permitem conhecer um pouco do dia-a-dia de Benevides, das relações entre os colonos, entre eles e a administração do núcleo. As atas contêm um impressionante número de pedidos e reivindicações, desde as questões mais comezinhas, como tamancos e solicitações de envio de cartas para seus parentes, até questões contratuais. Considerando-se a importância deste núcleo para a política imigrantista no Pará e o fato de as atas terem sido amplamente divulgada, é possível que o exposto nas atas tenha desempenhado um papel importante na construção da imagem do trabalhador europeu na região.

Um número significativo de pedidos diz respeito às "comedorias", ou seja, itens de alimentação básica, até que as lavouras começassem a produzir. Os contratos assinados pelos colonos com a Administração Provincial davam a eles o direito de receber alimentos e víveres por um prazo que se acredita suficiente para que pudessem produzir seu próprio sustento. Mas uma série de imprevistos os obrigavam a solicitar a extensão do prazo, o que também gerava desconfiança por parte do diretor e da Comissão. 
As solicitações às vezes eram feitas individualmente, como em janeiro de 1876, quando a Comissão informou que um colono francês solicitara alimentação por mais alguns dias por ainda não ter conseguido ocupação nem estar devidamente alojado; ${ }^{49}$ ou coletiva, quando, alguns dias mais tarde, outros colonos solicitaram a prorrogação do prazo das "comedorias", por meio de um ofício encaminhado através do diretor da colônia à Comissão. ${ }^{50}$ Aliás, os colonos não podiam se dirigir diretamente à Comissão, muito menos à presidência da Província ou qualquer outra autoridade sem que fosse através do diretor. Este, por sua vez, encaminhava as solicitações à Comissão, que as repassava ao Presidente da Província. ${ }^{51}$ Em geral, quando bem fundamentadas, elas eram atendidas, como foi o caso dos colonos que se pronunciaram por escrito, os quais tiveram o prazo de suas "comedorias" prorrogado por mais três meses. ${ }^{52}$

As atas da Comissão revelam também que havia da parte dos colonos alguma iniciativa no sentido de se organizar e apresentar as solicitações coletivamente. É provável que percebessem ser esta uma forma mais eficiente de pressão. Em maio, por exemplo, um imigrante chamado Vandewad se apresentou como representante dos colonos para reclamar que durante todo mês de abril não fora entregue a eles o suprimento de víveres. ${ }^{53}$ Alguns dias depois, o Presidente da Comissão comunicava o recebimento de outra reclamação, assinada por mais de trinta colonos, solicitando redução na quantia ou mudança de qualidade de produtos enviados regularmente como farinha de trigo e tabaco. ${ }^{54}$

Era comum a Comissão apresentar uma justificativa para suas decisões, embora existam situações em que ela apenas comunicava o pedido e o resultado do seu julgamento. No caso de uma solicitação de aumento na remessa de aguardente, por exemplo, seus membros recusaram, argumentando que o atendimento ao pedido podia dar lugar a "incovenietes resultados". Quando os pedidos dos colonos envolviam questões contratuais, transparecia toda a burocracia envolvida na instalação das

\footnotetext{
${ }^{49}$ COMISSÃO de Colonisação. Diario de Belém, 08/01/1876.

${ }^{50}$ COMISSÃO de Colonisação. Diario de Belém, 27/01/1876.

${ }^{51}$ COMISSÃO de Colonisação. Diario de Belém, 05/02/1876.

${ }^{52}$ COMISSÃO de Colonisação. Diario de Belém, 11/02/1876.

${ }^{53}$ [Sem Titulo].Diario de Belém, 16/05/1876.

${ }^{54}$ COMISSÃO de Colonização. Diário de Belém,12/05/1876.
} 
colônias. ${ }^{55}$ Afinal, depois de passar pelo diretor e pela Comissão, o pedido era enviado ao secretário da presidência, que o remetia para o secretário do Tesouro Provincial. ${ }^{56}$

O papel da Comissão era também o de resolver situações que não haviam sido previstas nos contratos. Em agosto, ${ }^{57}$ o colono Lambain Germano disse que por ter estado doente no hospital não pudera executar no seu lote os trabalhos que deveria ter feito. Prometendo voltar ao trabalho assim que se restabelecesse, o imigrante solicitou que a Comissão continuasse a fornecer os víveres que necessitava. ${ }^{58}$

Às vezes, as atas da Comissão deixavam transparecer que o diretor da colônia era alvo de pressões da parte dos colonos. Em uma oportunidade, registrou que os colonos haviam eleito uma comissão para solicitar do diretor algo para o qual não estava autorizado, ou seja, prorrogar o prazo de fornecimento de víveres. ${ }^{59}$ A resposta da Comissão a este pedido foi mais contundente do que em casos semelhantes, demonstrando haver alguma tensão nas relações entre os colonos e a direção do núcleo. Segundo ele, os colonos que faziam a reclamação já vinham sendo alimentados "à custa dos cofres provinciais" por espaço de 14 meses, não merecendo, portanto, uma nova prorrogação. ${ }^{60}$ No dia 22 de janeiro, os colonos Fluteau e Wasman apresentaram um projeto com a planta para criação de uma povoação na colônia. ${ }^{61}$ A Comissão, notando nesse pedido uma tentativa de criar uma colônia dentro da colônia, afirmou que se tratava de um desrespeito ao diretor de Benevies. ${ }^{62}$

Os insistentes pedidos de prorrogação do prazo de envio de víveres pareciam, às vezes, exasperar a Comissão de Colonização. Não pelo fato de a mesma encaminhar tais pedidos à Administração Provincial para que se pronunciasse, o que era sua função, mas pela maneira como os encaminhava, ou seja, com ressalvas de que se tratavam de pedidos injustificáveis. Os indeferimentos ocorriam independentemente do número de colonos que faziam a solicitação, o que demonstra que a Comissão não parecia estar suscetível às pressões. ${ }^{63}$

\footnotetext{
${ }^{55}$ RELATA a Comissão de Colonização. Diario de Belém, 13/07/1876.

${ }^{56}$ RELATA a Comissão de Colonização no dia 21 de julho. Diario de Belém,25/07/1876.

${ }^{57}$ [Sem Título]. Diario de Belém, 22/08/1876.

58 [Sem Título]. Diario de Belém, 22/08/1876.

59 RELATA a Commissão de Colonisação. Diario de Belém, 31/08/1876.

${ }^{60}$ RELATA a Commissão de Colonisação. Diario de Belém, 31/08/1876.

${ }^{61}$ COMISSÃO de Colonisação. Diario de Belém, 22/01/1876.

${ }^{62}$ COMISSÃO de Colonisação. Diario de Belém, 22/01/1876.

${ }^{63}$ RELATA a Commissão de Colonisação. Diario de Belém, 07/09/1876.
} 
Em um caso envolvendo colonos canadenses, a Comissão foi mais condescendente, deferindo o pedido com explicações detalhadas. $\mathrm{O}$ prazo estipulado no contrato para fornecimento de víveres expirara, mas os colonos não teriam tido tempo ainda para "tirar a sua manutenção". Isto porque ao chegarem ao Pará não puderam seguir imediatamente para a colônia, por causa de dificuldades no transporte de suas bagagens. Uma vez na colônia, receberam seus lotes na "força da estação invernosa", razão pela qual não os puderam trabalhar imediatamente. Ainda assim, a Comissão fez a ressalva de que a prorrogação do prazo de fornecimento de víveres só era válida para os colonos reclamantes que haviam dado provas de "espírito de trabalho" e que tivessem “efetivamente executado" os serviços que não dependiam das condições do tempo. ${ }^{64}$

Outro aspecto importante revelado pelas atas da Comissão de Colonização é a presença de colonos cearenses já em 1876, e não apenas a partir do ano seguinte, como por vezes é relatado nos relatórios presidenciais. ${ }^{65}$ Vários pedidos foram encaminhados por eles à Comissão, que os considerou da mesma maneira como tratava dos pedidos feitos pelos colonos estrangeiros.

Outro detalhe importante é que a Comissão também dava recomendações ao diretor do núcleo sobre a maneira como proceder diante de determinadas solicitações dos colonos. Em uma oportunidade, recomendou que não fornecesse víveres a colonos que, ausentando-se depois de receberem os víveres de um mês, só voltassem no mês seguinte para receberem um novo suprimento; nem fornecesse, também, àqueles cujos trabalhos "nulos ou insignificantes" indicassem ter sido feitos com o intuito de iludi-lo para obter as rações que devia distribuir. ${ }^{66}$ Outra recomendação era descontar as rações dos dias de ausência não participada ou não justificada com antecedência. Mais do que isso, recomendava que as rações fossem dadas apenas ao colono que desse prova de "amor ao trabalho e assídua aplicação a ele", sem procurar contemporizar. ${ }^{67}$

Mas não eram apenas rações e víveres que os colonos recebiam ou reivindicavam. No dia 22 de outubro de 1876, um grupo deles pediu sementes ou mudas de milho, arroz, algodão, urucum, maniva e cana. ${ }^{68}$ Mesmo informando que eles ainda não haviam recebido as sementes a que tinham direito, a Comissão encaminhou o

\footnotetext{
${ }^{64}$ RELATA a Commissão de Colonisação. Diario de Belém, 01/09/1876.

65 [Sem Título]. Diario de Belém, 12/11/1876.

${ }^{66}$ [Sem Título]. Diario de Belém, 06/12/1876.

${ }^{67}$ [Sem Título]. Diario de Belém, 06/12/1876.

${ }^{68}$ RELATA a Commissão de Colonisação. Diario de Belém, 22/10/1876.
} 
pedido à presidência da Província. Em uma ocasião, a Comissão comunicou haver recebido, talvez por engano, a solicitação de um colono de Santarém. Ele solicitava sementes de hortaliça e flores, galinhas e carneiros de criação, assim como alguns livros franceses para o ensino. ${ }^{69}$ A resposta a Comissão foi que ele se dirigisse à Comissão que cuidava dos assuntos da sua colônia. ${ }^{70}$

Os colonos de Benevides também pediram, por diversas vezes, aves para criação. ${ }^{71}$ Mesmo uma solicitação dessa tinha de ser encaminhada para o Presidente da Província, o que fez com que um pedido feito em março só obtivesse resposta em julho. $^{72}$ Casos assim demonstravam a excessiva centralização do sistema de administração da colônia, o que seria depois considerado como uma das causas do seu fracasso no que se refere à colonização estrangeira.

Além de galinhas para criação, os colonos pediam o fornecimento de gado vacum e de uma carapina para a construção de casas de telhas, ${ }^{73}$ sendo que este último foi indeferido por não constar no contrato. Outros pedidos eram registrados mas não obtinham resposta; ou eram recebidos e o colono informado que a Comissão os levaria para o Presidente da Província deliberar, pois não podia fazê-lo sem autorização dele. ${ }^{74}$ A morosidade era tanta que em uma oportunidade um colono, necessitando de um animal, foi até a cidade e o comprou com seus próprios recursos. ${ }^{75}$

Havia muitos pedidos de roupas e sapatos, ${ }^{76}$ mas também solicitação para montar na colônia uma fábrica de telhas. ${ }^{77}$ Nesse caso, a Comissão, autorizada pelo Presidente da Província, permitiu a instalação da fábrica, mas exigiu do colono um contrato conferindo à Administração Provincial controle estrito sobre a venda do produto. ${ }^{78}$ Após várias negociações, o colono desistiu do negócio e exigiu da Província uma indenização pelos gastos que fizera.

\footnotetext{
${ }^{69}$ RELATA a Commissão de Colonisação. Diario de Belém, 22/10/1876.

${ }^{70}$ RELATA a Commissão de Colonisação. Diario de Belém, 22/10/1876.

${ }^{71}$ COMISSÃO de Colonisação. Diario de Belém, 10/03/1876.

${ }^{72}$ COMISSÃO de Colonisação. Diario de Belém, 10/03/1876.

${ }^{73}$ COMISSÃO de Colonisação. Diario de Belém, 05/02/1876.

${ }^{74}$ COMISSÃO de Colonização. Diário de Belém, 12/05/1876.

75 [Sem Título]. Diario de Belém, 20/06/1876.

${ }^{76}$ COMISSÃO de Colonização. Diario de Belém, 18/03/1876.

${ }^{77}$ COMISSÃO de Colonisação. Diario de Belém, 09/03/1876.

${ }^{78}$ COMISSÃO de Colonização. Diario de Belém, 18/03/1876.
} 
Outra solicitação comum era auxílio para o transporte de produtos até o mercado de Belém. ${ }^{79}$ Estes pedidos geralmente eram acompanhados da justificativa de que o governo não construíra uma via de comunicação entre a colônia e a capital da Província, conforme previsto. Quando da sua inauguração, esperava-se que a projetada Estrada de Ferro de Belém a Bragança logo chegasse ao núcleo, mas isso só ocorreu em 1884. Aproveitando-se do problema de transportes, o colono Pierre Bechat enviou à Comissão uma proposta de fabricação de seirões - espécie de cestos para transporte de mercadorias em lombos de animais. ${ }^{80}$ Em junho de 1876, dois colonos apresentaram proposta para abertura de uma serraria. ${ }^{81}$ Já os colonos Emilie Lens e Victor Dan-Aort fundaram uma sociedade rural, cujos objetivos não foram esclarecidos pela Comissão.

Em outras ocasiões, os colonos exigiam adiantamentos e títulos provisórios dos lotes nos quais estavam instalados. ${ }^{82}$ Em uma ocasião, pelo menos, um pedido deste tipo foi encaminhado por suas esposas. ${ }^{83}$ Não obtendo títulos provisórios ou definitivos, nem por isso os colonos deixavam de permutar seus locais de moradia. Para isso, no entanto, também precisavam de autorização da presidência da Província. ${ }^{84}$

As atas da Comissão registraram reclamações quanto às remessas feitas por parentes do país de origem e não recebidas. ${ }^{85}$ Às vezes um pedido era feito de forma considerada imprópria pela Comissão. Um caso assim ocorreu no mês de outubro, quando a ata da Comissão registrou que o colono Victor Dan Aort, por si e outros companheiros, pedira, "em termos inconvenientes", o fornecimento dos animais domésticos e telhas, conforme estabelecido nos contratos, além da construção de estradas e pontes de que precisavam. ${ }^{86}$ Em resposta, a Comissão deliberou devolver a solicitação, por intermédio do diretor da colônia, pois o pedido estava redigido "em termos inconvenientes", não podendo, por isso, ser tomado em consideração. ${ }^{87}$ É possível que os termos usados estivessem relacionados com demandas anteriores, pois

\footnotetext{
${ }^{79}$ RELATORIO da Comissão de Colonisação. Diario de Belém, 26/04/1876.

${ }^{80}$ COMISSÃO de Colonisação. Diario de Belém, 20/04/1876.

${ }^{81}$ [Sem Titulo].Diario de Belém, 13/06/1876.

82 RELATO da Comissão de Colonização. Diário de Belém, 09/05/1876.

${ }^{83}$ RELATA a Comissão de Colonização no dia 21 de julho. Diario de Belém, 25/07/1876.

${ }^{84}$ COLONOS. Diario de Belém, 19/02/1876.

${ }^{85}$ COMISSÃO de Colonisação. Diario de Belém, 05/03/1876.

${ }^{86}$ RELATA a Commissão de Colonisação. Diario de Belém, 22/10/1876.

${ }^{87}$ RELATA a Commissão de Colonisação. Diario de Belém, 22/10/1876.
} 
alguns meses antes, ${ }^{88}$ Dan-Aort comunicou o furto de seus utensílios, solicitando a reposição dos mesmos, mas a Comissão indeferiu. ${ }^{89}$

Há um número considerável de pedidos de autorização ou auxílio para viagens e para transferência para outras regiões. Esses pedidos se intensificaram já em fins de 1876, sendo possivelmente um indício do descontentamento e da desilusão dos colonos com os rumos do núcleo. Em fevereiro, o colono Gouis solicitou à Comissão o adiantamento de três meses de suas rações e uma passagem para ir à Espanha buscar uma filha e outros parentes..$^{90} \mathrm{Na}$ mesma data, o colono José Gouis pediu à Comissão para ir ao mesmo país buscar uma filha e parentes, enquanto o colono Gustave Lary comunicou necessitar ir à França. ${ }^{91} \mathrm{O}$ colono Chalamel solicitou uma passagem para um irmão que estava na França. ${ }^{92}$ Já o colono Freguim François pediu que o governo lhe mandasse vir a mulher e filho, que estavam na França em casa de seu sogro. ${ }^{93}$

Ainda em fevereiro, o colono Antonio Simão solicitou à Comissão uma passagem para regressar para o Rio de Janeiro, ${ }^{94}$ mas o pedido foi indeferido. ${ }^{95} \mathrm{Da}$ mesma forma, seis emigrantes solicitaram passagem para o Sul. ${ }^{96}$ A Comissão não atendeu ao pedido e os colonos as solicitaram mais uma vez. ${ }^{97}$ Inexplicavelmente, o colono Pierre Angelo solicitou passagem para Manaus e obteve. ${ }^{98}$ Poucos dias depois, os colonos Florentino Gutierres, ${ }^{99}$ Ordone Ioanne e José Bianqui ${ }^{100}$ obtiveram passagens para a mesma cidade. Além destas há um grande número de solicitações feitas nos últimos meses de 1876.

Outro tipo de solicitação era o envio de cartas a parentes. As correspondências, da mesma forma que outras solicitações, tinham de passar pelas mãos do diretor para chegar à Comissão de Colonização, que as encaminhava para a presidência da Província. Só então seguiam seu destino. No dia 5 de março, por exemplo, a Comissão

\footnotetext{
${ }^{88}$ [Sem Título]. Diario de Belém, 22/08/1876.

${ }^{89}$ [Sem Título]. Diario de Belém, 22/08/1876.

${ }^{90}$ COMISSÃO de Colonisação. Diario de Belém, 11/02/1876.

${ }^{91}$ COMISSÃO de Colonização. Diario de Belém, 13/06/1876.

92 COMISSÃO de Colonisação. Diario de Belém, 19/02/1876.

${ }^{93}$ RELATA a Commissão de Colonisação. Diario de Belém, 22/10/1876.

${ }^{94}$ COMMISSÃO de Colonisação. Diario de Belém, 25/02/1876.

${ }^{95}$ COMMISSÃO de Colonisação. Diario de Belém, 09/03/1876.

${ }^{96}$ COMISSÃO de Colonisação. Diario de Belém, 19/03/1876.

${ }^{97}$ COMISSÃO de Colonisação. Diario de Belém, 19/03/1876.

${ }^{98}$ COMISSÃO de Colonisação. Diario de Belém, 01/04/1876.

${ }^{99}$ COMISSÃO de Colonisação. Diario de Belém, 20/04/1876.

${ }^{100}$ COMISSÃO de Colonisação. Diario de Belém, 12/04/1876.
} 
acusou o recebimento da carta que o colono Martim Celestim escrevera para sua mulher, que vivia na França. Uma semana depois a Comissão acusava um ofício da presidência da Província informando ter dado destino à carta. ${ }^{101}$

O pedido mais inusitado feito pelos colonos aconteceu no mês de fevereiro. Um grupo de colonos solteiros solicitou da Comissão que a Administração Provincial lhes arranjasse casamento. ${ }^{102}$ Em março o colono José Puertes solicitou à Comissão uma dispensa eclesiástica para casar-se com a viúva de outro colono. ${ }^{103}$ A resposta da Comissão, nesse caso, foi de que havia se entendido com o secretário do bispado a respeito do casamento. ${ }^{104}$ Em novembro, o colono Dury Eduard pediu licença para ir à França, a fim de fazer casar uma filha e tratar de negócios concernentes à sua familia. ${ }^{105}$

As atas da Comissão de Colonização revelam um imigrante muito diferente daquele geralmente idealizado pelos administradores e redatores de jornais. A partir de 1877, muitos dos que se referiram à tentativa fracassada de instalação de europeus em Benevides assinalaram que os colonos haviam sido mal recrutados, ou seja, que não seriam trabalhadores rurais. Esta avaliação talvez seja o resultado do desapontamento em relação ao que imaginavam ser a melhor alternativa para solucionar o problema da agricultura no Pará. O fato é que os imigrantes se revelaram excessivamente exigentes e questionadores. Solicitaram mais do que aquilo que estava estabelecido nos contratos e abandonaram o núcleo em pouco tempo.

\subsection{De onde virá a solução?}

A expectativa de que os cearenses resolveriam o problema de braços da agricultura do Pará parece ter sido desfeita logo no início da década de 1880. A julgarmos pelos relatórios e falas dos presidentes, parte considerável dos cearenses estava deixando os núcleos coloniais para se dedicar ao trabalho de extração da borracha ou retornando à sua Província de origem. De acordo com José Pedrosa, os

\footnotetext{
101 [Sem Título] Diario de Belém, 11/03/1876.

102 COMISSÃO de Colonisação. Diario de Belém, 11/02/1876.

${ }^{103}$ COMISSÃ̃ de Colonisação. Diario de Belém, 12/03/1876.

${ }^{104}$ COMISSÃO de Colonisação. Diario de Belém, 14/03/1876.

105 [Sem Título]. Diario de Belém, 12/11/1876.
} 
novos seringueiros estavam sendo atraídos por rendas "avultadas", porém efêmeras. ${ }^{106}$ A agricultura, segundo ele, era a fonte mais segura de riqueza, mas os cearenses pareciam não acreditar nisso. ${ }^{107} \mathrm{~A}$ alternativa seria, então, buscar braços fora da Província, mais afeitos à vida segura com o trabalho agrícola, ou seja, imigrantes europeus, pois a escravidão não era mais "bandeira de progresso". 108 Para tanto, solicitou que a Assembléia Provincial destinasse recursos para a fundação e apoio de novas colônias agrícolas. ${ }^{109}$

Entretanto, a situação da Província era grave, pois, segundo Justino Ferreira Carneiro, o fato de os cearenses se dedicarem à extração da borracha e não à agricultura começava a provocar escassez de alimentos. ${ }^{110}$ Tanto assim que vários produtos, cuja produção local, até então, era suficiente para o consumo, agora tinham de ser importados. Mais uma vez um Presidente lançava seus olhos para o mar, na esperança que a solução viesse do outro lado do Atlântico. Era preciso, segundo Justino Ferreira Carneiro, atrair "estrangeiros laboriosos", que se ligassem ao solo e não se deixassem seduzir pelo lucro fácil da exploração dos seringais. Esta esperança o obrigava, também, a lançar os olhos em direção ao Rio de Janeiro. A exemplo de outros administradores, ele afirmou que o Pará dava mais contribuições para os cofres públicos do que outras Províncias como Rio Grande do Sul, Santa Catarina, Paraná e Espírito Santo, merecendo, portanto, do Governo Imperial o mesmo apoio para a importação de trabalhadores imigrantes.

\footnotetext{
${ }^{106}$ Pará. Falla com que o exm. snr. Dr. João José Pedrosa abrio a $1^{a}$. sessão da $23^{a}$. legislativa da Assembléa Legislativa da Provincia do Pará, em 9 de abril de 1882. Belém: Typ. de Francisco da Costa Junior, 1882.

${ }^{107} \mathrm{Na}$ Fala com que abriu a sessão da Assembléia Provincial do Pará em 1882, o Presidente da Província João José Pedrosa anexou um estudo intitulado "Indústria Extractiva - a Borracha", no qual seu autor, M. A. Pimenta Bueno, afirmou que fora uma imprevidência o Pará e o Amazonas não incentivarem a agricultura. Segundo ele, nada prosperava naquelas províncias além da borracha e com esta apenas se beneficiavam o fisco e os intermediários, ficando a população - tapuios e cearenses fugidos das secas em estado lastimável. BUENO, M. A. Pimenta. "Industria extractiva - a Borracha. Considerações por...". In: Pará. Falla com que o exm.o snr. dr. João José Pedrosa abrio a 1.a sessão da 23.a legislatura da Assembléa Legislativa da provincia do Pará em 23 de abril de 1882. Pará, Typ. de Francisco da Costa Junior, 1882, Anexo. p. 47-62.

${ }^{108}$ Pará. Falla com que o exm. snr. Dr. João José Pedrosa abrio a $1^{a}$. sessão da $23^{a}$. legislativa da Assembléa Legislativa da Provincia do Pará, em 9 de abril de 1882. Belém: Typ. de Francisco da Costa Junior, 1882. p. 25-27.

${ }^{109}$ Ibidem. p. 14.

${ }^{110}$ Pará. Relatorio com que a sua exc. o sr. Dr. Justino Ferreira Carneiro passou a administração da provincia do Pará no dia 25 de agosto de 1882 o excmo. sr. Conselheiro João Rodrigues Chaves, $1^{o}$. Vice-Presidente da mesma Provincia. Belém: Typ. do Commercio do Pará, 1882. p. 19-21.
} 
Corroborando o ponto de vista de seu antecessor, o Visconde de Maracajú afirmou que a solução para o problema da alimentação pública na Província era a introdução de colonos estrangeiros "ativos e laboriosos", sendo necessário, portanto, oferecer-lhes "terras baratas e segurança individual." 111 Uma cláusula do contrato de construção da Estrada de Ferro de Belém a Bragança, aparentemente esquecida durante a euforia pela chegada dos cearenses, era agora relembrada. Ela estabelecia que dez mil colonos seriam introduzidos num período de quatro anos, juntamente com a construção de escolas e garantias de transporte para produtos agrícolas. ${ }^{112}$

Há duas mudanças significativas nos relatórios e falas produzidos no início da década de 1880 em relação àqueles elaborados nos anos 1870. Em primeiro lugar, os administradores registram com maior freqüência o engajamento dos trabalhadores cearenses nos trabalhos de extração do látex. Assim, quando se referiam à necessidade de incrementar a produção agrícola da Província, as expectativas passam a ser depositadas novamente nas possibilidades de importação de trabalhadores europeus. Por outro lado, aumentam os comentários sobre as crises da economia da borracha, assim como as avaliações negativas sobre o impacto dessa atividade no desenvolvimento da Província. O fato de o fluxo de cearenses em direção ao Pará ter retraído talvez seja a explicação para o fato de os Presidentes não cogitarem a possibilidade de um retorno às colônias por parte daqueles que as haviam abandonado pela miragem dos lucros da borracha.

Ao invés disso, aumentavam as críticas dos presidentes à chamada "indústria extrativa". Carlos Augusto de Carvalho, que administrou a Província em meados da década de 1880, por exemplo, afirmou que o movimento populacional causado pela extração da borracha fazia com que algumas povoações ficassem periodicamente desertas. ${ }^{113}$ Citando Herbert Spencer, argumentou que a organização das sociedades humanas obedecia a determinadas leis, mas que os habitantes do Pará não haviam desenvolvido aquelas capacidades indispensáveis à vida civilizada. O papel do Administrador seria, então, justamente facilitar essa "evolução natural”, promovendo

${ }^{111}$ Pará. Falla com que o exm. sr. General Visconde de Maracajú Presidente da Provincia do Pará, pretendia abrir a sessão extraordinaria da respectiva Assembléa no dia 7 de janeiro de 1884. Belém: Typ. do Diario de Noticias, 1884. p. 20.

${ }_{112}$ Ibidem. p. 92-93.

${ }^{113}$ Pará. Relatorio que ao exm. sr. dr. João Lourenço Paes de Souza $1^{o}$. Vice-Presidente da Provincia do Gram-Pará apresentou ao exm. sr. dr. Carlos Augusto de Carvalho, em 16 de setembro de 1885. Belém: Typ. de Francisco da Costa Junior, 1885. p.3. 
uma "conveniente distribuição e classificação da receita provincial" para os municípios. ${ }^{114}$ Outra medida a ser tomada, evidentemente, era a introdução de trabalhadores europeus, uma vez que os braços nacionais dificilmente poderiam ser aproveitados na agricultura em virtude da concorrência dos negócios da borracha. ${ }^{115}$

Está implícita nesse raciocínio a expectativa de que a extração do látex não atrairia o imigrante, o que o tornava preferível ao cearense quando se tratava de pensar no desenvolvimento da agricultura. Além disso, a crise nos negócios da borracha à qual os administradores se referiam eram uma baixa no preço do produto no mercado internacional, que não correspondia, necessariamente, a uma queda na produção interna. Os presidentes talvez soubessem que as crises no mercado internacional eram passageiras e que a uma retração seguir-se-ia uma nova fase de expansão.

Praticamente todos os presidentes que administraram o Pará reconheceram que a abertura de estradas de rodagem e ferrovias era uma condição necessária para o sucesso da colonização e da agricultura local. Esta percepção não era restrita aos governantes do Pará, pois nas demais províncias, solicitações de mais recursos para a abertura e manutenção das estradas eram freqüentes. Entretanto, numa Província de grande extensão, como era o caso do Pará, e com tantos obstáculos naturais, a abertura e manutenção de estradas era fundamental. Assim, para João Lourenço Paes de Souza, ${ }^{116}$ a viação terrestre possibilitaria a exploração dos vastos territórios entre os rios e o aproveitamento de, pelo menos, a "milésima parte das forças produtivas" da região, abrindo-a ao "trato civilizado". 117 As estradas, completou o Administrador, contribuiriam para o aproveitamento do solo, fixando a população erradia que percorria a Província em busca dos produtos extrativos. Além disso, possibilitaria a fixação de imigrantes europeus, mas para tanto era necessário fazer propaganda na Europa sobre as vantagens da Província. ${ }^{118}$

O sucessor de Paes de Souza, Tristão de Alencar Araripe, lembrou que a Estrada de Ferro de Bragança havia sido construída para incentivar a agricultura, mas

\footnotetext{
${ }^{114}$ Ibidem. p. 30-32.

${ }^{115}$ Ibidem. p. 111-112.

${ }^{116}$ Pará. Relatorio que ao exm. sr. conselheiro Tristão de Alencar Araripe apresentou o exm. sr. dr. João Lourenço Paes de Souza, $1^{\circ}$. Vice-Presidente da Provincia, ao passar-lhe a administração da mesma, em 5 de outubro de 1885. Belém: Typ. do Diario de Noticias, 1886, p. 3.

117 Ibidem. p. 6.

${ }^{118}$ Ibidem. p. 7-10.
} 
isto não vinha ocorrendo devido ao alto custo dos fretes. ${ }^{119}$ Assim, ao fundar a Associação Paraense de Imigração, ${ }^{120}$ o Presidente condicionou o desenvolvimento da imigração ao das comunicações, criticando, em seguida, a idéia de que o Brasil devia colonizar o Sul para que este colonizasse o Norte, em virtude das condições equatoriais serem adversas ao europeu. Afinal, a exemplo de outras regiões do país, o Norte havia sido colonizado por europeus, o que significava que o problema da imigração ali não residia nas suas condições naturais, mas na falta de investimentos por parte governo.

O Governo Imperial não enviou os recursos solicitados pelo Presidente para o desenvolvimento da agricultura, muito menos para o dos transportes. Em razão disso, Tristão de Alencar Araripe teria gastado recursos provinciais para instalar algumas famílias açorianas e quinze famílias escocesas na Província. ${ }^{121}$ A Sociedade Paraense de Imigração se encarregou do recebimento e alimentação desses colonos, que foram instalados às margens da Estrada de Ferro de Bragança, no lugar denominado Apehu, onde 30 lotes haviam sido demaracados e um barracão construído. ${ }^{122}$

Poucos meses depois, Joaquim da Costa Barradas, em meio a uma crise nos negócios da borracha, ${ }^{123}$ solicitava que os deputados provinciais mantivessem a verba destinada à imigração, "uma das maiores necessidades da Província”. Mas ao contrário de outros administradores, ele não apoiava o regime de colônias, pois, além de dispendioso, propiciaria o desenvolvimento apenas de algumas regiões, apesar de contribuir para o aumento população, do gosto pela lavoura, pela pecuária e por outras indústrias que demandavam a fixação das pessoas. Os núcleos Benevides e Apehú poderiam servir de "receptáculo provisório", para que os estrangeiros economizassem nos gastos. Quanto à colônia de Benevides, o Administrador afirmou que ela vinha

\footnotetext{
119 Ibidem. p. 11. Em 1889, Miguel José d’Almeida Pernambuco determinou a redução de $10 \%$ nas passagens da Estrada de Ferro de Bragança ara promover o povoamento da zona servida por ela. Pará. Falla com que o exm. snr. D. Miguel José d'Almeida Pernambuco, Presidente da Provincia, abrio a $2^{\mathrm{a}}$. sessão da $26^{\text {a }}$. legislatura da Assembléa Legislativa Provincial do Pará em 2 de fevereiro de 1889. Belém: Typ. de A. F. da Costa, 1889, p. 27.

${ }^{120}$ Ibidem. p. 82-84.

${ }^{121}$ Pará. Relatorio com que o Exm. Sr. Conselheiro Tristão de Alencar Araripe passou a administração da provincia ao Exm. Sr. Conselheiro João Antonio de Araujo Freitas Henriques em 15 de abril de 1886. Belém: Typ do Diario de Noticias, 1887.

${ }^{122}$ Ibidem. p. 6-7.

${ }^{123}$ Pará. Falla com que o Exm. Snr. Desembargador Joaquim da Costa Barradas abriu a sessão extraordinaria da Assembléa Legislativa Provincial do Pará em 20 de novembro de 1886. Belém: Typ. do Diario de Noticias, 1887, p. 6.
} 
desempenhando seus fins, havendo nela muitos colonos cearenses que cultivam o solo e ocupam-se com outras indústrias. ${ }^{124}$

Joaquim da Costa Barradas se referiu também a uma "Comunicação" enviada pela Sociedade Paraense de Imigração do Pará, datada de 15 de novembro de 1886, na qual esta associação informava que aplicara cem contos de réis recebidos da Assembléia Provincial na delimitação de lotes, construção de casas e um galpão às margens da Estrada de Ferro de Bragança. A mesma Sociedade teria recebido da presidência da Província o edifício dos Correios e recursos para abrigar e alimentar trinta famílias de agricultores recém-chegadas dos Açores.

Entretanto, apenas vinte e uma famílias teriam chegado a Belém, provenientes da Ilha da Madeira, e não dos Açores, as quais, transportadas para o núcleo Araripe, recusaram-se a desembarcar do trem. De acordo com Joaquim da Costa Barradas, esses imigrantes nada mais eram do que pessoas ignorantes, que acreditavam não ter o núcleo condições de recebê-las, apesar de as terras serem boas e a temperatura excelente. Tentou-se, então, estabelecer naquela colônia algumas famílias escocesas, mas a iniciativa também fracassou.

Surgiram, então, diferentes propostas para o povoamento do núcleo por nacionais ou estrangeiros. Entretanto, o Presidente da Província reconhecia a necessidade de serem feitos melhoramentos no local, o que não seria possível devido a falta de recursos. De acordo com o Administrador, a Sociedade de Imigração acha-se com boa vontade de ajudar a presidência no empenho de povoar o núcleo, porém recomendava o término das obras que restavam fazer no núcleo. ${ }^{125}$ A região amazônica, segundo ele, não devia gastar dinheiro público com ensaios de colonização, mas diligenciar para atrair imigrantes, dando a eles liberdade escolha. ${ }^{126}$ Havia no orçamento uma verba de cem contos para tal serviço, que deveria ser gasto com uma propaganda mais eficaz. ${ }^{127}$

A partir de 1886, com o advento da imigração em massa para São Paulo e o fracasso da maioria das inicitivas governamentais para introduzir colonos norte-

\footnotetext{
${ }^{124}$ Ibidem. p. 7-9.

125 Ibidem. p. 50-53.

126 Pará. Relatorio com que o Exm. Sr. Desembargador Joaquim da Costa Barradas passou a administração da província ao Exm. Sr. Conselheiro coronel Francisco José Cardoso Junior. Belém: Typ. do Diariode Noticias, 1887.

${ }^{127}$ Ibidem. p. 14-15.
} 
americanos e europeus no Pará, os administradores passaram a apoiar a "imigração espontânea" em detrimento da colonização. Joaquim da Costa Barradas, por exemplo, afirmou que os núcleos coloniais, além de dispendiosos, propiciavam o desenvolvimento apenas das regiões próximas a eles. ${ }^{128} \mathrm{O}$ melhor, segundo o Administrador, era realizar uma propaganda eficaz na Europa para atrair bons trabalhadores e dar a eles liberdade de escolha. ${ }^{129}$

Seguindo esta orientação, Francisco José Cardoso Junior conseguiu do Ministério dos Negócios da Agricultura, Comércio e Obras Públicas a promessa de subsídios para a acomodação e sustento de imigrantes até que fossem contratados por particulares. Além disso, entrou em contato com Frederico de Sant'Anna Nery, que se dirigiu para o Rio de Janeiro, a fim de se entender com o Governo Imperial, seguindo depois para a Europa. Na França, conversou com negociantes da praça de Bordéus, alugou um escritório para estabelecer uma agência central, tomou providências para a instalação de uma exposição permanente de produtos do Pará, confeccionou um "Guia do Imigrante", redigiu "notícias" e proferiu discursos com o intuito de atrair trabalhadores que pudessem emigrar para a Província. ${ }^{130}$

Todavia, a Assembléia Legislativa Provincial não aprovou o contrato entre a Presidência e Sant'Anna Nery. ${ }^{131}$ Francisco José Cardoso Junior ainda tentou firmar outro acordo, desta vez com Heraclio Vespasiano Fiock Romano, que ficou encarregado de introduzir na Província cinco mil imigrantes do Norte da Itália, Espanha ou Portugal. O contrato estabelecia que os trabalhadores deveriam ser "morigerados, sadios, robustos, mecânicos, artistas, operários, dados ao serviço da lavoura", de idade nunca excedente de quarenta e cinco anos, salvo se fossem chefes de família, constituindo estas pelo menos duas terças partes do número total. ${ }^{132}$

Estas qualidades tinham de ser atestadas pelos cônsules de cada país e o transporte, efetuado em navios de primeira classe. Além disso, Heraclio Romano ficava

\footnotetext{
${ }^{128}$ Pará. Falla com que o Exm. Snr. Desembargador Joaquim da Costa Barradas abriu a sessão extraordinaria da Assembléa Legislativa Provincial do Pará em 20 de novembro de 1886. Belém: Typ. do Diario de Noticias, 1887. p. 6.

129 Pará. Relatorio com que o Exm. Sr. Desembargador Joaquim da Costa Barradas passou a administração da Provincia ao Exm. Sr. Conselheiro coronel Francisco José Cardoso Junior. Belém: Typ. do Diariode Noticias, 1887. p. 14-15.

${ }^{130}$ Pará. Falla com que o exm. sr. conselheiro Francisco José Cardoso Junior, $1^{o}$. Vice-Presidente da Provincia do Pará, abrio a $1^{a}$. sessão da $26^{a}$. legislatura da Assembléa Provincial, no dia 4 de março de 1888. Belém: Typ. do Diario de Noticias, 1888. p. 18.

${ }^{131}$ Ibidem. p. 19-20.

${ }^{132}$ Ibidem. p. 26.
} 
encarregado de fazer propaganda das condições de emigração para a Província nos jornais e pela impressão e distribuição do "Guia do Immigrante", tendo de estabelecer agências na Itália, Espanha e Portugal. A emigração era livre e incondicional, sendo que o governo auxiliaria os que não se destinassem à agricultura apenas com a terça parte das passagens, desembarque e hospedagem de, no máximo, cinco dias. Os que quisessem se estabelecer nos núcleos coloniais teriam, além desses "favores", transporte até os lotes, casa provisória, instrumentos de lavoura, sementes e diárias de 450 réis por adulto e 250 réis por menor de oito anos, durante três meses. O contrato tinha validade até 31 de dezembro de 1889 e dependia da aprovação do Ministério da Agricultura. ${ }^{133}$

Mas o Governo Imperial não aprovou o contrato, devido a supostas irregularidades nos seus termos. ${ }^{134}$ Apesar disso, Miguel José d'Almeida Pernambuco preparou lotes para receber imigrantes açorianos, cuidando ainda do prolongamento da Estrada de Ferro de Bragança até o Apehú, com tarifa especial para transporte dos produtos da lavoura do Inhangapy. ${ }^{135}$ Mais uma vez, porém, uma área destinada à imigração européia era utilizada para abrigar imigrantes cearenses. Isto porque uma nova leva de retirantes chegava à Província em estado lamentável: famintos, doentes e maltrapilhos. Além de solicitar autorização do governo para abrir créditos com o objetivo de providenciar-lhes agasalho e socorro, o Presidente nomeou uma comissão para atendê-los nas suas reclamações, concedeu passagens aos interessados em se estabelecer no Amazonas, no interior ou nos núcleos Benevides, Santa Izabel, Araripe e Apehú. ${ }^{136}$ Determinou, ainda, que não seriam dados "socorros públicos" para os que se recusassem a trabalhar.

Outra medida que teria sido tomada pela presidência da Província fora a de firmar contratos para a instalação de famílias em terrenos situados às margens da ferrovia e na colônia militar de São João do Araguaya. ${ }^{137}$ Entretanto, José de Araújo

\footnotetext{
133 Ibidem. p. 18-28.

${ }^{134}$ Ibidem. p. 97.

${ }^{135}$ Pará. Falla com que o exm. snr. D. Miguel José d'Almeida Pernambuco, Presidente da Provincia, abrio a $2^{a}$. sessão da $26^{a}$. legislatura da Assembléa Legislativa Provincial do Pará em 2 de fevereiro de 1889. Belém: Typ. de A. F. da Costa, 1889, p. 84-85.

${ }^{136}$ Pará. Relatorio com que o exm. sr. dr. Miguel José d'Almeida Pernambuco, Presidente da Provincia do Pará, passou a administração da mesma ao Vice-Presidente da Provincia exm. senr. dr. João Polycarpo do Santos Campos, em 18 de maio de 1889. Belém: Typ. de A. Fructuoso da Costa, 1889. p. 53-54.

${ }^{137} \mathrm{O}$ contrato estipulava que aquela companhia se comprometia a um serviço regular de introdução de colonos europeus, sadios, morigerados e aptos para o serviço da agricultura naqueles locais supracitados. Além disso, devia construir uma hospedaria para recebê-los; colocá-los em lotes discriminados e garantir-
} 
Roso Danin teria visitado a região em que haviam sido instalados os cearenses, às margens da Estrada de Belém a Bragança, e tido a "desagradável impressão" de que as medidas não haviam beneficiado os trabalhadores ali estabelecidos. De acordo com o Administrador, convinha preparar os terrenos, demarcar os lotes, fornecer socorros para a construção de casas e alimentação, ao invés de encherem-se alojamentos com infelizes, consumindo, na ociosidade, os socorros do governo. ${ }^{138}$

Pouco antes do golpe militar que implantou o regime republicano no país, Antônio José Ferreira Braga afirmou que a Província necessitava adotar medidas para salvar-se do declínio em que ia caindo e da crise eminente de que estava ameaçada pelo decréscimo de suas rendas. ${ }^{139}$ A política imigratória havia sido dispendiosa e mal conduzida, não alcançando resultados satisfatórios. ${ }^{140}$ Quanto aos cearenses que se acumulavam em Belém, afirmou que providenciara a demarcação de lotes para a instalação de alguns deles nos núcleos Apehú e Benevides, encaminhara outros para municípios do interior da Província e para o Amazonas, sobretudo os interessados em se dedicar à lavoura, e até mesmo de volta ao Ceará. ${ }^{141}$

Em meados da década de 1880, eram constantes as referências dos administradores à crise da borracha. Mas suas preocupações não se limitavam à queda do valor do produto no mercado internacional. Carlos Augusto de Carvalho ${ }^{142}$, por exemplo, afirmou que o movimento populacional causado pela extração da borracha fazia com que algumas povoações ficassem, periodicamente, desertas. Baseando-se em Spencer, argumentou que as sociedades se desenvolviam e que, portanto, sua organização dependia de leis. No Pará, segundo ele, o homem não havia desenvolvido suas capacidades indispensáveis à vida civilizada. Entretanto, tal situação devia ser

lhes a subsistência e os utensílios de trabalho, enquanto dependessem da companhia. Esta devia informar ao Presidente da Província o número dos colonos colocados, seus lugares e cultura a qual se destinam, bem como indenizar o tesouro provincial das despesas com colonos que abandonassem seus lotes até dois anos após a data do seu estabelecimento. Ibidem. p. 64-77.

${ }^{138}$ Pará. Relatorio com que o exm. sr. dr. José de Araujo Roso Danin $1^{o}$. Vice-Presidente da Provincia do Pará passou a administração da mesma ao exm. sr. Dr. Antonio José Ferreira Braga. Belém: Typ. de A. Fructuoso Costa, 1889. p. 27 e ss.

${ }^{139}$ Pará. Relatorio com que o exm. sr. dr. Antonio José Ferreira Braga, Presidente da Provincia, abrio a sessão extraordinaria da $26^{a}$. legislatura da Assembléa Legislativa Provincial do Pará, em 18 de setembro de 1889. Belém: Typ. de A. Fructuoso da Costa, 1889. p. 4-5.

${ }^{140}$ Ibidem. p. 20.

141 Ibidem. p. 19-21.

${ }^{142}$ Pará. Relatorio que ao exm. sr. dr. João Lourenço Paes de Souza $1^{o}$. Vice-Presidente da Provincia do Gram-Pará apresentou ao exm. sr. dr. Carlos Augusto de Carvalho, em 16 de setembro de 1885. Belém: Typ. de Francisco da Costa Junior, 1885, p.3. 
mudada aos poucos e o papel do Administrador era justamente facilitar essa "evolução natural". ${ }^{143}$ Era necessário que houvesse uma distribuição e classificação mais conveniente da receita provincial para animar a vida local e não comprometer o "desenvolvimento da civilização". 144

Carlos Augusto de Carvalho, contrariando em parte seus antecessores, afirmou que apesar da queda dos preços da borracha a renda que o produto gerava não havia declinado, pois o aumento da quantidade exportada compensava a queda dos preços. ${ }^{145}$ Entretanto, no mesmo Relatório, o Inspetor do Tesouro Provincial reclamava providências para impedir o contrabando de borracha para Manaus. ${ }^{146}$ Sobre a colonização, o Presidente da Província reconheceu as dificuldades em promovê-la, mas argumentou que os braços nacionais dificilmente poderiam ser aproveitados na agricultura em virtude da concorrência dos negócios da borracha e que, portanto, o imigrante era indispensável. ${ }^{147}$ A catequese dos índios também poderia contribuir para a solução do problema da falta de braços, desde fosse iniciada na infância. ${ }^{148}$

Como atrair os trabalhadores de outras regiões ou países? De onde viriam? Para qual região seriam encaminhados? Em quais atividades seriam empregados? Estes eram apenas alguns dos pontos em discussão. $\mathrm{O}$ fato de os redatores reconhecerem que, ao contrário do que ocorria com as províncias cafeeiras, o Pará não dispunha de recursos suficientes para financiar uma imigração maciça, nem poder político para extrair do Governo Imperial as verbas necessárias para tanto, pouco contribuía para que chegassem a um consenso. Parte das dificuldades nesse sentido advinha do fato de a maioria deles estar ainda relutante sobre se a agricultura era o melhor meio de promover o desenvolvimento regional, sobretudo num momento em que a economia da borracha dava sinais de prosperidade.

Os negócios da borracha sofriam constantes flutuações devido à sua dependência em relação ao mercado internacional. Assim, era natural que os órgãos de imprensa oscilassem entre o pessimismo exagerado e o otimismo ufanista em relação ao progresso do Pará. Entretanto, os críticos do extrativismo geralmente consideravam

\footnotetext{
143 Ibidem. p. 30.

${ }^{144}$ Ibidem. p. 31-32.

145 Ibidem. p. 38.

${ }^{146}$ Ibidem. p. 45.

${ }^{147}$ Ibidem. p. 111-112.

${ }^{148}$ Ibidem. p. 112
} 
ilusória a prosperidade proporcionada pelos negócios da borracha, preconizando o apoio à agricultura e pecuária como forma de garantir um desenvolvimento mais consistente. O mais importante, contudo, é o fato de que estas alternativas dividiam as opiniões. Ou seja, praticamente todos os políticos e redatores de jornais dissociavam o extrativismo da agricultura. Raramente cogitavam a possibilidade de os lucros obtidos através das atividades extrativas fomentarem a produção de alimentos.

Diferentemente dos seus colegas do Diário de Notícias e de outros periódicos, o redator do Diário de Belém argumentava que a Província tinha poucas chances de progredir caso investisse na instalação de colônias agrícolas, fossem elas ocupadas por cearenses ou europeus. Em abril de 1886, procurando justificar este ponto de vista e sua opção pela imigração espontânea, ele transcreveu alguns trechos do Relatório do Presidente da Província do Paraná, Alfredo d'Escragnolle Taunay, sobre as supostas vantagens que a imigração teria em relação a colonização. De acordo com esta autoridade, que por sinal era correligionário político do redator do Diário de Belém e um dos políticos mais empenhados nessa questão, a imigração espontânea era preferível à colonização por que esta contribuía para a manutenção dos "traços primitivos" do imigrante - a sua língua, seus usos e costumes - dificultando a sua assimilação, a sua integração ao "espírito nacional", a "transfusão" do seu sangue na "comunhão nacional". 149

Estes aspectos, segundo o redator do jornal paraense, explicavam sua posição contrária ao que vinha sendo feito na Província com a instalação de trabalhadores europeus na colônia Benevides. Entretanto, ele acrescentou outras idéias às do Presidente da Província do Paraná, afirmando que nas colônias havia "favor demasiado" e isto criava a indolência em prejuízo do indivíduo e da coletividade. O homem, argumentava, nasce para a liberdade, cresce e se desenvolve pela iniciativa, mas "empalidece e diminui" no contato imediato com a "providência... administrativa". 150

O grande exemplo de como conduzir o problema da substituição do trabalho escravo pelo livre, de acordo com o redator, vinha da Província de São Paulo, que conseguia prosperar investindo recursos apenas no transporte de trabalhadores livres europeus e não na instalação de colônias agrícolas. Comparando os procedimentos das administrações provinciais de São Paulo e do Pará, ele apontou alguns problemas que

\footnotetext{
${ }^{149}$ [Sem título], Diário de Belém, 04/04/1886.

150 [Sem título], Diário de Belém, 04/04/1886.
} 
estariam dificultando a adoção da mesma política nesta última: tudo era "acanhado", "estreito" e "pequeno", porque tudo e todos estavam "dominados pelas considerações pessoais e ditados no interesse dos partidos e da capangagem". 151

Em outras oportunidades, no entanto, ao fazerem este tipo de comparação entre as duas Províncias, na tentativa de explicar as dificuldades que os paraenses encontravam na solução da "magna questão", os redatores dos jornais publicados em Belém atribuíam parte da responsabilidade ao Governo Imperial. Eles acusavam as autoridades de destinar os recursos disponíveis apenas para as províncias cafeeiras, em prejuízo daquelas que não possuíam uma riqueza agrícola equiparável.

Em diversas ocasiões, os redatores dos jornais afirmaram que o Pará não devia esperar qualquer ajuda do Governo Imperial. ${ }^{152}$ A solução para o problema do desenvolvimento regional estaria na própria Província, ou seja, os políticos deviam deixar de lado os interesses pessoais, as intrigas partidárias e se aliar à Administração Provincial para promover a importação de trabalhadores livres europeus. Nesse sentido, criticavam a Assembléia Legislativa Provincial por não adotar medidas necessárias ao estabelecimento de uma corrente imigratória considerável. Dela dependia o desenvolvimento e a grandeza do Vale Amazônico.

É evidente que os jornais, como porta-vozes de partidos políticos, tinham interesses em uma aliança entre os administradores e os deputados provinciais. Isto nos períodos em que seus respectivos partidos ocupavam as pastas ministeriais. Os redatores não ignoravam o fato de que os presidentes de província eram representantes do Governo Imperial e que dependiam da autorização dos legisladores para contratar agências de imigração. Tratava-se, ao que tudo indica, de um meio de pressionar os políticos a estabelecerem alianças a fim de solucionar o problema do suprimento de braços e do povoamento da Província.

Além do Diário de Notícias, o Diário de Belém também preconizava a união de todos na busca de soluções para os problemas que apontava como sendo os da Província. No entanto, ficava mais evidente no seu discurso a estratégia de apresentar como sendo da comunidade os interesses do partido ao qual estava vinculado e,

${ }^{151}$ Idem. Grifo no original.

152 Apesar das constantes reclamações da imprensa paraense nesse sentido, em 1886, o Diário de Belém informou que a Província receberia uma cota por conta da verba correspondente ao orçamento geral do império, destinada às províncias interessadas em facilitar a entrada de imigrantes. Ver: Diário de Belém, 19/03/1886. 
conseqüentemente, dos setores que esta agremiação representava. Isto porque, entre 1885 e 1889, tanto a redação do Diário de Belém como a Administração Provincial e a maioria dos deputados da Assembléia Legislativa eram constituídas por políticos do Partido Conservador.

Havia, contudo, além das disputas partidárias, outros obstáculos à imigração européia. Alguns deles eram levantados pela própria imprensa. Em meados de 1887, por exemplo, quando a Província de São Paulo já conseguia bons resultados com a imigração subvencionada de italianos, o Diário de Notícias divulgou um ofício enviado pelo cônsul brasileiro na Itália, oferecendo à Administração Provincial do Pará o estabelecimento de uma corrente imigratória para a região. Aproveitando-se da oportunidade, o redator do Diário de Notícias apresentou seus argumentos contra tal proposta: a imigração italiana ainda não teria "provado bem" em nosso país, pois o povo italiano "vivia mais do ideal do que do real", "alimentava-se mais da cabeça do que dos braços". Como prova disso, perguntava: em que se empregam os italianos chegados a Belém? Ou são mascates, ou tocadores de realejo, ou "carcamanhos", ou engraxates. Não se dedicavam à agricultura, apesar da existência de terras em abundância. ${ }^{153}$

Além desses fatores, o redator alegou que os imigrantes, contemplando o aspecto "severo" das matas e vendo meios mais fáceis de viver, abandonariam os lotes de terras que lhes fossem distribuídos e se atirariam à vida aventurosa de pequenos comerciantes de ruas e praias. Argumentava o redator do Diário de Notícias que os melhores colonos eram os alemães, por serem laboriosos, industriosos, sóbrios e sempre "artistas mais ou menos ilustrados", ${ }^{154}$ porém o Governo Provincial não estava em condições de subvencionar as passagens e sua instalação. Diante de tantos obstáculos, só restaria à Província esperar a imigração espontânea, atraída unicamente pela "liberalidade" das instituições brasileiras. Mas para isso era necessário que a escravatura, o maior obstáculo ao progresso do país, fosse extinta. ${ }^{155}$

Portanto, a imprensa contribuía, também, para manter viva na memória da população e das autoridades o fracasso das tentativas que haviam sido feitas no passado

\footnotetext{
${ }^{153}$ O POVOAMENTO. Diário de Notícias, 05/07/1887.

${ }^{154}$ Ao fazer estas considerações ele lembrou da experiência de Petrópolis, Teresópolis, Friburgo e Nova Friburgo, mas afastou as esperanças, afirmando que naquela região eles haviam se adaptado bem ao clima, o que não se daria na Amazônia.

155 Estas questões provocaram grande debate na imprensa de Belém. Ver: [Sem título], Diário de Notícias, 10/07/1887, "Pelo jornalismo.."
} 
para a introdução de imigrantes europeus. Muitas vezes, reforçavam essa memória transcrevendo, de outros periódicos, experiências igualmente mal sucedidas no país e no exterior. Quando se referiam às experiências bem sucedidas em outras regiões, tinham como objetivo assinalar a inexistência, no Vale Amazônico, daquelas condições que teriam garantido o sucesso em outras áreas, como as condições naturais satisfatórias e o apoio do governo. Assim, a duplicidade do conteúdo jornalístico, ou seja, a alternância entre sua abrangência mais extensa e seu localismo particularista adquiria um caráter mais profundo, articulando não apenas os lugares, mas também o passado e o presente na defesa de interesses específicos.

Esses interesses podiam ser tanto de partidos como de facções políticas ou mesmo de grupos sem vinculação partidária. Em meados de 1887, por exemplo, o Diário de Belém e o Diário do Gram-Pará, ambos vinculados à situação conservadora, estavam divididos: o primeiro apoiava a instalação de colônias agrícolas, constituídas preferencialmente por imigrantes europeus, enquanto o segundo recomendava o apoio ao extrativismo e se mostrava céptico quanto à viabilidade de se estabelecer uma corrente imigratória para a Amazônia. No mesmo período, o jornal A Província do Pará, cujos redatores e proprietários pertenciam à oposição liberal, não poupava crítica aos conservadores pelo fato de tentarem estabelecer colônias de imigrantes em Bragança, e não em Benevides. ${ }^{156}$ Insinuavam, assim, que esta decisão estaria sendo motivada por interesses escusos, mais precisamente o estabelecimento de núcleos coloniais e a construção de estradas de ferro nas proximidades ou em áreas que pertenciam a lideranças políticas e a seus aliados.

Em julho daquele ano, num artigo editorial intitulado "Povoamento", o redator do Diário de Notícias procurou mais uma vez esclarecer sua posição acerca da imigração européia, afirmando que não era propriamente "avesso" à idéia, mas que se pronunciava contra tal alternativa em vista dos precedentes: "só tem servido para tirar dinheiro dos cofres públicos; e nos dar um resultado completamente negativo daquele

\footnotetext{
${ }^{156}$ Diante do fracasso das tentativas de introdução de imigrantes estrangeiros na Colônia Benevides, passou-se a aventar a possibilidade de instalação de colonos nas margens da estrada de ferro que ligava Belém à cidade de Bragança. Várias propostas foram apresentadas e discutidas, porém somente na década de 1890 é que os colonos começaram a ser efetivamente instalados. Novas dificuldades surgiram, entre elas uma epidemia de varíola, provocando mais uma vez o abandono dos estabelecimentos coloniais por parte dos trabalhadores. Ver: CRUZ, Ernesto. Colonização do Pará. Op. cit., p. 77-81.
} 
que se esperava". ${ }^{157}$ Referindo-se a duas tentativas de introdução de imigrantes europeus na Província, ele argumentou que se tratava de uma "chusma de maltrapilhos, vadios, larápios e assassinos, o verdadeiro lixo das cidades da Europa". ${ }^{158}$ Tais imigrantes teriam abandonado a colônia e procurado as margens das estradas e a capital, vivendo na mais completa ociosidade e praticando roubos.

O sucesso da imigração italiana na Argentina, de acordo com o redator, explicava-se pelas condições naturais daquele país, que não possuía florestas grandiosas nem rios tão caudalosos como a Amazônia, nem um clima tão diferente do europeu. Quanto às províncias do Sul do Império, a prosperidade que ali se observava era devida aos negros, que enfrentavam qualquer tipo de serviço, nas condições mais adversas. Concluindo seu raciocínio, o redator afirmou que a Administração Provincial deveria envidar esforços para proporcionar meios de trabalho aos brasileiros, dando-lhes terra e instrumentos para lavrar. Tal política, segundo ele, teria um resultado mais pronto e eficaz, contribuindo ainda para que as famílias que "vegetavam na pobreza e isolamento, trabalhando como nômades em terrenos pantanosos", pudessem trocar a atividade extrativa pela agrícola. ${ }^{159}$

Em suma, as divergências entre o Diário de Notícias e o Diário de Belém acerca da colonização e da imigração indicam pelo menos duas maneiras diferentes de se encarar algumas das questões suscitadas pelo encaminhamento da emancipação da escravatura. Elas não eram as únicas, pois os redatores do Diário do Gram-Pará, ainda que pertencessem à mesma agremiação política em que militavam os redatores e proprietários daquele último, não apoiavam a colonização européia nem mesmo o favorecimento da agricultura em detrimento das atividades extrativistas. ${ }^{160}$ Estas posições, no entanto, não eram definitivas, uma vez que, a exemplo do que ocorreu com o Diário de Belém, que inicialmente apoiava a colonização e depois passou a defender a imigração, os jornais podiam mudar uma ou mais vezes de orientação.

Deve-se ressaltar, contudo, a diversificação das propostas apresentadas pelos redatores de jornais com vistas à transição do trabalho escravo para o trabalho livre e sua esperança no sentido de que as autoridades conseguissem vencer os obstáculos para

\footnotetext{
${ }^{157}$ O POVOAMENTO, Diário de Notícias, 12/07/1887.

158 Idem

${ }^{159}$ Idem

${ }^{160}$ WEINSTEIN, Barbara. Op. cit., p. 125.
} 
a definição de uma política de mão-de-obra. Em vista disso, torna-se relevante assinalar as recomendações dadas por alguns redatores às autoridades para que realizassem um bom recrutamento de braços nos países de origem, afastando a possibilidade de serem contratados elementos indesejáveis, assim como a preocupação que eles demonstravam com a adaptação destes trabalhadores às condições naturais da região e a sua instalação em locais onde pudessem desfrutar de terras férteis e de uma boa infra-estrutura de transporte. Tudo isto revela que, a despeito das divergências internas, a elite paraense estava ciente das experiências acumuladas na Província e daquelas em outras regiões do país.

Analisando a emigração de cearenses para fazendas de café de São Paulo em 1878, Denise Aparecida Soares de Moura observou que nem sempre este fenômeno esteve ligado aos interesses das elites e autoridades provinciais, pois se dava também em função de ajustes ligados a solidariedades vicinais, às formas de sociabilidade na terra natal, à afetividade e vínculo familiar e às relações de dependência. ${ }^{161} \mathrm{O}$ mesmo pode ser dito em relação à Amazônia, porém os jornais indicam que em muitos casos as solidariedades, sociabilidades, afetividades e relações de dependência entre os trabalhadores foi amplamente estimulada pelas elites e autoridades provinciais.

Artigos e notícias publicadas no jornal A Constituição deixam isso muito claro. Em 1877, este jornal divulgou cartas trocadas entre imigrantes cearenses estabelecidos no Pará e familiares e amigos que haviam permanecido na sua terra natal, como forma de estimular as elites paraenses a financiar a viagem daqueles que não tinham recursos para emigrarem. ${ }^{162}$ Nestes artigos, os redatores frisavam sempre as qualidades morais e a aptidão dos cearenses para o trabalho, ao mesmo tempo em que exaltavam as condições naturais da Amazônia. Além disso, acenavam com a possibilidade de o Governo Provincial resolver o problema do povoamento da região e da transição para o trabalho livre com recursos muito mais modestos do que aqueles que poderiam ser empregados na promoção da imigração européia.

\footnotetext{
${ }^{161}$ MOURA, Denise Aparecida Soares de. "Andantes de Novos Rumos: a vinda de migrantes cearenses para fazendas de café paulistas em 1878. Revista Brasileira de História, São Paulo, 17 (34): 119-132, 1997, p. 124.

${ }^{162}$ Veja-se, a título de exemplo, os seguintes artigos e notícias: "A miséria no Ceará", A Constituição, 07/06/1877, [seção] Gazetilha; "Os immigrantes cearenses no Pará", A Constituição, 14/06/1877, [seção Editorial]; “Auxilio aos Emigrados”, A Constituição, 11/06/1877, [seção] Gazetilha.
} 


\subsection{Conflitos regionais}

Em 1886, a imprensa de Belém publicou uma série de artigos sobre a criação da Sociedade Paraense de Imigração. Esta associação, fundada em 17 de novembro de 1885, tinha por objetivo promover a introdução de trabalhadores livres europeus no Pará. Concebida pelo Presidente da Província, Tristão de Alencar Araripe, nos moldes das que existiam em São Paulo e no Rio de Janeiro, aquela associação reuniu, no ato de sua instalação, além do próprio Administrador provincial, o Senador Gomes do Amaral e o bispo Antônio de Macedo Costa, este último muito conhecido por sua oposição a propostas daquela natureza. ${ }^{163}$

A criação de uma instituição com tais propósitos era naturalmente polêmica, visto que nem todos concordavam que se tratava da melhor alternativa de para resolver o problema do suprimento de braços para a região. ${ }^{164}$ Além do mais, para que esta associação pudesse funcionar era preciso que os seus estatutos fossem aprovados pela Assembléia Legislativa Provincial, onde havia muitos representantes dos grupos envolvidos com os negócios da borracha. Tais políticos poderiam estar interessados em canalizar os recursos que seriam destinados à Sociedade de Imigração para o fomento das atividades extrativistas, dificultando assim a sua criação.

De acordo com Ernesto Cruz, ${ }^{165}$ o tema dominante na sessão de instalação da Sociedade foi a colonização com imigrantes europeus, sendo esta a alternativa escolhida

\footnotetext{
${ }^{163}$ De acordo com David Gueiros Vieira, o Bispo D. Macedo Costa promoveu intensa campanha contra a presença de imigrantes confederados na Amazônia, chegando inclusive a patrocinar a fundação de uma Sociedade de Imigração Polonesa, em Belém, com o intuito de inviabilizar um suposto projeto dos liberais de "protestantizar" o Brasil. O bispo notabilizou-se ainda pela oposição obstinada contra os Presidentes da Província que pretendiam colocar em prática uma política imigratória, chegando inclusive a endereçar cartas ao Imperador, pedindo o afastamento dos mesmos. Ver: VIEIRA, David Gueiros. $O$ Protestantismo, a Maçonaria e a Questão Religiosa no Brasil. 2a. ed., Brasília: Editora UNB, s.d., p. 299-306.

${ }^{164}$ Na solenidade de criação da Sociedade Paraense de Imigração discutiu-se de qual deveria ser a origem dos trabalhadores a serem instalados na Província e a escolha recaiu sobre os europeus. De acordo com Karla Denise Martins, o bispo D. Macedo Costa não era propriamente contrário à imigração, mas à introdução de pessoas oriundas de países de religião protestante. Sua ação frente à diocese de Belém se baseava numa retomada do trabalho jesuítico no Vale Amazônico de modo a promover a integração dos povos que ali habitavam por meio do catolicismo romano. Esta integração visava à construção de uma sociedade que não seria regida pelos valores liberais, muitos deles associados ao protestantismo, como a vinculação entre o trabalho e a acumulação de riquezas. Em suma, o desenvolvimento regional não devia reproduzir aquele das sociedades industriais européias. MARTINS, Karla Denise. A Civilização Católica: D. Macedo Costa e o desenvolvimento da Amazônia na segunda metade do século XIX. Revista de História Regional. Ponta Grossa (PR), 7 (1): 73-103, 2002. Ver também CRUZ, Ernesto. Op. cit., p. 71. ${ }^{165}$ CRUZ, Ernesto. Op. cit. p. 71.
} 
pela maioria como melhor alternativa para promover o desenvolvimento da Província. Aos colonos seriam distribuídas terras sem ônus algum, com a concessão de título definitivo, passagens, alimentação, instrumentos aratórios e sementes. Receberiam também uma planta da colônia Benevides, com a indicação das terras devolutas, demarcadas e preparadas com todas as indicações úteis.

Como órgão vinculado à situação, o Diário de Belém tratou logo de enfatizar a importância da iniciativa. Para o redator deste jornal, a associação teria como finalidade acomodar os imigrantes recém-chegados, aconselhá-los e assisti-los com sua proteção, defender seus interesses e manter viva e assídua propaganda nos países em que havia braços disponíveis. ${ }^{166}$ Aproveitando a ocasião, ele insistiu também na importância de serem construídas mais estradas de ferro na região, a fim de auxiliar a instalação dos imigrantes no interior e facilitar o escoamento da sua produção. ${ }^{167}$ Havia, contudo, alguns obstáculos a serem vencidos, entre eles o abandono da Província por parte do Governo Imperial. ${ }^{168}$

As rivalidades entre o Norte e Sul do Império, geralmente expressas de forma mais explícita nos artigos de jornais, serviam naquele momento de pretexto para se conseguir o apoio das lideranças locais para aquela iniciativa da Administração Provincial. A idéia de que o Norte havia sido esquecido pelo Governo Imperial, precisando, portanto, cuidar sozinho dos seus interesses, procurava dar sentido às propostas de reformas discutidas pelos grupos políticos regionais em meio ao processo de abolição da escravatura e de reorganização do mercado de trabalho livre. ${ }^{169}$

A representação da Amazônia como uma região abandonada pelo Governo Imperial e, portanto, inferiorizada diante das províncias do Sul, desempenhava função semelhante às de prosperidade ou decadência, produzidas em relação ao Nordeste, Vale do Paraíba e Oeste Paulista. Estas representações faziam parte de uma estratégia política mais ampla, cujo objetivo era tentar extrair mais recursos do Governo Imperial e manter o processo de reorganização do mercado de trabalho dentro dos parâmetros aceitáveis pelos proprietários e demais setores da elite regional. Na verdade, em todas as regiões

\footnotetext{
166 [Sem título], Diário de Belém, 31/01/1886.

167 Idem.

168 [Sem título], Diário de Belém, 24/01/1886.

${ }^{169}$ Sobre o impacto das rivalidades entre o Norte e o Sul nos debates legislativos, mais especificamente em torno da questão do tráfico interprovincial de escravos ver: MELLO, Evaldo Cabral de. "O Norte, o Sul e a proibição do tráfico interprovincial de escravos”. In: O Norte Agrário e o Império. 1871-1889. 2ª . ed., Rio de Janeiro: Topbooks, s.d.
} 
do país as elites políticas reclamavam recursos junto às autoridades governamentais, geralmente alegando o escoamento da riqueza ali gerada para financiar $o$ desenvolvimento de outras áreas. Mas em nenhuma delas a imagem de abandono e esquecimento parecia tão convincente como a região do Vale Amazônico. ${ }^{170}$

A substituição do Presidente da Província responsável pela fundação da Sociedade Paraense de Imigração, que acabou sendo eleito deputado pelo Ceará, tornouse motivo de preocupação por parte dos que apoiavam a proposta. Isto porque os estatutos da associação ainda não haviam sido aprovados pela Assembléia Legislativa e uma troca de administradores poderia fazer com que a associação não se constituísse. $O$ redator do Diário de Belém lamentou o fato, argumentando que as mudanças sucessivas e repentinas nas administrações provinciais e gabinetes ministeriais eram as principais causas do atraso do país. Mal se organizava um ministério, já outro o substituía, o mesmo ocorrendo com os presidentes de província, que muitas vezes deixavam o cargo antes de tomar conhecimento dos seus negócios, das suas dificuldades e potencialidades humanas e materiais.

Dessa forma, todos trabalhavam, segundo ele, em um "círculo vicioso", fazendo, remendando, desmanchando e gastando sempre em pura perda de tempo e dinheiro. ${ }^{171}$ Para agravar esta situação os presidentes de província eram, na maioria das vezes, oriundos de outras regiões, que nada ou quase nada conheciam sobre aquelas que deviam administrar.

A idéia de que havia uma disputa entre o Norte e o Sul do Império pode ser percebida até mesmo na preferência que alguns redatores de jornais manifestavam a respeito da nacionalidade dos futuros trabalhadores, ou seja, da Alemanha e do Tirol. Enquanto alguns elegiam as condições naturais da Província como principal obstáculo à imigração, outros afirmavam justamente o contrário, defendendo a importação de trabalhadores das regiões de clima frio. ${ }^{172}$ Tratava-se, de acordo com um articulista do Diário de Belém, de mostrar ao Sul que o Norte tinha as mesmas chances de atrair braços oriundos da Europa, que viessem contribuir para a prosperidade da região. Em

\footnotetext{
${ }^{170}$ De acordo com Evaldo Cabral de Melo, em 1888, ao aludir aos "vastos horizontes da Amazônia", o deputado paraense Mâncio Ribeiro foi interpelado por um representante de Minas Gerais, que indagou: "onde é essa Amazônia de que o nobre deputado tanto tem falado"? MELO, Evaldo Cabral de. Op. cit., p. 15.

${ }^{171}$ [Sem título], Diário de Belém, 24/01/1886.

${ }^{172}$ [Sem título], Diário de Belém, 30/01/1886.
} 
algumas oportunidades, porém, tais rivalidades se transformavam em ameaças separatistas. ${ }^{173}$

O equilíbrio entre o Sul e o Norte do Império seria alcançado, então, com o desenvolvimento da agricultura desta última região. Os redatores de jornais repetiam insistentemente que a imigração era a principal necessidade da Província do Pará. Bastava que o Governo não criasse os "embaraços propositais", no intuito de atrair para o Sul os braços europeus, e que destinasse ao Norte parte do que enviava àquela região, para ficar provado que o europeu se adaptava perfeitamente à zona equatorial. Aliás, isto já estaria provado, uma vez que os portugueses haviam povoado a Amazônia e os franceses, Caiena. $^{174}$

Além disso, os redatores argumentavam que os recursos que estavam solicitando para a Província não eram auxílios, mas uma pequena parte do que ela merecia pela contribuição que enviava aos cofres da nação em razão das exportações de borracha e outros produtos extraídos da floresta amazônica. ${ }^{175}$ Em outras palavras, promover o povoamento da Amazônia era promover a grandeza do próprio Império, uma vez que mais recursos seriam arrecadados na forma de impostos. Com a imigração e os incentivos à agricultura, o desenvolvimento da região se daria de forma mais equilibrada, uma vez que as atividades extrativistas faziam prosperar apenas as áreas portuárias. Dessa forma, parte das críticas dos redatores empenhados em promover a imigração eram dirigidas aos setores envolvidos com os negócios da borracha. ${ }^{176}$

Respondendo aos que criticavam a instalação de imigrantes europeus em Benevides, com o argumento de que o solo daquele local não era ideal para o cultivo de gêneros agrícolas exportáveis, o redator do Diário de Belém afirmou que a "sementeira" já estava plantada e que haveria de crescer e proteger a Amazônia com sua sombra, provando, afinal, a compatibilidade do local com o braço europeu. A imigração, segundo ele, era uma tarefa árdua que não se completaria em dias ou meses. ${ }^{177} \mathrm{O}$ tempo se encarregaria de mostrar que o redator estava equivocado. A "sementeira" à qual se referia não frutificou; outra foi plantada em seu lugar, a começar por Benevides.

\footnotetext{
173 "Os que querem a integridade do paiz devem pensar seriamente no concurso que ao sul prestam os cofres geraes da nação, e o faz caminhar rapidamente com manifesto prejuizo para o equilibrio nacional". [Sem título], Diário de Belém, 31/01/1886.

${ }_{174}$ [Sem título], Diário de Belém, 21/03/1886.

${ }^{175}$ [Sem título], Diário de Belém, 19/03/1886.

176 [Sem título], Diário de Belém, 23/03/1886.

${ }^{177}$ [Sem título], Diário de Belém, 11/04/1886.
} 
Todavia, os migrantes cearenses foram absorvidos, em sua grande maioria, pelos negócios da borracha.

Algumas décadas mais tarde, o historiador Arthur Cezar Ferreira Reis utilizaria uma metáfora semelhante à do redator do Diário de Belém, mas para explicar o papel da Amazônia na formação da identidade nacional. ${ }^{178}$ A conquista do Vale Amazônico, segundo ele, era obra de um "punhado de bravos", os luso-brasileiros, que para ali haviam levado a "seiva cívica do Nordeste", empurrando a fronteira marcada em Tordesilhas. Da foz do grande rio, esta "seiva" se "irradiaria" para o interior da Amazônia e outras áreas do país. Em termos históricos, o autor se referiu à expulsão dos holandeses e outros estrangeiros do litoral do Nordeste e do Norte, evento transformado pela nascente historiografia brasileira em mito fundador da nacionalidade.

Entretanto, considerando-se que Arthur Reis escrevia num momento em que novas e significativas levas de migrantes nordestinos chegavam à Amazônia, não é improvável que estabelecesse um paralelo entre ambos os processos históricos. O mais importante, contudo, é que sua metáfora excluía os estrangeiros, com exceção do português, da “comunhão nacional”. Além disso, invertia o curso do processo histórico de nossa formação nacional, mais precisamente o curso consagrado pela historiografia da região Centro-Sul, que elegeu os bandeirantes, e não os luso-brasileiros que teriam expulsado os estrangeiros do litoral do Norte e Nordeste, como responsáveis pela consolidação das fronteiras do Brasil.

Nesta substituição de mitos fundadores pode estar a chave para explicação do fracasso das tentativas de imigração estrangeira no Pará e de seu sucesso em São Paulo. A ênfase de Arthur Reis nas ligações históricas entre o Norte e o Nordeste é reveladora do imaginário de parte substancial das elites daquela região acerca do imigrante. Imaginário este que associava o imigrante do século XIX aos aventureiros do passado colonial, movidos pela cobiça e desejo de riqueza fácil, e que a campanha em prol da imigração européia não conseguiu modificar.

Já em São Paulo, por razões históricas, ou seja, o fato de não se tratar de uma região que se forjou na luta contra o estrangeiro, o imigrante podia ser incorporado de forma menos problemática. Não por acaso, muitas das qualidades que a campanha imigrantista paulista investiu no trabalhador estrangeiro eram idênticas ou semelhantes

178 REIS, Arthur Cezar Ferreira. Limites e Demarcações na Amazônia Brasileira. Edição facsimilar, Belém: Secult, 1993, vol. I: “A Fronteira Colonial com a Guiana Francesa”, p. 58. 
às que haviam sido atribuídas aos bandeirantes e até mesmo aos cafeicultores. Isto não significa que estas imagens não tenham sofrido ajustes nem que a adaptação do imigrante à nova terra tenha sido tranqüila.

Apesar de ter sido sócio atuante do Instituto Histórico e Geográfico Brasileiro, Arthur Cézar Ferreira Reis não comungava do mesmo princípio abraçado pela maioria dos que integraram a instituição, ou seja, a defesa do liberalismo como matriz de pensamento a partir da qual se deveria erigir a nação civilizada. Nesse sentido, afastouse de uma interpretação do passado brasileiro, formulada a partir da Europa, aproximando-se em vários pontos das teses luso-tropicalistas de Gilberto Freire, mais especificamente o esforço no sentido de elevar o mestiço da condição de excrescência para a de elemento associado e, portanto, positivo na formação da identidade nacional. O elogio da mestiçagem, localizando no período colonial o ponto de partida de nossa formação nacional, deixava o imigrante que aqui aportou a partir do século XIX à margem dessa comunidade imaginada. Não foi, então, por acaso que tal ideologia, concebida em Pernambuco, encontrou ressonância na Amazônica e resistência em São Paulo.

\section{$3.5 \mathrm{O}$ duro choque da realidade}

A partir de 1871, principalmente, a perspectiva da proximidade do fim da escravidão provocou um intenso debate acerca das relações de trabalho, da propriedade e do uso da terra no Brasil. Várias propostas foram discutidas, muitas delas aprovadas e executadas, com vistas à substituição do escravo pelo imigrante europeu ou asiático. Cogitava-se, também, a possibilidade de os brasileiros pobres ocuparem um espaço mais significativo no mercado de trabalho, juntamente com os escravos que fossem adquirindo a liberdade, o que se efetivaria através da fundação de escolas práticas de agricultura e a aprovação de leis que reprimissem o ócio e a vadiagem. Nos momentos mais dramáticos, quando a sobrevivência do latifúndio sem o braço escravo chegou a ser posta em dúvida, discutiu-se até mesmo a adoção de incentivos à pequena lavoura e mecanismos para facilitar o acesso à posse terra.

Durante a década de 1880, à medida que se intensificava a pressão abolicionista, algumas propostas de médio e longo prazo, como aquelas relacionadas 
com o aproveitamento dos braços livres disponíveis por meio da educação ou da “catequese e civilização", passaram a dar lugar a outras de caráter mais imediato. Nesse sentido, duas alternativas não excludentes acabaram sendo privilegiadas: a colonização e a imigração. Esta última, contudo, era a preferida pela maioria dos que participavam dos debates, sobretudo se fosse subvencionada pelo Estado. Tal opção decorria não apenas do fracasso de várias tentativas colonizadoras que haviam sido feitas anteriormente, mas, sobretudo, porque oferecia a perspectiva de promover um aumento imediato da oferta de mão-de-obra assalariada. ${ }^{179}$

No Pará a situação era um pouco diferente. Conscientes da pouca expressividade numérica da população escrava local, quando comparada com a dos principais centros econômicos do Império, ${ }^{180}$ mas convencidos da dependência das atividades agrícolas locais em relação a uma fonte estável de suprimento de mão-deobra, redatores de jornais e presidentes da Província vislumbravam a possibilidade de atrair para núcleos coloniais próximos a Belém parte da corrente imigratória que se dirigia para outras áreas. Acreditavam que, incrementando o processo de povoamento da região, por meio de um conjunto de políticas públicas que não se limitasse à introdução de braços livres, poderiam finalmente concretizar um sonho acalentado desde os tempos coloniais: o de construir na Amazônia uma "civilização" equiparável à exuberância de sua natureza.

A análise de jornais, relatórios e falas dos presidentes de província evidenciam que as expectativas oscilavam num ritmo muitas vezes próximo ao das flutuações do preço da borracha no mercado internacional. Assim, por exemplo, quando os preços da borracha estavam em queda, aumentavam as críticas ao extrativismo e os pedidos de apoio à agricultura. Nesses momentos, o imigrante europeu e o cearense surgiam como uma espécie de "salvadores da pátria", pois se projetava neles tudo o que se esperava ou se desejava do trabalhador capaz de promover o progresso e a civilização. Quando os preços da borracha aumentavam, cresciam, na mesma intensidade, as críticas ao

\footnotetext{
${ }^{179}$ Há uma série de estudos acerca das primeiras experiências feitas pelos fazendeiros das áreas cafeeiras com imigrantes europeus. A título de exemplo, ver: STOLCKE, Verena e HALL, Michael M. A introdução do trabalho livre nas fazendas de café de São Paulo. Revista Brasileira de História, São Paulo, 3 (6): 80-120, set. 1983.

${ }^{180}$ SALLES, Vicente. O Negro no Pará - Sob o Regime da Escravidão. Rio de Janeiro: Fundação Getúlio Vargas, 1971. O autor critica uma tese corrente de que a escravidão negra teria desempenhado um papel menos importante na região do que a escravidão indígena.
} 
governo pela falta de apoio à região, por não retribuir com investimentos em infraestrutura os recursos que absorvia com o aumento das exportações.

Mas a explicação para o fracasso das tentativas colonizadoras não está numa suposta divisão da elite em setores progressistas - interessados no fomento à agricultura - e setores arcaicos - vinculados aos negócios da borracha. As posições, conforme assinalamos, oscilavam muito, dificultando o estabelecimento de clivagens regionais muito nítidas. A imagem associando o extrativismo ao retrocesso e a agricultura ao progresso foi produzida pelos grupos que acreditavam no desenvolvimento regional por meio desta última atividade.

A idealização do imigrante ou colono europeu como aquele que traria a salvação para a lavoura que, na visão dos administradores, parecia definhar, não resistiu ao duro golpe da realidade. Os estrangeiros que se instalaram em Benevides, ao invés de produzirem alimentos, levaram à Administração Provincial uma série de queixas e reivindicações, que parecem ter surpreendido a elite. A publicação das atas da Comissão de Colonização nos jornais revelou para a população local a dura realidade do processo de reorganização do mercado de trabalho: o imigrante, tão idealizado por presidentes de província e redatores, não era menos exigente nem mais trabalhador do que aqueles que aqui existiam. 


\section{Capítulo IV}

\section{Estranhos no Novo Mundo}

\subsection{A difícil convivência}

Em São Paulo, a chamada "imigração em massa", que teve início por volta de 1886, ocorreu após uma série de tentativas que fazendeiros, agências colonizadoras oficiais e particulares, Governo Provincial e Governo Imperial fizeram para atrair trabalhadores europeus. A primeira delas ocorreu na década de 1840, através do Senador Vergueiro. ${ }^{545} \mathrm{O}$ aparente sucesso de sua iniciativa fez com que outros fazendeiros se interessassem e passassem a negociar com ele a importação de imigrantes. Mas, de acordo com Warren Dean, houve apenas um entusiasmo inicial, pois chegaram menos imigrantes a Santos na década de 1860 do que na de $1850 .{ }^{546}$ As causas do fracasso foram questões trabalhistas, ${ }^{547}$ que resultaram na proibição, por parte de governos da Europa, da emigração de seus compatriotas para o Brasil. ${ }^{548}$

No início da década de 1870 , a convicção acerca da proximidade da abolição escravatura e o temor em relação a uma possível escassez de mão-de-obra fizeram com que a política de contratação de trabalhadores estrangeiros fosse retomada. Isto era possível, também, devido à existência de grandes contingentes de trabalhadores europeus dispostos a emigrar, o que estimulou alguns fazendeiros paulistas e seus

\footnotetext{
${ }^{545} \mathrm{O}$ governo apoiava a iniciativa de Vergueiro cuidando do envio dos imigrantes. A firma Vergueiro \& Cia. Tinha prazo de dois a quatro anos para pagar as despesas com as passagens, que depois eram cobradas dos colonos. Posteriormente, o Senador solicitou que o governo subvencionasse metade do valor das passagens para que os trabalhadores não chegassem tão endividados. BEIGUELMAN, Paula. A formação do Povo no Complexo Cafeeiro. Aspectos Politicos. $2^{\mathrm{a}}$ ed. São Paulo: Pioneira, 1977. p. 63.

${ }_{546}$ DEAN, Warren. Rio Claro. Um sistema brasileiro de grande lavoura. 1820-1920. Trad. Waldívia M. Portinho. Rio de Janeiro: Paz e Terra, 1977. p. 102.

${ }^{547}$ A visão dos trabalhadores sobre o conflito está narrada no clássico livro de Thomaz Davatz. Em seu não menos famoso "prefácio do tradutor", Sérgio Buarque de Holanda afirmou que o sistema Vergueiro chegou a ser adotado, em certo momento, por quase todos os principais fazendeiros de café em São Paulo. HOLANDA, Sérgio Buarque de. Prefácio do Tradutor. In: DAVATZ, Thomas. Memórias de um colono no Brasil (1850). Belo Horizonte: Itatiaia; São Paulo: Ed. da Universidade de São Paulo, 1980. p. 27.

${ }^{548}$ Segundo Warren Dean, a publicação do livro de Thomas Davatz e de um relatório do suiço J.C. Heusser, enviado pelo governo daquele país para analisar as reclamações dos colonos, fez com que a Prússia e a Suiça proibissem o recrutamento de imigrantes. Houve também protestos em Portugal e na Itália. DEAN, Warren. Op. cit. p. 107.
} 
aliados a atuar na busca de alternativas para a ampliação do mercado de trabalho na região.

Entretanto, conforme observaram Verena Stolcke e Michael M. Hall, a criação de uma força de trabalho não é uma questão meramente demográfica. ${ }^{549}$ Uma das dificuldades enfrentadas pelos fazendeiros, durante a segunda metade do século XIX, era a de manter o controle sobre o processo de reorganização do mercado de trabalho para garantir a eficiência da mão-de-obra livre. Para os autores, os fazendeiros apenas procuraram introduzir o trabalho livre em suas propriedades devido ao espectro da abolição da escravatura, e não em virtude de uma escassez de braços ou da convicção de que o trabalho livre era mais produtivo em relação ao trabalho escravo. Nesse sentido, experimentaram várias formas de trabalho - como a parceria, a locação de serviços e o colonato - até que conseguissem exercer algum controle mais efetivo sobre seus trabalhadores e, conseqüentemente, conseguissem garantir boas margens de lucros. Mas para que isto ocorresse teria sido fundamental a ação do governo, subvencionando a imigração em massa e criando mecanismos de controle dos trabalhos pelos seus empregadores através, por exemplo, da reforma da Lei de Locação de Serviços em 1879.

Muito se discutiu sobre as razões que levaram os cafeicultores paulistas a introduzir trabalhadores livres em suas propriedades. De um lado estão estão os autores que corroboraram o ponto de vista de Sérgio Buarque de Holanda, em Raízes do Brasil $^{550}$ de que os fazendeiros da região conhecida como Oeste Paulista administravam suas propriedades como empresários capitalistas, buscando racionalizar as formas de exploração para obter mais lucros. Como iniciaram suas plantações em meados do século XIX, quando ocorreu a proibição do tráfico negreiro, elevando o preço o escravo e colocando no horizonte a perspectiva da abolição final, estes fazendeiros teriam recorrido ao uso de trabalhadores livres e percebido que seu emprego era menos oneroso do que o investimento em escravos. De outro lado estão autores que, assim como Michael M. Hall e Verena Stolke, concluíram que o recurso à mão-de-obra livre, em particular do imigrante europeu, não decorreu de uma mentalidade empresarial ou capitalista, nem propriamente de uma escassez de trabalhadores, mas devido ao

\footnotetext{
${ }^{549}$ STOLCKE, Verena e HALL, Michael M. A introdução do trabalho livre nas fazendas de café de São Paulo. Revista Brasileira de História, São Paulo, 3 (6): 80-120, set. 1983.

${ }^{550}$ HOLANDA, Sérgio Buarque de. Raízes do Brasil. 17a . ed. Rio de Janeiro: José Olympio, 1984. p. 129.
} 
receio de que com, a abolição os escravos, abandonassem as plantações. Baseando-se em evidências empíricas, alguns destes autores assinalam a continuidade do emprego de mão-de-obra escrava mesmo naquela região e a obtenção de boas margens de lucro. Estes autores questionaram, sobretudo, a associação entre escravidão e irracionalidade econômica. $^{551}$

A experiência do Senador Vergueiro foi reeditada, com algumas modificações, a partir do início da década de 1870, quando o Senador Souza Queiroz, o comendador Souza Barros e o comendador Joaquim Bonifácio do Amaral, entre outros, contrataram trabalhadores europeus para suas fazendas. Este último o fez, dirigindo-se pessoalmente à Europa, após obter do Governo Imperial alguns "favores", que compensariam as despesas de transporte dos imigrantes. Sua chegada ao continente coincidiu com a Guerra Franco-Prussiana, o que impediu o recrutamento de trabalhadores naqueles países; o Barão seguiu, então, para o Tirol onde recrutou várias famílias. ${ }^{552}$ As principais mudanças foram no sistema de trabalho adotado, com o abandono da parceria, e a maior participação do governo no recrutamento dos imigrantes.

Em 1871, o Presidente da Província Antônio da Costa Pinto e Silva argumentou que, mesmo sem a ajuda do governo, os gastos com essas importações seriam mínimos e recompensados pelo aumento da oferta de braços, o desenvolvimento da agricultura e da produção, o que significaria um passo importante no sentido da "transição mais completa sem maior abalo para o proprietário e para o país em geral". 553 Poucos meses depois, no entanto, o Governo Imperial já estaria colaborando com os fazendeiros interessados em contratar imigrantes, por intermédio da Associação

\footnotetext{
${ }^{551}$ Entre os autores da primeira vertente, sempre com algumas variações, estão, além de Sérgio Buarque de Holanda, Florestan Fernandes, Emília Viotti da Costa, Octavio Ianni, Fernando Henrique Cardoso e Paula Beiguelman, entre outros. A segunda vertente, que também apresenta variações, é constituída por Peter Eisenberg, Robert Conrad, Robert Slenes, Jacob Gorender e Célia Maria Marinho de Azevedo, entre outros.

552 O Barão e, depois, Visconde de Indaiatuba era um dos remanescentes das primeiras tentativas de utilização da mão-de-obra européia na cafeicultura. Em 1852, iniciou a colonização da fazenda Sete Quedas, em Campinas, com trabalhadores alemães, mas teria tido problemas porque eles "pouco trabalharam e fizeram exigências repetidas e algumas delas inatendíveis". VISCONDE DE INDAIATUBA. Memorandum sobre o início de colonização da Fazenda "Sete Quedas", no município de Campinas, em 1852 pelo... In: Monografia Histórica do Município de Campinas. Rio de Janeiro, 1952 apud BEIGUELMAN, Paula. Loc. cit.

${ }^{553}$ Quanto às "colônias governamentais" existentes em São Paulo, Antônio da Costa Pinto e Silva mencionou a de Cananéia, classificando-a como "uma tentativa mal concebida e que nada prometia", do Avanhandava e Itapura. São Paulo. Relatorio apresentado á Assembléa Legislativa Provincial de S. Paulo pelo Presidente da Província o Exm. Sr. Dr. Antonio da Costa Pinto Silva no dia 5 de fevereiro de 1871. S. Paulo: Typ. Americana, 1871. p. 39-42.
} 
Auxiliadora da Colonização. ${ }^{554}$ Esta empresa atuava amparada por leis provinciais, promulgadas em 1871 e 1872 especialmente para promover a colonização. ${ }^{555}$ Todavia, nos anos que se seguiram, uma nova onda de conflitos trabalhistas agitou algumas colônias particulares, colocando mais uma vez em risco a imigração estrangeira.

Segundo Francisco Xavier Pinto Lima, ${ }^{556}$ em 1871, o comendador Joaquim Bonifacio do Amaral e o desembargador Bernardo Avelino Gavião Peixoto haviam assinado contratos com o Governo Imperial para introduzir, cada um, duzentos colonos em suas fazendas. Contudo, até o ano seguinte, o comendador teria importado apenas 118 colonos e o desembargador 81. Logo em seguida, porém, na colônia do desembargador, situada no município de Capivary, alguns imigrantes portugueses teriam se queixado do proprietário através de publicações em jornais locais.

Convidado pela Administração Provincial a visitar o local, o Vice-Cônsul de Portugal em São Paulo teria considerado as queixas "manifestamente infundadas", visto que o desembargador Gavião Peixoto fazia em favor dos seus colonos "mais do que aquilo a que para com eles se obrigara". Todavia, diante da insistência dos colonos, cujas queixas podiam "desconceituar" na Europa a colonização brasileira e "entorpecer a migração", o Presidente da Província determinou, em cumprimento de ordem superior, que o chefe de policia examinasse o local pessoalmente e colhesse todas as informações e esclarecimentos que fosse possível. A autoridade policial teria, então, colhido depoimentos de terceiros, interrogado colonos, examinado seus contratos e cadernetas, chegando à mesma conclusão do Vice-Cônsul de Portugal.

Na colônia São Lourenço, pertencente ao comendador Luiz Antonio de Souza Barros, os trabalhadores também estariam insatisfeitos. A pedido do fazendeiro, que desejava se justificar das queixas feitas pelos colonos e, dessa forma, "firmar o crédito do seu estabelecimento colonial", o Ministério da Agricultura, Comércio e Obras Públicas encarregara a Administração Provincial de nomear uma comissão para

\footnotetext{
${ }^{554}$ São Paulo. Relatorio com que o Exm. Sr. Conselheiro Francisco Xavier Pinto Lima passou a administração da Província ao Exm. Sr. Dr. João Theodoro Xavier, Presidente da mesma. S. Paulo: Typ. Americana, 1872. p.16-17.

${ }_{555}$ Ibidem. p.16-17.

${ }^{556}$ Ibidem. p.29-33.
} 
examinar a referida colônia, escrituração e proceder aos necessários inquéritos para verificar o que pudesse haver de exato nas queixas dos colonos. ${ }^{557}$

De acordo com Sérgio Buarque de Holanda, avaliando-se as causas do malogro de muitos dos diversos esforços de colonização agrária tentados em São Paulo no século XIX, nenhuma parecerá à primeira vista mais grave do que as condições de trabalho a que ficavam sujeitos os imigrantes. ${ }^{558}$ Mas os Presidentes da Província não pareciam dispostos a reconhecer o problema. Após os incidentes, a maioria deles pouco se referiu às colônias particulares, limitando-se, em geral, a mencionar o número de colonos importados ou que seus proprietários não os informavam sobre o que lá se passava.

Em 1875, por exemplo, João Theodoro Xavier mencionou a existência na Província de colônias nas propriedades de Antônio Moreira de Barros, em Taubaté; do comendador Joaquim Bonifácio Amaral, em Campinas; do comendador João Elisiário de Carvalho Montenegro, em Mogy-mirim; e colônias da fazenda Angélica, pertencente ao Banco Inglês, e colônia Morro Azul, de Silvério Rodrigues Jordão, ambas em Limeira. Entretanto, alegou que apenas o proprietário da Morro-Azul, Silvério Rodrigues Jordão, situada no município de Limeira, teria prestado informações, assegurando que os estrangeiros nela instalados estavam "satisfeitos pelos bons resultados que auferiam". ${ }^{559}$ Haveria naquele local 18 famílias, das quais 14 haviam se estabelecido em 21 de setembro de 1871, data da criação da colônia. O proprietário teria argumentado que o colono português era o que mais facilmente se habituava ao regime de serviço ali adotado, seguido do alemão, principalmente o do Norte.

Em 1876, porém, Sebastião José Pereira declarou que tinha conhecimento apenas das colônias do Barão de Souza Queiroz e dos comendadores Joaquim Bonifácio Amaral, Luiz Antônio de Souza Barros e João Elisiário de Carvalho. Segundo ele, caso tais fazendeiros tivessem imitadores não haveria receios quanto à transformação que ocorreria em breve, mas a maioria se satisfazia com o presente e se descuidava do futuro. Além disso, informou que dos 3.289 imigrantes introduzidos na Província no ano anterior, segundo dados oficiais, 43 se destinavam à colônia do comendador

\footnotetext{
${ }^{557}$ João Theodoro Xavier afirmou que até o momento da elaboração do relatório a comissão não havia apresentado suas conclusões, as quais não foram também comentadas nos relatórios dos seus sucessores.

${ }_{558}^{55}$ HOLANDA, Sérgio Buarque de. Prefácio do Tradutor. Op. cit. p. 21.

${ }^{559}$ São Paulo. Relatorio apresentado a Assembléa Legislativa Provincial de S. Paulo pelo Exm. Sr. Dr. João Theodoro Xavier Presidente da Província no dia 14 de fevereiro de 1875. S. Paulo: Typ. do Diario, 1875. p.87 a p.91.
} 
Montenegro, o que demonstrava que o número de contratados diretamente pelos fazendeiros era muito reduzido. ${ }^{560}$

Os fazendeiros paulistas não perderam o interesse pela contratação de trabalhadores europeus, apesar das greves de colonos e do pouco destaque dado pelos presidentes da Província às colônias particulares. Muitos deles participaram diretamente das iniciativas governamentais, assumindo funções sem remuneração no "serviço de imigração" da presidência da Província, constituindo comissões para assessorá-la e fundando associações, sem fins lucrativos, destinadas a contratar trabalhadores na Europa.

Antonio da Silva Prado e o Barão de Souza Queiroz, por exemplo, assumiram a direção do serviço de imigração na recepção, alojamento, alimentação e emprego dos colonos; ${ }^{561}$ Bento Francisco de Paula e Souza, Raphael Paes de Aguiar Barros e João Tebiriçá Piratininga fizeram parte de uma comissão encarregada pela Administração Provincial de analisar a criação de uma escola agrícola; Nicolau de Souza Queiroz, Raphael Paes de Barros e Martinho Prado Júnior estiveram à frente da Sociedade Promotora da Imigração. ${ }^{562}$ Isto sem falar da participação destes e de outros fazendeiros na Assembléia Legislativa Provincial e no Parlamento, apresentando e debatendo projetos de incentivo à imigração européia, bem em várias pastas ministeriais, principalmente no Ministério da Agricultura e no Ministério dos Estrangeiros, que tiveram à sua frente, em momentos distintos, os fazendeiros paulistas Antônio da Silva Prado e Rodrigo Silva.

O que mudou a partir de meados da década de 1870 em São Paulo, conforme observaram Verena Stolcke e Michael M. Hall, foi que o governo passou a subvencionar as passagens dos imigrantes, a importá-los em grande número e a criar mecanismo que permitiam as fazendeiros impor a disciplina de trabalho em suas propriedades. Assim, os cafeicultores puderam recrutá-los sem ter que se deslocar até à Europa, contratar agentes ou associações de imigração. Os conflitos trabalhistas também

\footnotetext{
${ }^{560}$ São Paulo.Relatorio apresentado a Assembléa Legislativa Provincial de S. Paulo pelo Presidente da Província Exm. Sr. Dr. Sebastião José Pereira em 27 de junho de 1876 por occasião da abertura de sua reunião extraordinaria. São Paulo: Typ. do Diario, 1876. p. 50.

${ }^{561}$ São Paulo. Relatorio apresentado a Assembléa Legislativa Provincial de S. Paulo pelo Presidente da Província Exm. Sr. Dr. Sebastião José Pereira em 27 de junho de 1876 por occasião da abertura de sua reunião extraordinaria. S. Paulo: Typ. do Diario, 1876. p.64-65.

${ }^{562}$ São Paulo. Relatorio apresentado á Assembléa Legislativa Provincial de S. Paulo pelo Presidente da Província Laurindo Abelardo de Brito no dia 13 de janeiro de 1881. Santos: Typ. do Diario de Santos, 1881. p.27.
} 
diminuiriam drasticamente, mas não só pelo fato de o trabalhador chegar às fazendas sem dívidas. Principalmente porque, devido às pressões dos que haviam chegado antes, da imprensa, agentes consulares e governos estrangeiro, os fazendeiros introduziram mudanças significativas no sistema de trabalho.

Isto não significa, contudo, que a imigração em massa ocorreu de forma natural, nem que outras formas de conduzir o processo de reorganização do mercado de trabalho fossem tentadas pelo governo. Cerca de quarenta anos decorreram entre as experiências do Senador Vergueiro e o estabelecimento de um fluxo contínuo e significativo de imigrantes em São Paulo. Neste período, fazendeiros, políticos, burocratas, redatores de jornais e outros setores da sociedade tiveram de ajustar expectativas, adequar imagens, fazer concessões, enfim, negociar sua identidade, para utilizar uma expressão de Jeffrey Lesser, a fim de que conseguissem resolver satisfatoriamente a questão da reorganização do mercado de trabalho na Província.

\subsection{A opção conservadora}

Além das colônias particulares, havia em São Paulo colônias mantidas pelo Governo Imperial, algumas de caráter militar e outras civis. Segundo Carlos H. Oberacker Junior a criação de colônias agro-militares no Brasil estava vinculada à preocupação dos governantes, desde o período colonial, de fortalecer a unidade estatal e o poder central, em face dos elementos centrífugos, representados pelos grandes proprietários rurais, bem como de proteger o território e estimular a policultura para abastecer cidades ou exércitos em campanha. ${ }^{563}$ Após o Fico e antes da Independência, D. Pedro de José Bonifácio, provavelmente incentivados por D. Leopoldina, considerando a iminência de uma guerra com Portugal, enviaram representantes à Europa para contratar soldados e colonos alemães. De acordo com o autor, José

\footnotetext{
${ }^{563} \mathrm{O}$ autor citou como exemplos desta política as iniciativas do Marquês de Pombal no Vale do Amazonas e nas províncias de São Pedro do Rio Grande do Sul e Santa Catarina, com a instalação de colonos açorianos. No Norte, além dos açorianos também teriam sido instalados desertores casados com portuguesas. Os resultados, contudo, não teriam sido satisfatórios, pois os colonos do Vale do Amazonas se dedicaram ao extrativismo e os do Sul ao pastoreio e à pesca. Mais tarde, houve, segundo o autor, tentativas no Espírito Santo, na desembocadura do Itajaí, na Bahia e na fronteira sulina, algumas com exsolados portugueses e outras com alemães e imigrantes de outras partes da Europa. OBERACKER JUNIOR, Carlos H. A colonização baseada no regime da pequena propriedade agrícola. In: HOLANDA, Sérgio Buarque de (dir.). História Geral da Civilização Brasileira. $2^{\mathrm{a}}$ ed. São Paulo: Difel, 1969. p. 220225.
} 
Bonifácio se inspirava nas colônias agro-militares dos cossacos, em certas regiões da Rússia, cujos habitantes, sob a chefia de um oficial, eram lavradores, mas em caso de emergência estavam sempre prontos para defender suas fronteiras. ${ }^{564}$

Embora as condições daquele momento exigissem de preferência soldados para defender a emancipação política do país, a intenção de José Bonifácio seria, também, convencer os contemporâneos de que a adoção de braços livres era mais vantajosa do que a de escravos. ${ }^{565}$ Vários núcleos coloniais foram então estabelecidos, principalmente no Sul do Império, com famílias procedentes de regiões da futura Alemanha. Mas a crise do Primeiro Reinado contribuiu para a disseminação de um sentimento nativista e xenófobo, que em 1830 levou à promulgação de uma lei proibindo o governo de fazer quaisquer despesas com a imigração e colonização estrangeira. ${ }^{566}$ Quatro anos mais tarde, o Ato Adicional atenuaria esta medida ao passar para as províncias a decisão de adotar qualquer medida em relação à introdução de estrangeiros. Todavia, como os recursos das mesmas era muito limitado, até o último quartel do século XIX, a maioria das colônias fundadas em São Paulo eram iniciativa de particulares. ${ }^{567}$

Quanto às militares, os presidentes de província geralmente se referiam a duas: Avanhandava e Itapura, ambas fundadas no final da década de 1850. A colônia Avanhandava seria muito menos importante do que a Itapura, segundo o Presidente que governava a Província em 1872, o conselheiro Francisco Xavier Pinto Lima. A principal utilidade dela seria auxiliar as "varações" das canoas que navegavam no rio Tieté, no

\footnotetext{
${ }^{564} \mathrm{Na}$ Áustria, colônias semelhantes foram mantidas ao longo das extensas fronteiras húngaras contra os turcos. Ibidem. p. 222-23.

565 Otávio Tarquínio de Sousa, A Vida de Pedro I, apud ibidem. p. 223.

${ }^{566}$ As críticas às concessões de terras e outros benefícios para os imigrantes por parte do Governo eram constantes, principalmente da parte dos grandes fazendeiros. Nessas ocasiões, eles reclamavam os mesmos privilégios para os nacionais, empréstimos aos proprietários de terras ou a imigração subvencionada como forma de ampliar a oferta de braços. HOLANDA, Sérgio Buarque de. As colônias de parceria. In: HOLANDA, Sérgio Buarque de (dir.). História Geral da Civilização Brasileira. Op. cit. p. 245-246.

${ }^{567}$ OBERACKER JUNIOR, Carlos H. Op. cit. p. 229. Segundo Sérgio Buarque de Holanda, existiram poucas colônias oficiais em São Paulo. O autor menciona uma colônia açoriana fundada em Casa Branca, no ano de 1815, e duas alemãs: Santo Amaro e Itapecerica, em 1827. Entretanto, como veremos adiante, os administradores provinciais mencionam a existência de várias delas, principalmente na década de 1880. HOLANDA, Sérgio Buarque de. As colônias de parceria. In: Idem (dir.). História Geral da Civilização Brasileira. Op. cit. p. 245.
} 
salto que lhe deu o nome. ${ }^{568}$ A Itapura, localizada no extremo Oeste da Província, quase na foz do rio Tietê com o rio Paraná, foi criada pelo decreto $\mathrm{n}^{\circ}$. 2.200, de 26 de Junho de $1858{ }^{569}$ De acordo com o PresidenteJosé Luiz de Almeida Couto, ela estava a 188 léguas da capital da Província, sendo a comunicação entre ambas feita apenas por via fluvial até Piracicaba, através das chamadas monções, de onde o oficial encarregado se deslocava até São Paulo, a fim de receber o suprimento das despesas. Estas viagens duravam cerca de 30 dias rio acima, e 20 dias rio abaixo, sendo extremamente perigosas devido às 52 corredeiras e três enormes saltos. Poucas monções não sofriam prejuízos.

Dado o isolamento destas colônias, seus diretores reivindicavam a abertura de uma estrada de rodagem ligando-as entre si e com a cidade de Botucatu. Houve algumas tentativas nesse sentido, sendo a última delas no início da década de 1880. Logo em seguida, porém, sofrendo com o abandono do governo, principalmente após o término da Guerra do Paraguai, e com os ataques de índios, os escassos moradores da Avanhandava abandonaram o local.

De acordo com o Presidente da Província, em 1885 o estado sanitário da colônia Itapura era bom. As febres intermitentes, endêmicas naquele local, estariam se escasseando devido às grandes derrubadas, inclusive nas margens do rio, além da observância de preceitos higiênicos. Residiam na colônia 273 pessoas, em 24 prédios do Estado e 65 de particulares. As escolas, inclusive uma de música, eram freqüentadas por 45 crianças. O Estado possuía 51 animais e os particulares 469. A indústria reduzia-se a uma pequena fazenda de açúcar e aguardente, enquanto o comércio, a duas casas de negócio, as quais, providas em Piracicaba, vendiam seus gêneros aos colonos e habitantes de Santa-Anna do Paranahyba, com quem trocavam produtos por mantimentos. A maior parte dos habitantes ocupava-se do plantio de roças e da criação de animais, de onde tirava o estritamente necessário. ${ }^{570}$

A partir de 1871 algumas das administrações provinciais procuraram dotar a Província de São Paulo de colônias oficiais civis. Naquele ano, por exemplo, Antônio

\footnotetext{
568 São Paulo. Relatorio com que o Exm. Sr. Conselheiro Francisco Xavier Pinto Lima passou a administração da Província ao Exm. Sr. Dr. João Theodoro Xavier, Presidente da mesma. S. Paulo: Typ. Americana, 1872. p. 33.

${ }^{569}$ São Paulo. Falla dirigida á Assembléa Legislativa Provincial de S. Paulo na abertura da $2^{a}$ Sessão da $26^{a}$ legislatura em 10 de janeiro de 1885 pelo Presidente Dr. José Luiz de Almeida Couto. S. Paulo: typ. da Gazeta Liberal, 1885. p.56-58.

${ }^{570}$ São Paulo. Falla dirigida á Assembléa Legislativa Provincial de S. Paulo na abertura da $2^{a}$ Sessão da $26^{a}$ legislatura em 10 de janeiro de 1885 pelo Presidente Dr. José Luiz de Almeida Couto. S. Paulo: typ. da Gazeta Liberal, 1885. p.56-58.
} 
da Costa Pinto e Silva ${ }^{571}$ criticou seus antecessores pela falta de iniciativa nesse sentido. De acordo com ele, algumas tentativas haviam sido feitas, mas fracassaram devido à intenção de povoar o sertão. As regiões distantes dos núcleos urbanos não ofereciam ao colono as condições indispensáveis para a prosperidade dos núcleos: estradas e grandes centros de consumidores para os gêneros produzidos. Quanto aos gastos que teriam de ser feitos para a instalação dos núcleos, os cofres públicos seriam compensados com o aumento na arrecadação de impostos.

Não há registro nos relatórios, nas falas ou na imprensa de que fossem instalados imigrantes nas colônias militares de São Paulo, situadas em áreas de difícil acesso e inóspitas. A recomendação de Antônio da Costa Pinto e Silva sobre a melhor localização para as colônias de imigrantes era praticamente consensual e denotava uma concepção acerca do trabalhador nacional e do trabalhador europeu, que associava a disposição e capacidade para o trabalho a um pretenso estágio de civilização. Assim, enquanto o primeiro, habitante de um país ainda pouco desenvolvido, seria mais afeito aos trabalhos que exigiam grande força física e capacidade de resistência frente a condições precárias, os ditos civilizados seriam mais adequados às tarefas que requeriam inteligência, conhecimentos e técnicas avançadas.

Além disso, a preocupação de Antônio da Costa Pinto e Silva com a criação de núcleos coloniais provavelmente estava relacionada com a decisão do Governo Imperial de promover a emancipação gradual da escravatura. Tanto assim que, ao mesmo tempo em que era debatido o projeto e promulgada a lei que libertou os filhos de mulher escrava, assinava-se contratos com as empresas, como a Mackay Filho \&C. e Guilherme Hadfiel, para a importação anual de até cinco mil imigrantes europeus, escolhidos entre “agricultores e trabalhadores rurais bem morigerados, em condições de perfeita saúde e nunca maiores de 45 anos". ${ }^{572}$ Como o contrato não estabelecia o destino dos imigrantes, o Presidente da Província de São Paulo afirmou que haveria de ser São Paulo, devido suas "reconhecidas vantagens" quanto ao "clima, a salubridade e a

\footnotetext{
${ }^{571}$ São Paulo. Relatorio apresentado á Assembléa Legislativa Provincial de S. Paulo pelo Presidente da Província o Exm. Sr. Dr. Antonio da Costa Pinto Silva no dia 5 de fevereiro de 1871. S. Paulo: Typ. Americana, 1871. p.37-42

${ }^{572}$ São Paulo. Relatorio apresentado á Assembléa Legislativa Provincial de S. Paulo pelo Presidente da Província o Exm. Sr. Dr. Antonio da Costa Pinto Silva no dia 5 de fevereiro de 1871. S. Paulo: Typ. Americana, 1871. p.39.
} 
inexaurível uberdade de suas terras”. Estes imigrantes seriam instalados em núcleos coloniais do governo, mas também poderiam ser contratados pelos fazendeiros.

Além desses contratos, o Governo Imperial firmara outro, em 1871, com a Associação Auxiliadora da Colonização e Imigração, estabelecida na capital da Província, que ficava incumbida de introduzir quinze mil colonos num prazo de três anos. ${ }^{573}$ De acordo com Francisco Xavier Pinto Lima, vinte famílias alemãs, totalizando 143 pessoas, já haviam chegado a São Paulo, sendo imediatamente contratadas por "fazendeiros empenhados em promover a completa substituição dos escravos por trabalhadores livres". A lei no. 42, de 30 de abril de 1871, que a Assembléia Legislativa Provincial havia promulgado, autorizava a presidência da Província a emitir apólices para auxiliar os "lavradores" interessados em importar colonos para os seus estabelecimentos agrícolas ou os próprios colonos, reduzindo despesas com passagens.

Entre as colônias mantidas pelo Governo Geral, a Cananéia não estaria apresentando resultados satisfatórios, devido à "esterilidade do terreno" em que estava situada, à falta de uma via regular de comunicação entre a colônia e as cidades próximas e à indolência dos colonos, que, avessos ao trabalho, não produziam seu próprio sustento. O Governo teria determinado a abertura de uma estrada para facilitar a comunicação da colônia, a qual, no entanto, fora interrompida porque seu encarregado havia sido incumbido de outra comissão na Província do Paraná. Em 1877, porém, o Presidente Sebastião José Pereira afirmou que esta colônia, antes prestes a se extinguir, estava sendo recuperada por um novo diretor, tendo no ano anterior já apresentado alguma plantação importante, embora sua população fosse muito limitada. ${ }^{574}$

O problema de estradas era comum a todas as províncias do Império e não afetavam apenas as colônias. Entretanto, no caso delas se tornava mais premente devido à necessidade de oferecer atrativos para os estrangeiros. Nesse sentido, Sebastião José Pereira afirmou ter solicitado do Ministro da Agricultura a fundação de núcleos coloniais nas proximidades da capital e de outras localidades, para as quais eram mais

\footnotetext{
573 São Paulo. Relatorio com que o Exm. Sr. Conselheiro Francisco Xavier Pinto Lima passou a administração da Província ao Exm. Sr. Dr. João Theodoro Xavier, Presidente da mesma. S. Paulo: Typ. Americana, 1872. p.31.

${ }^{574}$ São Paulo. Relatorio apresentado á Assembléa Legislativa Provincial de S. Paulo pelo Presidente da Província o Exm. Sr. Dr. Sebastião José Pereira em 6 de fevereiro de 1877. S. Paulo: Typ. do Diario, 1877. p.88-89.
} 
fáceis os meios de comunicação. Em resposta, o Ministro enviara uma comissão para medir terrenos devolutos existentes no município de Sorocaba, próximos à fabrica Ypanema, e autorizou a compra de duas fazendas pertencentes ao Mosteiro de São Bento. Essas fazendas, assim como os "terrenos nacionais" da Glória e Sant'Anna, seriam divididos em lotes destinados aos imigrantes. ${ }^{575}$

Os núcleos Sant'Anna, Glória, São Caetano e S. Bernardo foram, então, criados pelo Governo Imperial nas proximidades da capital paulista. Em 1880, Laurindo Abelardo de Brito ${ }^{576}$ afirmou que o Sant'Anna estava localizado a apenas $6 \mathrm{~km}$. da capital, com a qual se comunicava por boa estrada, ocupando uma área de 86 hectares, dividida em 155 lotes urbanos, com 26 casas provisórias. Na casa principal havia sido instalada uma hospedaria de imigrantes, que estava a cargo do agente oficial de colonização. As plantações consistiam em milho, feijão, batatas, cevada, hortaliças e outros gêneros de "pequena cultura". O núcleo havia sido emancipado em 30 de novembro de 1878 , tendo sido fundado por colonos de uma irmandade religiosa.

Quanto ao núcleo Glória, inaugurado a 26 de agosto de 1877 e distante apenas $3 \mathrm{~km}$ da capital, com ela se comunicava por duas boas estradas. Sua área, que era de $8.256 .808 \mathrm{~m}^{2}$, estava dividida em lotes rurais e urbanos. Alguns colonos estavam de posse de seus títulos provisórios e outros de títulos definitivos, por terem saldado sua dívida junto à Fazenda Nacional. O cultivo de cereais, no entanto, seria insignificante, pois os colonos preferiam se empregar como assalariados na capital ou se dedicar à produção de "cadeiras de capim" e venda de lenha em carroças. O núcleo já havia sido emancipado e, segundo o Administrador provincial, parte da fazenda Glória estava ocupada por "intrusos".

Já o núcleo São Caetano, inaugurado em 28 de julho de 1877, situava-se em uma fazenda que distava $10 \mathrm{~km}$ da capital e também com ela se comunicava através de uma boa estrada. Havia 54 lotes rurais e 26 urbanos, sendo que todos os chefes de família possuíam títulos provisórios. Alguns imigrantes, atraídos por parentes e amigos

\footnotetext{
${ }^{575}$ São Paulo. Relatorio apresentado á Assembléa Legislativa Provincial de S. Paulo pelo Presidente da Província o Exm. Sr. Dr. Sebastião José Pereira em 6 fevereiro de 1877. S. Paulo: Typ. do Diário, 1877. p.87.

576 Relatorio apresentado a Assembléa Legislativa Provincial de S. Paulo pelo Presidente da Província Laurindo Abelardo de Brito no dia 5 de fevereiro de 1880. Santos: Typ.do Diario de Santos, 1880. p.166172.
} 
ali estabelecidos, haviam se fixado no local posteriormente. Em razão disso, não havia mais lotes disponíveis. A principal atividade desenvolvida era o cultivo de cereais.

Por fim, o núcleo São Bernardo compreendia as fazendas São Bernardo Velho, Jurubatuba e São Bernardo Novo. As duas primeiras pertenciam a frades da ordem beneditina e a terceira aos herdeiros de um tenente. Estava situado a 23 quilômetros da capital e se comunicava tanto por estrada de rodagem quanto pela ferrovia da Companhia Inglesa. Haviam sido medidos e demarcados 166 lotes rurais e 49 urbanos. As plantações consistiam em cereais e começava a ensaiar-se a cultura de forragens. Os colonos já estavam de posse de seus títulos provisórios. De acordo com o Presidente da Província, depois de haverem recebido todos os favores que o governo lhes podia fazer, exigiram mais, e com a recusa mostravam-se dispostos a desordens. Algumas providências haviam sido tomadas, como a expulsão dos "chefes da perturbação", o que teria feito com que os colonos voltassem aos seus trabalhos. 577

De 1879 a 1885, coincidindo com o período em que o Partido Liberal organizou os ministérios, os presidentes de província pouco se referiam aos núcleos coloniais que o Governo Imperial havia fundado em São Paulo. Em 1887, já no período de domínio dos conservadores, o Barão do Parnahyba lamentou a emancipação, segundo ele prematura, dos núcleos Sant'Anna, Glória, São Caetano e S. Bernardo. ${ }^{578}$ Em seguida, afirmou que o então Ministro da Agricultura, Antônio da Silva Prado, "compenetrado das grandes vantagens que tinha a Província de auferir com o desenvolvimento dos núcleos coloniais", nomeara uma comissão de engenheiros para medir e demarcar novos lotes.

A fim de colaborar com a iniciativa, o Presidente teria feito uma viagem às cabeceiras do rio Juquiá, onde haveria grande quantidade de terras devolutas, para se certificar "de visu" da qualidade e valor dos terrenos e das vantagens de sua medição e divisão em lotes. Entretanto, segundo o Presidente, a distância do mercado, o isolamento, a proximidade do sertão e, mais do que tudo, a falta de aptidão do europeu recém-chegado para trabalhar nas matas virgens, eram obstáculos insuperáveis. Ele

\footnotetext{
577 São Paulo. Relatorio apresentado a Assembléa Legislativa Provincial de S. Paulo pelo Presidente da Província Laurindo Abelardo de Brito no dia 5 de fevereiro de 1880. Santos: Typ.do Diário de Santos, 1880. p.167-172.

${ }^{578}$ São Paulo. Relatorio apresentado a Assembléa Legislativa Provincial de São Paulo pelo Presidente da Província Barão do Parnahyba no dia 17 de janeiro de 1887. São Paulo: Typ. de Jorge Seckler \& Comp., 1887. p. 125.
} 
recomendou aos deputados provinciais a venda dos lotes ali demarcados a brasileiros que, internando-se pelo sertão, desbravariam a terra para que, posteriormente, fossem estabelecidos colonos europeus.

Peter Eisenberg se referiu ao trabalhador livre brasileiro como "homem esquecido", uma vez que para boa parte da historiografia o trabalho livre só se tornou importante na década de 1880, devido à abolição da escravatura e à imigração européia. $\mathrm{O}$ autor criticou especificamente a idéia, subjacente a esta interpretação, de incompatibilidade entre trabalho livre e trabalho escravo, argumentando que isso seria impossível em São Paulo, pois a porcentagem de escravos em relação ao restante da população reduziu drasticamente, passando de 28,5\%, em 1854, para 18,7\%, em 1872, e 8,8\%, em 1886. Em razão disso, o "elemento livre nacional" estaria presente em todas as atividades, inclusive naquelas relacionadas com a agricultura de exportação.

Mas como explicar, então, que as elites locais estivessem tão interessadas em buscar fontes externas de suprimento de mão-de-obra? O autor apontou algumas hipóteses da historiografia, mas descartou-as por considerá-las preconceituosas ou insuficientes. ${ }^{579}$ Em seguida, limitou-se a sugerir a realização de pesquisas que nos ajudariam a encontrar respostas mais convincentes, tais como averiguar quais eram os tipos múltiplos de trabalhadores nacionais; quais os custos para o fazendeiro que empregava esses grupos e quais as recompensas que os trabalhadores recebiam; quais forças eram capazes de deslocar esses trabalhadores para outras áreas ou outros serviços e qual sua capacidade real de trabalho.

Finalizando suas reflexões, Peter Eisenberg afirmou que mesmo quando o elemento estrangeiro veio a predominar no Oeste Paulista, o elemento nacional continuava a ser quase o único fornecedor de braços para a lavoura e muitas outras atividades no Norte, no Nordeste e no Oeste do país. Diante disso, colocou-nos mais uma questão: explicar a especificidade de São Paulo.

De fato, a análise de jornais, relatórios e falas dos presidentes de província demonstra que apenas vozes isoladas defendiam o emprego do trabalhador livre nacional. Na maioria das vezes elas partiam dos críticos da imigração, que

\footnotetext{
579 Existiriam duas hipóteses para explicar este aparente paradoxo: a que atribui ao elemento nacional uma incapacidade ou falta de vontade de participar no setor de exportação; e a que considera circunstâncias fora do controle do próprio trabalhador nacional, mais especificamente o preconceito dos empregadores, os custos financeiros e políticos da mobilização dessa mão-de-obra etc.
} 
reivindicavam para os nacionais o mesmo apoio dado aos estrangeiros. Não obstante, era muito difundida a idéia de que o imigrante europeu, ao contrário do escravo e do trabalhador livre nacional, não se sujeitaria aos trabalhos mais árduos. Daí porque o Barão de Parnahyba, ao elogiar a criação de colônias nacionais em São Paulo, propôs que elas fossem estabelecidas na proximidade das cidades e em áreas já preparadas para o plantio.

Entretanto, no mesmo relatório desse Presidente da Província, o Inspetor Geral de Imigração, Frederico José Cardozo de Araújo Abranches, sugeriu que o governo criasse colônias, mas para abrigar trabalhadores nacionais, e não estrangeiros. Seu argumento era que a população do país vivia em condições quase nômades e razões de ordem moral, social, econômica e política exigiam a atenção do governo para o problema. Milhares de pessoas moravam em terras que não eram suas, sujeitas ao arbítrio e caprichos dos proprietários, habitando míseras choupanas, ligeiramente edificadas, pois não conheciam os prazeres da "civilização". Mas esse "elemento semibárbaro" reclamava ser civilizado pelo trabalho, encaminhado para novos hábitos e costumes a fim de constituir forças ativas e criadoras, em vez de ser uma inutilidade ou um entrave ao progresso econômico do país.

Assim, perguntava o Inspetor, se ao imigrante estrangeiro eram concedidas tantas vantagens, com o objetivo de estabelecê-los na lavoura, porque não se fazia o mesmo com os nacionais "moralizados e trabalhadores", que ambicionassem trocar a sua condição de "agregados” pela de pequenos proprietários? Em seguida, contrariando o Barão de Parnahyba, que defendeu incentivos à grande propriedade, o inspetor ressaltou que a adoção pelo país do modelo de pequena propriedade criaria uma "raça vigorosa de paisanos altivos e livres", como os de Roma, nos primeiros tempos da República, e, na era moderna, os da Suíça, França e Noruega. A pequena cultura unida à pequena propriedade, com exceção da Inglaterra, seria responsável pela maior parte da produção agrícola da Europa. ${ }^{580}$

Dos presidentes que ocuparam a presidência da Província de São Paulo entre 1868 e 1889, o Barão de Parnahyba talvez tenha sido aquele que mais defendeu a grande propriedade. Curiosamente, seu relatório trouxe também a visão de um de seus

\footnotetext{
${ }^{580}$ ABRANCHES, Frederico José Cardozo de Araújo. "Imigração". In: São Paulo. Relatorio apresentado a Assembléa Legislativa Provincial de São Paulo pelo Presidente da Província Barão do Parnahyba no dia 17 de janeiro de 1887. São Paulo: typ. de Jorge Seckler \& Comp., 1887. Anexo 10.
} 
críticos, cujos argumentos pareciam mais fortes, pois propunham a utilização de recursos públicos em prol da melhoria das condições de vida de um contingente significativo de trabalhadores brasileiros. $\mathrm{O}$ momento em que escreviam era dramático para os grandes proprietários, uma vez que grandes levas de escravos abandonavam as fazendas no interior paulista e as perspectivas de contratar imigrantes europeus para substituí-los pareciam remotas. Entretanto, mais dramáticas ainda eram as condições do trabalhador livre nacional, como descreveu o inspetor de colonização, e principalmente dos escravos e ex-escravos.

Entretanto, o trabalhador livre nacional, o imigrante e o escravo só aparecem nas fontes que pesquisamos indiretamente, o que nos impede de responder com alguma objetividade as questões pertinentes colocadas por Peter Eisenberg. Podemos dizer, contudo, que embora ele tenha acertado ao dizer que enquanto São Paulo recebia um fluxo considerável de imigrantes a mão-de-obra utilizada no Norte era a nacional, isto não significa que no Pará, pelo menos, tal situação refletisse a vontade de uma parte expressiva dos grupos dominantes. Podemos ir adiante e questionar a clivagem estabelecida entre nacionais e estrangeiros, considerando que a utilização da mão-deobra do migrante cearense teve efeito análogo ao do emprego de imigrantes europeus, ou seja, significou também a exclusão do mercado de trabalho da população nativa do Vale Amazônico.

$\mathrm{Na}$ realidade, lidamos com representações produzidas por determinados grupos em relação a outros. Expressões como "elemento nacional”, "imigrante”, "índio" e "escravo", da mesma forma que "fazendeiro", "comerciante", "missionário", "político", "burocrata" etc. são generalizações grosseiras, que quase nunca correspondem a tipos humanos concretos. Mas esta é outra questão. O que queremos assinalar é que nos jornais, relatórios e falas dos presidentes nos deparamos com imagens que alguns agentes elaboravam sobre outros. Estas imagens, contudo, nem sempre guardavam relação com o representado, mas muitas vezes como aquele que se imaginava ser o seu oposto. Assim, as imagens do imigrante e do trabalhador livre nacional foram construídas num jogo de oposições, em que a imagem de um seria o contrário da imagem do outro. Disso resulta que o trabalhador livre nacional não estava propriamente esquecido, mas representado, ainda que de forma invertida, na imagem produzida sobre o imigrante. 
O revezamento de Antônio da Silva Prado e Rodrigo Silva no Ministério da Agricultura e no Ministério dos Estrangeiros, entre 1885 e 1888, contribuiu não só para a criação de novos núcleos coloniais pelo Governo Imperial como também para as tentativas de revitalização dos núcleos antigos. ${ }^{581}$ Os efeitos dessa política foram relatados pelo Barão de Parnahyba no ano seguinte, ${ }^{582}$ ao mencionar a criação dos núcleos Senador Prado, em Ribeirão Preto; Conselheiro Rodrigo Silva, em Porto Feliz; Barão de Jundiahy, em Jundiaí. O Governo estaria revitalizando núcleos antigos em Iguape - núcleo Pariquéra-Assú - e na capital - São Bernardo, São Caetano e Sant'Anna. Entusiasmado com essas iniciativas, o Presidente da Província afirmou, então, que o Governo Geral devia se encarregar de estabelecer e manter todos os núcleos coloniais de São Paulo.

Quando aos núcleos da capital, 348 lotes já teriam sido medidos e demarcados definitivamente, de acordo com o plano de sua ocupação, bem como organizados os respectivos memoriais descritivos: em S. Bernardo 205; em S. Caetano 74; em Santa Anna 69. O Presidente da Província se mostrou satisfeito pelo fato de a delimitação dos lotes não ter levantado dúvidas, o que ele atribuiu ao fato de o governo haver adotado meios conciliatórios com os interesses e direitos adquiridos pelos antigos colonos. Além disso, recomendou a distribuição dos lotes vagos e abandonados a novos imigrantes e agricultores nacionais.

\footnotetext{
${ }^{581}$ Antônio da Silva Prado era o principal líder do Partido Conservador em São Paulo, tendo assumido a pasta da Agricultura no Gabinete Ministerial presidido pelo Barão de Cotegipe, em 20 de agosto de 1885. Era o primeiro gabinete formado pelos conservadores desde a "inversão partidária" de 1878, que levara os liberais ao comando do Governo. Em agosto de 1885, uma grave crise política, motivada pelo debate do projeto que resultaria na chamada Lei dos Sexagenários, ou Lei Saraiva-Cotegipe, fez com que D. Pedro II, fazendo uso das prerrogativas do Poder Moderador, convidasse os conservadores para reassumirem a Presidência do Conselho de Ministros. Antônio Prado permaneceu na pasta até 10 de outubro de 1887, sendo substituído por Rodrigo Augusto da Silva. Quando o Gabinete do Barão de Cotegipe deu lugar ao de João Alfredo Correia de Oliveira, em 10 de março de 1888, Antônio da Silva Prado foi nomeado para o Ministério dos Estrangeiros e Rodrigo Silva continuou no Ministério da Agricultura. Em 27 de junho de 1888 houve uma inversão: Antônio da Silva Prado foi para o Ministério da Agricultura e Rodrigo Silva para o dos Estrangeiros. Em 1889, descontente com a política do Gabinete João Alfredo, Antônio Prado se retirou do Ministério da Agricultura, sendo novamente substituído por Rodrigo Silva, que permaneceu à frente da pasta até a "inversão partidária" de 7 de junho de 1889, a última da monarquia. Ver. BARÃO DE JAVARI (org.). Organizações e Programas Ministeriais. Regime parlamentar do Império. 3. ed. Brasília: Ministério da Cultura/Departamento de Documentação e Divulgação, 1979. p. $219-249$.

${ }^{582}$ São Paulo. Exposição com que o Exm. Snr. Visconde do Parnahyba passou a administração da província de São Paulo ao Exm. Snr. Dr. Francisco de Paula Rodrigues Alves Presidente desta Província no dia19 de novembro de 1887. São Paulo: typ. de Jorge Seckler \& Comp., 1888. p. 119-120.
} 
Um recenseamento feito nos núcleos antigos indicara a existência de 207 lotes desocupados, sendo $47 \mathrm{em} \mathrm{S.} \mathrm{Bernardo,}{ }^{583} 28 \mathrm{em} \mathrm{S}$. Caetano, ${ }^{584} \mathrm{em} 132 \mathrm{em}$ Sant'Anna. ${ }^{585}$ Alguns deles já teriam sido ocupados pelos próprios designados e os demais distribuídos a colonos recém-chegados. Os que restavam tinha sido rejeitados em razão da má qualidade das terras, da sua localização ou pelo fato de o terreno ser acidentado. O Presidente afirmou, ainda, que autorizara os melhoramentos da estrada de rodagem que ligava a sede do núcleo São Bernardo à Estação do mesmo nome e que outras estradas e caminhos haviam sido projetados e orçados, estando alguns em construção.

Sobre o núcleo Pariquéra-Assú, situado em Iguape, o Presidente não informou a data de sua fundação. O Relatório da Comissão das Terras Públicas, de 1872, mencionara sua divisão em 144 seções, das quais, porém, restariam mais vestígios. Os dados colhidos pela administração indicavam a existência, naquele local, de 188 homens e 153 mulheres. Havia 7 lotes distribuídos e 20 disponíveis. A Comissão de Colonização e Imigração havia iniciado trabalho no local, medindo 27 lotes, mas seu Presidente suspendeu os trabalhos à espera de indicações do Presidente da Província.

O Presidente transmitiu, também, as informações prestadas pela Comissão sobre o núcleo Senador Antonio Prado, situado em Ribeirão Preto. O núcleo seria instalado em uma área pertencente ao Ministério da Fazenda, que a havia cedido ao da Agricultura para a instalação de colonos. Inicialmente, foram instalados 9 colonos alemães; quando da elaboração do relatório, este número se elevara para 65 homens e 46 mulheres. O total de lotes era de 161, dos quais 78 estavam medidos. Destes, 23 estavam distribuídos, havendo 55 disponíveis. Quando ao núcleo Barão de Jundiahy, situado a três quilômetros de Jundiaí, haviam sido inicialmente instalados 22 colonos

\footnotetext{
${ }^{583}$ O núcleo São Bernardo havia sido fundado em 2 de julho de 1886 e inaugurado em 3 de setembro do ano seguinte, quando teriam sido instalados 51 colonos. A área fora comprada pelo Estado junto à ordem beneditina e abrangia a superfície aproximada de 1.959,37 hectares. Havia no núcleo 507 homens e 378 mulheres; 192 lotes demarcados e 109 distribuídos. Próximas à sede do núcleo funcionavam duas escolas, mantidas pela Administração Provincial, as quais eram freqüentadas por 52 alunos, sendo a metade de cada sexo.

584 O núcleo São Caetano, fundado em 28 de Janeiro de 1877, numa fazenda que também pertencera à Ordem Beneditina, tinha uma área de 1.089,099 hectares. O número total de habitantes era de 134 homens e 117 mulheres. Havia 85 lotes demarcados e 15 distribuídos. A exemplo do núcleo São Bernardo, funcionavam ali dois estabelecimentos escolares, mantidos pelo Governo Provincial, com 25 alunos do sexo masculino e 28 do sexo feminino.

${ }^{585}$ Este núcleo fora inagurado em 1 de julho de 1877, distante 6 quilômetros da Capital, e já estava emancipado. Sua área era de 84,64 hectares e os habitantes divididos em 70 homens e 66 mulheres, sendo 69 o número de lotes demarcados e 20 o de lotes distribuídos.
} 
italianos, mas a inauguração oficial ainda não ocorrera pois o barracão para alojamento dos imigrantes ainda não estava concluído. Naquele momento, já havia no local 55 homens e 44 mulheres, todos italianos, com exceção apenas de um francês. ${ }^{586}$

Sobre o núcleo Conselheiro Rodrigo Silva, localizado em Porto Feliz, informou que sua inauguração dependia da chegada do Padre Jean Baptiste Vanesse, que assinara um contrato com o Governo Imperial para instalação de famílias belgas. Por este contrato, o Governo deveria demarcar os lotes fazer melhoramentos para promover o desenvolvimento do núcleo, tais como a construção de estradas e caminhos vicinais, barracão para alojamento provisório dos imigrantes, igreja para culto e edifício onde funcionaria uma escola. Além disso, deveria reformar uma casa existente no local, que seria utilizada para a diretoria do núcleo e residência do Padre Vanesse.

O Presidente da Comissão de Colonização informou, ainda, que autorizara o inspetor especial de terras e colonização a providenciar obras de concertos urgentes nas estradas e caminhos dos núcleos coloniais existentes na Província, especialmente para o de S. Bernardo. Estas estradas seriam pagas pelo respectivo Ministério. O Presidente informou, ainda, que recebera do tenente-coronel Emygdio José da Piedade uma área no Ribeirão da Prata, em Campos Novos de Paranapanema, termo de Santa Cruz do Rio Pardo, para estabelecimento de uma colônia agrícola ou outra qualquer que fosse julgada mais conveniente. ${ }^{587}$

De acordo com o Presidente da Comissão de Colonização, o Ministério da Agricultura havia concedido um crédito de 11:000\$000 para a construção de um alojamento dos imigrantes em Ribeirão Preto. Além disso, o Presidente informou que tomara procedimentos para a compra de diversas áreas na Província a fim de serem destinadas à colonização, ordenara a construção de uma estrada ligando a sede do Núcleo Colonial de S. Bernardo à estação do mesmo nome, a continuação das às obras da colônia do Pariquera-assú, em Iguape, a construção de um alojamento provisório no núcleo colonial do Ribeirão Preto e de um barracão no núcleo Barão de Jundiahy, e a contratação do médico Aristides Franco Meirelles, para cuidar dos imigrantes estabelecidos nas colônias de S. Bernardo e S. Caetano, acometidas por uma epidemia da varíola.

\footnotetext{
${ }^{586}$ Ibidem. p. 123.

${ }^{587}$ Ibidem. p. 124.
} 
Todas estas providências, realizadas no período em que Antônio Prado e Rodrigo Silva ocuparam as pastas do Ministério da Agricultura e, apenas o último, o Ministério dos Estrangeiros revelam uma ação coordenada dos políticos conservadores para levar adiante uma determinada política de mão-de-obra em São Paulo. Se no período de domínio dos liberais, entre 1878 e 1885, a imigração asiática tornou-se a principal alternativa para o fornecimento de braços para as lavouras, a instalação de núcleos coloniais, conjugada à imigração subvencionada, foi a proposta dos conservadores. Esta política ficou evidente não apenas na prática de atribuir a alguns núcleos os nomes de lideranças políticas locais, como os de Antônio Prado (Ribeirão Preto), Barão de Jundiahy (Jundiaí) e Rodrigo Silva (Porto Feliz), mas também pelo fato de outras lideranças conhecidas do Partido Conservador em São Paulo, como Emygdio José da Piedade, José Luiz de Almeida Couto e Domingos José Nogueira Jaguaribe Filho doarem ou venderem propriedades para o governo a fim de serem criados núcleos coloniais.

\subsection{A outra face da moeda}

As colônias provinciais, segundo o Presidente João Theodoro Xavier, foram reguladas pelo Decreto no. 3.784, de 19 de Janeiro de 1867, que estabeleceu como seria feita a distribuição de terras e as condições de propriedade. Baseada nessa lei, a Administração Provincial teria firmado, em novembro de 1871, um contrato com a Associação de Colonização e Imigração para a instalação e manutenção de colônias nas proximidades das estradas de ferro, ou seja, onde "o interesse da produção", a "facilidade do consumo" ofereciam garantias de "permanência e estabilidade".

Esta associação teria introduzido na Província de São Paulo, em janeiro de 1874, 131 colonos alemães e, em julho, 68 portugueses, assinando, em seguida, uma prorrogação do prazo que tinha para fundar as colônias, de 3 para 5 anos. ${ }^{588}$ Como os presidentes não voltaram a tocar no assunto, é provável que ela não tenha conseguido

\footnotetext{
${ }^{588}$ São Paulo. Relatorio apresentado a Assembléa Legislativa Provincial de S. Paulo pelo Presidente da Província o Exm. Sr. Dr. João Theodoro Xavier em 5 de fevereiro de 1874. S. Paulo: Typ. Americana, 1874. p.15. Em 1875, João Theodoro Xavier afirmou que celebrara com o Presidente da Associação Auxiliadora da Colonização e Imigração da Província, amparado pela Lei n. 44 de 17 de abril daquele ano, para a introdução de imigrantes na províncial. São Paulo. Relatorio apresentado a Assembléa Legislativa Provincial de S. Paulo pelo Exm. Sr. Dr. João Theodoro Xavier Presidente da Província no dia 14 de fevereiro de 1875. S. Paulo: Typ. do Diario, 1875. p.117.
} 
cumprir o estabelecido. Passado o momento mais crítico da década de 1870, que foi aquele imediatamente posterior à promulgação da Lei do Ventre Livre, quando o Governo recebeu várias críticas dos fazendeiros e dos representantes destes, por haver interferido nas relações entre senhor e escravo sem cuidar para que uma fonte alternativa de braços fosse encontrada, os relatórios e falas dos presidentes de província deixaram de relatar a criação de núcleos coloniais oficiais em São Paulo.

Em 1881, Laurindo Abelardo de Brito ${ }^{589}$ afirmou que o Ministro do Império, com o apoio do Ministro da Agricultura, resolvera "internar" em São Paulo os imigrantes e colonos que chegassem ao porto do Rio de Janeiro, tendo como destino o Brasil. Em razão disso, decidira nomear um deputado da Assembléia Provincial, Nicolau de Souza Queiroz, para o cargo de Agente da Inspetoria Geral das Terras Públicas e Colonização, com a finalidade de "agasalhar" os imigrantes que chegassem. O Governo Provincial providenciaria, portanto, a hospedagem dos trabalhadores até que eles fossem contratados por fazendeiros. Outra opção seria instalá-los em colônias provinciais ou gerais.

Dois anos mais tarde, tendo a Administração Provincial recebido de João Álvares de Siqueira Bueno a doação de uma área que lhe pertencia, ${ }^{590}$ localizada na freguesia de N. S. da Conceição dos Guarulhos, para a criação de um núcleo colonial, providenciou a demarcação e divisão dos lotes, que perfizeram o total de dez. Em três deles, segundo o Presidente da Província, foram estabelecidas de imediato famílias de imigrantes alemães, às quais o Governo Provincial forneceu também ferramentas, sementes e auxilio pecuniário para a construção de habitações provisórias. Tudo isso deveria ser pago pelos colonos quando começassem a produzir.

Outra providência da Administração Provincial foi a constituição de uma comissão, composta do Delegado de Imigração, do Procurador Fiscal e do Diretor Geral de Obras Públicas, com a finalidade de elaborar um regulamento para servir de base à criação de núcleos coloniais provinciais. Quanto aos recursos, Francisco Soares de Carvalho solicitou que os deputados provinciais aprovassem a destinação de uma verba

\footnotetext{
${ }^{589}$ São Paulo. Relatorio apresentado á Assembléa Legislativa Provincial de S. Paulo pelo Presidente da Província Laurindo Abelardo de Brito no dia 13 de janeiro de 1881. Santos: Typ. do "Diário de Santos", 1881. p.27.

${ }^{590}$ São Paulo. Falla dirigida a Assembléa Legislativa Provincial de S. Paulo na abertura da $2^{a}$ sessão da $24^{a}$ Legislatura em 10 de janeiro de 1883 pelo Presidente Conselheiro Francisco de Carvalho Soares Brandão. S. Paulo: Typ. do Ypiranga, 1883. p.27-28.
} 
para aquisição de terras apropriadas, pois, sendo a concessão de lotes aos imigrantes uma das finalidades das leis provinciais, e uma promessa do governo brasileiro aos países europeus, era preciso providenciar o assunto para que o desenvolvimento da imigração não ficasse comprometido.

Os relatórios e falas dos presidentes de província registraram um aumento crescente no número de imigrantes que entravam na Província, os quais se dirigiam, em sua maioria, para os estabelecimentos agrícolas do interior. Em 1883, o Visconde de Itu afirmou que, diante dos dados que dispunha, acreditava que a produção não sofreria um abalo tão forte como se espera quando ocorresse a abolição da escravatura. ${ }^{591}$ Ainda se referindo aos dados daquele ano, o sucessor do Visconde na Administração Provincial, Barão de Guajará, corroborou suas conclusões, afirmando que a "corrente da imigração" aumentava progressivamente, a ponto de atingir quase o dobro das entradas de $1882 .{ }^{592}$ Os imigrantes eram, em geral, homens solteiros, habituados ao trabalho agrícola e proveniente da região Norte da Itália. De acordo com o Presidente, os daquela região correspondiam melhor às exigências dos agricultores, que os procuravam para firmar contratos de trabalho em detrimento dos de outra nacionalidade.

Os administradores não pareciam se preocupar com o fato de a maioria dos imigrantes europeus serem do sexo masculino. Os críticos da importação de coolies, ao contrário, apontavam isto como um dos maiores empecilhos à sua contratação. A explicação mais provável é de que não havendo preconceito étnico contra os europeus, admitia-se com mais naturalidade um desequilíbrio entre os sexos. Mesmo porque o principal interesse em introduzir trabalhadores estrangeiros no país era aumentar a oferta de mão-de-obra na agricultura. Há que se considerar, contudo, que a maioria dos propagandistas da imigração defendia a importação de famílias, por serem mais estáveis. Outra questão pouco discutida pelos administradores são os gastos com o alojamento e transporte dos imigrantes. Afinal, se o número deles estava aumentando as despesas também, pois muitos chegavam doentes ou adoeciam na Hospedaria, o

\footnotetext{
${ }^{591}$ De maio a julho, teriam entrado na província e recolhidos ao alojamento provincial de imigração 1.005 imigrantes, sendo 683 italianos, 157 portugueses, 125 espanhóis, 33 alemães e 7 franceses. São Paulo. Relatorio com que passou a administração da Província de São Paulo ao Exm. Presidente Barão de Guajara' o Vice-Presidente Visconde de Itu. S. Paulo: Typ. do Commercio, 1883. p.20.

${ }^{592}$ São Paulo. Falla dirigida a Assembléa Legislativa Provincial de S. Paulo na abertura da $1^{a}$ Sessão da $25^{a}$ legislatura Em 16 de janeiro de 1884 pelo Presidente Barão de Guajará. S. Paulo: Typ. da "Gazeta Liberal", 1884. p.54-56.
} 
transporte de bagagens era caro e o alojamento consumia muito dinheiro devido à necessidade de reparos, de alimentar e acomodar os imigrantes.

Quanto à colônia João Bueno, criado pelo Governo Provincial com a doação que João Álvares de Siqueira Bueno fizera à Província de uma propriedade na freguesia de Guarulhos, o Barão de Guajará afirmou que outras famílias alemãs, recém-chegadas, haviam se instalado no local, nas mesmas condições das primeiras. O exemplo desta colônia, segundo o Administrador, aconselhava a aquisição de terrenos para a instalação de outros núcleos provinciais. Afinal, eles ressarciriam os cofres públicos das despesas realizadas e trariam grande benefício para a capital com a instalação da pequena lavoura. Nesse sentido, solicitou dos deputados provinciais a destinação de verbas para a abertura de uma estrada que fizesse a comunicação entre a Colônia João Bueno e a cidade. $^{593}$

Alguns meses depois, José Luiz de Almeida Couto, sucessor do Barão de Guajará na presidência, amparado numa lei aprovada pela Assembléia Provincial, constituiu duas comissões com a finalidade providenciar a criação de novos núcleos, denominando uma de Comissão do Norte e outra de Comissão do Oeste, numa referência às regiões da Província onde seriam instaladas as colônias. Inicialmente, seria criada uma colônia em cada região para servir de modelo às que se criariam posteriormente. A Comissão do Norte era formada por Manoel de Almeida Mello Freire, Raphel Dabney de Avellar Brotéro, Gregório José de Oliveira Costa, e Samuel Turner; a do Oeste, pelo Conde de Três Rios, Barão de Tatuhy e Francisco Antonio de Souza Queiroz Filho. ${ }^{594}$

\footnotetext{
${ }^{593}$ São Paulo. Falla dirigida a Assembléa Legislativa Provincial de S. Paulo na abertura da $1^{a}$ Sessão da $25^{a}$ legislatura Em 16 de janeiro de 1884 pelo Presidente Barão de Guajará. S. Paulo: Typ. da "Gazeta Liberal", 1884. p.54-56.

${ }^{594}$ São Paulo. Falla dirigida á Assembléa Legislativa Provincial de S. Paulo na abertura da $2^{a}$ Sessão da $26^{a}$ legislatura em 10 de janeiro de 1885 pelo Presidente Dr. José Luiz de Almeida Couto. S. Paulo: typ. da Gazeta Liberal, 1885. p.86-93. No século XIX, a região Norte correspondia ao Vale do Paraíba e a Oeste ao chamado Oeste Paulista. Os municípios que formavam o Vale do Paraíba eram: Taubaté, Redenção, São José dos Campos, Caçapava, Santa Isabel, Patrocínio de Santa Isabel, Jacaré, Santa Branca, São Bento do Sapucaí, São Luiz do Paraitinga, Lagoinha, Cunha Jambeiro, Lorena, Cruzeiro, Queluz, Areias, Silveiras, São José dos Barreiros, Bananal, Pindamonhangaba e Guaratinguetá e Mogi das Cruzes. Já o Oeste Paulista seria formado pelos municípios de: Campinas, Amparo, Serra Negra, Mogi Mirim, Penha do Rio de Peixe (atual Itapira), Pirassununga, Itatiba, Araras, Socorro, Rio Claro, Piracicaba, Capivari, Limeira, Araraquara, São Carlos do Pinhal (atual São Carlos), Brotas, Dois Córregos, Jaú, Jaboticabal, Santa Bárbara, Casa Branca, Mococa, Ribeirão Preto, Franca, Santa Rita do Paraíso, Descalvado, São João da Boa Vista, Cajurú, Batataes, Espirito Santo do Pinhal. Pela divisão eleitoral de 1881, os municípios do Vale do Paraíba correspondiam ao $2^{\circ}$. e $3^{\circ}$. distritos eleitorais, com
} 
Além de criar as comissões, José Luiz de Almeida Couto teria assinado contratos com Henri Rafard, Luiz Bianchi Betoldi e José Antonio dos Santos para a introdução de seis mil imigrantes; com Francisco Ferreira de Moraes para a introdução de dois mil; com R. Lobedans para a introdução de dois mil; e com a Companhia de Colonização Agrícola do Rio de Janeiro, para a introdução de setecentos e oitenta. ${ }^{595}$ No item relativo à imigração de seu relatório, o Inspetor Geral de Imigração João de Sá e Albuquerque apresentou um quadro geral da entrada de imigrantes na Província, demonstrando o "grande desenvolvimento imigratório" que se verificava em São Paulo. Além disso, elogiou a promulgação de algumas leis provinciais, em 1884 e 1885, que teriam simplificado pagamentos e restringido as possibilidades de especuladores agirem, prejudicando os cofres públicos e explorando a falta de recursos e ignorância de muitos imigrantes. ${ }^{596}$ Todavia, alguns daqueles contratos tiveram de ser rescindidos, ainda em 1885, pelo Presidente Elias Antônio Pacheco e Chaves, ${ }^{597}$ pois a Companhia de Colonização Agrícola do Rio de Janeiro, Henrique Raffard, Luis Bianchi Betholdi e José Antonio dos Santos não cumpriram o estipulado quanto ao número de colonos que deveriam introduzir. ${ }^{598}$

$\mathrm{O}$ aumento do fluxo de imigrantes foi acompanhado de uma série de medidas complementares. Uma delas consistiu em nomear para cargos de diretor das colônias

exceção apenas de Mogi das Cruzes, que pertencia ao $1^{\circ}$. Distrito; os do Oeste Paulista ao $7^{\circ}$., $8^{\circ}$. e $9^{\circ}$ distritos.

${ }^{595}$ São Paulo. Relatorio com que o Exm. Sr. Dr. José Luiz de Almeida Couto Presidente da Província de S. Paulo passou a administração ao $1^{o}$. Vice-Presidente, Exmo. Sr. Dr. Francisco Antonio de Souza Queiroz Filho. S. Paulo: Typ. do Correio Paulistano, 1886. p.26-29.

596 São Paulo. Relatorio com que o Exm. Sr. Dr. José Luiz de Almeida Couto Presidente da Província de S. Paulo passou a administração ao $1^{\circ}$. Vice-Presidente, Exmo. Sr. Dr. Francisco Antonio de Souza Queiroz Filho. S. Paulo: Typ. do Correio Paulistano, 1886. p. 27. Não obstante, ainda em 1885, Francisco Antônio de Souza Queiroz Filho, Vice-Presidente da Província, afirmou que o contrato firmado por José Luiz de Almeida Couto com a Companhia de Colonização Agrí́cola do Rio de Janeiro havia caducado, visto não ter a Companhia introduzidos, no prazo estipulado, os imigrantes a que se obrigara. São Paulo. Relatorio com que o Exm. Sr. Dr. Francisco Antonio de Souza Queiroz Filho Vice-Presidente da Província de S. Paulo passou a administração ao Vice-Presidente, Exm. Sr. Dr. Elias Antonio Pacheco e Chaves. S. Paulo: Typ. do Correio Paulistano, 1885.p.23-26

${ }^{597}$ São Paulo. Relatorio com que passou a administração da Província de S. Paulo ao Exmo. Presidente Conselheiro João Alfredo Corrêa de Oliveira o Vice-Presidente Dr. Elias Antonio Pacheco e Chaves. S. Paulo: Typ. do Correio Paulistano, 1885. p.17-22.

${ }^{598}$ Em 1886, João Alfredo Corrêa de Oliveira afirmou que, a Companhia de Transportes Marítimos de Marselha havia desembarcado 3.061 imigrantes no porto de Santos, mas apenas 433 permaneceram em São Paulo, devido o não cumprimento do contratos entre a Província e os empresários Henrique Raffard, Luiz Bianelú Betholdi, José Antunes dos Santos e Francisco Ferreira de Moraes. Em razão disso, tornou efetivas as multas em que os contratadores haviam incorrido e rescindiu os contratos. São Paulo. Relatorio apresentado a Assembléa Legislativa Provincial de São Paulo pelo Presidente da Província João Alfredo Corrêa de Oliveira no dia 15 de fevereiro de 1886. São Paulo: Typ. de Jorge Seckler \& C., 1886. p.33-41 
imigrantes que já estavam estabelecidos no país há mais tempo. Assim, o Inspetor Geral de Imigração, João de Sá e Albuquerque, informou que, havendo necessidade de uma pessoa que zelasse da colônia criada na fazenda Cascalho, em Lorena, nomeara o alemão Rodolph W. E. Voss, com a gratificação mensal de 120 réis, cujo trabalho seria fiscalizado pela Inspetoria de Imigração. ${ }^{599}$ Em outra colônia, o diretor escolhido seria italiano Luca de Strazzari, que além de fiscalizar os interesses do governo e dos colonos, prestaria serviços médicos a estes. ${ }^{600}$

A partir de 1886, uma nova forma de administração entrou em vigor. João Alfredo Corrêa de Oliveira criou "conselhos coloniais", formados por eleição entre os colonos. A experiência de outros países mostrava, segundo ele, que o imigrante se interessava verdadeiramente pelo progresso da colônia quando nisto se achava empenhada a sua responsabilidade, sistema muito mais profícuo ao desenvolvimento colonial do que a tutela do Estado. Esta prejudicava a iniciativa dos colonos, implantava a indiferença e a despreocupação no tocante ao que importava à comunhão, e, por mais esclarecida e provida que fosse, dava origem a queixas e exigências que perturbavam os intuitos de tais fundações.

Segundo Carlos H. Oberacker Junior, ${ }^{601}$ no Sul do Império, as colônias fundadas pelo Governo Geral e Provincial, bem como as particulares, quando não se restringiam à mera venda de lotes, diferenciavam-se do antigo sistema português por possuírem uma administração autônoma, sendo o diretor nomeado pelo governo ou pelo proprietário da gleba a colonizar. As funções do diretor eram supervisionar o loteamento, a distribuição dos lotes, a abertura das picadas, a construção de pontes etc., dispondo de poder militar, policial e até judicial. A partir de 1867, porém, um regulamento geral determinou a formação de conselhos administrativos, no qual os colonos tinham representação.

Estas medidas demonstram que os fazendeiros e as autoridades eram sensíveis às queixas dos colonos ou às pressões de agentes consulares, da imprensa e dos

\footnotetext{
${ }^{599}$ Isto não significa que todos os nomeados para dirigir colônias fossem estrangeiros, pois no mesmo relatório o presidente comunicou ter designado o Comendador Francisco de Paula Vicente de Azevedo para exercer o cargo de zelador e de depositário em outra delas. São Paulo. Relatorio com que o Exm. Sr. Dr. Francisco Antonio de Souza Queiroz Filho Vice-Presidente da Província de S. Paulo passou a administração ao Vice-Presidente, Exm. Sr. Dr. Elias Antonio Pacheco e Chaves. S. Paulo: Typ. do Correio Paulistano, 1885. p.23-26.

${ }^{600}$ Ibidem. p.17-22.

${ }^{601}$ OBERACKER JUNIOR, Carlos. Op. cit. p. 227.
} 
governantes dos países de onde provinham os imigrantes. As inúmeras greves, deserções e conflitos ocorridos desde as primeiras experiências com trabalhadores imigrantes demonstravam que uma política imigrantista só viria a ter sucesso caso as expectativas dos estrangeiros fossem atendidas, pelo menos em parte. Nas décadas de 1870 e 1880 era generalizada a opinião de que o europeu não admitia ser tratado como escravo e que os fazendeiros precisavam aprender a lidar com eles, fazendo concessões, pois do contrário as grandes propriedades se tornariam inviáveis. Sob este ponto de vista, havia uma relação estreita entre o que se passava nas colônias do governo e nas colônias particulares, pois os governantes se mostravam propensos a admitir a participação dos imigrantes na direção dos núcleos e em outras funções relacionadas com a recepção aos estrangeiros no porto de Santos e na Hospedaria de São Paulo.

Contrariando o pensamento da maioria dos presidentes que administraram São Paulo naquele período, João Alfredo Corrêa de Oliveira afirmou ser contrário à criação de núcleos coloniais oficiais. O melhor seria, segundo ele, que o governo ajudasse os proprietários de terras que quisessem estabelecê-los. Não obstante, poucos meses depois de fazer esta sugestão em seu relatório, João Alfredo assumiria a presidência do Conselho de Ministros e, durante sua gestão, vários núcleos coloniais foram criados e mantidos pelo Governo Imperial.

Para conseguir a corrente imigratória que São Paulo necessitava nada seria mais profícuo do que a intervenção dos proprietários dispostos a utilizar, por meio da venda, as terras que constituíam "vastos e desaproveitados domínios", bem como o empenho dos homens interessados no progresso da Província. Dessa forma se poderia ter na Europa uma propaganda "ativa e leal", que, "destruindo as prevenções e honrando" os créditos do Brasil, angariasse bons colonos, ou seja, aqueles que dispunham do pecúlio necessário para se tornarem pequenos proprietários ou os imigrantes que pudessem trazer o que a "ciência econômica" denominava "capital humano".

A imigração alemã era, segundo ele, uma das melhores a que podiam aspirar os países que precisavam de braços, e cuja excelência se afirmava pelos resultados que apresentavam as Províncias do Rio Grande do Sul e Santa Catarina. Os imigrantes 
“capazes de trabalho", que deixavam seus países para tentar uma melhor sorte, eram os que mais contribuíam para o desenvolvimento da colonização. ${ }^{602}$

Em 1887, o Barão de Parnahyba discutiu a criação dos núcleos coloniais sugeridos pela "Comissão do Norte" e pela "Comissão do Oeste", nomeadas pelo Presidente José Luiz de Almeida Couto. ${ }^{603}$ Antes, porém, fez uma digressão, criticando as pessoas que acreditavam na extinção da grande propriedade após a abolição da escravatura. Os deputados provinciais, segundo ele, também não concordavam com tais "utopias de reformadores europeus", tanto assim que estavam legislando em prol da grande lavoura. Sem ela a Província de São Paulo não teria estradas de ferro nem outras melhorias no seu sistema de transportes.

O pequeno proprietário, segundo o Barão de Parnahyba, era, em geral, "baldo de recursos" e, devido os "labores da vida" não cultivava seu espírito, não podia empreender grandes melhoramentos e reformas ou não tinha aptidão para tanto. Além disso, a aplicação da ciência à agricultura demonstrava a necessidade de se conservar a grande propriedade, pois os processos novos que substituíam o "trabalho primitivo" dependiam de grandes capitais e direção inteligente, que não estavam ao alcance dos pequenos proprietários. Era o que ocorria na Inglaterra e Alemanha, países da Europa onde a agricultura marchava "em grande escala na senda dos melhoramentos".

De acordo com o Barão de Parnahyba, as pessoas que preconizavam o fim da grande propriedade não levavam em consideração as circunstâncias em que se encontrava o país e, sem conhecimento de causa, afirmavam que as áreas ocupadas pelos grandes proprietários não seriam cultivadas nem vendidas. Segundo o Presidente, em São Paulo, as razões pelas quais não se desenvolvida a pequena propriedade eram outras. Havia abundância de terras férteis, por preços razoáveis, principalmente de terras apropriadas à cultura do café.

\footnotetext{
${ }^{602}$ São Paulo. Relatorio apresentado a Assembléa Legislativa Provincial de São Paulo pelo Presidente da Província João Alfredo Corrêa de Oliveira no dia 15 de fevereiro de 1886. São Paulo: Typ. de Jorge Seckler \& C., 1886. p. 33-41. De acordo com Sérgio Buarque de Holanda, após o fracasso do sistema de parceria adotado pelo Senador Vergueiro e outros fazendeiros, em meados do século XIX, ficou praticamente impossível obter mão-de-obra na Alemanha e Suiça, Todavia, por volta de 1887, quando se iniciava a imigração em massa, havia de doze mil a quinze mil alemães estabelecidos em São Paulo. HOLANDA, Sérgio Buarque. As colônias de parceria. Op. cit. p. 260.

${ }^{603}$ São Paulo. Relatorio apresentado a Assembléa Legislativa Provincial de São Paulo pelo Presidente da Província Barão do Parnahyba no dia 17 de janeiro de 1887. São Paulo: Typ. de Jorge Seckler \& Comp., 1887. p. 120-127.
} 
Os núcleos provinciais de Canas e Cascalho, criados a partir das sugestões da Comissão do Norte e da Comissão do Oeste, respectivamente, demonstrariam isso. Havia ali, segundo o Presidente, bons lotes e bem situados, porém poucos haviam sido vendidos. O motivo disso seria que o imigrante europeu não possuía dinheiro. Estes trabalhadores encontravam nas grandes propriedades casa, alimentação e todos os gêneros necessários para a sobrevivência de sua família. Após um ano já estariam aclimatados ao país e feito a aprendizagem necessária, já conheceriam o modo de trabalhar e até possuiriam alguma economia.

Portanto, a concepção do Barão de Parnahyba, muito comum entre as elites brasileiras da segunda metade do século XIX, era de que o imigrante europeu tinha uma propensão natural a se tornar proprietário. Seria, então, necessário atender a esta expectativa para que a política imigratória não fosse prejudicada, ou seja, que uma eventual frustração sua repercutisse na Europa, dando razão aos setores contrários à emigração para um país escravocrata. Entretanto, seria preciso contemplar também os interesses dos grandes proprietários em obter uma mão-de-obra barata, numerosa e disciplinada. A solução que o Administrador provincial vislumbrava contemplava ambos os interesses. Afinal, o imigrante primeiro venderia sua força de trabalho para os grandes proprietários, ocasião em que se adaptaria à cultura do novo país, e depois satisfaria a sua vontade. Para argumentar sua tese, o Barão de Parnahyba afirmou ser possível encontrar no Oeste da Província vários imigrantes que haviam chegado endividados ao país, mas depois saldaram seus débitos e adquiriram propriedades.

A análise do Presidente da Província legitimava, assim, a exploração do imigrante pelos grandes proprietários. Isto ficou claro, também, quando ele avaliou o método adotado naquele momento, ou seja, o pagamento pela capina e colheita dos cafezais, recebendo o colono uma área necessária para o plantio de gêneros alimentícios e a criação de animais, além de outras "regalias", considerando-o mais conveniente do que a parceria porque esta era muito mais conveniente ao colono do que ao proprietário. Não foi esta, porém, a conclusão dos estudiosos sobre ambos os sistemas. O sistema de pareceria se revelou prejudicial para os imigrantes, que viam sua dívida inicial aumentar ao invés de diminuir. Os fazendeiros não admitiam revisar os contratos e foram 
acusados de abusar nos preços dos produtos vendidos nos seus armazéns e de agir com má-fé nas transações comerciais de venda do café. ${ }^{604}$

Quando ao "serviço de imigração e colonização", o Barão de Parnahyba afirmou que, tendo em vista a nomeação de Frederico José de Araújo Abranches para o cargo de Delegado das Terras e Colonização em São Paulo, decidira também nomeá-lo para o cargo de Inspetor Geral de Imigração, a fim de facilitar e melhorar este serviço. ${ }^{605} \mathrm{O}$ fato de o ocupante dos cargos desempenhar suas funções gratuitamente, como assinalou o Presidente, não afasta os indícios de que se tratava de uma decisão deliberada no sentido de atrelar a questão da terra à de braços, conforme verificamos ao analisar o "Serviço de Catequese e Civilização dos índios", corroborando a conclusão de Manuela Carneiro da Cunha.

O acúmulo de cargos por parte de políticos ligados ao partido da situação era uma prática corrente. Da mesma forma, a aquisição de áreas destinadas à criação de núcleos coloniais e a distribuição de lotes nos mesmos continuava gerando suspeitas. Ao atender à sugestão da Comissão do Oeste para instalar uma colônia agrícola naquela área da Província, o então Presidente da Província, conselheiro José Luiz de Almeida Couto, adquirira uma fazenda denominada Cascalho, no município de Rio Claro, pertencente a Domingos José Nogueira Jaguaribe Filho, político ligado ao Partido Conservador e deputado provincial. ${ }^{606}$ Embora o Presidente tenha alegado que o proprietário reduzira o preço da fazenda porque desejava contribuir para a criação de um núcleo colonial no Oeste da Província, isto não atenua a possibilidade de que houvesse algum favorecimento na instalação do núcleo.

Segundo o Barão de Parnahyba, seu antecessor havia tomado as providências necessárias para a demarcação dos lotes, porém o preço destes constituiria um embaraço

\footnotetext{
${ }^{604}$ DEAN, Warren. Op. cit. p. 102-103.

${ }^{605}$ São Paulo. Relatorio apresentado a Assembléa Legislativa Provincial de São Paulo pelo Presidente da Província Barão do Parnahyba no dia 17 de janeiro de 1887. São Paulo: Typ. de Jorge Seckler \& Comp., 1887. p. 124.

${ }^{606}$ São Paulo. Relatorio apresentado a Assembléa Legislativa Provincial de São Paulo pelo Presidente da Província Barão do Parnahyba no dia 17 de janeiro de 1887. São Paulo: typ. de Jorge Seckler \& Comp., 1887. p. 125. Segundo Jeffrey Lesser, Domingos Jaguaribe Filho, cujo pai era Senador, se declarava abolicionista e dizia que os escravos que possuía pertenciam à sua mulher. Em 1878, ele publicou um livro intitulado Reflexões sobre a colonização no Brasil, baseado em sua tese apresentada à Academia Imperial de Medicina, no qual descartava a possibilidade de serem introduzidos no país outro imigrante que não fosse o europeu, mesclando teorias pseudocientíficas sobre raça e cultura, brasileiras e européias. LESSER, Jeffrey. A Negociação da Identidade Nacional. Imigrantes, minorias e a luta pela etnicidade no Brasil. Trad. Patrícia de Queiroz C. Zimbres, São Paulo: Unesp, 2001. p. 53-55.
} 
à realização da idéia. Além de fazer uma nova demarcação, por considerar a anterior deficiente, o Presidente da Província afirmou que reduzira o valor dos lotes, nomeara um administrador e tomara outras medidas para "fazer vingar uma idéia de tanta utilidade quanta necessidade". O núcleo era formado por 69 lotes rurais, 52 suburbanos e 124 urbanos, os quais seriam ocupados por imigrantes dinamarqueses e suecos, prestes a chegar à Província. Até aquele momento, apenas 31 dos lotes rurais estavam ocupados.

Quanto ao núcleo Fazenda das Canas, localizado na região Norte da Província, ${ }^{607}$ mais especificamente no município de Lorena, o Barão de Parnahyba afirmou que o mesmo possuía 78 lotes rurais e 120 urbanos, com casas prontas à espera de imigrantes e que havia feito esforços para que colonos madeirenses se estabelecessem no local, onde poderiam se dedicar à cultura da cana. Porém, apenas nove lotes teriam sido ocupados, razão pela qual considerava que o núcleo de Rio Claro tinha melhores perspectivas de prosperidade. Alguns meses mais tarde, ao passar a administração da Província ao seu sucessor, o Presidente afirmou que autorizara o diretor do núcleo das Canas a admitir colonos nacionais, mediante carta de fiança ou pagamento à vista do valor dos lotes que lhes fossem vendidos. Esta decisão demonstrava que os imigrantes recém-chegados em São Paulo se dirigiam de preferência para a região Oeste ou para as proximidades da capital da Província. ${ }^{608}$

O Anexo 10 do relatório apresentado pelo Barão de Parnahyba em 1887,, ${ }^{609}$ continha o relatório do inspetor geral de imigração, Frederico José Cardozo de Araújo Abranches, que fez uma importante análise sobre o estágio em que se encontrava a política imigratória de São Paulo.

O sistema adotado pelas leis provinciais, segundo o inspetor, afastara-se do que até então fora seguido no Império, que era o aliciamento direto dos imigrantes, sob a responsabilidade do governo, por intermédio de contratadores. Assim, anteriormente, a colonização tinha um caráter coletivo, ou seja, era promovida pelos governos com o

${ }^{607}$ No século XIX as regiões Norte e Oeste, que posteriormente passaram a ser designadas por Vale do Paraíba e Oeste Paulista, respectivamente, tinham por referência a posição geográfica do país, e não os pontos cardeais.

${ }^{608}$ São Paulo. Exposição com que o Exm. Snr. Visconde do Parnahyba passou a administração da província de São Paulo ao Exm. Snr. Dr. Francisco de Paula Rodrigues Alves Presidente desta Província no dia19 de novembro de 1887. São Paulo: typ. de Jorge Seckler \& Comp., 1888. p. 126.

${ }^{609}$ ABRANCHES, Frederico José Cardoso de Araújo. Immigração. São Paulo. Relatorio apresentado a Assembléa Legislativa Provincial de São Paulo pelo Presidente da Província Barão do Parnahyba no dia 17 de janeiro de 1887. São Paulo: Typ. de Jorge Seckler \& Comp., 1887. Annexo 10. 
interesse de povoar suas possessões. Naquele momento, porém, a imigração era toda de natureza individual. O imigrante decidia deixar a terra onde nascera, na crença de melhorar, sendo atraído por aqueles que necessitavam da sua mão-de-obra. Para atraílos, estes últimos procuravam se tornar conhecidos com toda exatidão e lealdade, não ocultando o que tinha de mau, nem exagerando o que tinha de bom. Era indispensável que o imigrante soubesse quais as dificuldades teria no novo país, cujas condições físicas e morais diferiam das daquele que deixava. Nada seria mais fatal à colonização, de acordo com ele, do que as desilusões do imigrante que, chegando com a convicção de encontrar um Eldorado, via-se rodeado de tropeços, que não poderia superar senão após rude e assíduo trabalho. A realidade destruiria a energia do colono e abater-lhe-ia o ânimo de modo a ser muito difícil reerguê-lo.

Nesses casos, as queixas dos imigrantes desiludidos eram dirigidas ao governo que os mandara aliciar através de agentes. Esta era a principal origem da resistência de alguns países à emigração de seus compatriotas para o Brasil. O estrangeiro que se dispunha a imigrar para o Império devia chegar com a convicção de que encontraria "solo ubérrimo", mas que não produzia sem trabalho. Devia se compenetrar de que não o esperava uma vida só de gozos, mas também de labor, que era preciso regar a terra com seu suor antes de colher a desejada messe.

Não bastava o emigrante tomar passagem em um paquete, tendo por bagagem um "saco de ilusões". Primeiramente, importava ter a firme resolução de trabalhar. No Brasil, como em Paris, não se enriquecia em oito dias, não se apanhava ouro nas estradas, nem diamantes: lá, como em toda parte, era preciso trabalhar para obter-se resultado. Assim, o incentivo à imigração era o interesse individual, o desejo de melhorar de posição. Em razão disso, toda a ação dos poderes públicos devia ser voltada para tornar conhecida no exterior a Província de São Paulo, a amenidade do seu clima, a fecundidade de suas das terras e, finalmente, a proteção e agasalho com que se deparariam os que nela chegassem. Era justamente o que se estaria fazendo em S. Paulo, principalmente com o auxílio da Sociedade Promotora de Imigração, que, além de outros serviços, acabava de promover a publicação, em diversas línguas, de um opúsculo para ser distribuído em todos os "focos de emigração" européia.

Quanto aos núcleos coloniais existentes em São Paulo, o inspetor afirmou que o desenvolvimento não era proporcional aos sacrifícios feitos pela Província. Isso 
porque o imigrante que chegava à Província era em geral homem pobre, destituído de meios para se manter, do preparo da terra até a colheita. Além disso, o espírito do imigrante seria "naturalmente suspeitoso" e a dúvida mataria a crença no futuro. O imigrante queria ter a certeza de poder contar com recursos que o mantivessem até que o solo "ubérrimo e luxuriante" da Província restituísse o seu tesouro, ou seja, o trabalho. Tais recursos podiam ser supridos pelo governo, dando aos colonos serviços nos primeiros meses de seu estabelecimento, de modo a poderem dedicar-se à cultura própria e a angariarem meios para acorrerem às urgentes necessidades da vida. Estes serviços deviam ser aplicados em construções de estradas e outros melhoramentos que as colônias constantemente necessitavam.

Vozes como a do Inspetor de Colonização e Imigração se erguiam, vez por outra, para propor a utilização do braço livre nacional no lugar do emprego de imigrantes europeus. Um relatório do engenheiro Joaquim Rodrigues Antunes Junior, Presidente da Comissão de Colonização, datado de 7 de novembro de 1886 e publicado no mesmo relatório do Barão de Parnahyba, apresentou os resultados de uma inspeção e recenseamento dos núcleos coloniais existentes nas proximidades da capital da Província. ${ }^{610}$ Baseado nos dados que colheu, o engenheiro recomendou um melhor aproveitamento dos núcleos emancipados, especialmente os de Sant'Anna, S. Caetano e S. Bernardo, que segundo ele dispunham de muitos lotes vagos para o estabelecimento de imigrantes e colonos nacionais.

Não havia, portanto, diferença significativa entre as colônias provinciais e imperiais. Mas é importante assinalar que este sistema coexistiu com a chamada “imigração espontânea”, apesar das inúmeras críticas que recebia, sobretudo dos órgãos de imprensa ligados ao Partido Republicanos e demais setores que não concordavam com a ingerência no governo no assunto além da subvenção de passagens e outros incentivos aos fazendeiros. Esta e outras críticas foram, posteriormente, reiteradas pelos estudiosos. Chiara Evangelista, baseando-se também nas considerações de Celso Furtado, afirmou que os núcleos coloniais instalados em São Paulo não tiveram

610 ANTUNES JUNIOR, Joaquim Rodrigues. Comissão de Colonização. In: São Paulo. Relatorio apresentado a Assembléa Legislativa Provincial de São Paulo pelo Presidente da Província Barão do Parnahyba no dia 17 de janeiro de 1887. São Paulo: typ. de Jorge Seckler \& Comp., 1887. Annexo 11, "Colonisação". 
resultados positivos, nem para fins de povoamento e criação de pequena lavoura, nem para o desenvolvimento da plantação. ${ }^{611}$

Para estes autores, todo o problema reside no fato de que, quando o governo deixava a colônia entregue à sua própria sorte, elas tendiam a se definhar, "involuindo em simples economia de subsistência". ${ }^{612}$ Esta visão consagra como "resultado positivo" para as colônias apenas a sua inserção no mercado como produtora de gêneros agrícolas ou fornecedora de mão-de-obra para a grande lavoura agro-exportadora. Sob este ponto de vista podemos considerar a experiência um fracasso, tanto em São Paulo como no Pará. Entretanto, não foi esta a perspectiva que procuramos ressaltar aqui.

Ao discutirem, implementarem e criticarem a criação de núcleos coloniais, os agentes históricos evidenciaram suas concepções acerca de uma série de questões relacionadas com o processo de reorganização do mercado de trabalho no Brasil. Entre elas, destacamos a projeção de imagens sobre o trabalhador ideal, aquele que deveria promover a prosperidade da nação e, conseqüentemente, garantir a manutenção do status quo. Está muito claro em todo o debate sobre a imigração e colonização que os grupos dominantes, tanto de São Paulo como do Pará, aceitavam, até certo ponto, negociar a identidade nacional, mas não cogitavam promover transformações mais profundas na estrutura econômica, social e política do país.

\subsection{Unindo esforços}

Em 5 de dezembro de 1883, o jornal A Província de São Paulo publicou um artigo no qual afirmava que os paulistas tinham a mania de criar associações e "matálas" antes do tempo. O redator se referia a uma associação criada para desenvolver a imigração, intitulada "Sociedade de Imigração", que não chegara sequer a ser instalada. Era necessário, segundo ele, que o desejo de obter braços livres para substituir os escravos não ficasse somente em palavras. Nesse sentido, conclamava a união de esforços para que ele fosse uma realidade. Em seguida, referindo-se à criação, na Corte, da "Sociedade Central de Imigração", afirmou que seria oportuno rever os estatutos da associação que malograra e constituí-la de acordo com a que se fundava no Rio de

${ }^{611}$ EVANGELISTA, Chiara. Os Braços da Lavoura. Imigrantes e "caipiras" na formação do mercado de trabalho paulista (1850-1930). Trad. Thei de Almeida V. Bertorello. São Paulo: Hucitec, 1991. p. 52.

${ }^{612} \mathrm{O}$ trecho é de Celso Furtado. Formação Econômica do Brasil. Ibidem. Loc. cit. 
Janeiro. Entre as vantagens desta, destacou a organização de um "plano de propaganda", que poderia dar resultados práticos para as províncias. Mesmo porque a Sociedade Central tinha interesse em criar filiais para auxiliá-la na "grande obra" de "chamar braços livres e válidos" para o "arroteamento das terras e exploração de todas as outras indústrias". 613

A sugestão do redator do jornal republicano seria atendida poucos anos depois. Em 1887, o Presidente da Província, Barão de Parnahyba, ${ }^{614}$ afirmou que contratara com a Associação Promotora da Imigração a introdução de seis mil imigrantes em São Paulo. Esta associação, fundada pouco antes, era dirigida por alguns dos principais cafeicultores da Província: Martinho Prado Junior, Nicolau de Souza Queiroz e Rafael de Aguiar Paes de Barros. Suas relações com o Barão de Parnahyba foram tão estreitas, que este propôs que o governo entregasse aos cuidados da Associação todos os assuntos relacionados com a introdução de imigrantes em São Paulo. Além disso, ele incluiu em seus relatórios os da própria Associação, como se ela efetivamente fizesse parte de sua administração.

Uma das primeiras medidas suas foi a abertura de inscrições para os imigrantes que quisessem se estabelecer em São Paulo, a convite de parentes que já residiam na Província. De acordo com o Administrador, o resultado da iniciativa foi um "avultado" número de pedidos, muitos deles recebidos de imigrantes dispostos a viajar imediatamente, mas impedidos de embarcar porque os portos brasileiros não estavam fechados aos navios procedentes da Itália em razão da epidemia de cólera que havia em algumas partes da Europa.

Entretanto, a proibição foi logo suspendida e a Associação enviou um representante à Itália e Alemanha para fazer propaganda imigratória. Para tanto, providenciara a publicação de um folheto, subsidiada pelo Ministério da Agricultura, intitulado A Província de São Paulo no Brasil, com tiragem de sessenta mil exemplares, traduzidos para o italiano e alemão. O Barão de Paranhyba afirmou que acreditava ser possível entregar à sociedade todo o serviço referente à imigração, assim que ficasse concluído o prédio da Hospedaria de Imigrantes que estava em construção.

\footnotetext{
${ }^{613}$ SOCIEDADE de Imigração, A Província de São Paulo, 05/12/1883, [Editorial].

${ }^{614}$ São Paulo. Relatorio apresentado a Assembléa Legislativa Provincial de São Paulo pelo Presidente da Província Barão do Parnahyba no dia 17 de janeiro de 1887. São Paulo: typ. de Jorge Seckler \& Comp., 1887.
} 
Mais tarde, ao passar a administração da Província para Francisco de Paula Rodrigues Alves, o Visconde de Parnahyba. ${ }^{615}$ estimou que em 1887 cerca de trinta e dois mil imigrantes haviam chegado à Província, número que ele considera muito "lisongeiro e satisfatório", mas aquém das necessidades locais. Em razão disso, firmara contrato com a Sociedade Promotora de Imigração para a introdução de mais trinta mil imigrantes. A associação, que já teria cumprido um contrato introduzindo seis mil imigrantes, teria firmado um contrato com o Ministério da Agricultura, pasta ocupada pelo conselheiro Antonio da Silva Prado, visando a introdução de 500 famílias, que seriam colocadas nos estabelecimentos agrícolas, conforme "favores" estabelecidos na Lei de 28 de Setembro de 1885.

De acordo com o Barão de Parnahyba, a Sociedade prestava relevantes serviços à "nobre causa" da imigração e Martinho da Silva Prado Júnior, diretor da Sociedade, era "o propagador mais ardente da imigração" que, possuindo estudos especiais, fortalecidos por viagens à Europa, dera grande auxílio à administração. Estes elogios do Barão de Parnahyba a um político do Partido Republicano é significativo, pois revela que a elite paulista, apesar de algumas divergências, estava convergindo seu pensamento para o sentido da promoção da imigração européia. As divergências sobre a procedência do imigrante e o envolvimento do Estado já pareciam ter sido amenizadas àquela altura. Entretanto, era preciso cuidar para que fossem recrutados trabalhadores disciplinados e que viessem efetivamente para trabalhar nas lavouras.

Nesse sentido, o Barão de Paranhyba recomendou à Assembléia Legislativa Provincial que aprovasse uma medida exigindo que o auxílio aos imigrantes fosse concedido apenas àqueles que se destinassem à lavoura, nas fazendas ou nos núcleos coloniais. O mais conveniente, segundo ele, era que fossem atraídos para a Província pessoas habituadas aos trabalhos do campo, que tivessem sido chamados por parentes já estabelecidos em São Paulo e através da Sociedade Promotora da Imigração. Pagar indistintamente e, não raro, sem critério a todos aqueles que chegassem à Província para "procurar fortuna", sem se interessar pelo trabalho rural, acabaria por atrair apenas “elementos cosmopolitas" que causariam desordens na sociedade. A Sociedade, afirmou o Administrador, era composta de cidadãos importantes, que tinham por único

${ }^{615}$ São Paulo. Exposição com que o Exm. Snr. Visconde do Parnahyba passou a administração da província de São Paulo ao Exm. Snr. Dr. Francisco de Paula Rodrigues Alves Presidente desta Província no dia19 de novembro de 1887. São Paulo: typ. de Jorge Seckler \& Comp., 1888. 
objetivo a prosperidade e o futuro da Província, sem auferir o menor interesse, sendo merecedora, portanto, de "ampla e ilimitada confiança". ${ }^{616}$

Concomitantemente às providências para realizar a propaganda imigratória na Europa, a Administração Provincial de São Paulo tomava outras no sentido de recepcionar aqueles que chegavam, cuidando do seu transporte, hospedagem e sustento até que firmassem contratos de trabalho. Numa demonstração de que o número de imigrantes que chegava era cada vez maior, o Presidente da Província solicitou à Sociedade Promotora de Imigração, atendendo a uma requisição do superintendente da Companhia de Estrada de Ferro de Santos a Jundiahy, para que não desembarcassem dos paquetes os imigrantes chegados ao porto de Santos após as 14 horas e que tivessem como destino a capital da Província. Esta medida visava, provavelmente, evitar o acúmulo de imigrantes na estação da estrada de ferro em Santos. ${ }^{617}$

A maioria dos imigrantes introduzidos no país pela Sociedade Promotora da Imigração, nos seus primeiros anos de funcionamento, foi de pessoas que tinham parentes ou amigos em São Paulo. Conforme explicaram os diretores da Sociedade, em Relatório anexado pelo Visconde do Parnahyba, ${ }^{618}$ esta diretriz estaria contribuindo para diminuir os casos de colonos que se arrependiam de ter emigrado. Já os que chegavam espontaneamente em S. Paulo, "seduzidos por promessas exageradas dos agentes recrutadores", e recrutados sem nenhum critério viriam apenas à procura de fortuna e ao acaso. $^{619}$

A Sociedade Promotora propôs, então, aos deputados provinciais a concessão de passagens gratuitas somente para os que fossem introduzidos por ela. Isso, segundo o diretor, faria com que apenas imigrantes "bons e aptos para levantar-lhe o nível moral e industrial" se estabelecessem na Província. Outra proposta, mas para o governo geral,

\footnotetext{
${ }^{616}$ Ibidem. p. 127

${ }^{617}$ Outra resolução importante de meados da década de 1880 e que pode ser considerada decisiva para o estabelecimento da imigração em massa foi a construção de um novo prédio para instalar os imigrantes na capital da província. A Hospedaria de Imigrantes reduziu em muito as reclamações dos imigrantes, pois oferecia condições de se instalar adequadamente até que fossem contratados por fazendeiros.

${ }^{618}$ Relatorio apresentado ao Illm. e Exm. Snr. Visconde do Parnahyba, Presidente da Província de São Paulo pela Sociedade Promotora de Imigração. In: São Paulo. Exposição com que o Exm. Snr. Visconde do Parnahyba passou a administração da província de São Paulo ao Exm. Snr. Dr. Francisco de Paula Rodrigues Alves Presidente desta Província no dia 19 de novembro de 1887. São Paulo: typ. de Jorge Seckler \& Comp., 1888. p. 1-12. A diretoria da Sociedade Promotora de Imigração, que assinou o Relatorio, era composta por: Martinho Prado Júnior, Nicoláo de Souza Queiroz e Raphael Aguiar Paes de Barros.

${ }^{619}$ Ibidem. p. 6-7.
} 
era de que fosse adotado em todo o país o modelo seguido em São Paulo de conceder favores somente a imigrantes que possuíam famílias e não importar menos do que $90 \%$ de famílias de agricultores, de preferência aqueles chamados por parentes ou amigos que já residiam no país.

Os contratos firmados pelo governo geral, segundo o diretor, não estabeleciam restrições quanto à condição moral dos imigrantes, capacidade para o trabalho na agricultura e situação familiar, visando apenas introduzir o maior número deles. Além disso, os contratadores envolviam nos negócios agentes com má reputação na Europa. Segundo o diretor, agindo dessa forma, o Governo Imperial continuaria "desmoralizando" a "causa da imigração", e São Paulo se veria na "dura contingência" de ter de fazer propaganda exclusivamente sua, hostilizando a do governo geral, para escapar do "seguro naufrágio" com que ele ameaçava os paulistas, com sua imprevidência.

Quanto à nacionalidade, a predileção dos fazendeiros seria pelos trabalhadores italianos, que se adaptavam perfeitamente, pela "moralidade e inexcedível amor ao trabalho", aos desejos dos paulistas. Além disso, do ponto de vista econômico, a imigração italiana era vantajosa devido o preços das passagens serem mais baixos do que os de outra procedência. Haveria cerca de cem mil italianos estabelecidos na Província, os quais estariam ocupados em vários tipos de trabalho, "relativamente felizes e bem aceitos". Mas o diretor da Sociedade calculava que a Província necessitava de mais 100 mil imigrantes. ${ }^{620}$

De acordo com Zuleika Maria Forcione Alvim, os italianos representaram 42\% de todos os grupos que se dirigiram para o Brasil entre 1870 e 1920, totalizando cerca de 1,4 milhões de indivíduos. ${ }^{621}$ Este contingente se concentrou principalmente em São Paulo, Rio Grande do Sul, Paraná e Santa Catarina devido, em parte à política governamental de promover o povoamento de áreas fronteiriças e à demanda dos fazendeiros por trabalhadores para suas lavouras, mas também à situação particular da Itália. Um crescimento demográfico sem precedentes no século XIX, aliado a condições naturais difíceis, que desde o período napoleônico levava agricultores a buscar trabalho

\footnotetext{
${ }^{620}$ Os diretores da Sociedade Promotora de Imigração, assim como alguns administradores da província, calculavam em cerca de cem mil o número de escravos existentes em São Paulo, o que significa que provavelmente a estimativa tinha em vista a substituição dos escravos existentes por imigrantes.

${ }^{621}$ ALVIM, Zuleika Maria Forcione. O Brasil Italiano (1880-1920). In: FAUSTO, Boris (org.). Fazer a América. A imigração em massa para a América Latina. São Paulo: Edusp, 1999. p. 383.
} 
nas regiões ou na Europa central, durante o inverno, bem como o avanço da tecnologia e o melhoramento dos transportes, colocou à disposição no mercado de trabalho da península itálica verdadeiras hordas de camponeses sem terra e desocupados. ${ }^{622}$

Em seu Relatório, os diretores solicitaram que o governo subvencionasse apenas as passagens dos imigrantes que chegassem à Província por seu intermédio. $\mathrm{O}$ método empregado a partir de então, segundo Zuleika Alvim já havia sido adotado com sucesso nos núcleos coloniais em Santa Catarina e Rio Grande do Sul, ou seja, o de pagar as passagens diretamente às companhias de navegação, eliminando assim agentes que não tinham compromisso com os interesses dos fazendeiros. ${ }^{623}$ Mas o principal expediente utilizado foi o de contratar apenas familiares, parentes e amigos de pessoas já estabelecidas no país. Dessa forma, o imigrante chegava ao país com alguma idéia do que iria encontrar pela frente e contando com uma estrutura familiar ou uma rede de conhecidos capazes de ampará-lo no difícil período de adaptação.

Em seu relatório de 10 de janeiro de 1888, Francisco de Paula Rodrigues Alves calculou em 107 mil o número de escravos existentes na Província, mas este número diminuía rapidamente devido às libertações que ocorriam diariamente e em números expressivos. Ainda assim, a maior parte daquele contingente trabalhava na agricultura, o que significava que a abolição final provocaria um grande abalo no país. Não era natural, segundo ele, nem se podia esperar que os escravos, adquirindo a liberdade, permanecessem nos estabelecimentos agrícolas se dedicando aos rudes serviços da lavoura. Uma modificação do sistema de trabalho, como o pagamento de salários, acompanhada de esforços dos proprietários poderiam fazer com que muitos libertos, mesmo se deslocando das fazendas em que haviam vivido quando escravos, continuassem aprestar serviços à lavoura.

Todavia, a maior parte, segundo o Presidente, pelo menos no primeiro período da libertação, fugiria ao trabalho, entregando-se ao ócio e à vadiagem. Este deslocamento de trabalhadores provocaria a desorganização de muitos estabelecimentos agrícolas, sobretudo dos que pertenciam a proprietários que não dispunham de atividade

\footnotetext{
622 Ibidem. p. 384.

${ }^{623}$ Ibidem. p. 395. Segundo a autora, o agente mais importante da Sociedade era Caetano Pinto, já conhecido pela introdução de italianos no Sul, cujo contrato o autorizava a prometer, em seus folhetos de propaganda, que os imigrantes receberiam passagem gratuita do porto de desembarque à localidade escolhida como destino, sementes, alimentos por mais de seis meses e ainda a possibilidade de se tornarem proprietários.
} 
e de crédito para procurarem novos "agentes de trabalho" e proverem as necessidades da primeira colocação. Em alguns municípios, a substituição dos escravos por imigrantes europeus se faria naturalmente, mas em outros custaria "penosos sacrifícios", pois os proprietários não encaravam com o devido interesse a "momentosa questão" ou confiavam que a extinção da escravatura se faria pela ação normal das leis existentes. Mas a maioria, segundo o Presidente, nada fazia porque lhes faltava crédito para promover a substituição, dado que suas terras depauperadas não ofereciam remuneração suficiente e proporcional ao trabalho. De acordo com o Administrador, os deputados podiam colaborar dando ao Governo os "meios de tranquiilizar" os produtores e garantir os direitos de cada um, além de continuar favorecendo a introdução de trabalhadores estrangeiros. $^{624}$

Diante a iminência da abolição final, o Presidente afirmou que nenhum dos serviços a cargo do governo inspirava, naquele momento, mais interesse do que o da imigração. Em São Paulo, segundo ele, o movimento emancipador se acelerava e todos compreendiam as vantagens da substituição do escravo pelo imigrante. Antecipando-se ao problema, há muito tempo os legisladores aprovavam leis para promover a imigração e os partidos políticos davam tréguas às lutas, unindo-se no "pensamento patriótico" de fomentar o desenvolvimento e grandeza da Província.

A grande necessidade da lavoura, afirmou o Presidente, era o trabalhador para substituir os braços que "desapareceriam". Se o imigrante encontrasse nas fazendas terras para cultivar, trabalho que lhe garantisse um salário justo e condições satisfatórias de sobrevivência logo conseguiria se tornar proprietário, caso fosse esta a sua vontade.

Mencionando uma estimativa da Sociedade Promotora da Imigração, afirmou que seria necessária a introdução imediata de mais cem mil imigrantes. Só do Norte da Itália, existiriam no escritório da Sociedade cartas, pedindo passagens para mais de cinqüenta mil pessoas, acompanhadas das listas nominais com a procedência, estado civil, sexo e idade. Todavia, por não serem indicados por parentes ou amigos estabelecidos em São Paulo este contingente seria preterido. A Província tinha à sua disposição, prontos para embarque imediato, cerca de setenta mil italianos, constituindo famílias, todos camponeses agricultores, que suplicavam a caridade lhes serem enviados

\footnotetext{
${ }^{624}$ São Paulo. Relatorio apresentado a Assembléa Legislativa Provincial de São Paulo pelo Presidente da Província Snr. Dr. Francisco de Paula Rodrigues Alves no dia 10 de janeiro de 1888. São Paulo: typ. de Jorge Seckler \& Comp., 1888. p.15-22.
} 
bilhetes gratuitos de passagem. Mas a Sociedade, sempre cautelosa, não pretendia ultrapassar a linha de conduta que traçara para seus atos, limitando-se sempre aos chamados e na medida de suas necessidades, ou seja, da demanda por trabalhadores.

Todavia, a administração encontrara irregularidades cometidas no serviço de imigração. A imprensa da capital da Província, a Sociedade Promotora e agentes de imigração haviam feito reclamações contra o modo como era realizado o serviço de conferência das bagagens dos imigrantes, na hospedaria, quando eram apreendidos objetos de pequeno valor, mas de utilidade para os recém-chegados. Outro problema dizia respeito à aglomeração de imigrantes na Hospedaria. O Presidente solicitava cuidados especiais com a higiene do estabelecimento e a manutenção do atendimento médico preventivo, conforme estabelecia o regulamento do local.

De acordo com Francisco de Paula Rodrigues Alves, ao assumir a presidência, a situação parecia-lhe muito grave, sobretudo pelas ameaças de perturbação da ordem publica em grandes zonas do seu território. A Província entrara em uma fase "especialmente melindrosa", a exemplo do que ocorrera em outros países às vésperas da abolição da escravatura. Em uma reunião de fazendeiros efetuada em São Paulo, no dia 15 de dezembro de 1887, com o objetivo de "dar impulso e direção ao movimento emancipador", ficara assentado o prazo máximo de três anos para a abolição. Todavia, antes que a comissão incumbida de executar as deliberações da assembléia organizasse as bases do seu trabalho, os acontecimentos haviam se precipitado. Em vários municípios, ao mesmo tempo, os escravos abandonaram em massa as fazendas, procurando, a principio, abrigo no município de Santos, colocando-se depois nas localidades vizinhas, e não raro, à vista dos seus próprios senhores.

Os proprietários, segundo o Administrador, não procuravam, em regra, os escravos que fugiam. Estes, por seu turno, saíam pacificamente, sem "exasperar" os senhores, para não suscitarem resistências ou provocarem reações. Diante de tão serio movimento que, no início o enchera de preocupações, o Presidente afirmou que sua atitude fora de vigilância e de prudência, defendendo os proprietários no terreno legal, quando eles solicitavam o apoio das autoridades, mas tendo principalmente em vista manter a ordem pública.

Uma das conseqüências dessa "grande agitação", segundo o Presidente, foi a multiplicação do número de alforrias. Os fazendeiros, que até então manumitiam seus 
escravos com a cláusula de prestação de serviços por três anos e, mais tarde, apenas com a obrigação de fazerem eles a colheita pendente, acabaram por verificar que tais concessões eram insuficientes. Em razão disso, passaram a conceder alforria imediata e incondicional, oferecendo salários os libertos.

Franscisco de Paula Rodrigues Alves discutiu também a agricultura ou, mais especificamente, a produção cafeeira. A safra de 1887, segundo ele, havia sido "minguada", mas havia muitas plantações novas, cuja produção poderia em pouco tempo superar os efeitos da crise provocada pela transformação do trabalho e das grandes fugas de escravos. Por outro lado, sentia-se a necessidade de introduzir o cultivo de outros gêneros além do café.

Alguns belgas, recomendados pela Sociedade Central de Imigração, teriam procurado a presidência da Província, interessados em produzir trigo e do fumo. A videira também começava a prosperar em São Paulo. O Ministro da Agricultura enviara um questionário para verificação do desenvolvimento dessa cultura, o qual a administração dirigira a vários plantadores e fabricantes de vinho e Câmaras Municipais. Nos anexos do Relatório, incluiu um trabalho elaborado por Luiz Pereira Barretto. $^{625}$

O Presidente da Província, Rodrigues Alves, apresentou ainda o Relatório da "Comissão de Terras e Colonização", que estava a cargo do engenheiro Joaquim Rodrigues Antunes Junior. De acordo com a Comissão, a escassez de terras devolutas e de lotes disponíveis estava dificultando o recebimento de imigrantes que desejavam se estabelecer nos núcleos, principalmente naqueles situados próximos da capital. Entretanto, estava sendo possível colocar todos aqueles que haviam sido chamados da Europa por parentes já estabelecidos na Província. Além disso, fora iniciada a fundação de um novo núcleo, em terras devolutas, nas margens da Estrada de Ferro de Santos a Jundiai, próximo à estação de Ribeirão Pires. Em barracão ali construído já se achavam alojados 154 colonos.

Sobre imigração, o Presidente afirmou que um dos primeiros atos da Assembléia Provincial, na sessão daquele ano, fora autorizar o Governo a contratar, desde logo, a introdução de cem mil imigrantes de procedência européia, açoriana e

${ }^{625}$ São Paulo. Relatorio com que o Exm. Snr. Dr. Francisco de Paula Rodrigues Alves passou a administração da província de S. Paulo ao Exm. Snr. Dr. Francisco Antonio Dutra Rodrigues $1^{o}$. VicePresidente no dia 27 de abril de 1888. São Paulo: typ. de Jorge Seckler \& Comp., 1888.p.30-32. 
canarina, segundo as necessidades da lavoura e a boa localização dos trabalhadores livres. Em razão disso, celebrara contrato com a Sociedade Promotora de Imigração, em 29 de Fevereiro de 1888, para a introdução de sessenta mil imigrantes até o mês de dezembro. Havia, segundo ele, intensa procura por parte dos fazendeiros. Em vista dos acontecimentos verificados na Província, só mesmo um "movimento extraordinário", embora dispendioso, de imigração poderia salvar a lavoura de sérios desastres. Mas não se podia confiar exclusivamente no subsídio do braço estrangeiro. O liberto e o trabalhador nacional também eram "ótimos agentes de substituição dos escravos".

O Governo Geral e Provincial, por seu turno, esforçava-se para criar núcleos, onde o imigrante encontrava lotes medidos e demarcados, que podiam ser adquiridos em vantajosas condições. Assim, quando o regime de salário fatigasse o imigrante e o fazendeiro não tivesse o bom senso de facilitar-lhe a aquisição de terras para ter à mão os seus serviços, os núcleos poderiam recebê-los. Todavia, o Governo não podia criar núcleos coloniais em todos os municípios. Por esse motivo, recomendava que os fazendeiros desmembrassem suas propriedades e vendessem lotes para pequenos cultivadores. Dessa forma teriam, além do capital proveniente das vendas, trabalhadores para os auxiliarem no cultivo de sua lavoura.

Em 1888, o Presidente Pedro Vicente de Azevedo, ao passar a administração ao Vice-Presidente Rodrigues Alves, referiu-se à aprovação da Lei de 13 de maio de 1888, à qual se referiu como "a verdadeira libertação da pátria" e como uma "mancha" que empanava seus foros de nação civilizada. Segundo ele, havia ocorrido "espontâneas e ruidosas manifestações do jubilo", nas quais se congraçavam todas as classes sociais para solenizar o grande acontecimento que abrira novos horizontes ao engrandecimento do país. Embora essencialmente agrícola, a Província de São Paulo teria compreendido havia muito tempo que não era possível por mais tempo trilhar as tristes e ínvias estradas em que se estorcia a instituição condenada por todas as leis divinas e humanas. ${ }^{626}$

\footnotetext{
${ }^{626}$ São Paulo. Exposição com que o Exm. Snr. Dr. Pedro Vicente de Azevedo passou a administração da província de S. Paulo o exm. snr. Dr. Francisco Antonio Dutra Rodrigues $1^{o}$. Vice-Presidente no dia 23 de junho de 1888. São Paulo: typ. Baruel, Pauperio \& Comp., 1888.p.8.
} 


\subsection{Críticas à colonização oficial}

De acordo com os redatores do A Província de São Paulo, o fim da escravidão provocaria uma crise econômica. Não bastavam correr dos cofres públicos rios de dinheiro para atrair a imigração. Era preciso adotar leis mais eficientes para promover a organização do trabalho por meio da locação de serviços, elevar os salários e a incentivar o estabelecimento de pequenas propriedades. ${ }^{627}$ Outro problema seria a indiferença dos grandes proprietários, que não se preveniam perante a crise que ameaçava a agricultura. A imprensa, o parlamento, conferências públicas e até mesmo os relatórios oficiais discutiam o problema, mas os "lavradores" pareciam indiferentes a todo o debate. Algumas colônias particulares prosperavam, mas isto contribuía para remover os obstáculos à imigração de europeus. Os fazendeiros, em sua maioria, continuavam comprando escravos de outras províncias, para suprir a falta de braços. Mas a culpa era do governo, do regime de propriedade da terra, das leis econômicas que regulavam as relações sociais, particularmente no que se refere ao salário, e a falta de instrução dos agricultores. ${ }^{628}$

Os presidentes de província, por sua vez, procuravam assinalar nos relatórios e falas os esforços do governo e daqueles que o ajudavam a promover a imigração. De acordo com Sebastião José Pereira, por exemplo, somente "incessantes e supremos" esforços de todos promoveriam a colonização e imigração, salvando agricultura da "tempestade" iminente. A imigração e a colonização não prosperariam e não supririam de braços a lavoura caso se pretendesse fazer do imigrante um servo ou se o atirassem isolado no meio das florestas virgens. ${ }^{629}$

Mas para isso era preciso que o imigrante, ao chegar, não sentisse privações que lhe abatessem o ânimo. Se sua ambição era ser proprietário, convinha satisfazê-la, facilitando-lhe os meios de adquirir a propriedade territorial, em lugares onde pudesse achar fácil consumo aos frutos de seu trabalho. Uma vez estabelecido devia-se deixá-lo reger por si, desembaraçado de qualquer tutela. Nesse sentido, o Presidente solicitara ao Ministro da Agricultura a fundação de núcleos coloniais nas proximidades da capital e

${ }^{627}$ A NOVA fase, A Provincia de São Paulo, 02/07/1875, Seção Agrícola.

${ }^{628}$ A LAVOURA e as reformas, A Provincia de São Paulo, 29/12/1875, Seção Agrícola.

${ }^{629}$ São Paulo. Relatorio apresentado á Assembléa Legislativa Provincial de S. Paulo pelo Presidente da Província o Exm. Sr. Dr. Sebastião José Pereira em 6 de fevereiro de 1877. S. Paulo: Typ. do Diario, 1877. p.87-89. 
de outras localidades, para as quais eram mais fáceis os meios de comunicação. Em resposta, o Ministro enviara uma comissão para medir os terrenos devolutos existentes no município de Sorocaba, próximos à fabrica Ipanema, e autorizou a compra de duas fazendas pertencentes ao mosteiro de São Bento. Essas fazendas, assim como os "terrenos nacionais" da Glória e Santa Ana, seriam divididos em lotes destinados aos imigrantes. ${ }^{630}$

Naquele mesmo ano, porém, o jornal A Província de São Paulo denunciou que o governo estava beneficiando particulares na distribuição dos lotes dessa colônia, que recebeu o nome de Colônia Ipanema. ${ }^{631}$ O Um dos beneficiados seria o Presidente da Companhia Sorocabana de Estrada de Ferro. O jornal Diário de São Paulo, órgão oficial do Partido Conservador, que publicava os atos do governo, desmentia as acusações do redator do periódico republicano, mas este exigiu providências da Inspetoria Geral de Terras e Colonização para que a campanha em prol da imigração não fosse prejudicada. ${ }^{632}$

Além do favorecimento de pessoas ligadas ao governo, os republicanos acusavam que a Colônia Ipanema havia sido instalada em um "terreno estéril", "baldio de vegetação", o que prejudicaria os "incautos estrangeiros". 633 Aproveitando-se da situação, o jornal criticou o envolvimento do governo na questão do fornecimento de créditos aos fazendeiros e principalmente na colonização e imigração, afirmando que se tratava apenas de um pretextos para gastar dinheiro público em benefício de aliados políticos. $^{634}$

Em 1878, o redator do jornal A Província de S. Paulo afirmou que os contratos de imigração que o governo assinava com os agentes de imigração tinham por objetivo apenas "salvar as aparências". Isto porque tais contratos beneficiavam apenas os agentes, que introduziam no país "presidiários europeus", e não trabalhadores. O próprio Ministro da Agricultura teria reconhecido que era impossível fazer cumprir os contratos. ${ }^{635}$ Alguns anos mais tarde, o redator afirmou que governo não tinha uma política imigratória, agindo apenas conforme a pressão do momento ou as sugestões dos

\footnotetext{
${ }^{630}$ Ibidem.. p.87.

${ }^{631}$ TERRA a Colonos, A Provincia de São Paulo, 22/06/1877, [Editorial].

${ }^{632}$ Idem

${ }^{633}$ A COLONIA de Ipanema, A Provincia de São Paulo, 27/06/1877, [Editorial].

${ }^{634}$ O SISTEMA protecionista e a lavoura, A Provincia de São Paulo, 15/07/1877, [Editorial].

${ }^{635}$ IMMIGRAÇÃ̃, A Provincia de São Paulo.19/02/1878, [Editorial].
} 
interessados. ${ }^{636}$ O Congresso Agrícola de 1878, convocado pelo Ministro Cansansão de Sininbu também foi muito criticado, sobretudo as tentativas deste de promover a introdução de imigrantes chineses no país. ${ }^{637}$

Em 1880, quando tramitava um projeto de interesse do governo, autorizando despesas com a introdução de "coolies", o jornal republicano afirmou que o aproveitamento dos recursos seriam maior caso fossem destinados a ajudar os fazendeiros interessados em contratar colonos diretamente na Europa para seus estabelecimentos agrícolas. ${ }^{638}$ Mais tarde, o jornal criticou o pedido feito pelo Ministério da Agricultura aos presidentes das Províncias da Bahia, Pernambuco, S. Paulo, Rio de Janeiro e Maranhão para criarem escolas agrícolas naquelas Províncias. Segundo o redator, solicitações daquele tipo era uma forma de o governo "armar as simpatias dos lavradores", com o intuito de colher benefícios políticos, para depois abandoná-los. ${ }^{639}$ Por outro lado, algumas iniciativas do governo eram elogiadas. Ainda em 1880, o jornal saldou a decisão do governo de promover a "internação" em hospedaria na cidade de São Paulo, dos imigrantes recém-chegados ao país, reprovando desta vez as críticas que teriam sido feitas, pelo Jornal do Comércio e Gazeta de Notícias, ambos do Rio de Janeiro, à decisão tomada. ${ }^{640}$

Em 5 de fevereiro de 1881, o jornal A Província de S. Paulo criticou um projeto de lei que estava em tramitação da Assembléia Provincial, apesar de considerá-lo oportuno, afirmando ser "melindroso", pois, além de comprometer os cofres públicos, consagrava um "expediente econômico" muito combatido pelo jornal: a organização e custeio de empresas colonizadoras por parte do Governo. ${ }^{641} \mathrm{O}$ governo, segundo o redator, não devia utilizar recursos públicos para financiar empresas de imigração, mas reformar o "regime de trabalho agrícola", promover a transformação da grande lavoura, ou seja, incentivar o estabelecimento de pequenas propriedades. ${ }^{642}$

Isto não significa, contudo, que os redatores do jornal A Província de São Paulo preconizassem o fracionamento das grandes propriedades. Mantido por uma sociedade comanditária, da qual faziam parte alguns dos maiores produtores de café da região, o

\footnotetext{
${ }^{636}$ [Sem Título], A Provincia de São Paulo.29/01/1880, [Editorial].

${ }^{637}$ [Sem Título], A Provincia de São Paulo.04/02/1880, [Editorial].

${ }^{638}$ [Sem Título], A Provincia de São Paulo,10/02/1880, [Editorial].

639 [Sem Título], A Provincia de São Paulo, 08/05/1880, [Editorial].

${ }^{640}$ [Sem Título], A Provincia de São Paulo, 17/12/1880, [Editorial].

641 [Sem Título], A Provincia de São Paulo, 05/02/1881, [Editorial]

642 [Sem Título], A Provincia de São Paulo, 03/03/1881, [Editorial].
} 
periódico republicano pintava um cenário sombrio para o futuro do país sem o braço escravo, com o objetivo de convencer seus leitores que o Governo Imperial não seria capaz de evitar a catástrofe que se anunciava. Assim, ao mesmo tempo em que acusavam o governo de desperdiçar dinheiro público ao estabelecer contratos de colonização com empresas que visavam apenas a auferir lucros com a introdução de pessoas que não tinham experiência ou aptidão para trabalhar na agricultura, de beneficiar seus apaniguados com a cessão de lotes demarcados em colônias oficiais ou com a aquisição, por meio de desapropriações fraudulentas, de terras improdutivas e mal localizadas, os republicanos do jornal A Província de São Paulo acusavam também o governo de não ser capaz de solucionar o problema do suprimento de braços para as lavouras.

Assim, os redatores do jornal defendiam a "imigração espontânea", ou seja, aquela feita sem intervenção direta do governo. A introdução de trabalhadores europeus deveria se dar pela iniciativa particular de indivíduos ou através de associações sem fins lucrativos. ${ }^{643} \mathrm{Em} \mathrm{1881}$, por exemplo, ao noticiar a criação de uma sociedade protetora da imigração portuguesa na Província de S. Paulo, o redator afirmou que a idéia devia ser aplaudida por todos aqueles que desejavam a "imigração livre", "fonte de trabalhadores válidos, moralizados e pertinazes na exploração da indústria agrícola". ${ }^{644}$

Ainda naquele ano, em meio às notícias sobre a queda dos preços do café no mercado internacional, o jornal criticou o governo por tentar introduzir no país imigrantes chineses. ${ }^{645}$ Todavia, saudou o que chamou de início de uma "nova fase" na política imigrantista da Província, graças à iniciativa de um "distinto e laborioso brasileiro", residente em Paris, Argolo Ferrão, que havia fundado naquele país o jornal Le Brésil e se propunha a organizar uma associação anônima com o objetivo de promover a emigração de trabalhadores franceses para o Brasil. ${ }^{646}$

Em 14 de janeiro de 1883, o jornal elogiou os trabalhos da Sociedade Central de Geografia, sediada Berlim, que estaria promovendo a emigração de alemães para o Brasil. $^{647}$ Alguns meses mais tarde, o mesmo periódico comparou o serviço de imigração dos Estados Unidos com o existente no Brasil, concluindo que já era tempo

\footnotetext{
643 [Sem Título], A Provincia de São Paulo, 08/03/1881, [Editorial].

644 [Sem Título], A Provincia de São Paulo, 22/05/1881, [Editorial].

645 [Sem Título], A Provincia de São Paulo, 23/07/1881, [Editorial].

${ }^{646}$ [Sem Título], A Provincia de São Paulo, 20/11/1881, [Editorial].

${ }^{647}$ A IMMIGRAÇÃO Alemã, A Provincia de São Paulo, 14/01/1883. [Editorial].
} 
de "regularizar" o serviço no Brasil e dar-lhe outra direção, livrando o Estado da responsabilidade direta do acolhimento e sustento do imigrante por longos dias e meses. Estas tarefas deviam ser realizadas por uma associação, ainda que o Estado concedesse a ela "certos favores". 648

Em suma, os redatores do jornal A Província de São Paulo não eram totalmente contra o envolvimento do governo na introdução de trabalhadores europeus no Brasil. Eles admitiam a adoção de incentivos, como o pagamento de passagens e a estadia até que os imigrantes fossem contratados por fazendeiros, mas discordavam da compra de terras para a instalação de colônias oficiais e dos contratos com agências que, visando apenas o lucro, não tinham compromisso em recrutar o imigrante considerado ideal para o trabalho agrícola.

Em 22 de junho de 1882, o redator do jornal A Província de São Paulo argumentou que todos deviam se interessar pela solução do problema de fornecimento de braços para a lavoura e indústria, pois dele dependia várias questões de caráter político, econômico e administrativo. ${ }^{649}$ Dois anos mais tarde, outro editorial voltava a colocar em dúvida a sobrevivência da grande propriedade sem o braço escravo, assinalando que a "força" da mesma estaria na abundância de braços escravos, que seriam, em geral, mal aproveitados. Comprar lotes de negros, arregimentá-los no serviço, forçá-los ao trabalho com a autoridade despótica, absoluta de senhor, alimentálos, vesti-los e acomodá-los conforme as conveniências e circunstancias do lavrador eram, segundo o redator, condições que permitiam a posse de muitas terras e a má cultura da cana e do café em larga escala. Em seguida, o redator direcionou suas críticas para os partidos monárquicos e, principalmente, para a política colonizadora da Administração Provincial. Defendendo, mais uma vez, a "imigração espontânea", o redator afirmou que a colonização oficial só daria resultado se fossem mudados os "maus hábitos" de toda a administração, em especial das repartições fiscais, o que, obviamente, considerava impossível no regime monárquico. ${ }^{650}$

\footnotetext{
648 [Sem Título], A Provincia de São Paulo, 11/09/1883. Notas e Respigas.

649 [Sem Título], A Provincia de São Paulo, 22/06/1882, [Editorial].

${ }^{650}$ AUXILIOS a imigrantes, A Provincia de São Paulo, 21/02/1884, [Editorial].
} 


\subsection{De imigrante a trabalhador}

A análise acerca dos debates sobre a imigração e colonização em São Paulo, pelo menos aquela efetuada a partir dos principais jornais, relatórios e falas dos presidentes que administraram a Província, demonstra que fazendeiros e políticos foram paulatinamente substituindo idealizações por soluções pragmáticas. Esta tendência é facilmente perceptível se acompanharmos as discussões sobre a origem dos trabalhadores. No início da década de 1870, por exemplo, o Barão de Indaiatuba se dirigiu à Europa na expectativa de contratar alemães, mas teve de se contentar com trabalhadores da região do Tirol. O italiano, geralmente preterido naquele período, foi saudado como a salvação das lavouras de café a partir de meados da década de 1880 .

O mesmo pode ser dito em relação ao debate sobre imigração e colonização. Entre o final da década de 1870 e o início da seguinte, o jornal A Província de São Paulo publicou vários artigos criticando a criação de núcleos coloniais e até mesmo a contratação de agências de imigração pela administração provincial, por considerá-las um meio de favorecimento de aliados políticos. Por volta de 1886, no entanto, os conservadores criram vários núcleos coloniais na Província, recendo poucas críticas de seus adversários.

Ao mesmo tempo, medidas pragmáticas, visando atrair imigrantes e facilitar a sua adaptação na Província eram colocadas em prática sem muitas divergências. No que se refere aos núcleos, a principal delas foi deixá-los cada vez mais sob o controle dos próprios colonos; em relação à chamada "imigração espontânea" o expediente que pode ser considerado fundamental para a solução de muitos problemas ocorridos nas décadas anteriores foi a concessão de subsídios para familiares e amigos de trabalhadores estrangeiros já estabelecidos em São Paulo.

Este conjunto de medidas revela que os envolvidos na política de colonização e imigração estavam menos propensos a buscar um tipo ideal de trabalhador, projetando nele imagens que diziam respeito mais aos trabalhadores existentes no país do que propriamente ao estrangeiro. Não é fácil encontrar explicações para esta mudança. É possível que a perspectiva da abolição da escravatura, provocada pelo recrudescimento da pressão abolicionista, tenha contribuído para que redatores de jornais e políticos 
buscassem encontrar soluções mais rápidas para o que consideravam um perigo iminente: a desorganização do trabalho nas lavouras.

É supreendente que, a partir de meados da década de 1880, as principais forças políticas da Província de São Paulo convergissem todas no sentido da imigração européia. Se na década de 1870 podemos encontrar, com certa facilidade, liberais defendendo a importação de trabalhadores asiáticos e conservadores defendendo o aproveitamento do trabalhador nacional, a partir de 1883 estas propostas cedem lugar rapidamente à defesa da imigração européia. Isto não significa, como vimos, que houvesse um consenso acerca desta alternativa, mas as divergências diminuíram significativamente. 


\title{
CONCLUSÃO
}

\author{
Agora vemos em espelho \\ e de maneira confusa, \\ mas, depois, veremos face a face \\ (Epístolas de São Paulo).
}

A historiografia relativa ao processo de reorganização do mercado de trabalho ocorrido no Brasil, durante as últimas décadas da escravidão, conferiu destaque especial às características, impasses, problemas e soluções que surgiram nas Províncias cafeeiras de São Paulo e Rio de Janeiro. Nosso objetivo neste trabalho foi desenvolver uma análise comparada entre uma dessas Províncias e outra raramente citada na bibliografia sobre o tema. Nas poucas vezes em que foram confrontadas, sobressaiu-se o sucesso de uma e o fracasso de outra. São Paulo como modelo opção acertada - a substituição do escravo pelo imigrante europeu, mantendo o crescimento e assumindo a hegemonia política e econômica do país; o Pará como exemplo de ciclo econômico predatório exemplar - ascensão e queda vertiginosas - e de opções equivocadas: o extrativismo e a mão-de-obra livre nacional.

Ao longo dos quatro capítulos, nos quais analisamos opiniões, propostas, expectativas, desilusões, críticas e imagens produzidas por redatores de jornais e presidentes de província, colocamos em discussão aquelas interpretações. Não era nosso intuito apontar equívocos nas análises e promover uma inversão de estereótipos. O que procuramos fazer foi estabelecer parâmetros mais equilibrados de análise. Conforme definiu Marc Bloch, a aplicação do método comparativo em ciências humanas consiste em buscar, para explicar, "semelhanças e diferenças que apresentam duas séries de natureza análoga, tomadas de meios sociais distintos". ${ }^{651}$

Nesse sentido, nosso principal cuidado foi não cometer anacronismos, como o de analisar a história do Pará e de São Paulo nas últimas décadas do século XIX pelo que estas duas regiões vieram a se tornar. Os agentes históricos do período não sabiam que,

${ }^{651}$ BLOCH, Marc. Comparaison. Apud CARDOSO, Ciro Flamarion e BRIGNOLI, Héctor Pérez. Os Métodos da História. Introdução aos problemas, métodos e técnicas da história demográfica, econômia e social. $6^{a}$ ed. Trad. João Maia. Rio de Janeiro: Graal, 2002. p. 409. 
na décadas de 1870, a expansão da borracha e da cafeicultura estava apenas começando e que a primeira, durante seu auge, seria afetada por uma crise sem precedente e insuperável; da mesma forma, presidentes da Província e redatores de jornais de São Paulo sequer sonhavam, até 1886, que os cafeicultores teriam à sua disposição um aumento significativo na oferta de mão-de-obra livre estrangeira antes mesmo da abolição da escravatura ocorrer e que, portanto, a "tempestade" tão temida se dissiparia.

Embora aplicando alguns preceitos básicos do método comparativo, estamos cientes de não ter feito uma análise comparativa propriamente dita. Afinal, trabalhamos em uma perspectiva de tempo sincrônica, de curta duração e de âmbito regional, enquanto os autores que definem suas análises como comparativas fazem praticamente o oposto disso. Mas já foi dito que nenhuma análise pode dispensar completamente a comparação. Nesse sentido, o que fizemos foi escolher duas regiões com certas características que favoreciam a reflexão.

Assim, por exemplo, tanto a economia de São Paulo como a do Pará dependia de produtos exportáveis, mas um de caráter agrícola e outro extrativo. Em razão disso, o grupo econômico e político predominante em São Paulo era agrário, enquanto o do Pará era comercial, embora os grupos que exploravam a riqueza agrária e pastoril desta última ocupassem uma posição de destaque na economia, na sociedade e na política. As distinções e semelhanças não param por aí. Enquanto em São Paulo a mão-de-obra mais utilizada na produção para exportação era a do escravo, no Pará a extração e exportação da borracha eram realizadas principalmente com mão-de-obra livre, principalmente índios e miscigenados, aos quais se juntaram, posteriormente, muitos migrantes fugidos das secas da atual região Nordeste.

À primeira vista, as distinções parecem muito mais significativas do que as semelhanças. Porém, considerando que parte da elite regional do Pará almejava promover o desenvolvimento da Província através do incremento da agricultura, as situações se aproximam um pouco mais. Em razão disso, em ambas as Províncias a questão da ampliação da oferta de mão-de-obra e da criação de mecanismo de controle dos trabalhadores tornaram-se prementes. Sem um povoamento consistente, a agricultura paraense não teria como recrutar os braços que necessitava, devido à concorrência da economia da borracha. Esta, por sua vez, também necessitava de uma 
mão-de-obra numerosa, mas preferencialmente nativa ou que se adaptasse facilmente ao trabalho de coleta na floresta tropical.

Esta situação colocou uma parte da elite paraense no mesmo barco que a elite paulista. O problema estava no fato de que, sobre este barco, uma grande tempestade parecia se formar: a abolição da escravatura e, conseqüentemente, a perda da mão-deobra que desde o período colonial havia sido identificada com a produção agrária. Várias opções se colocaram, então, no horizonte: o trabalhador livre nacional, o índio e os trabalhadores estrangeiros, que poderiam vir da América do Norte, da Ásia ou da Europa.

De 1868 a 1889, uma enorme variedade de leis e providências administrativas foram discutida, votadas e implementadas, na tentativa de encontrar uma solução para o problema colocado, qual seja a criação de uma força de trabalho numerosa, disciplinada e dependente. Em meio à crise, os grupos dominantes de ambas as Províncias se viram obrigados a definir a imagem do trabalhador ideal, uma vez que o trabalho compulsório estava com seus dias contados. Embora não fosse a primeira vez que esta necessidade se colocava, nunca se fizera tão premente, pois dela dependiam para encaminhar a solução.

A rigor, o leque de opções se resumia a dois: o trabalhador conhecido, aquele com o qual se convivia diariamente - o escravo, o índio e o chamado trabalhador livre nacional - e aquele como o qual nunca ou raramente se convivera, mas que se considerava possível contar: o estrangeiro. O que tentamos argumentar nos quatro capítulos, porém, é que os redatores de jornais e os presidentes de Província reduziam, no plano das imagens, estas duas opções a uma só. Em outras palavras, as representações sobre o trabalhador ideal - aquele que traria a solução para todos os males - era, na realidade, uma imagem construída pela projeção de características, em geral invertidas, do trabalhador com o qual se convivia.

Com estamos nos referindo a imagens e metáforas, um recurso à literatura talvez nos ajude a explicar nossas conclusões. A obra A Tempestade é considerada uma crítica de Shakespeare à expansão marítima européia e à colonização do Novo Mundo. Nela, Prometeu - Duque de Milão - perde seu trono devido a uma traição e é lançado em uma ilha, onde planeja sua vingança. A oportunidade surge quando seus desafetos são conduzidos ao local em um barco, que naufraga devido a uma tempestade tramada por ele e Ariel. Este retribuía, assim, o fato de Prometeu o ter liberdade do feitiço de 
Sycorax, uma bruxa nativa, mãe de Caliban, um ser bárbaro e deformado, que fora escravizado por Prometeu.

A trama construída por Shakespeare contrapõe uma figura disforme e selvagem a outra que é etérea e incorpórea, mas que pode se metamorfosear para ajudar seu amo. O que queremos dizer, portanto, é que o trabalhador livre nacional, o escravo e o índio assumiam no imaginário das elites do período uma imagem semelhante à de Caliban, pois eram retratados como sinônimo de indolência e barbárie; Ariel, por seu turno, corresponderia ao trabalhador idealizado, aquele que seria capaz de realizar tudo o que dele se esperava.

Mas, assim como Ariel e Caliban simbolizariam, na verdade, o próprio ser humano, em sua ambivalência, podemos dizer que as imagens produzidas sobre os trabalhadores também compunham um mesmo todo. Como assinalaram Michael Hall e Verena Stolke, o sistema de colonato foi implantado em São Paulo após várias décadas de conflito em que trabalhadores e empregadores experimentaram várias formas de trabalho até que se chegasse a um resultado que satisfazia, em parte, os dois lados. Os ajustes feitos não dependeram, contudo, apenas das decisões de fazendeiros e colonos. Afinal, a ampliação da força de trabalho por meio da inserção do imigrante dependeu, também, de uma série de questões políticas e administrativas. Os representantes dos fazendeiros que optaram pelo trabalhador estrangeiro tiveram de convencer seus pares a canalizar recursos para os projetos imigrantistas. $O$ estabelecimento de núcleos coloniais, abertura de estradas, concessão de passagens e adiantamento de salários, entre outras medidas necessárias ao sucesso da política imigrantista, eram decisões que dependiam da aceitação de um número expressivo de políticos e governantes, para que se materializassem.

Assim, ao longo de várias décadas, redatores de jornais e presidentes de província, entre outros setores, idealizaram a imagem do trabalhador ideal, que viria substituir o escravo, em vias de conquistar a liberdade, e ocupar o lugar que o trabalhador livre nacional parecia rejeitar. Porém, as greves, deserções e questões trabalhistas, as reclamações e exigência feitas às comissões de colonização e publicadas em jornais, as pressões das autoridades diplomáticas, que visitavam colônias para averiguações de queixas, obrigavam os setores interessados em promover a imigração européia a realizarem ajustes na imagem idealizada. 
Nos momentos mais tensos e delicados, fazendeiros como o Visconde de Indaiatuba, um dos pioneiros na introdução de trabalhadores europeus nas lavouras de café, acabaram se desiludindo e se sentindo incapazes de lidar com os imigrantes. Alguns apoiaram propostas governamentais para realizar uma transição mais suave, importante trabalhadores asiáticos, tidos como meio-termo entre o escravo e o trabalhador livre. Outros acabaram voltando a empregar escravos de forma majoritária em suas fazendas. A partir de determinado momento, porém, os fazendeiros e seus representantes compreenderam a necessidade de serem mais pragmáticos. Ao darem preferência às famílias e àqueles imigrantes que já tinham parentes ou amigos estabelecidos no Brasil, bem como ao italiano e não aos povos do Norte da Europa considerados os mais aptos ao trabalho agrícola - os imigrantistas revelavam uma estratégia destinada a evitar ou minimizar problemas de adaptação no futuro. Aos poucos, portanto, as imagens de Ariel e Caliban foram se fundindo e a "tempestade" se dissipou. A abolição da escratura não foi acompanhada da tão temida desorganização do trabalho nas lavouras. A economia cafeeira e os negócios da borracha continuaram prosperando.

No Pará, as expectativas depositadas no imigrante europeu e, posteriormente, no trabalhador cearense também tiveram de ser modificadas, após alguns incidentes. As queixas dos colonos do núcleo Benevides foram duro golpe naqueles que acreditavam que o imigrante europeu transformaria o Pará em um celeiro de alimentos. Em relação aos cearenses, o entusiasmo inicial - sobretudo porque a chegada de grandes levas de retirantes coincidia com o fracasso da experiência européia em Benevides - cedeu lugar a uma dura realidade: ruas repletas de mendigos, cadeias e hospitais superlotados, epidemias e escassez de alimentos etc. Completando o desalento, a partir de meados da década de 1880 ficou claro que o migrante preferia o trabalho no seringal.

Ao contrário do que ocorreu em São Paulo, o fluxo imigratório em direção ao Pará não aumentou. À exceção das iniciativas governamentais, que resultaram na criação de alguns núcleos coloniais, o número de imigrantes europeus que se estabeleceram na Província esteve muito aquém do esperado. Mas, colocarmos as experiências de São Paulo e Pará em termos de sucesso e fracasso é projetar para as últimas décadas da escravidão uma realidade que se cristalizaria algum tempo depois. A leitura dos jornais e relatórios dos presidentes de província revela que até 1889 não se 
considerava resolvida a questão da reorganização do mercado de trabalho, mesmo em São Paulo. Hoje em dia, localizamos o ano de 1886 como sendo o de início da imigração em massa. Naquele momento, os adeptos da imigração européia apenas comemoravam a chegada de levas mais freqüentes e numerosas do que a dos anos anteriores.

Parece claro que algumas resoluções tomadas em São Paulo colaboraram para isso. A decisão de conceder a subvenção apenas para familiares, parentes próximos e amigos dos imigrantes já estabelecidos na Província parece ter sido fundamental naquela oportunidade. Os que aqui aportavam a partir de então, além de terem algum conhecimento do que encontrariam pela frente, podiam contar com uma rede de apoio no duro período de adaptação. Da mesma forma, a nomeação de imigrantes para ocupar cargos em hospedarias e núcleos coloniais, a decisão de ouvir e procurar atender as queixas dos imigrantes também foi importante.

Todavia, não foi nosso intuito nesse trabalho discutir as causas do sucesso ou fracasso das tentativas de colonização e imigração. $\mathrm{O}$ que quisemos foi bem mais modesto. Nosso intuito foi discutir imagens produzidas acerca do imigrante, e não a imigração propriamente dita. Quisemos assinalar que estas imagens nos ajudam a compreender muito mais as relações entre os empregadores e os escravos e os trabalhadores livres existentes no país do que o imigrante, que elas nos permitem compreender que a opção pela imigração européia não se destinava apenas a garantir a sobrevivência da grande propriedade ou a continuidade da produção agrícola, mas principalmente o status quo dos grupos dominantes. Ao idealizarem o imigrante, redatores de jornais e presidente de província se colocavam, portanto, diante de um espelho.

O debate sobre a reorganização do mercado de trabalho nas Províncias do Pará e São Paulo nos ajudou a compreender um pouco mais as relações entre o Governo Imperial e as elites regionais. Procuramos evitar, ao longo dos quatro capítulos desta tese, estabelecer clivagens regionais ou de qualquer outro tipo, pois entendemos que havia uma intensa negociação entre os grupos dirigentes e aqueles envolvidos na exploração da agricultura e do extrativismo. Antes mesmo que o Estado Nacional se constituisse no Brasil, a existência de uma força de trabalho numerosa, disciplinada e depedente já se colocava como uma das principais necessidades das elites econômicas 
regionais. A partir de meados do século XIX, quando as pressões contra o tráfico negreiro e contra a própria escravidão passaram a sinalizar a próximidade da extinção do trabalho compulsório, tal necessidade se tornou premente. Argumentamos, assim, que a adoção de políticas públicas no sentido de buscar alternativas de suprimento de braços e canalizar os braços disponíveis para as principais atividades econômicas se transformou numa espécie de moeda de troca entre o Governo Imperial e as elites regionais.

Isto não significa que concebemos a existência de uma burocracia e de uma elite política nacional com existência autônoma em relação aos grupos que designamos como elites regionais. Estas possuíam representantes no sistema político imperial e, mesmo quando sub-representadas, tinham condições de negociar o atendimento às suas reivindicações. As críticas a um suposto favorecimento de outras regiões em detrimento das suas, às substituições de presidentes de província e ao desconhecimento que muitos destes teriam em relação aos problemas e necessidades locais eram uma das formas que as elites regionais tinham de exigir sua participação na elaboração e condução da política imperial. Não era por acaso que estas e outras críticas - alguns mais radicais chegavam a reivincar maior autonomia para suas províncias - ocorriam em todas as regiões do país. 


\section{FONTES}

- Jornais

- Jornais publicados na Província de São Paulo:

- A Província de São Paulo

- Tribuna Liberal

- Correio Paulistano

- Gazeta de Campinas

- Opinião Liberal

- A Constituição

○ Jornais publicados na Província do Pará:

- A Província do Pará

- Liberal do Pará

- Diário de Notícias

- Diário de Belém

- Anais do Legislativo Provincial

- Anais da Assembléia Legislativa Provincial de São Paulo

- Relatórios de Presidentes de Província

- Província do Pará

Pará. Falla que o excellentissimo senhor visconde de Arary, primeiro vice-presidente desta provincia, dirigio a Assembléa Legislativa Provincial no dia 15 de agosto de 1868, por occasião da abertura da primeira sessão da 16. legislatura da mesma Assembléa. Pará: Typ. do Diario do Gram-Pará, 1868.

Pará. Relatorio com que o excellentissimo senhor vice-presidente e conselheiro de guerra Joaquim Raymundo de Lamare passou a 
administração da Província do Gram-Pará ao excellentissimo senhor visconde de Arary $1^{o}$. vice-presidente em 6 de agosto de 1868. Pará: typographia do Diário do Gram-Pará, 1868.

Pará. Relatorio com que o excellentissimo senhor Visconde de Arary entregou a administração da Provincia do Gram-Pará ao Excellentissimo Senhor $1^{o}$. vice-presidente Cônego Manoel Jozé de Siqueira Mendes em 29 de setembro de 1868. Pará: typographia do Diario do Gram-Pará, 1868.

Pará. Relatório apresentado a Assembléia Legislativa da Província do Gram-Pará pelo $1^{o}$. Vice-Presidente da Província Manoel Jozé de Siqueira Mendes, 18 de outubro de 1868. [s. ed.]

Pará. Relatorio que o excellentissimo senhor coronel Miguel Antonio Pinto Guimarães, segundo vice-presidente da provincia, dirigio á Assembléa Legislativa Provincial no dia 15 de agosto de 1869 por occasião da abertura da segunda sessão da 16.a legislatura da mesma Assembléa. Pará: Typ. do Diario do Gram-Pará, 1869.

Pará. Relatorio com que o excellentissimo senhor presidente da província conselheiro José Bento da Cunha Figueiredo entregou a administração da província do Gram-Pará ao excellentissimo senhor $2^{\circ}$. vice-presidente coronel Miguel Antonio Pinto Guimarães em 16 de maio de 1869. Pará: Typographia do Diario do Gram-Pará, 1869.

Pará. Relatorio com que o excellentissimo coronel Miguel Antonio Pinto Guimarães segundo vice-presidente da provincia do Pará passou a administração da mesma ao excellentissimo senhor primeiro vicepresidente conego Manoel Jose de Siqueira Mendes. Pará: Typographia do Diario do Gram-Pará, 1870.

Pará. Relatorio com que o excellentissimo senhor conego Manoel Jose de Siqueira Mendes primeiro vice-presidente da provincia do Pará passou a administração da mesma ao excellentissmo senhor presidente João Alfredo Corrêa de Oliveira. Pará: Typographia do Diario do Gram-Pará, 1870.

Pará. Relatorio apresentado á Assembléa Legislativa Provincial na primeira sessão da $17^{a}$. legislatura pelo quarto vice-presidente, dr. Abel Graça. Pará: Typ. do Diario do Gram-Pará, 1870.

Pará. Relatorio do presidente da provincia do Pará doutor João Alfredo Corrêa de Oliveira passando a administração da mesma ao $4^{o}$. vicepresidente doutor Abel Graça. Pará: Typographia do Diario do GramPará, 1870. 
Pará. Relatorio apresentado á Assembléa Legislativa Provincial na segunda sessão da 17.a legislatura pelo dr. Abel Graça, presidente da provincia. Pará: Typ. do Diario do Gram-Pará, 1871.

Pará. Relatorio apresentado á Assembléa Legislativa Provincial na primeira sessão da 18.a legislatura em 15 de fevereiro de 1872 pelo presidente da provincia, dr. Abel Graça. Pará: Typ. do Diario do GramPará, 1872.

Pará. Relatorio apresentado pelo Exm. Sr. Barão da Villa da Barra em 5 de novembro de 1872 por occasião de passar a administração da provincia ao $2^{o}$. vice-presidente o Exm. Sr. Barão de Santarem. Pará: typographia do Diario do Gram-Pará, 1872.

Pará. Relatorio com que o excellentissimo senhor doutor Domingos José da Cunha Junior, presidente da provincia, abriu a $2^{a}$. sessão da $18^{a}$. legislatura da Assembléa Legislativa Provincial em 1.o de julho de 1873. Pará: Typ. do Diario do Gram-Pará, 1873.

Pará. Relatorio com que o excellentissimo senhor barão de Santarem, $2^{\circ}$. vice-presidente da provincia passou a administração da mesma ao excellentissimo senhor doutor Domingos José da Cunha Junior em 18 de abril de 1873. Pará: Typ. do Diario do Gram-Pará, 1873.

Pará. Relatorio com que o excellentissimo senhor doutor Domingos José da Cunha Junior passou a administração da provincia do Pará ao $3^{\circ}$. vice-presidente, o excellentissimo senhor doutor Guilherme Francisco Cruz em 31 de dezembro de 1873. Pará: Typ. do Diario do Gram-Pará, 1873.

Pará. Relatorio apresentado a Assembléa Legislativa Provincial na primeira sessão da 19 . legislatura pelo presidente da provincia do Pará, o excellentissimo senhor doutor Pedro Vicente de Azevedo, em 15 de fevereiro de 1874. Pará: Typ. do Diario do Gram-Pará, 1874.

Pará. Relatorio com que o excellentissimo senhor doutor Guilherme Francisco Cruz $3^{\circ}$. vice-presidente passou a administração da provincia do Pará ao excelletissimo senhor doutor Pedro Vicente de Azevedo em 17 de janeiro de 1874. Pará: typographia do Diario do Gram-Pará, 1874.

Pará. Relatorio com que o excellentissimo senhor doutor Francisco Maria Corrêa de Sá e Benevides, presidente da provincia, abriu a $2^{a}$. sessão da 19. a legislatura da Assembléa Legislativa Provincial no dia 15 de fevereiro de 1875. Pará: Typ. do Diario do Gram-Pará, 1875. 
Pará. Relatorio apresentado ao exm. senr. dr. Francisco Maria Corrêa de Sá e Benevides pelo exm. senr. dr. Pedro Vicente de Azevedo, por occasião de passar-lhe a administração da provincia do Pará, no dia 17 de janeiro de 1875. Pará: [Typ. de F.C. Rhossard], 1875.

Pará. Relatorio apresentado pelo exm. sr. dr. Francisco Maria Corrêa de Sá e Benevides, presidente da provincia do Pará, á Assembléa Legislativa Provincial na sua sessão solemne de installação da $20^{a}$. legislatura, no dia 15 de fevereiro de 1876. Pará: [s. ed.] 1876.

Pará. Relatorio com que o exm. sr. presidente da provincia do Pará, dr. Francisco Maria Corrêa de Sá e Benevides, entregou a administração da mesma ao exm. sr. dr. João Capistrano Bandeira de Mello Filho em 18 de julho de 1876. Pará: Typ. do Diario do Gram-Pará, 1876.

Pará. Falla com que o exm. sr. dr. João Capistrano Bandeira de Mello Filho abrio a $2^{a}$. sessão da $20^{a}$. legislatura da Assemblea Legislativa da provincia do Pará em 15 de fevereiro de 1877. Pará: Typ. do Livro do Commercio, 1877.

Pará. Falla com que o exm. senr. dr. José Joaquim do Carmo abrio a 1.a sessão da 21.a legislatura da Assembléa Legislativa da provincia do Pará em 22 de abril de 1878. Pará: Typ. da Provincia do Pará, 1878.

Pará. Relatorio com que ao exm. sr. dr. José da Gama Malcher, $1^{o}$. vicepresidente, passou a administração da provincia do Pará o exm. sr. dr. João Capistrano Bandeira de Mello Filho em 9 de março de 1878. Pará: Typ. Guttemberg, 1878.

Pará. Falla com que o excellentissimo senhor doutor José Coelho da Gama e Abreu, presidente da provincia, abriu a $2^{a}$. sessão da $21^{a}$. legislatura da Assembléa Legislativa da provincia do Gram-Pará, em 16 de junho de 1879. Pará: [s. ed.], 1879.

Pará. Relatorio apresentado pelo excellentissimo senhor doutor José Coelho da Gama e Abreu, presidente da provincia, á Assembléa Legislativa Provincial do Pará, na sua $1^{a}$. sessão da $22^{a}$. legislatura, em 15 de fevereiro de 1880. Pará: [s. ed.], 1880.

Pará. Relatorio apresentado á Assembléa Legislativa Provincial na $2^{a}$. sessão da 22a. legislatura em 15 de fevereiro de 1881 pelo exm. sr. dr. José Coelho da Gama e Abreu. Pará: Typ. do Diario de Noticias de Costa \& Campbell, 1881.

Pará. Relatorio com que o excellentissimo sr dr José da Gama Malcher, $1^{o}$. vice-presidente da provincia passou a administração da mesma ao Exm. Sr. Dr. Manoel Pinto de Souza Dantas Filho em 27 de abril de 1881. Pará: Typ. do Diario de Notícias de J. Campbell, 1882. 
Pará. Relatorio com que o exm. sr. presidente, dr. Manuel Pinto de Souza Dantas Filho, passou a administração da provincia ao exm. sr. $1^{o}$. vicepresidente, dr. José da Gama Malcher. Pará: Typ. do Liberal do Pará, 1882.

Pará. Falla com que o exm.o snr. dr. João José Pedrosa abrio a 1.a sessão da $23^{a}$. legislatura da Assembléa Legislativa da provincia do Pará em 23 de abril de 1882. Pará: Typ. de Francisco da Costa Junior, 1882.

Pará. Relatorio com a Sua Exc. o Sr. Dr. Justino Ferreira Carneiro passou a administração da provincia do Pará no dia 25 de agosto de 1882 ao Exc. Sr. Conselheiro João Rodrigues Chaves, $1^{\circ}$. vicepresidente da mesma Província. Pará: typ Commercio do Pará, 1882.

Pará. Relatorio com que o Exm. Sr. Conselheiro João Rodrigues Chaves, passou a administração da Província no dia 6 de dezembro de 1882 ao Exm. Sr. Dr. Justino Ferreira Carneiro. Pará: Typ do Jornal da Tarde, 1882.

Pará. Relatorio com o Exm. Sr. Conselheiro $1^{o}$. vice-presidente da província João Rodrigues Chaves passou a administração da província ao S. Exc. o Sr. Barão de Maracajú presidente da província. Pará: Typ. do Jornal da Tarde, 1882.

Pará. Falla com que o exm. sr. general barão de Maracajú abriu a $2^{a}$. sessão da $23^{a}$. legislatura da Assembléa Legislativa da provincia do Pará em 15 de fevereiro de 1883. Pará: Typ. do Jornal da Tarde, 1883.

Pará. Falla com que o exm. sr. general visconde de Maracajú presidente da provincia do Pará, pretendia abrir a sessão extraordinaria da respectiva Assembléa no dia 7 de janeiro de 1884. Pará, Diario de Noticias, 1884.

Pará. Relatorio com que o exmo . snr. general visconde de Maracajú passou a administração da provincia ao $2^{\circ}$. vice-presidente, exm.o snr. dr. José de Pará. Araujo Roso Danin, no dia 24 de junho de 1884. Pará: Typ. de Francisco da Costa Junior, 1884.

Pará. Relatorio com o exm. snr. dr. José de Araújo Roso Daini, $2^{o}$. Vicepresidente da provincia passou a administração da mesma ao $\mathrm{Exm}^{\circ} \mathrm{Snr}$. Conselheiro João Silveira de Souza, no dia 4 de agosto de 1884, nomeado presidente por carta imperial de 31 de maio ultimo. Pará: Typ. de Francisco da Costa Junior, 1885.

Pará. Falla com que o exm snr. Conselheiro João Silveira de Sousa, abriu a $1^{o}$. Sessão da 25 . legislatura da Assembléa Legislativa 
Provincial em 15 de outubro de 1884. Pará: Typ. de Francisco da Costa Junior, 1885.

Pará. Falla com que o exm. sr. conselheiro dr. João Silveira de Souza, presidente da provincia do Pará, abrio a $2^{a}$. sessão da 24.a legislatura da Assembléa Provincial em 18 de abril de 1885. Pará: Typ. da Gazeta de Noticias, 1885.

Pará. Relatorio que ao exm. sr. dr. João Lourenço Paes de Souza, $1^{o}$. vice-presidente da provincia do Gram-Pará, apresentou o exm. sr. dr. Carlos Augusto de Carvalho ao passar-lhe a administração em 16 de setembro de 1885. Pará: Typ. de Francisco de Costa Junior, 1885.

Pará. Relatório que o exm. sr. Conselheiro Tristão de Alencar Araripe apresentou ao exm. sr. dr. João Lourenço Paes de Souza, 1'. vicepresidente da provincia ao passar-lhe a administração da mesma em 5 de outubro de 1885. Belém: Typographia do Diario de Noticias, 1886.

Pará. Falla com que o exm. conselheiro Tristão Alencar Araripe, presidente da província do Pará, abriu a sessão extraordinária da Assembléa Legislativa provincial no dia 5 de novembro de 1885. Pará: Typographia do Diário de Noticias, 1886.

Pará. Falla com que o exm. sr. conselheiro Tristão de Alencar Araripe, presidente da provincia do Pará, abriu a $1^{a}$. sessão da 25.a legislatura da Assembléa Provincial no dia 25 de março de 1886. Belem: Typ. do Diario de Noticias, 1886.

Pará. Relatorio com que o exm. sr. conselheiro Tristão Alencar Araripe passou a administração da provincia ao exm. sr. Conselheiro João Antonio de Araújo Freitas Henriques em 15 de abril de 1886. Belém: Typ. do Diário de Noticias, 1887.

Pará. Relatório com que o exm. snr. Conselheiro João Antonio d' Araújo Freitas Henriques passou a administração da provincia do Pará ao exm. snr. desembargador Joaquim da Costa Barradas em 6 de outubro de 1886. Pará: Typ. da Republica, 1891.

Pará. Falla com que o exm. snr. desembargador Joaquim da Costa Barradas abriu a sessão extraordinária da Assembléa Legislativa provincial do Pará em 20 de novembro de 1886. Belém: Typ. do Diário de Noticias, 1887.

Pará. Relatorio com que o exm. sr. desembargador Joaquim da Costa Barradas passou a administração da provincia ao exm. sr. conselheiro coronel Francisco José Cardoso Junior. Pará: Typ. do Diario de Noticias, 1887. 
Pará. Falla com que o exm. sr. conselheiro Francisco José Cardoso Junior, $1^{o}$. vice-presidente da provincia do Pará, abrio a $2^{a}$. sessão da 25.a legislatura da Assembléa Provincial em 20 de outubro de 1887. Pará: Typ. do Diario de Noticias, 1887.

Pará. Relatorio com que o exm. snr. conselheiro Francisco José Cardoso Junior, $1^{o}$. vice-presidente, passou a administração da provincia, no dia 6 de maio de 1888 ao exm. snr. dr. Miguel J. de Almeida Pernambuco, nomeado por carta imperial de 24 de março ultimo. Pará: Typ. do Diario de Noticias, 1888.

Pará. Falla com que o exm. sr. conselheiro Francisco José Cardoso Junior, primeiro vice-presidente da provincia do Pará, abrio a $1^{a}$. sessão da 26a . legislatura da Assembléa Provincial no dia 4 de março de 1888. Pará: Typ. do Diario de Noticias, 1888.

Pará. Falla com que o exm.o snr. dr Miguel José Almeida Pernambuco, presidente da provincia, abrio a $2^{a}$. sessão da $26 . a$ legislatura da Assembléa Legislativa Provincial do Pará em 2 de fevereiro de 1889. Pará: Typ. de A.F. da Costa, 1889.

Pará. Relatorio com que o exm. sr. dr. Miguel Jose d' Almeida Pernambuco, presidente da provincia passou a administração da mesma ao vice-presidente da provincia exm. snr. dr. João Polycarpo dos Santos Campos em 18 de março de 1889. Pará: Typ. de A. Fructuoso da Costa, 1889.

Pará. Relatorio com que o exm. sr. dr. José de Araújo Roso Danin, $1^{o}$. Vice-presidente da provincia do Pará passou a administração da mesma ao exm. sr. dr. Antonio José Ferreira Braga, presidente nomeado por Dec. de 22 de julho de 1889. Pará: Tp. de A. Fructuoso da Costa, 1889.

Pará. Relatorio com que o exm. sr. dr. Antonio José Ferreira Braga, presidente da provincia abrio a sessão extraordinária da $26^{a}$. legislatura da Assembléa Legislativa Provincial do Pará em 18 de setembro de 1889. Pará: Tp. de A. Fructuoso da Costa, 1889.

○ Província de São Paulo

São Paulo. Relatorio apresentado a Assembléa Legislativa Provincial de São Paulo na primeira sessão da decima oitava legislatura no dia 2 de fevereiro de 1868 pelo presidente da mesma provincia, o conselheiro Joaquim Saldanha Marinho. São Paulo: Typ. do Ypiranga, 1868. 
São Paulo. Relatorio com que s. exc. o sr. presidente o conselheiro Joaquim Saldanha Marinho passou a administração da provincia de $S$. Paulo a s. exc. o dr. vice-presidente coronel Joaquim Floreano de Toledo a 24 de abril de 1868. S. Paulo: typographia do Ypiranga, 1868.

São Paulo. Relatorio com que o exm. sr. coronel Joaquim Floriano de Toledo passou a administração da provincia ao exm. sr. Barão do Tietê. S. Paulo: typographia Americana, 1868.

São Paulo. Relatorio com o exm. sr. vice-presidente Barão do Tietê passou a administração da província a s. exc. o sr. dr. José Elias Pacheco Jordão $1^{o}$. vice-presidente. S. Paulo: typographia Americana, 1868.

São Paulo. Relatorio com o exc. sr. $1^{o}$. vice-presidente dr. José Elias Pacheco Jordão passou a administração da provincia a s. exc. o sr. senador Barão de Itauna. S. Paulo: typographia Americana, 1868.

São Paulo. Relatorio com que s. exc. o sr. senador barão de Itauna passou a administração da provincia ao exm. sr. commendador Antonio Joaquim da Rosa, $3^{o}$. vice-presidente. São Paulo: Typ. Americana, 1869.

São Paulo. Relatorio com que o exm. sr. dr. José Elias Pacheco Jordão abrio a Assembléa Legislativa Provincial. São Paulo: Typ. Americana, 1869.

São Paulo. Relatorio com o exc. sr. commendador Antonio Joaquim da Rosa passou a administração da província ao exm. sr. dr. José Elias Pacheco Jordão $1^{o}$. vice-presidente. S. Paulo: typographia Americana, 1869.

São Paulo. Relatorio com que o exc. sr. dr. José Elias Pacheco Jordão passou a adminstração da provincia ao exc. sr. Vicente Pires da Motta $1^{o}$. vice-presidente. S. Paulo: typographia Americana, 1869.

São Paulo. Relatorio com que o exc. sr. Vicente Pires da Motta passou a administração da provincia ao exc. dr. Antonio Candido da Rocha. S. Paulo: typographia Americana, 1869.

São Paulo. Relatorio apresentado á Assembléa Legislativa Provincial de S. Paulo pelo presidente da provincia, o exm. sr. dr. Antonio Candido da Rocha, no dia 2 de fevereiro de 1870. S. Paulo: Typ. Americana, 1870.

São Paulo. Relatorio com que o exc. sr. presidente dr. Antonio Candido da Rocha passou a administração da provincia ap exm. conselheiro Vicente Pires da Motta $1^{o}$. vice-presidente da mesma. S. Paulo: typographia Americana, 1870. 
São Paulo. Relatorio apresentado á Assembléa Legislativa Provincial de S. Paulo pelo presidente da provincia, o exm. sr. dr. Antonio da Costa Pinto Silva, no dia 5 de fevereiro de 1871. S. Paulo: Typ. Americana, 1871.

São Paulo. Relatorio com que o exm. sr. dr. Antonio da Costa Pinto Silva presidente da província passou a administração da mesma ao exm. sr. conselheiro Vicente Pires da Motta $1^{o}$. vice-presidente. S. Paulo: Tpographia Americana, 1871.

São Paulo. Relatorio com que o exm. sr. conselheiro Vicente Pires da Motta $1^{o}$. vice-presidente passou a administração da provincia ao exm. sr. Barão do Tietê $5^{o}$. vice-presidente. S. Paulo: Tpographia Americana, 1871.

São Paulo. Relatorio com que o exm. sr. Barão do Tietê $5^{o}$. vicepresidente passou a administração da provincia ao exm. sr. dr. José Fernandes da Costa Pereira. S. Paulo: Typographia Americana, 1871.

São Paulo. Relatorio apresentado á Assembléa Legislativa Provincial de São Paulo pelo presidente da provincia, o exm. sr. dr. José Fernandes da Costa Pereira Junior, em 2 de fevereiro de 1872. São Paulo: Typ. Americana, [1872].

São Paulo. Relatorio com que o exm. sr. dr. José Fernandes da Costa Pereira Junior passou a administração da provincia ao exm. sr. conselheiro Francisco Xavier Pinto Lima. S. Paulo: Typographia Americana, 1872.

São Paulo. Relatorio com que o exm. sr. dr. conselheiro Francisco Xavier Pinto Lima passou a administração da provincia ao exm. sr. dr. João Theodoro Xavier presidente da mesma. S. Paulo: Typographia Americana, 1872.

São Paulo. Relatorio apresentado á Assembléa Legislativa Provincial pelo exm. sr. dr. João Theodoro Xavier, presidente da provincia, no dia 5 de fevereiro de 1873. S. Paulo: Typ. Americana, 1873.

São Paulo. Relatorio apresentado á Assembléa Legislativa Provincial de S. Paulo pelo presidente da provincia, o exm. sr. dr. João Theodoro Xavier em 5 de fevereiro de 1874. S. Paulo: Typ. Americana, 1874.

São Paulo. Relatorio apresentado á Assembléa Legislativa Provincial de S. Paulo pelo exm. sr. dr. João Theodoro Xavier, presidente da provincia, no dia 14 de fevereiro de 1875. S. Paulo: Typ. do Diario, 1875. 
São Paulo. Relatorio com que o exm. monsenhor dr. Joaquim Manoel Gonçalves de Andrade $5^{\circ}$. Vice-presidente passou a administração da provincia de S. Paulo ao exm. sr. dr. Sebastião José Pereira presidente da mesma no dia 8 de junho de 1875. S. Paulo: Typographia do Diário, 1875 .

São Paulo. Relatorio apresentado pelo exm. sr. Sebastião José Pereira presidente da provincia á Assembléa Legislativa Provincial no dia 27 de junho de 1875 por occasião da abertura de sua reunião extraordinária. S. Paulo: Typographia do Diario, 1875.

São Paulo. Relatorio apresentado á Assembléa Legislativa Provincial de S. Paulo pelo presidente da provincia, exm. sr. dr. Sebastião José Pereira, em 2 de fevereiro de 1876. S. Paulo: Typ. do Diario, 1876.

São Paulo. Relatorio apresentado á Assembléa Legislativa Provincial de S. Paulo pelo presidente da provincia, o exm. sr. dr. Sebastião José Pereira em fevereiro de 1877. S. Paulo: Typ. do Diario, 1877.

São Paulo. Relatorio com que o exm. sr. dr. Sebastião José Pereira passou a administração da provincia ao 5 o vice-presidente, monsenhor Joaquim Manoel Gonçalves de Andrade. S. Paulo: Typ. do Diario, 1878.

São Paulo. Relatorios do exm. monsenhor Joaquim Manoel Gonçalves de Andrade, $5^{\circ}$. vice-presidente da provincia e do exm. sr. commendador A. de Aguiar Barros, $6^{o}$. vice presidente, apresentado á Assembléa Legislativa Provincial, transmitindo a administração ao presidente da mesma, exm. sr. dr. João Baptista Pereira. S. Paulo: Typ. do Diario, 1878.

São Paulo. Relatorio com que o exm. sr. Sebastião José Pereira passou a administração da província ao $5^{\circ}$. vice-presidente mosenhor Joaquim Manoel Gonçalves de Andrade. S. Paulo: Typ. do Diario, 1878.

São Paulo. Relatorio apresentado á Assembléa Legislativa Provincial de São Paulo pelo $2^{o}$. vice-presidente da provincia, o exm. sr. Barão de Tres Rios, no dia 2 de fevereiro de 1879. São Paulo: Typ. da Tribuna Liberal, 1879.

São Paulo. Relatorio apresentado á Assembléa Legislativa Provincial de S. Paulo pelo presidente da provincia, Laurindo Abelardo de Brito, no dia 5 de fevereiro de 1880. Santos: Typ. a vapor do Diario de Santos, 1880 .

São Paulo. Relatorio apresentado á Assembléa Legislativa Provincial de S. Paulo pelo presidente da provincia, Laurindo Abelardo de Brito, no dia 13 de janeiro de 1881. Santos: Typ. a vapor do Diario de Santos, 1881. 
São Paulo. Exposição com que o exm. sr. dr. Laurindo Abelardo de Brito passou a administração da provincia de S. Paulo ao exm. sr. Conde de Tres-Rios $1^{\text {o }}$. vice-presidente no 4 de março de 1881. Santos: Typographia a vapor do Diario de Santos, 1881.

São Paulo. Relatorio dirigido á Assembléa Legislativa Provincial de S. Paulo pelo $1^{o}$. vice-presidente da provincia, Conde de Tres-Rios, $e$ apresentado no acto da installação da mesma Assembléa pelo $4^{o}$. vicepresidente, dr. Manoel Marcondes de Moura e Costa. Santos: Typ. a vapor do Diario de Santos, 1882.

São Paulo. Relatorio com que passou a administração da província de $S$. Paulo ao exm. presidente conselheiro Francisco de Carvalho Soares Brandão ao vice-presidente Manoel Marcondes de Moura e Costa. S. Paulo: Typographia Jorge Seckler, 1882.

São Paulo. Falla dirigida á Assembléa Legislativa Provincial de S. Paulo na abertura da $2^{a}$. sessão da $24^{a}$. legislatura em 10 de janeiro de 1883 pelo presidente, conselheiro Francisco de Carvalho Soares Brandão. S. Paulo: Typ. do Ypiranga, 1883.

São Paulo. Relatorio com que passou a administração da provincia de $S$. Paulo ao exm. presidente Barão de Guajará o vice-presidente Visconde de Itú. S. Paulo: Typographia do Commercio, 1883.

São Paulo. Falla dirigida á Assembléa Legislativa Provincial de S. Paulo na abertura da 1.a sessão da 25. a legislatura em 16 de janeiro de 1884 pelo presidente, Barão de Guajará. S. Paulo: Typ. da Gazeta Liberal, 1884.

São Paulo. Relatorio com que o exm. sr. dr. Luiz Carlos d'Assumpção vice-presidente da provincia de São Paulo passou a administração ao presidente exm. sr. dr. José Luiz de Almeida Couto. S. Paulo: Typographia Gazeta Liberal, 1884.

São Paulo. Falla dirigida á Assembléa Legislativa Provincial de S. Paulo na abertura da $2^{a}$. sessão da $26^{a}$. legislatura em 10 de janeiro de 1885 pelo presidente, dr. José Luiz de Almeida Couto. São Paulo: Typ. da Gazeta Liberal, 1885.

São Paulo. Relatorio com que o exm. sr. dr. José Luiz de Almeida Couto presidente da província de São Paulo passou a administração ao $1^{\circ}$. vice-presidente o sr. dr. Francisco Antonio de Souza Queiroz Filho. S. Paulo: Typ. do Correio Paulistano, 1886.

São Paulo. Relatorio com que o sr. dr. Francisco Antonio de Souza Queiroz Filho vice-presicente da provincia de S. Paulo passou a 
administração ao vice-presidente exm. sr. dr. Elias Antonio Pacheco e Chaves. S. Paulo: Typ. Correio Paulistano, [1886].

São Paulo. Relatorio com que passou a administração da província de São Paulo ao exm. presidente conselheiro João Alfredo Corrêa de Oliveira o vice-presidente exm. sr. dr. Elias Antonio Pacheco e Chaves. S. Paulo: Typographia Correio Paulistano, [1886].

São Paulo. Relatorio apresentado á Assembléa Legislativa Provincial de São Paulo pelo presidente da provincia, João Alfredo Corrêa de Oliveira, no dia 15 de fevereiro de 1886. São Paulo: Typ. a Vapor de Jorge Seckler \& C, 1886.

São Paulo. Relatorio com que o conselheiro João Alfredo Corrêa de Oliveira passou a administração da provincia de São Paulo ao vicepresidente Barão do Parnahyba no dia 26 de abril de 1886. S. Paulo: Typographia a vapor de Jorge Seckler, 1886.

São Paulo. Relatorio apresentado á Assembléa Legislativa Provincial de São Paulo pelo presidente da provincia, Barão do Parnahyba, no dia 17 de janeiro de 1887. São Paulo: Typ. a Vapor de Jorge Seckler \& Comp., 1887.

São Paulo. Exposição com o exm. sr. Visconde do Parnahyba passou a administração da provincia de São Paulo ao exm. sr. Francisco de Paula Rodrigues Alves presidente desta provincia no dia 19 de novembro de 1887. S. Paulo: Typographia a vapor de Jorge Seckler \& Comp., 1888.

São Paulo. Relatorio apresentado á Assembléa Legislativa Provincial de São Paulo pelo presidente da provincia, exm. snr. dr. Francisco de Paula Rodrigues Alves, no dia 10 de janeiro de 1888. São Paulo: Typ. a Vapor de Jorge Seckler \& Comp., 1888.

São Paulo. Relatorio com que o exm. sr. dr. Francisco de Paula Rodrigues Alves passou a administração da província de São Paulo ao exm. sr. dr. Francisco Antonio Dutra Rodrigues $1^{o}$. vice-presidente no dia 27 de abril de 1888. S. Paulo: Typographia vapor Jorge Seckler, 1888 .

São Paulo. Exposição com que o exm. sr. dr. Pedro Vicente de Azevedo passou a administração da província de S. Paulo ao exm. sr. $d r$. Francisco Antonio Dutra Rodrigues 1 ${ }^{o}$. Vice-presidente no dia 23 de junho de 1888. S. Paulo: Typographia a vapor Barcel, Pauperio \& Comp., 1888.

São Paulo. Relatorio apresentado á Assembléa Legislativa Provincial de São Paulo pelo presidente da provincia, dr. Pedro Vicente de Azevedo, 
no dia 11 de janeiro de 1889. São Paulo: Typ. a Vapor de Jorge Seckler \& Comp., 1889.

São Paulo. Exposição com que o exm. sr. dr. Pedro Vicente de Azevedo passou a administração da provincia de São Paulo ao exm. sr. dr. Barão de Jaguará no dia 11 de abril de 1889. S. Paulo: Typographia a vapor Jorge Seckler \& Comp., 1889.

São Paulo. Falla com que o exm. sr. dr. Barão de Jaguará abrio a sessão extraordinaria da Assembléa Legislativa Provincial de São Paulo no dia 20 de maio de 1889. S. Paulo: Typographia a vapor de Jorge Seckler \& Comp., 1889.

São Paulo. Exposição com que o exm. sr. dr. Barão de Jaguará passou a administração da provincia de São Paulo ao exm. sr. general dr. José Vieira Couto de Magalhães no dia 10 de junho de 1889. S. Paulo: Typographia a vapor Jorge Seckler, 1889. 


\section{BIBLIOGRAFIA CITADA}

ABREU, Martha. O Império do Divino. Festas Religiosas e Cultura Popular no Rio de Janeiro, 1830-1900. Rio de Janeiro: Nova Fronteira; São Paulo: Fapesp, 1999.

ACEVEDO MARIN, Rosa Elisabeth. Alianças matrimoniais na alta sociedade paraense no século XIX. Op. cit.

ACEVEDO MARIN, Rosa Elizabeth. "O Pará e o movimento abolicionista". Acervo, Rio de Janeiro, 3 (1): 21-36, jan./jun. 1988.

ACEVEDO, Rosa; CASTRO, Edna. Negros do Trombetas. Guardiães de matas e rios. $2^{a}$ ed. Belém: CEJUP, 1998.

ALENCASTRO, Luís Felipe. O Trato dos Viventes. Formação do Brasil no Atlântico Sul. $2^{a}$ reimp. São Paulo: Companhia das Letras, 2000.

ALGRANTI, Leila Mezan. O Feitor Ausente: estudos sobre a escravidão urbana. Rio de Janeiro - 1808-1821. Petrópolis: Vozes, 1988.

ALVIM, Zuleika Maria Forcione. O Brasil Italiano (1880-1920). In: FAUSTO, Boris (org.). Fazer a América. A imigração em massa para a América Latina. São Paulo: Edusp, 1999.

ANDERSON, Benedict. Nação e Consciência Nacional. Trad. de Lólio Lourenço de Oliveira. São Paulo: Ática, 1989.

AZEVEDO, Célia Maria Marinho de. Onda Negra, Medo Branco. O negro no imaginário das elites - Século XIX. Rio de Janeiro, Paz e Terra, 1987.

BAKHTIN, Mikhail. Questões de Literatura e de Estética. A teoria do romance. Trad. De Aurora Fornoni Bernadini e outros. 4. ed., São Paulo: Hucitec, 1998.

BARÃO DE GUAJARÁ. Catechese de índios no Pará. In: Annaes da Bibliotheca e Archivo Publico do Pará. Belém: Imprensa Oficial, 1902. Tomo II.

BARÃO DE JAVARI (org.). Organizações e Programas Ministeriais. Regime parlamentar do Império. $3^{\text {a }}$ ed. Brasília: Ministério da Educação e Cultura, 1979.

BARÃO DE MARAJÓ. As regiões amazônicas. Estudos chorographicos dos Estados do Gram Pará e Amazonas. 2ª ed., Belém: Secult, 1992, p. 369.

BARATA, Manoel. Jornais, revistas e outras publicações periódicas (1822 a 1908). In: Formação Histórica do Pará. Belém: Universidade Federal do Pará, 1973. p. 243-254.

BARATA, Manuel. A antiga produção e exportação do Pará. Estudo históricoeconômico. In: Formação Histórica do Pará. Obras reunidas. Belém: Universidade Federal do Pará, 1973.

BARROS, Diana Luz Pessoa de. Dialogismo, Polifonia e Enunciação. In: BARROS, Diana Luz Pessoa de; FIORIN, José Luiz (org.). Dialogismo, Polifonia, Intertextualidade. São Paulo: Edusp, 2003.

BASTOS, Aureliano Cândido Tavares. Os Males do Presente e as Esperanças do Futuro (Estudos Brasileiros). $2^{\mathrm{a}}$ ed. São Paulo: Ed. Nacional; Brasília: Instituto Nacional do Livro, 1976. 
BATISTA, Luciana Marinho. Muito além dos seringais: elites, fortunas e hierarquias no Grão-Pará, c. 1850 - c. 1870. Dissertação (Mestrado em História). Departamento de História, Universidade Federal do Rio de Janeiro, Rio de Janeiro, 2004.

BECKER, Bertha K. Amazônia. 3ª ed., São Paulo: Ática, 1994.

BEIGUELMAN, Paula. A Formação do Povo no Complexo Cafeeiro. Aspectos

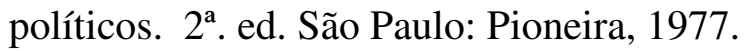

BEZERRA NETO, José Maia. Escravidão Negra no Grão-Pará. Séculos XVIII e XIX. Belém: Paka-Tatu, 2001.

BRASILIENSE, Américo. Os Programas dos partidos e o Segundo Império. Rio de Janeiro, Fund. Casa de Rui Barbosa/ Brasília, Senado Federal, 1979.

CARDOSO, Ciro Flamarion e BRIGNOLI, Héctor Pérez. Os Métodos da História. Introdução aos problemas, métodos e técnicas da história demográfica, econômia e social. $6^{a}$ ed. Trad. João Maia. Rio de Janeiro: Graal, 2002.

CARDOSO, Ciro Flamarion S. (org.). Escravidão e abolição no Brasil. Novas perspectivas. Rio de Janeiro: Jorge Zahar, 1988.

CARDOSO, Ciro Flamarion S. Agricultura, Escravidão e Capitalismo. Petrópolis: Vozes, 1979.

CARDOSO, Fernando Henrique. Condições sociais da industrialização de São Paulo. Revista Brasiliense, São Paulo, 28: 31-46, mar./abr. 1960.

CARNEIRO, José Fernando. Fazendeiros na História do Brasil. Província de São Pedro, Porto Alegre, 11 (21):32-52, dez. 1957.

CARNEIRO, Maria Luiz Tucci. Preconceito Racial em Portugal e Brasil Colônia. Os cristãos-novos e o mito da pureza de sangue. $3^{\text {a }}$ ed. São Paulo: Perspectiva, 2005.

CARVALHO, José Murilo de. Teatro de Sombras: A política imperial. São Paulo: Vértice; Rio de Janeiro: IUPERJ, 1988.

CASTRO, Hebe Maria Mattos de. Das Cores do Silêncio. Os significados da liberdade no sudeste escravista - Brasil séc. XIX. Rio de Janeiro: Arquivo Nacional, 1995.

CHALHOUB, Sidney. Visões da Liberdade. Uma história das últimas décadas da escravidão na corte. São Paulo: Companhia das Letras, 1990.

CHARTIER, Roger. A Aventura do Livro do Leitor ao Navegador. Conversações com Jean Lebrun. Trad. Reginaldo Carmello Corrêa de Moraes. São Paulo: Unesp, 1999.

CHARTIER, Roger. A História Cultural: entre práticas e representações. Rio de Janeiro: Bertrand Brasil, 1990.

COELHO, Geraldo Mártires. Anarquistas, Demagogos \& Dissidentes. A imprensa liberal no Pará de 1822. Belém: Cejup, 1993.

CONRAD, Robert Tumbeiros. O tráfico de escravos para o Brasil. Trad. Elvira Serapicos. São Paulo: Brasiliense, 1985.

CONRAD, Robert. Os últimos anos da escravatura no Brasil. 1850-1888. Trad. Fernando de Castro Ferro. $2^{\mathrm{a}}$. ed., Rio de Janeiro: Civilização Brasileira, 1978.

COSTA, Emília Viotti da. Da Senzala à Colônia. $3^{\text {a }}$ ed. São Paulo: Brasiliense, 1989.

CRUZ, Ernesto. Colonização do Pará. Belém: Instituto Nacional de Pesquisas da Amazônia, 1958. 
CRUZ, Ernesto. História do Pará. Belém: Editora da UFPA, s.d. 2 Vols.

CUNHA, Manuela Carneiro da (org.). Legislação indigenista no século XIX. São Paulo: Edusp; Comissão Pró-Índio de São Paulo, 1992.

DEAN, Warren. Rio Claro: um sistema brasileiro de grande lavoura. 1820-1920. Rio de Janeiro: Paz e Terra, 1977.

DEL PRIORE, Mary. Festas e Utopias no Brasil Colonial. São Paulo: Brasiliense, 1994.

DEL PRIORE, Mary; GOMES, Flávio (org.). Os Senhores dos Rios. Amazônia, Margens e Histórias. Rio de Janeiro: Elsevier. 2003.

DIAS, Maria Odila Leite da Silva. Quotidiano e Poder em São Paulo no Século XIX: Ana Gertrudes de Jesus. São Paulo: Brasiliense, 1984.

DIAS, Maria Odila Silva. A interiorização da Metrópole (1808-1853). In: MOTA, Carlos Guilherme (org.). 1822: Dimensões. 2a . ed; São Paulo: Perspectiva, 1986.

DOHLNIKOFF, Miriam. As elites regionais e a construção do Estado Nacional. In: JANCSÓ, István (org.). Brasil: Formação do Estado e da Nação. São Paulo: HUCITEC/FAPESP; Ijuí: Ed. Unijuí, 2003.

DOHLNIKOFF, Miriam. O Pacto Imperial. Origens do federalismo no Brasil. São Paulo: Globo, 2005.

DORATIOTO, Franciso. Maldita Guerra. Nova história da Guerra do Paraguai. 2a reimpressão. São Paulo: Companhia das Letras, 2002.

EISENBERG, Peter. A mentalidade dos fazendeiros no Congresso Agrícola de 1878. In: LAPA, José Roberto do Amaral (org.). Modos de Produção e Realidade Brasileira. Petrópolis: Vozes, 1980.

EISENBERG, Peter. O Homem Esquecido: o trabalhador livre nacional no século XIX. Sugestões para uma pesquisa. In: Homens Esquecidos. Escravos e Trabalhadores Livres no Brasil. Séculos XVIII e XIX. Campinas (SP): Editora da UNICAMP, 1989.

EL-KAREH, Almir Chaiban. A Companhia de Comércio e Navegação do Amazonas e a Defesa da Amazônia Brasileira: o imaginado grande banquete comercial. V Congresso Brasileiro de História e $6^{a}$ Conferência Internacional de História de Empresas. ABPHE. Caxambú, MG, 7 a 10 de setembro 2003. [Citado 15 novembro 2005]. Disponível na World Wide Web: <www.abphe.org.br/congresso2003/Textos/Abphe_2003_74.pdf>.

EVANGELISTA, Chiara. Os Braços da Lavoura. Imigrantes e "caipiras" na formação do mercado de trabalho paulista (1850-1930). Trad. Thei de Almeida V. Bertorello. São Paulo: Hucitec, 1991.

FERREIRA, Manoel Rodrigues. A Ferrovia do Diabo. História de uma estrada de ferro na Amazônia. São Paulo: Melhoramentos, 1981.

FICO, Carlos; POLITO, Ronald. A História no Brasil (1980-1989). Elementos para uma avaliação historiográfica. Ouro Preto: UFOP, 1982. 2 vols..

FRAGOSO, João Luís Ribeiro. Homens de Grossa Aventura. Acumulação e hierarquia na praça mercantil do Rio de Janeiro (1790-1830). $2^{\text {a }}$ ed. Rio de Janeiro: Civilização Brasileira, 1998. 
FRAGOSO, João; FLORENTINO, Manolo. O Arcaísmo como Projeto. Mercado atlântico, sociedade agrária e elite mercantil em uma economia colonial tardia. Rio de Janeiro, c. 1790 - c. 1840. $4^{\text {a }}$ ed., Rio de Janeiro: Civilização Brasileira. 2001.

FRANCO, Maria Silvia de Carvalho. Homens Livres na Ordem Escravocrata. $3^{\mathrm{a}}$ ed., São Paulo: Kairós, 1983.

FREITAS, Marcos Cezar (org.). Historiografia Brasileira em Perspectiva. São Paulo: Contexto, 1998.

GENOVESE, Eugente. A Terra Prometida. O mundo que os escravos criaram. Trad. Maria Inês Rolim e Donaldson M. Garschagen. Rio de Janeiro: Paz e Terra, 1988.

GOLDMAN, Frank. Aspectos das migrações norte-americanas após a Guerra Civil. In: HOLANDA, Sérgio Buarque de (dir.). História Geral da Civilização Brasileira. $2^{\circ}$. ed. São Paulo: Difel, 1969.

GOMES, Flávio dos Santos. Fronteiras e Mocambos: o protesto negro na Guiana Brasileira. In: GOMES, Flávio dos Santos (org.). Nas Terras do Cabo Norte. Fronteiras, Colonização e Escravidão na Guiana Brasileira - séculos XVIII e XIX. Belém: Editora Universitária/UFPA, 1999.

GOMES, Flávio dos Santos. Histórias de Quilombolas. Mocambos e comunidades de senzalas no Rio de Janeiro - século XIX. Rio de Janeiro: Arquivo Nacional, 1995.

GOMES, Flávio dos Santos. Quilombos, Histórias e as Invenções da Liberdade e do Cativeiro. Cadernos do Centro de Filosofia e Ciências Humanas, Belém, 12 (12): 99-140, jan./dez. 1993.

GOMES, Plínio Freire. Um Herege Vai ao Paraíso. Cosmologia de um ex-colono condenado pela Inquisição (1680-1744). São Paulo: Companhia das Letras, 1997.

GORENDER, Jacob. O Escravismo Colonial. $3^{\mathrm{a}}$. ed., São Paulo, Ática, 1980.

GRAHAM, Richard. Clientelismo e Política no Brasil do Século XIX. Trad. Celina Brandt. Rio de Janeiro: Editora UFRJ, 1997.

HALL, Michael M. The origins of mass immigration in Brazil. 1871-1914. Tese de Ph. D., Columbia University, 1969.

HARDMAN, Francisco Foot. Trem Fantasma. A modernidade na selava. $1^{\mathrm{a}}$. reimp. São Paulo: Companhia das Letras, 1988.

HOLANDA, Sérgio Buarque de. Do Império à República. In: HOLANDA, Sérgio Buarque de (dir.). História Geral da Civilização Brasileira. $3^{\text {a }}$. ed. São Paulo: Difel, 1983. Tomo II, vol. 5.

HOLANDA, Sérgio Buarque de. Prefácio do Tradutor. In: DAVATZ, Thomas. Memórias de um colono no Brasil (1850). Belo Horizonte: Itatiaia; São Paulo: Ed. da Universidade de São Paulo, 1980.

HOLLOWAY, Thomas H. Imigrantes para o Café. Café e sociedade em São Paulo, 1886-1934. Tad. Eglê Malheiros. Rio de Janeiro: Paz e Terra, 1984.

IANNI, Octavio. Colonização e Contra-Reforma Agrária na Amazônia. Petrópolis: Vozes, 1979.

IGLÉSIAS, Francisco. Política Econômica do Governo Provincial Mineiro (18351889). Rio de Janeiro: Ministério da Educação e Cultura, 1958. 
JANCSÓ, István. Este livro. In: JANCSÓ, István (org.). Brasil: Formação do Estado e da Nação. Op. cit. p. 15-28.

KARASCH, Mary. Catequese e cativeiro. Política indigenista em Goiás: 1780-1889. Trad. Beatriz Perrone-Moyses. In: CUNHA, Manuela Carneiro da (org.). História dos Índios no Brasil. 2a . ed. São Paulo: Companhia das Letras; Fapesp; Secretaria Municipal de Cultura, 1992.

KLEIN, Herbert S. A Escravidão Africana. América Latina e Caribe. Trad. José Eduardo de Mendonça. São Paulo: Brasiliense, 1987.

LAPA, José Roberto do Amaral. A Bahia e a Carreira da Índia. São Paulo: Companhia Editora Nacional, 1968.

LAPA, José Roberto do Amaral. História e Historiografia. Brasil pós-64. Rio de Janeiro: Paz e Terra, 1985.

LEITE, Beatriz Westin de Cerqueira. O Senado nos Anos Finais do Império. 18701889. Brasília: Senado Federal/Editora da UNB, 1978.

LENHARO, Alcir. As tropas da Moderação. São Paulo: Símbolo, 1979.

LESSER, Jeffrey. A Negociação da Identidade Nacional. Imigrantes, minorias e a luta pela etnicidade no Brasil. Trad. Patrícia de Queiroz C. Zimbres. São Paulo: Editora da UNESP, 2001.

LINHARES, Maria Yedda. História do abastecimento; uma problemática em questão (1530-1918). Brasília: Binagri, 1979.

LINHARES, Maria Yedda; SILVA, Francisco Carlos Teixeira da. História da Agricultura Brasileira. Combates e Controvérsias. São Paulo: Brasiliense, 1981

MACHADO, Maria Helena. O Plano e o Pânico. Os movimentos sociais na década da abolição. Rio de Janeiro: UFRJ; São Paulo: Edusp, 1994.

MARTINS, José de Souza. A Imigração e a Crise do Brasil Agrário. São Paulo: Pioneira, 1973.

MARTINS, José de Souza. O Cativeiro da Terra. $4^{\text {a }}$ ed. São Paulo: Hucitec, 1990.

MARTINS, Karla Denise. A Civilização Católica: D. Macedo Costa e o desenvolvimento da Amazônia na segunda metade do século XIX. Revista de História Regional. Ponta Grossa (PR), 7 (1): 73-103, 2002.

MARTINS, Karla Denise. Cristóforo e a Romanização do Inferno Verde: as propostas de D. Macedo Costa para a Civilização da Amazônia (1860-1890). Tese (Doutorado em História), Departamento de História, UNICAMP, 2005.

MATTOS, Ilmar Rohloff de. O Tempo Saquarema. A formação do Estado Imperial. São Paulo: Hucitec, 1990.

MATTOSO, Katia Queirós. Ser Escravo no Brasil. São Paulo: Brasiliense, 1982.

MELLO, Evaldo Cabral de. "O Norte, o Sul e a proibição do tráfico interprovincial de escravos". In: O Norte Agrário e o Império. 1871-1889. 2a . ed., Rio de Janeiro: Topbooks, s.d.

MINTZ, Sidney. Caribbean Transformations. Chicago: Aldine Publishing Company, 1974.

MINTZ, Sidney; PRICE, Richard. An Anthropological Approach to the AfroAmerican Past: a Caribbean Perspective. ISHI Occacional Papers in Social Change, $\mathrm{n}^{\circ}$. 2, Philadelphia Institute for the Study of Human Issues, 1976. 
MOREIRA NETO, Carlos de Araújo. Índios da Amazônia. De maioria a minoria (1750-1850). Petrópolis (RJ): Vozes, 1988.

MOURA, Denise Aparecida Soares de. "Andantes de Novos Rumos: a vinda de migrantes cearenses para fazendas de café paulistas em 1878. Revista Brasileira de História, São Paulo, 17 (34): 119-132, 1997.

MUNIZ, Palma. Estado do Grão-Pará. Immigração e Colonização. História e Estatística. 1616-1916. Belém: Imprensa Official do Estado do Pará, 1916.

NOVAIS, Fernando A. Portugal e Brasil na Crise do Antigo Sistema Colonial (17771808). 6 ${ }^{\text {a }}$ ed. São Paulo: Hucitec, 1995.

OBERACKER JUNIOR, Carlos H. A colonização baseada no regime da pequena propriedade agrícola. In: HOLANDA, Sérgio Buarque de (dir.). História Geral da Civilização Brasileira. $2^{\mathrm{a}}$ ed. São Paulo: Difel, 1969.

PENTEADO, António Rocha. Problemas de Colonização e de Uso da Terra na Região Bragantina do Estado do Pará. Lisboa: Junta de Investigações do Ultramar, 1968.

PINHEIRO, Luís Balkar Sá Peixoto. Visões da Cabanagem. Uma revolta popular e suas representações na historiografia. Manaus: Editora Valer, 2001.

PRADO JUNIOR, Caio. Formação do Brasil Contemporâneo. Colônia. $21^{\text {a }}$ ed. São Paulo: Brasiliense, 1989.

QUEIROZ, Jonas Marçal de. Da Senzala à República. Tensões sociais e disputas partidárias em São Paulo (1869-1889). Dissertação (Mestrado em História), Departamento de História, UNICAMP, Campinas, 1995.

QUEIROZ, Polycarpo de. Transformação do Trabalho. Campinas: Castro Mendes, 1888.

RAIOL, Domingos Antônio. Motins Políticos: ou história dos principais acontecimentos políticos da Província do Pará desde o ano de 1821 até 1835. Belém: Universidade Federal do Pará, 1970. 3 vols.

RANGEL, Alberto. Inferno Verde (scenas e scenarios do Amazonas). $2^{\mathrm{a}}$ ed. Famalicão: Typographya Minerva, 1914.

REIS, Arthur Cezar Ferreira. Limites e Demarcações na Amazônia Brasileira. Edição facsimilar, Belém: Secult, 1993, 2 vols.

REIS, Arthur Cezar Ferreira. O Seringal e o Seringueiro. Rio de Janeiro: Ministério da Agricultura, 1953.

REIS, João José e GOMES, Flávio dos Santos (org.). Liberdade Por Um Fio. História dos quilombos no Brasil. São Paulo: Companhia das Letras, 1996.

REIS, João José. Rebelião Escrava no Brasil. A história do levante dos malês (1835). São Paulo: Brasiliense, 1986.

RIBEIRO, Gladys Sabina. A Liberdade em Construção. Identidade nacional e conflitos antilusitanos no Primeiro Reinado. Rio de Janeiro: Relume Dumará, 2002.

SALLES, Vicente. O Negro no Pará - Sob o Regime da Escravidão. Rio de Janeiro: Fundação Getúlio Vargas, 1971.

SAMPAIO, Patrícia Maria Melo. Os Fios de Ariadne. Tipologia de fortunas e hierarquias sociais em Manaus: 1840-1880. Manaus: Editora da Universidade do Amazonas, 1997. 
SANTOS, Ana Maria dos; MENDONÇA, Sonia Regina de. "Representações sobre o trabalho livre na crise do escravismo fluminense (1870-1903)". Revista Brasileira de História, São Paulo, v. 6, n. 11, set. 1985/fev. 1986.

SANTOS, Roberto. História Econômica da Amazônia: 1800-1920. São Paulo: T. A. Queiroz, 1980.

SCHWARTZ, Stuart. Segredos Internos. Engenhos e escravos na sociedade colonial. São Paulo: Companhia das Letras, 1988.

SCWARTZ, Roberto. Ao Vencedor as Batatas. Forma literária e processo social nos inícios do romance brasileiro. 2a . ed. São Paulo: Duas Cidades, 1981. p.13-28.

SLENES, Robert W. Grandeza ou Decadência? O mercado de escravos e a economia cafeeira da Província do Rio de Janeiro, 1850-1888. In: COSTA, Iraci del Nero da (org.): Brasil: História Econômica e Demográfica. São Paulo: Instituto de Pesquisas Econômicas (IPE), 1986, p.103-155.

SLENES, Robert W. Na Senzala, Uma Flor. Esperanças e recordações na formação da família escrava. Brasil sudeste, século XIX. Rio de Janeiro: Nova Fronteira, 1999.

SLENES, Robert. The demography and economics of Brazilian Slavery, 1850-1888. Tese de Ph. D. Standford University, 1976.

SOARES, Mariza de Carvalho. Devotos da Cor. Identidade étnica, religiosidade e escravidão no Rio de Janeiro, século XVIII. Rio de Janeiro: Civilização Brasileira, 2000.

SODRÉ, Nelson Werneck. A História da Imprensa no Brasil. Rio de Janeiro: Civilização Brasileira, 1966.

SOUZA, Laura de Mello e. O Diabo e a Terra de Santa Cruz. Feitiçaria e Religiosidade Popular no Brasil Colonial. São Paulo: Companhia das Letras, 1986.

SOUZA, Laura de Melo e. Os Desclassificados do Ouro. Rio de Janeiro: Graal, 1982.

STOLCKE, Verena e HALL, Michael M. A introdução do trabalho livre nas fazendas de café de São Paulo. Revista Brasileira de História, São Paulo, 3 (6): 80-120, set. 1983.

THOMPSON, E. P. A Formação da Classe Operária Inglesa. Rio de Janeiro: Paz e Terra, 1987. 3 vols.

VAINFAS, Ronaldo (dir.). Dicionário do Brasil Colonial. 1500-1808. Rio de Janeiro: Objetiva, 2000.

VERGOLINO-HENRY, Anaíza; FIGUEIREDO, Arthur Napoleão. A Presença Africana na Amazônia Colonial: uma notícia histórica. Belém: Arquivo Público do Pará, 1990.

VERISSIMO, José. Estudos Amazônicos. Belém: Universidade Federal do Pará, 1970.

VIEIRA, David Gueiros. O Protestantismo, a Maçonaria e a Questão Religiosa no Brasil. 2a. ed., Brasília: Editora UNB, s.d.

VISCONDE DE INDAIATUBA. Memorandum sobre o início de colonização da Fazenda "Sete Quedas", no município de Campinas, em 1852 pelo... In: Monografia Histórica do Município de Campinas. Rio de Janeiro, 1952.

Wanderley Guilherme dos. Ordem Burguesa e Liberalismo Político. São Paulo: Duas Cidades, 1978. 
WEINSTEIN, Barbara. A Borracha na Amazônia: Expansão e Decadência (18501920). Trad. de Lólio Lourenço de Oliveira. São Paulo: Hucitec-Edusp, 1993.

WILLIAMS, Eric. Capitalismo e Escravidão. Trad. Carlos Nayfeld. Rio de Janeiro: Americana, 1975. 